San Jose State University

SJSU ScholarWorks

Master's Theses

Master's Theses and Graduate Research

1999

\title{
Geologic properties of the Cleveland Corral Landslide, Riverton, California
}

Nathan Berube

San Jose State University

Follow this and additional works at: https://scholarworks.sjsu.edu/etd_theses

\section{Recommended Citation}

Berube, Nathan, "Geologic properties of the Cleveland Corral Landslide, Riverton, California" (1999).

Master's Theses. 1861.

DOI: https://doi.org/10.31979/etd.q6e8-85uj

https://scholarworks.sjsu.edu/etd_theses/1861

This Thesis is brought to you for free and open access by the Master's Theses and Graduate Research at SJSU ScholarWorks. It has been accepted for inclusion in Master's Theses by an authorized administrator of SJSU ScholarWorks. For more information, please contact scholarworks@sjsu.edu. 


\section{INFORMATION TO USERS}

This manuscript has been reproduced from the microfilm master. UMI films the text directly from the original or copy submitted. Thus, some thesis and dissertation copies are in typewriter face, while others may be from any type of computer printer.

The quality of this reproduction is dependent upon the quality of the copy submitted. Broken or indistinct print, colored or poor quality illustrations and photographs, print bleedthrough, substandard margins, and improper alignment can adversely affect reproduction.

In the unlikely event that the author did not send UMI a complete manuscript and there are missing pages, these will be noted. Also, if unauthorized copyright material had to be removed, a note will indicate the deletion.

Oversize materials (e.g., maps, drawings, charts) are reproduced by sectioning the original, beginning at the upper left-hand corner and continuing from left to right in equal sections with small overlaps. Each original is also photographed in one exposure and is included in reduced form at the back of the book.

Photographs included in the original manuscript have been reproduced xerographically in this copy. Higher quality $6^{n} \times 9^{n}$ black and white photographic prints are available for any photographs or illustrations appearing in this copy for an additional charge. Contact UMI directly to order.

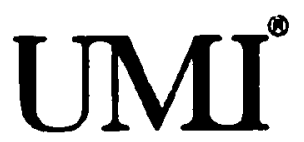

Bell \& Howell Information and Learning 300 North Zeeb Road, Ann Arbor, MI 48106-1346 USA 800-521-0600 



\title{
GEOLOGIC PROPERTIES OF THE
}

\section{CLEVELAND CORRAL LANDSLIDE, RIVERTON, CALIFORNIA}

\author{
A Thesis \\ Presented to \\ The Faculty of the Department of Geology \\ San Jose State University \\ In Partial Fulfillment \\ of the Requirements for the Degree \\ Master of Science
}

by

Nathan Berube

August 1999 
UMI Number: 1396162

UMI Microform 1396162

Copyright 1999, by UMI Company. All rights reserved.

This microform edition is protected against unauthorized copying under Title 17, United States Code.

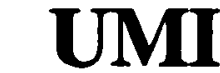

300 North Zeeb Road

Ann Arbor, MI 48103 
(O)1999

Nathan E. Berube

ALL RIGHTS RESERVED 


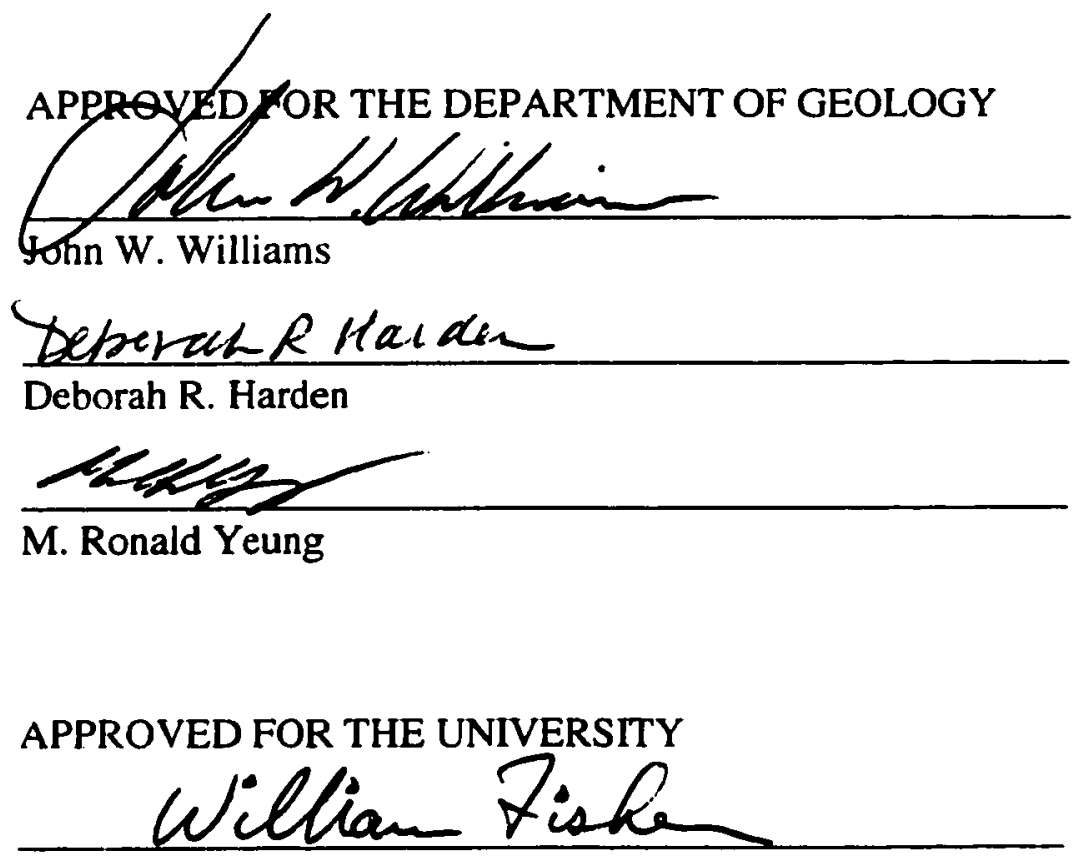




\section{ABSTRACT \\ GEOLOGIC PROPERTIES OF THE CLEVELAND CORRAL LANDSLIDE, RIVERTON, CALIFORNIA \\ By Nathan Berube}

The Cleveland Corral landslide is a slow moving, complex debris slide-debris flow located $2.0 \mathrm{~km}$ east of Riverton, California in the Highway 50 landslide corridor. This study was undertaken to identify and characterize geologic factors such as lithologic contacts, foliation, and ground water seepage, which contributed to the accumulation of ground water and ultimately reduced slope stability. The Cleveland Corral landslide consists of three separate sections with unique geologic properties. After significant precipitation ceased, ground water seepage to the lower sections of the slide maintained high pore pressures and a reduced Factor of Safety (FOS). With elevated pore pressures and a reduced FOS, subsequent minor precipitation events initiated slope failures. Once the slide was in motion, ground water seepage sustained or accelerated movement. Results derived from calculations and simple computer models produced FOS values that were in general agreement with field observations and monitoring data. 


\section{ACKNOWLEDGMENTS}

The author gratefully acknowledges the input and assistance provided by numerous individuals over the past two years. Professors John Williams, Debbie Harden, and Ron Yeung provided constant encouragement and many hours of much needed technical review of the research and many drafts of this thesis.

Special thanks go to Anne Boyd of the U.S. Forest Service, Placerville. Anne not only introduced me to the site, but also greatly assisted in this study by providing everything from critical background information and notice of important events at the site, to acquiring campground access the many nights spent in the field. Mark Reid of the U.S. Geological Survey, Menlo Park, provided valuable technical assistance with monitoring data and high-resolution mapping of the site. Rob Williams of the USGS, Golden, Colorado was instrumental in developing the geophysical aspect of this study. The research was also greatly assisted by site-specific information provided by Josh Roering (U.C. Berkeley), David Jones (U.C. Berkeley), Dave Wagner and Tom Spittler of California Division of Mines and Geology, and Roy Bibbens (Caltrans).

Finally I thank my wife, Colleen, for putting up with the long nights, early mornings, and lost weekends, and for her overall patient support of my academic endeavors. 


\section{TABLE OF CONTENTS}

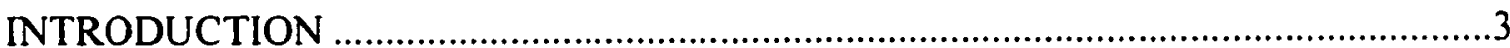

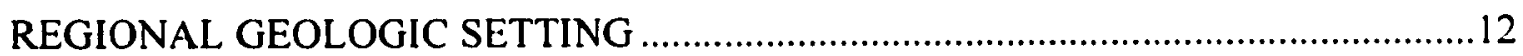

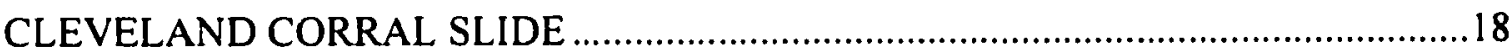

General Description................................................. 18

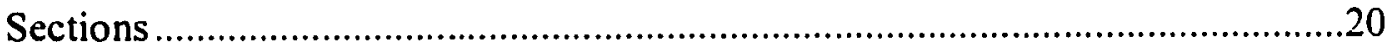

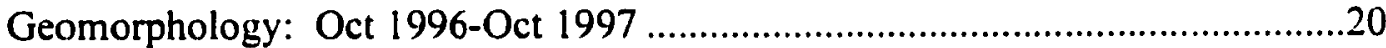

Geomorphic Features of the Upper Section in June 1997 .....................20

Geomorphic features of the Middle Section in June 1997.....................27

Geomorphic Features of the Lower Section in June 1997 .......................33

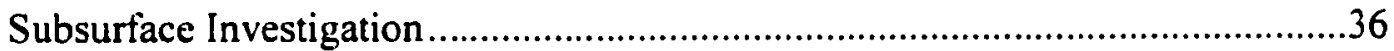

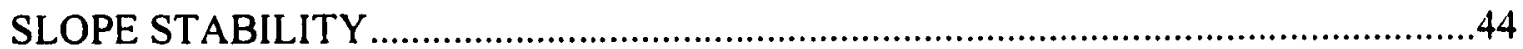

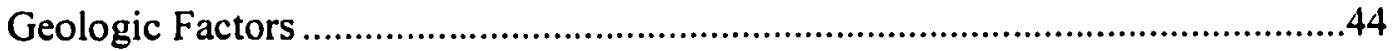

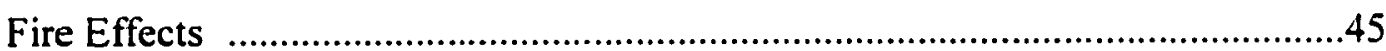

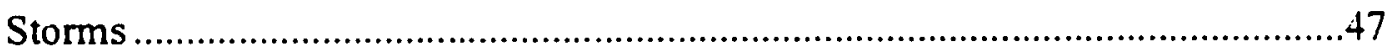

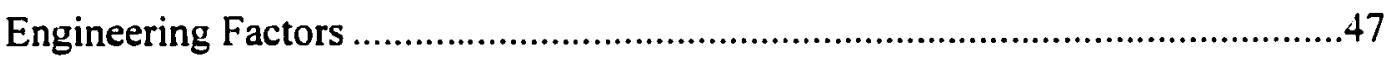

Cleveland Corral Landslide Activity: Jan-Apr 1998 .....................................51

Morphology of the Upper Section During Winter and Spring 1998.....................51

Morphology of the Middle Section During Winter and Spring of $1998 \ldots \ldots \ldots \ldots . . . .60$

Morphology of the Lower Section During Winter and Spring of $1998 \ldots \ldots \ldots \ldots \ldots . . .61$

LIMIT EQUILIBRIUM ANAL YSIS ..........................................................68

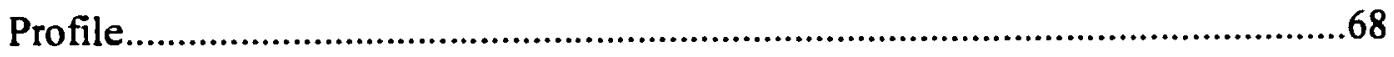


Angle of Friction and Cohesion.......................................................................69

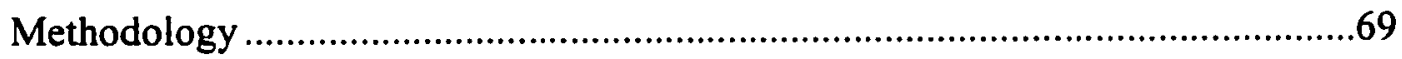

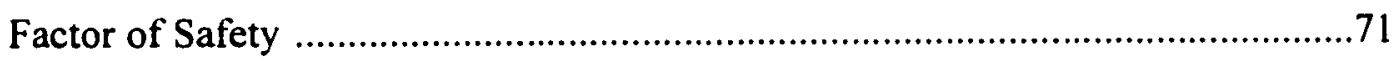

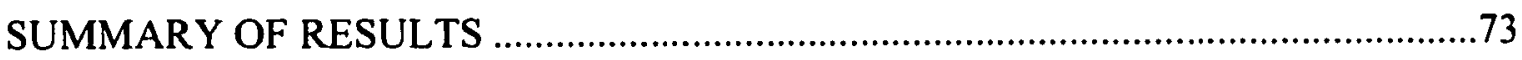

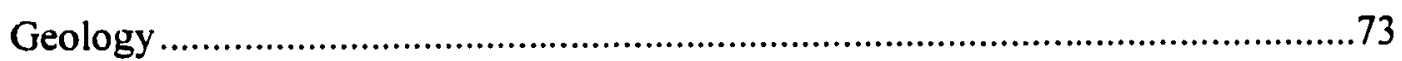

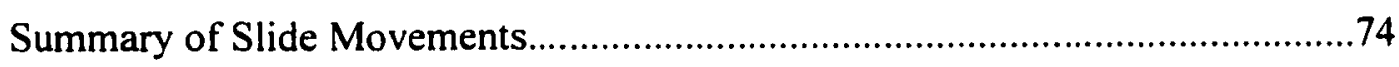

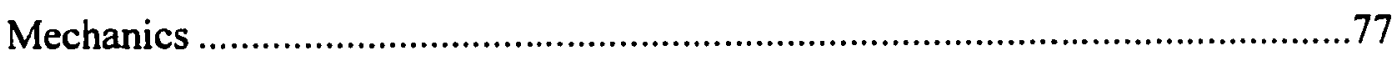

Limit Equilibrium Analysis ............................................................................81

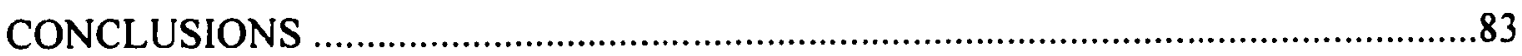

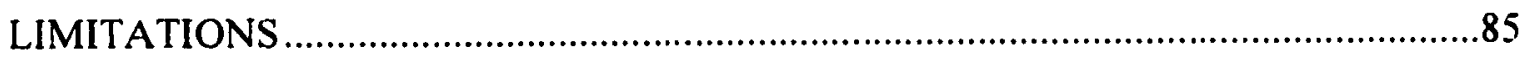

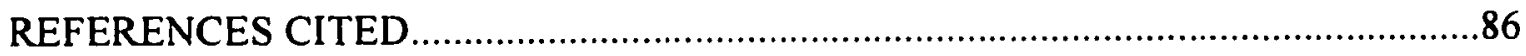

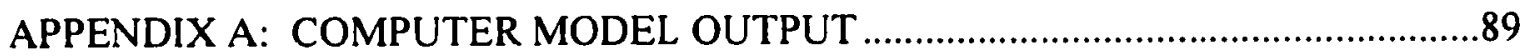

APPENDIX B: INFINITE SLOPE MODEL OUTPUT ...............................................111

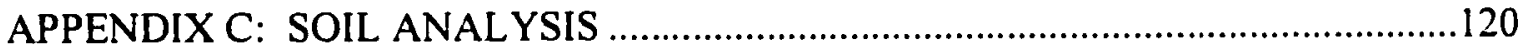




\section{LIST OF ILLUSTRATIONS}

Figure Page

1. Location of the Cleveland Corral Landslide.......................................................

2. Oblique Aerial Photograph of Cleveland Corral Landslide Annotated with Major Geomorphic Landslide Features. ............................................................6

3. Cleveland Corral 8/96-2/97 Vector Map..........................................................

4. USGS Monitoring Equipment Installed at the Cleveland Corral Middle Section in March 1997.........................................................................9

5. Caltrans Mitigation of Cleveland Corral Upper Section. ................................11

6. Regional Geology of the Cleveland Corral Landslide Area............................14

7. Structural Relationship Between Cleveland Corral Landslide and the Mill Creek Landslide............................................................................ 16

8. Photo of Heterogenous Blocky Rock Debris in Gullies at Cleveland Corral..17

9. Oblique Aerial Photo Showing the Outline, Length and Width of Cleveland Corral.

10. Oblique Aerial Photo Showing the Locations of Cleveland Corral Sections, Seismic Survey Lines, and Borings .

11. Line Drawing of the Major Geomorphic Features of Cleveland Corral Landslide. . .22

12. Photo of the Head Scarp of Upper Section. .23

13. Photo of the Upper Section Head Scarp and Minor Scarp.................................23

14. Photo of the East to West View of Upper Section..............................................24

15. Photo of the West to East View of the Upper Section.....................................24

16. Photo of the Secondary Scarp in the Upper Section........................................25

17. Photo of the Dip Slip Striations along the North East Margin of the Upper Section 
18. Photo of the Talus Pile 10 Meters South West of Upper Section

Toe Bulge.

19. Photo of a Graben Located on the Upper West Margin

of the Middle Section.

20. Photo of Mass Wasting Along the Upper West Margin of

the Middle Section.

21. Line Drawing of the Major Geomorphic Features of the Middle and Lower

Sections of the Cleveland Corral Landslide.

22. Photo of the Stair Step Topography Throughout the Middle Section.

23. Photo of the East Margin of the Lower Section.

24. Photo of Trees Toppled by the Downslope Movement of the Lower Section Toe Bulge.

25. Provisional USGS Seismic Results Showing Depth of Colluvium and the Nature of the Bedrock/Colluvium Contact in the Upper Section of Cleveland Corral.

26. Provisional USGS Seismic Results of Previous Landslide Material in Upper Section of Cleveland Corral

27. Provisional USGS Seismic Results Showing Depth of Colluvium and Nature of Bedrock/Colluvium in Middle and Lower Sections of Cleveland Corral.

28. Geologic Profile Developed from Boring \#5 in the Upper Section of Cleveland Corral

29. Geologic Profile Developed from Boring \#6 in the Upper Section of Cleveland Corral .42

30. Longitudinal Cross Section of Cleveland Corral Landslide.

31. Photo of Stump Block and Roct Cylinder in the Upper Section of Cleveland Corral Landslide. 
32. Five Phases of a Translational Slide .............................................................48

33. Pacific House Daily Rainfall.....................................................................52

34. Pacific House Monthly Rainfall.....................................................................53

35. Pacific House Monthly Precipitation as a Percent of Yearly Average..............54

36. Photo of Upper Section Gullies. ....................................................................55

37. Photo of Upper Section Tension Cracks. .........................................................55

38. Photo of Upper Section Tension Cracks. .........................................................56

39. Photo of Upper Section Shallow Slope Failure. ………....................................57

40. Photo of the Upper Section East Margin of Shallow Slope Failure................57

41. Photo of Wattles on the Upper Section...................................59

42. Cleveland Corral Middle Section Deep Open Tube Piezometer.....................62

43. Cleveland Corral Middle Section Shallow Pore Pressure..................................63

44. Cleveland Corral Middle Section Deep Pore Pressure. .....................................64

45. Cleveland Corral Middle Section Displacement................................................65

46. Cleveland Corral Lower Section Displacement. .................................................66

47. Photo of Upper Section Head Scarp and Two Minor Scarps............................78

Plate

1. Geologic Properties of the Cleveland Corral Landslide,

Riverton, California............................. pocket

Table

1. FOS from Infinite Slope, Computer Model, and Monitoring Data ........71

2. FOS from PSCTABL and Infinite Slope During Saturated, Wet, and Dry Conditions. . . . . . . . . . . . . . . . . . . . . . . . . . . 


\section{STATEMENT OF PURPOSE}

A detailed study of the factors affecting slope stability at Cleveland Corral was performed between April 1997 and April 1998. Cleveland Corral is within a 24 km (15 mile) portion of the South Fork of the American River known as the Highway 50 landslide corridor (Fig. 1). The objective of the investigation was to determine the geologic and engineering properties of Cleveland Corral to better understand the response of the slope to above average rainfall. This study allowed for the examination of: 1) the complex nature of the Cleveland Corral landslide; 2) whether a geologic contact between two bedrock units affected slope stability; 3) whether foliation and schistosity affect slope stability; 4) how above average rainfall affects the hydrogeologic properties and ultimately the sensitivity of the Cleveland Corral landslide; and 5) whether valid models can be created to accurately characterize and predict the failure of a complex heterogeneous slope.

In order to assess the nature of the Cleveland Corral landslide, it was necessary to create a model of the slope. The basis of this model was a geologic profile composed of the topographic surface, a layer of colluvium, and a bedrock contact assumed to be the failure surface. Hydrogeologic and soil strength properties were added to the model as inputs to infinite slope equations and a limit equilibrium computer analysis used to calculate the Factor of Safety (FOS) of Cleveland Corral. 

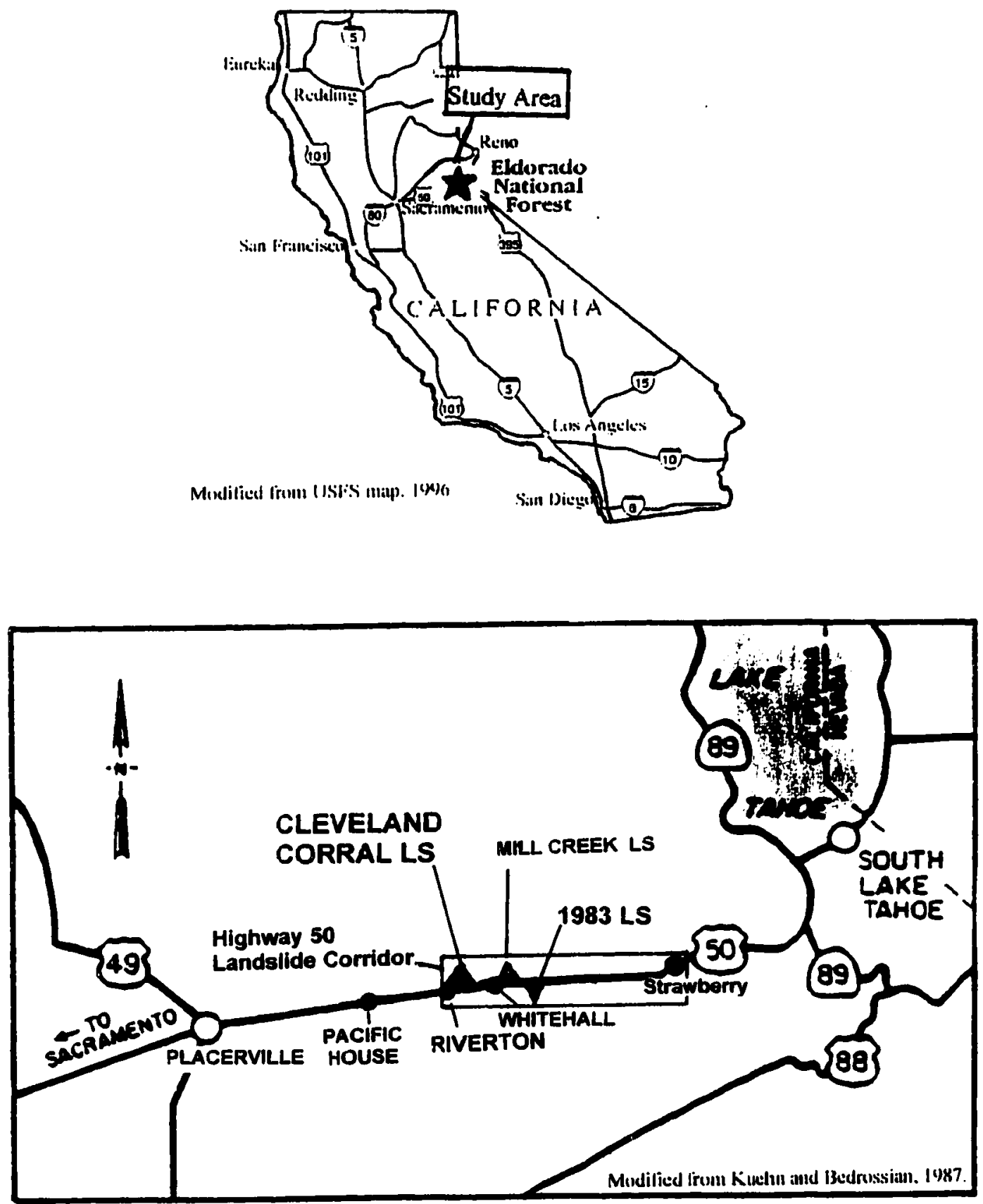

Figure I. Location of the Cleveland Corral landslide in relation to the Highway 50 landslide corridor, and of two recent catastrophic landslides. 


\section{INTRODUCTION}

The Highway 50 landslide corridor is located within the inner gorge of the South Fork of the American River and includes the towns of Riverton and Whitehall (Fig. 1). It is a $915-1280 \mathrm{~m}$ deep, steep-walled canyon, carved by the South Fork of the American River during the past 4-5 million years in response to episodic uplift and westward tilting of the Sierra Nevada Mountains, which are to the east of Cleveland Corral. The northsouth trending range rises to $3050 \mathrm{~m}$ and was extensively glaciated. Pleistocene glaciers stripped away most of the weathered granitic rock in the higher elevations, and landslide failures there are generally steep narrow rock avalanches. This is not the case along the non-glaciated Highway 50 landslide corridor, where large masses of weathered granitic material and quartz-mica schist characterize the inner gorge of the South Fork of the American River Canyon (Wagner and Spittler, 1997). These deeply weathered materials have produced a deep layer of colluvium, which under the proper conditions become unstable. The inner gorge has more than 600 slope failures between the towns of Riverton and Strawberry (Fig. 1). More than 50 of these landslides moved during the winter of 1996-97, and 24 landslides, at the time of this writing, are a threat to Highway 50 (Wagner and Spittler, 1997).

A particularly hot forest fire in September, 1992 destroyed 25,000 acres of vegetative cover on the heavily forested slopes of the inner gorge including Cleveland Corral and Whitehall (A. Boyd, El Dorado National Forest, unpub. data, 1997). Vegetation plays an important role in slope stability by physically strengthening the nearsurface soil profile and slowing surface runoff. Evapotranspiration and interception 
lower the antecedent water volume in the soil profile, thereby reducing the pore pressure at the failure surface of the slide.

Considering that the slopes of Cleveland Corral received 225 to 325 percent of average precipitation during the winters of 1997 and 1998, they may have become unstable even if the 1992 forest fire had not occurred. The U.S. Forest Service (A. Boyd, El Dorado National Forest, unpub. data, 1997) reported that many slides occurred during and after the January 1997 deluge in forested areas as well as burned areas along Highway 50.

In May 1996, a USFS geologist (Anne Boyd) first identified indications that the steep colluvium of the noriicrn slope in the gorge was becoming unstable. Upon further investigation, she found that the slopes on the north side of Highway 50, from Riverton to Whitehall (Fig. 1), displayed geomorphic indications of active slope movement. A letter stating the potential for landslides was distributed to the Whitehall and Riverton residents in May, 1996 (Boyd, 1996). At 11:20 PM on January 24, 1997, after almost a month of intense rainfall, the slopes above Whitehall failed catastrophically. Labeled the Mill Creek slide, it was classified as a debris slide-debris flow composed of very wet sandy colluvium (Sydnor, 1997). The initial movement near the crest is believed to have been a translational debris slide, changing to a debris flow over the steeper lower slopes (Sydnor, 1997). The landslide stopped after burying Highway 50 with mud and debris in a swath about $244 \mathrm{~m}$ wide. The toe of the slide continued up the opposite riverbank vertically for $15 \mathrm{~m}$, temporarily damming the South Fork of the American River. The river breached the landslide within 2 hours, causing local downstream flooding and damage to vacation cabins, private bridges, and segments of the Highway 50 embankment (Sydnor, 1997). The subsequent road closure lasted 27 days. The loss of revenue to South Lake Tahoe 
during peak ski season and local businesses all along Highway 50 prompted the dedicated attention of state and federal transportation agencies. The direct cost of road repair was $\$ 5$ million, and total indirect costs due to lost revenue were estimated at approximately $\$ 55$ million (A. Boyd, El Dorado National Forest, unpub. data, 1997). An earlier catastrophic slide occurred in October 1983. This landslide, named the 1983 Landslide (Fig. 1), closed Highway 50 for 87 days and accrued $\$ 33$ million in direct and indirect costs (Keuhn and Bedrossian, 1987).

The Cleveland Corral slide is located $2.0 \mathrm{~km}$ west of the Mill Creek slide. Its topography, site geology and structure are all similar to Mill Creek's. It also displays numerous geomorphic indications of recent slope failure (Fig. 2) and was subjected to the same meteorological conditions as the Mill Creek slide. Josh Roering, a Berkeley Ph.D. candidate, conducted topographic surveys of Cleveland Corral in the fall of 1996 and again in February 1997. During the same time period that the Mill Creek slide failed catastrophically, Roering found that the upper reaches of the Cleveland Corral site had maximum surface displacement of $12 \mathrm{~m}$ before stopping after the rains ceased in March 1997 (Fig. 3).

As a result of the Mill Creek slide, several agencies began or intensified investigations of the Highway 50 slide corridor. Roering's survey, combined with the USFS findings and several other observations, provided insight to the extent of the landslide threat to Highway 50. In response to this threat, California Division of Geology and Mines (CDM\&G) geologists prepared maps of the geology and landslides along 24 km of Highway 50 known as the Highway 50 landslide corridor. Numerous landslides, including Cleveland Corral, were identified and categorized as having a high potential to impact Highway 50 (Wagner and Spittler, 1997). 


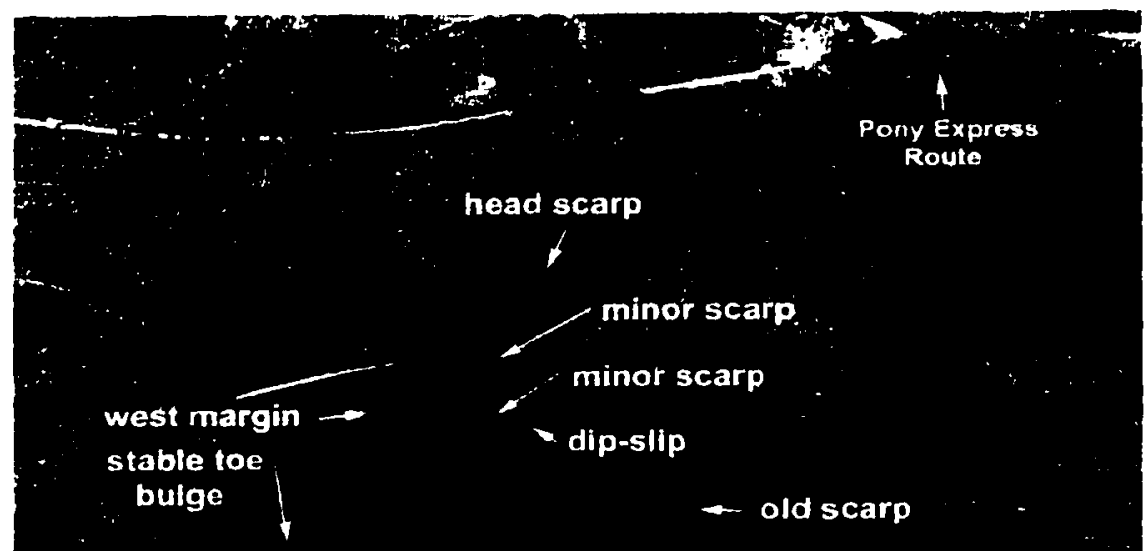

talys pile

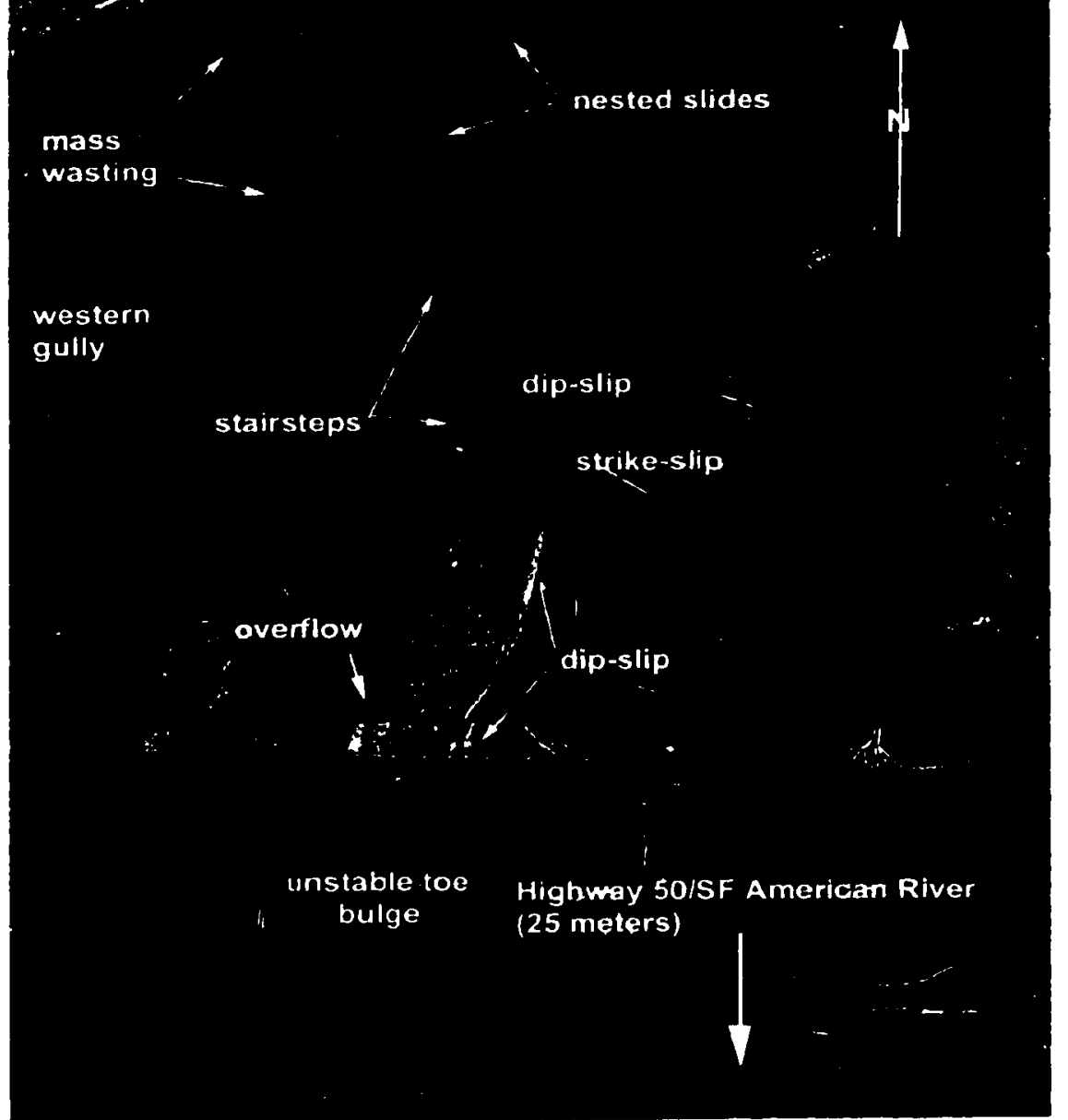

Figure 2. Oblique aerial photo showing the Cleveland Corral landslide annotated with major geomorphic features. Photo taken 3/21/97 for Caltrans. 


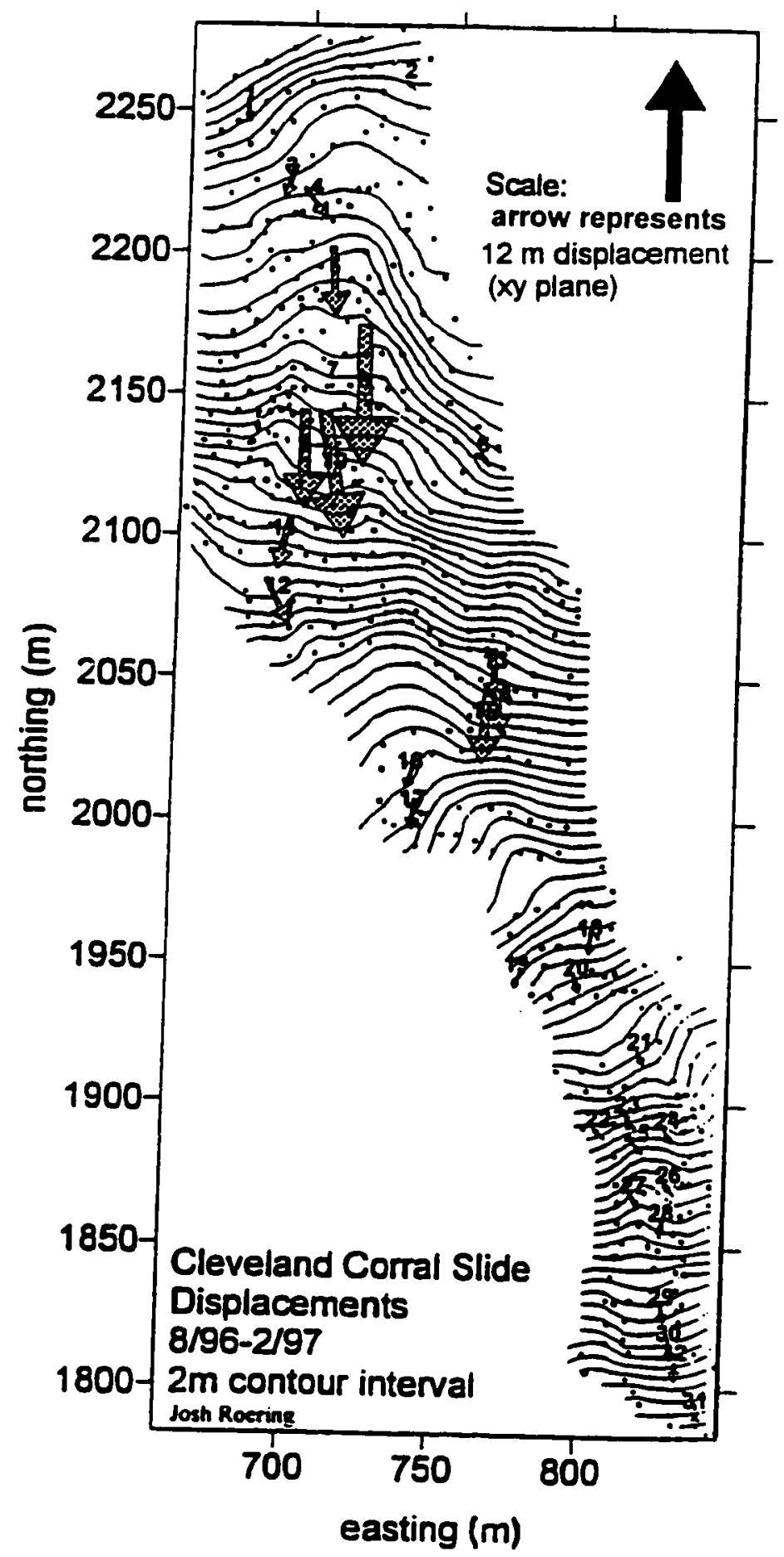

Figure 3. Cleveland Corral Landslide Vector Map. Arrows show direction and distance of slope movement between 8/96 and 2/97 (J. Roering, unpub. data, 1997). 
Cleveland Corral and other unstable sites in the Highway 50 landslide corridor have since been instrumented by Caltrans, U.S. Geological Survey (USGS), and the USFS, with rain gages, surface extensometers, down-hole extensometers, piezometers, shallow and deep pore water pressure monitors, and geophones. Surface extensometers are monitored "real-time", via the Internet, and are connected to an automated paging program to alert authorities in the event of any significant surface movement (Fig. 4). Aerial photo targets were surveyed in July 1997 by the USFS for subsequent low-altitude aerial photos. These photos were digitized by the USGS and the resulting maps, of 1-m contour interval, were used as the base maps for detailed surface mapping by USGS personnel, J. Roering, and the author. Also, the maps can be digitally compared to future aerial photos to produce displacement vector maps. In August 1997, a USGS seismic crew conducted seismic refraction surveys. They recorded $\mathrm{S}$ and $\mathrm{P}$ wave velocities across the upper portion of the site and $\mathrm{P}$ wave velocities along the lower third of the site.

Borings were made to facilitate the installation of additional monitoring equipment in October 1997. Boring logs helped define colluvium characteristics and depth to bedrock (A. Boyd, El Dorado National Forest, unpub. data, 1997); (Platel).

In 1997, landslide mitigation efforts at the site had been restricted to the upper and lower sections because of the limited and difficult access to the remainder of the site. Mitigation included grading of the surface to fill the multitude of open tension cracks. In addition, a two-tiered array of horizontal drains and two stone drains were installed on the top section diverting surface runoff and shallow ground water to a natural drainage 


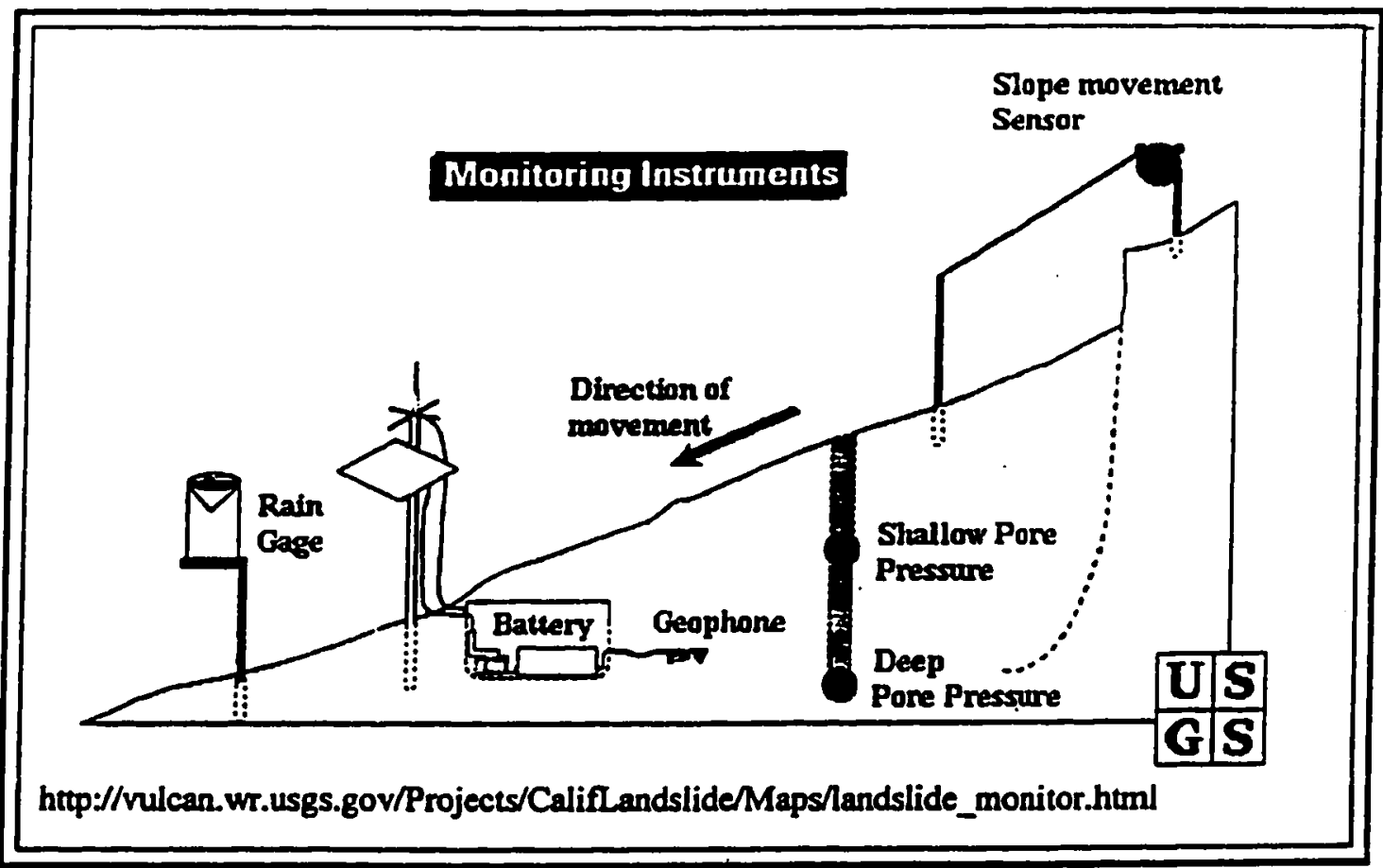

Figure 4. USGS monitoring equipment installed on the middle section of Cleveland Corral in March 1997. Data are transmitted using telemetry and remotely monitored on the website shown above (R. LaHusen, USGS, written commun., 1997). 
beyond the western margin of the slide area (Fig. 5). Straw wattles were placed orthogonal to the slope to slow surface runoff. 


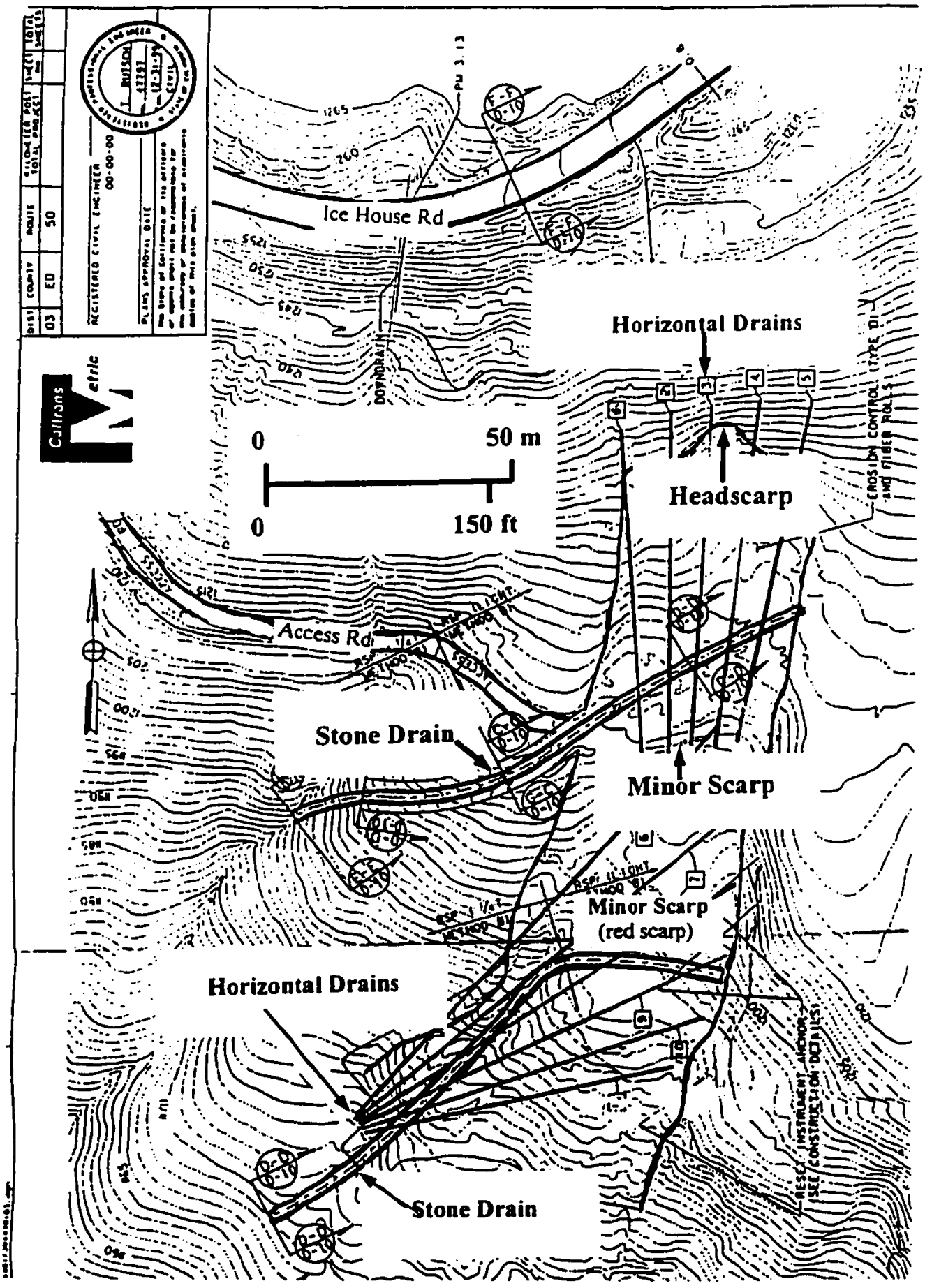

Figure 5. Caltrans mitigation of the Cleveland Corral upper section.

Horizontal drains conveyed ground water from deep (6-7 m) colluvium while stone drains diverted surface runoff and shallow ground water (modified from $T$. Rutsch, Caltrans, unpub. data, 1997). 


\section{REGIONAL GEOLOGIC SETTING}

The Cleveland Corral and Mill Creek slides are located in a steep-sided canyon carved by the South Fork of the American River. Within the drainage of the South Fork. three broad geologic subdivisions of the lower Paleozoic Shoo Fly Complex can be identified. The western belt is composed of slate with minor chert and siliceous shale. The middle belt is composed of interbedded sandstone and slate (flysch). The eastern belt consists mostly of massive quartzite and quartz-mica schist (pKm), with minor amounts of pelitic rock (Jones and others, 1997). Upper Paleozoic and Mesozoic rocks of the Northern Sierra terrane that unconformably overlie the Shoo Fly to the north do not extend south of the Middle Fork of the American River. In addition, subdivisions of the Shoo Fly that have been located north of the 39th parallel have not been recognized within the slide area at $38^{\circ} 46^{\prime}$ north latitude (Jones and others, 1997). The rock units observed in the vicinity of Cleveland Corral belong to the eastern margin of the eastern belt of the Shoo Fly Complex, which also forms the basement for the overlying Northern Sierra Terrane. In the study area, the Shoo Fly is composed of a thick structural assemblage of metamorphosed quartz sandstone.

Granitoid rocks intruded into the Shoo Fly include Jurassic diorite and Cretaceous hornblende biotite granodiorite. The margins of the Jurassic dioritic intrusives are foliated parallel to the foliation in the adjoining quartz-mica schist, reflecting a common syntectonic event. Based on aluminum content and hornblende development, Jones and others (1997) found that the pluton was emplaced at great depth and high temperature, 
metamorphosing the local quartz sandstone into quartz-mica schist. The diorite pluton exposed at the Icehouse Road roadcut, just above the Cleveland Corral slide, is intruded into the Shoo Fly as a sill-like body with a flat lower contact. The contact, as well as the foliation in both the diorite and quartz-mica schist, has been folded into a gently southplunging fold axis that trends SSE (Fig. 6). Younger Cretaceous plutons cut across the structural fabric of the Shoo Fly and the Jurassic diorite, but lack penetrative deformation (Jones and others, 1997).

Geologic mapping of the Cleveland Corral site indicates that the area consists primarily of Cretaceous granitoid rocks of the Sierra Nevada Batholith (Kgr), including deformed diorite and quartz diorite. An isolated exposure of lower Paleozoic quartz-mica schist $(\mathrm{pKm})$ is located between Cleveland Corral and Whitehall (Fig. 1). The eastern and western contacts of $\mathrm{pKm}$ with granitic rocks occur along the Cleveland Corral and Mill Creek slides, respectively (Jones and others, 1997; Wagner and Spittler, 1997). Exposure of $\mathrm{pKm}$ between the Cleveland Corral landslide and the Mill Creek landslide also suggests the presence of an antiformal structure which extends from Cleveland Corral to the east for approximately $2 \mathrm{~km}$.

Above Ice House Road the slopes are strewn with the remnants of the 10 my old Mehrten Formation ( $\mathrm{Tm})$ which is composed of andesitic lahars and other volcanic constituents (Jones and others, 1997); (Fig.6). The Mehrten appears to provide protective cover for the underlying granodiorite and quartz-mica schist. This becomes apparent just above Ice House Road at the head of Cleveland Corral. Here the protective cover has eroded away, exposing the deep colluvial material which covers the granodiorite and 


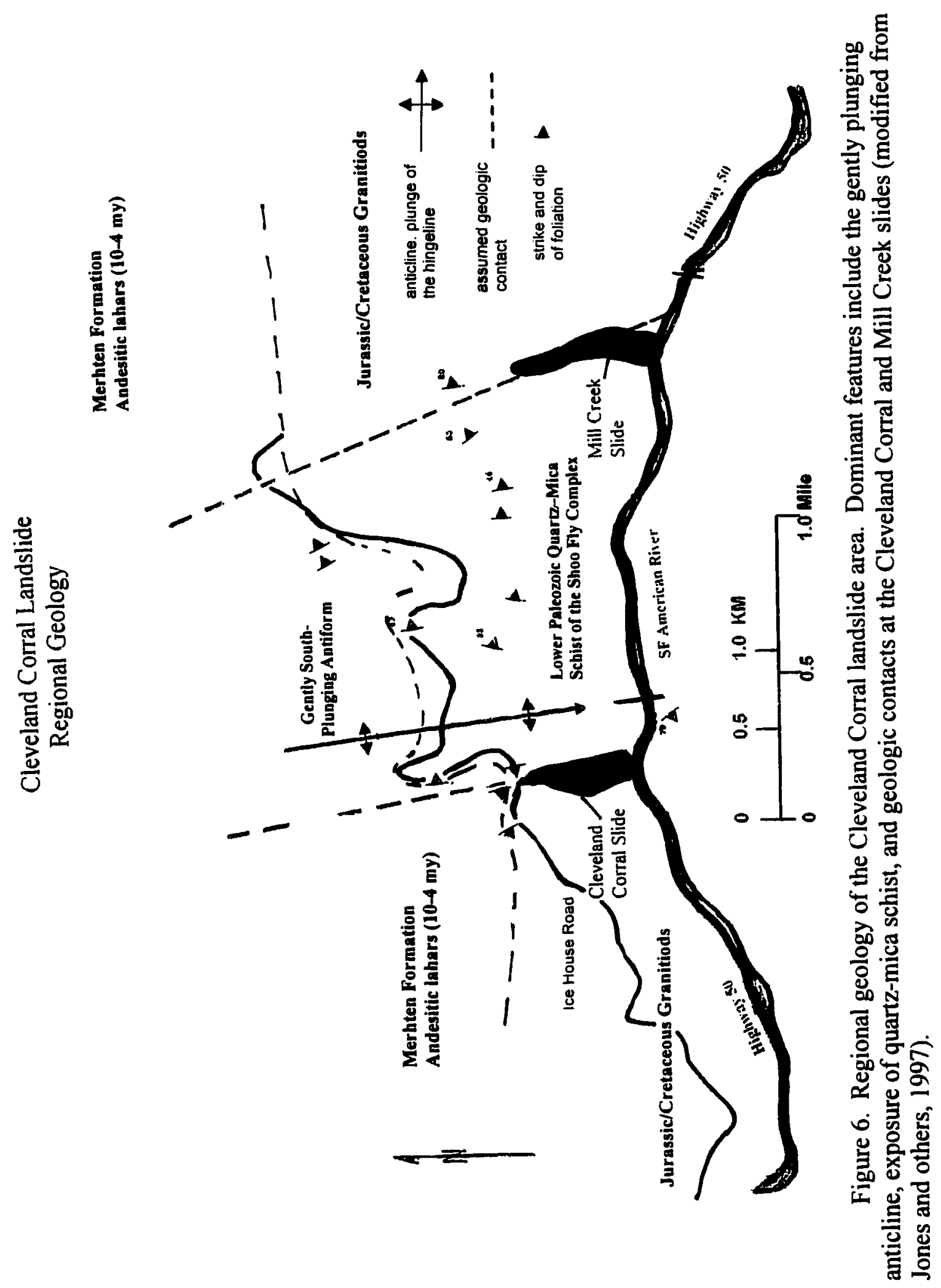


quartz-mica schist. This site is deeply gullied, and shows signs of recent and significant slope failure toward the east of Cleveland Corral. Dark red slide debris from this site has been bladed off the road by Caltrans onto the downhill slope, just above the uppermost head scarp of Cleveland Corral.

At Cleveland Corral the dip of the foliation is parallel or sub-parallel to the natural topography, which provides easy infiltration of precipitation and the development of failure planes in the down-slope direction. This would also provide an inherent tendency for the material to move in a westward direction, down-dip, toward the steep gully past the western margin of the slide (Fig. 7). However, the slide material in the middle section of Cleveland Corral moves to the south, approximately 25 degrees away from the down-dip direction, moving along the eastern margin. This indicates lithologic control provided by the contact between the pKm and the Kgr (Fig. 6).

Rocks at Cleveland Corral are of numerous types, including banded gneiss, granite gneiss, biotite gneiss, quartz-mica schist, gabbro, granodiorite, quartzdiorite, and pegmatite. Abundant and predominantly angular samples are mixed in the washes and exposures, where they range in size from boulders to coarse sand (Fig. 8). Of particular interest, at the upper western margin, is a rocky ridge consisting of gneiss boulders. Their sizes range from $1 \mathrm{~m}$ at the uphill end, to $9 \mathrm{~cm}$ at the downhill end of the ridge. The ridge is approximately $10 \mathrm{~m}$ wide and $28 \mathrm{~m}$ long, and is significant because it apparently buttresses the toe of the upper section of the slide. 


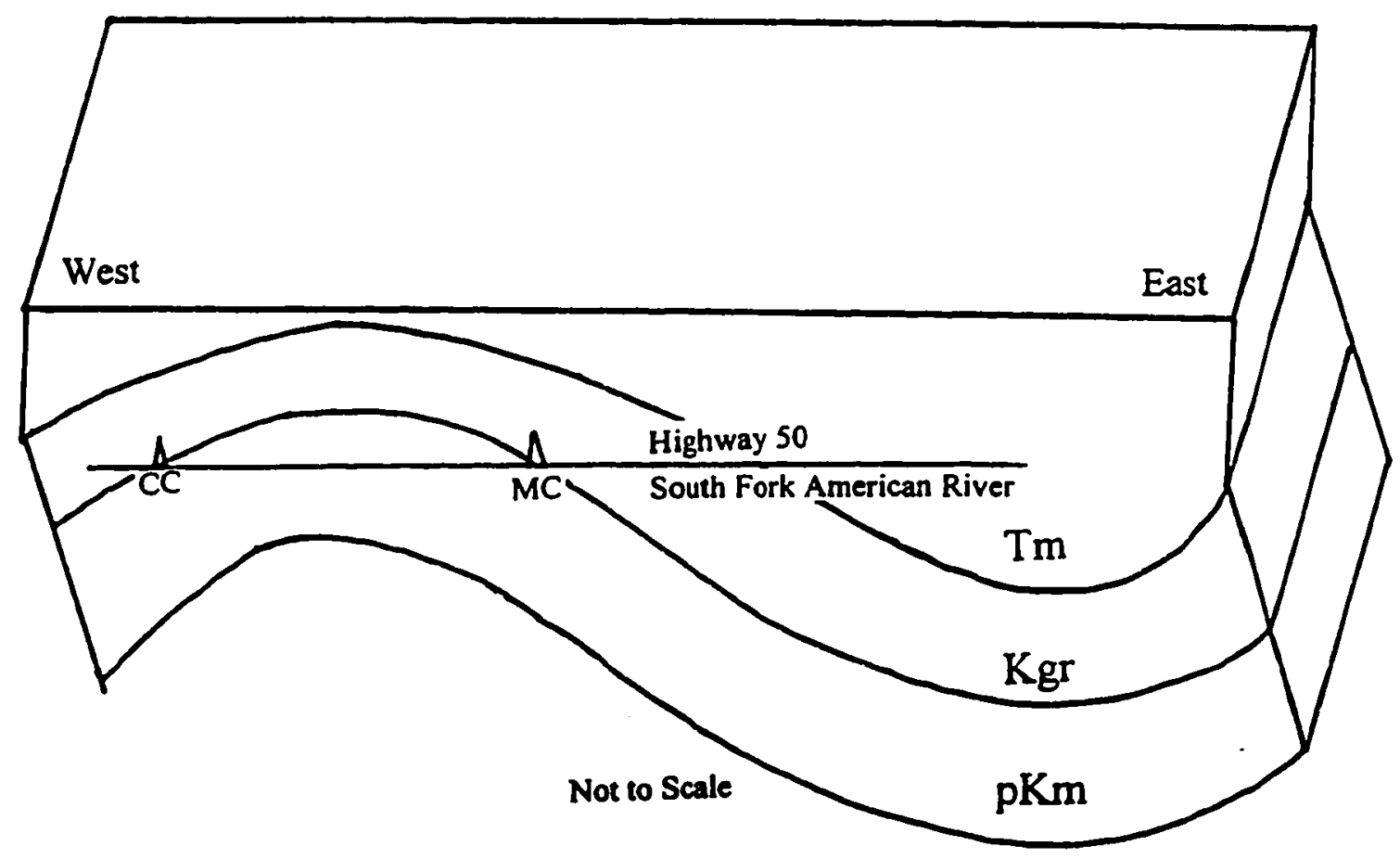

Figure 7. Simplified depiction of the structural relationship of the lower Paleozoic quartz-mica schist $(\mathrm{pKm})$ exposure between the Cleveland Corral (CC) landslide and the Mill Creek (MC) landslide. 


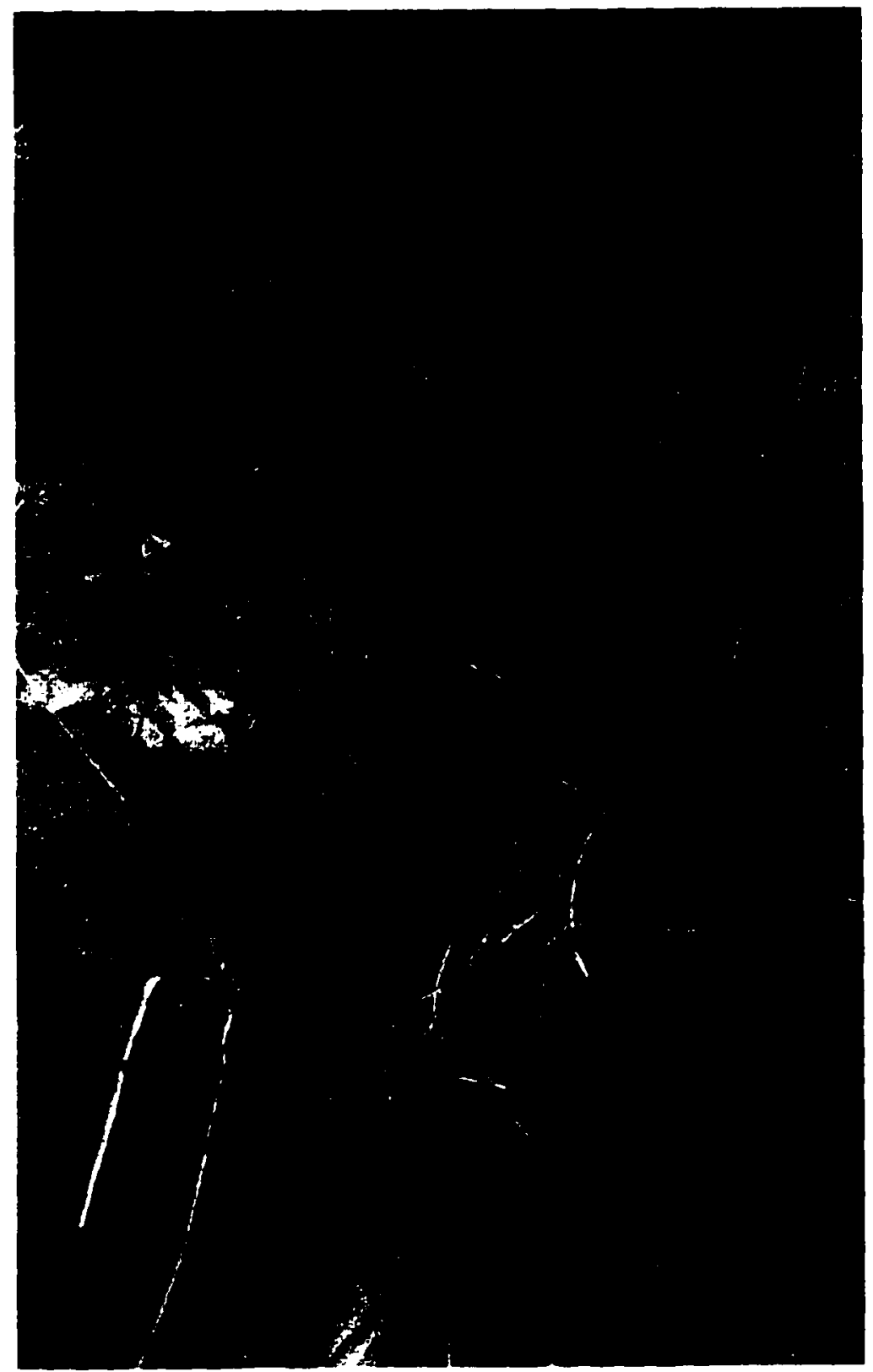

Figure 8. Heterogeneous blocky rock debris found in gullies throughout the Cleveland Corral area. Photo taken 9/6/97. 


\section{CLEVELAND CORRAL SLIDE}

\section{General Description}

The Cleveland Corral landslide, narrower than many other slides in the steep colluvium of the Highway 50 landslide corridor, is $571 \mathrm{~m}$ long, from 11 to $23 \mathrm{~m}$ wide, with an overall slope of 21 degrees (Fig. 9). Well logs and preliminary seismic data indicate colluvium depth of 9-11 m. According to Skempton and Hutchinson (1969) these parameters describe a translational slide- " $\mathrm{Dr} / \mathrm{Lr}$ for translational slides in soils are typically less than 0.1 ", where $\mathrm{Dr}=$ depth of surface of rupture, $\mathrm{Lr}=$ length of surface of rupture. Using a depth to the failure plane of $11 \mathrm{~m}$ based on well logs, Cleveland Corral has a $\mathrm{Dr} / \mathrm{Dl}$ of 0.019 .

The slopes at Cleveland Corral are steep, ranging from 20 to 35 degrees as measured from topographic maps. They are covered with heterogeneous colluvium, consisting of coarse, angular particles ranging in size from silty sand to small boulders. The upper portion of the site is a debris-filled hollow (Fig. 2). Hollows have been identified as locations that accumulated colluvium and therefore, are susceptible to the initiation of landsliding (Dietrich, and others, 1986).

Evidence suggests that Cleveland Corral is a reactivation of an older landslide. The lack of stratification in exposures in and around the site, inconsistent distribution of different colored colluvium observed during on-site drilling, and preliminary seismic surveys of the upper section that show a velocity contrast that could support either one or two layers of colluvium, suggest previous landsliding at the site. Also, coherent sections 


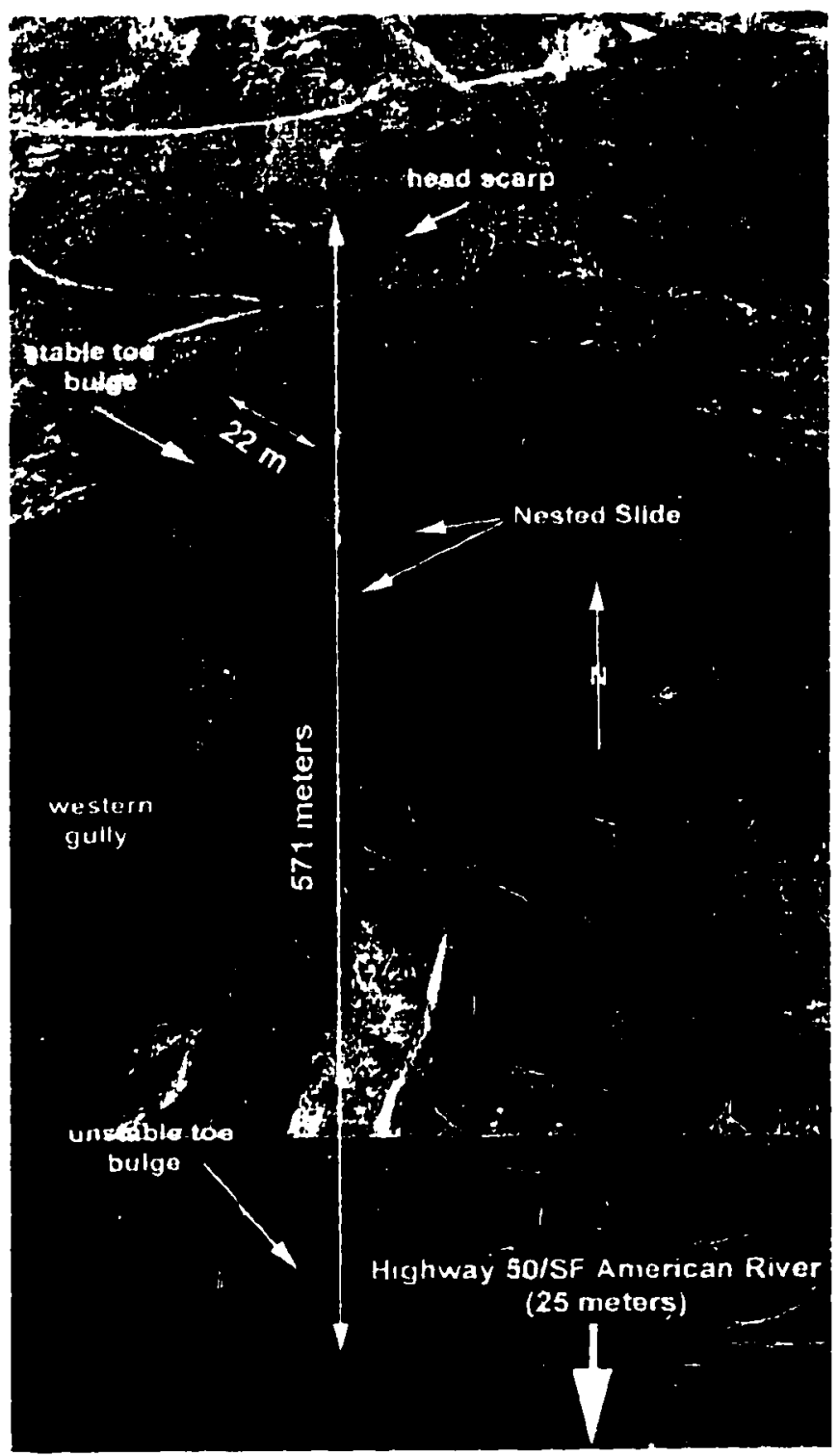

Figure 9. Oblique aerial photo showing the outline, length, and width of the Cleveland Corral landslide. Photo taken 3/21/97 for Caltrans. 
of the Mehrten Formation in and around the site, are most likely to have been transported to the area by previous slide activity (Wagner and Spittler, 1997).

\section{Sections}

On-site mapping of geomorphic features revealed that Cleveland Corral landslide has three distinct sections; upper, middle, and lower (Fig. 10), each of which exhibits recent translational, debris slide characteristics (Fig. 2).

\section{Geomorphology: Oct 1996-Oct 1997}

Geomorphic Features of the Upper Section in June 1997

The upper section is a translational slide with coherent displaced segments in the upper and middle areas, and a very prominent toe bulge at its downslope terminus. The main body of actively sliding colluvium in the upper section is identified by a very disturbed colluvial surface bounded by east and west lateral scarps of $0.3 \mathrm{~m}$ (Fig. 11).

The surface of the upper segment of the slide consists of a gray-brown colluvium at the top, which grades to deep, dark red colluvium towards the bottom. It is bounded by a head scarp just below Ice House Road, and the bottom of the upper section is defined by recognizable thrusts above and to the east of an anomalous talus pile near the western margin of the upper section (Figs. 12-18). The general direction of entire upper slope failure trends SSW toward the gully just beyond the west margin. Striations on the dipslip surface along the eastern margin are shown in Figure 17 and plotted on Plate 1. 


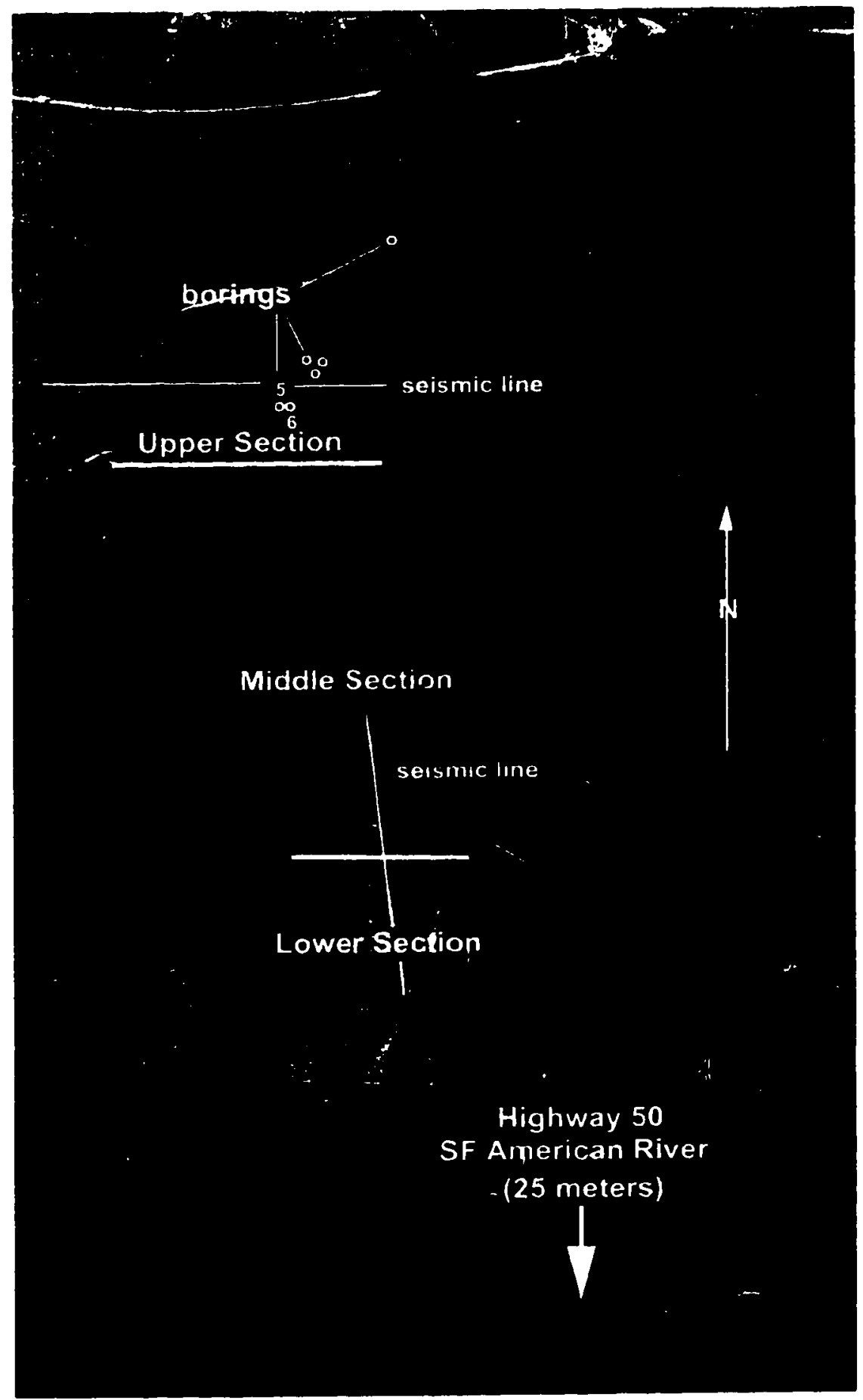

Figure 10. Oblique aerial photo showing the locations of Cleveland Corral sections, seismic lines, and borings. Photo taken 3/21/97 for Caltrans. 

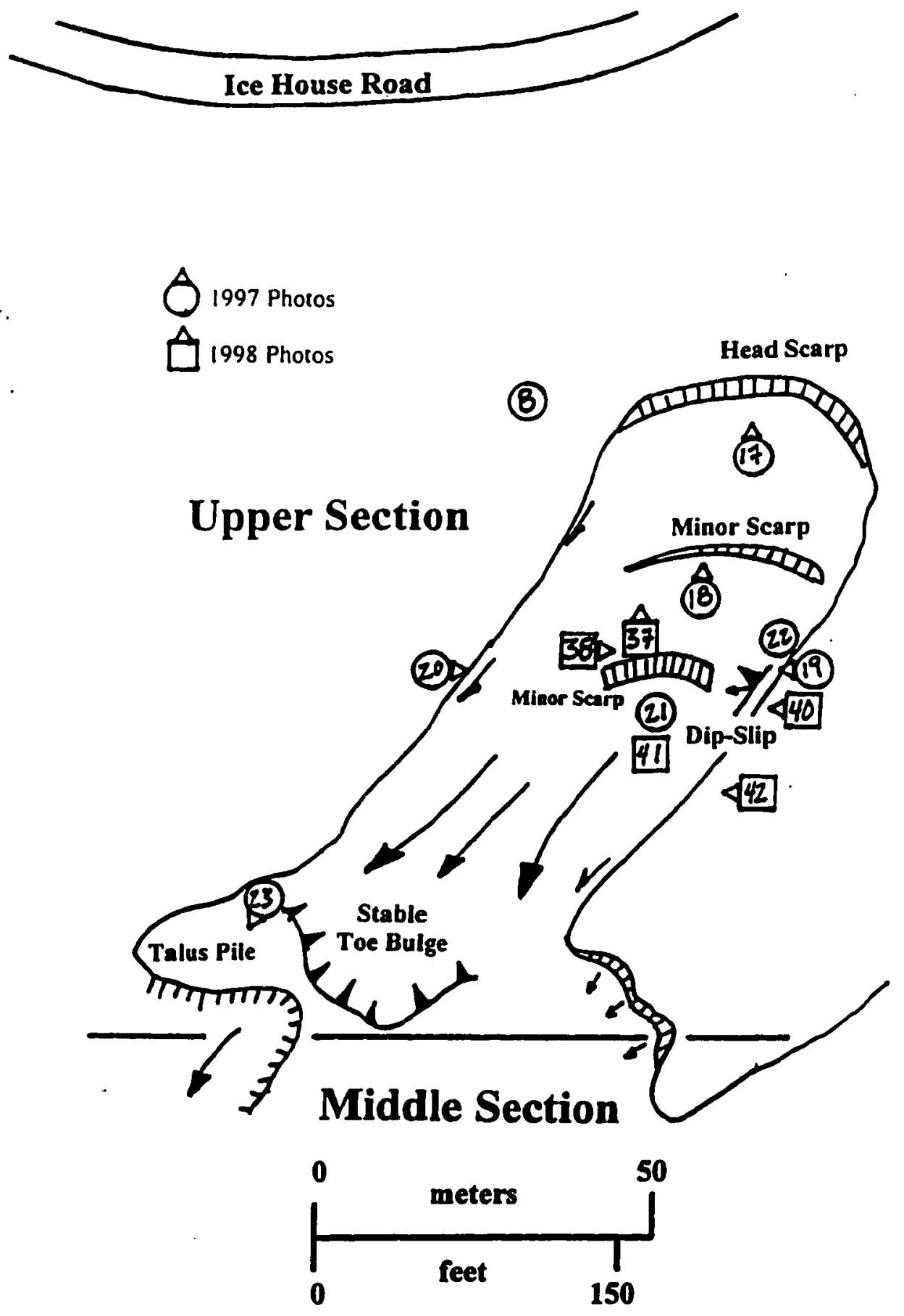

Figure 11. Major geomorphic features of the upper section of the Cleveland Corral landslide. The numbers correspond to figure numbers for photos in the text, showing the location where, and direction in which each photo was taken. 


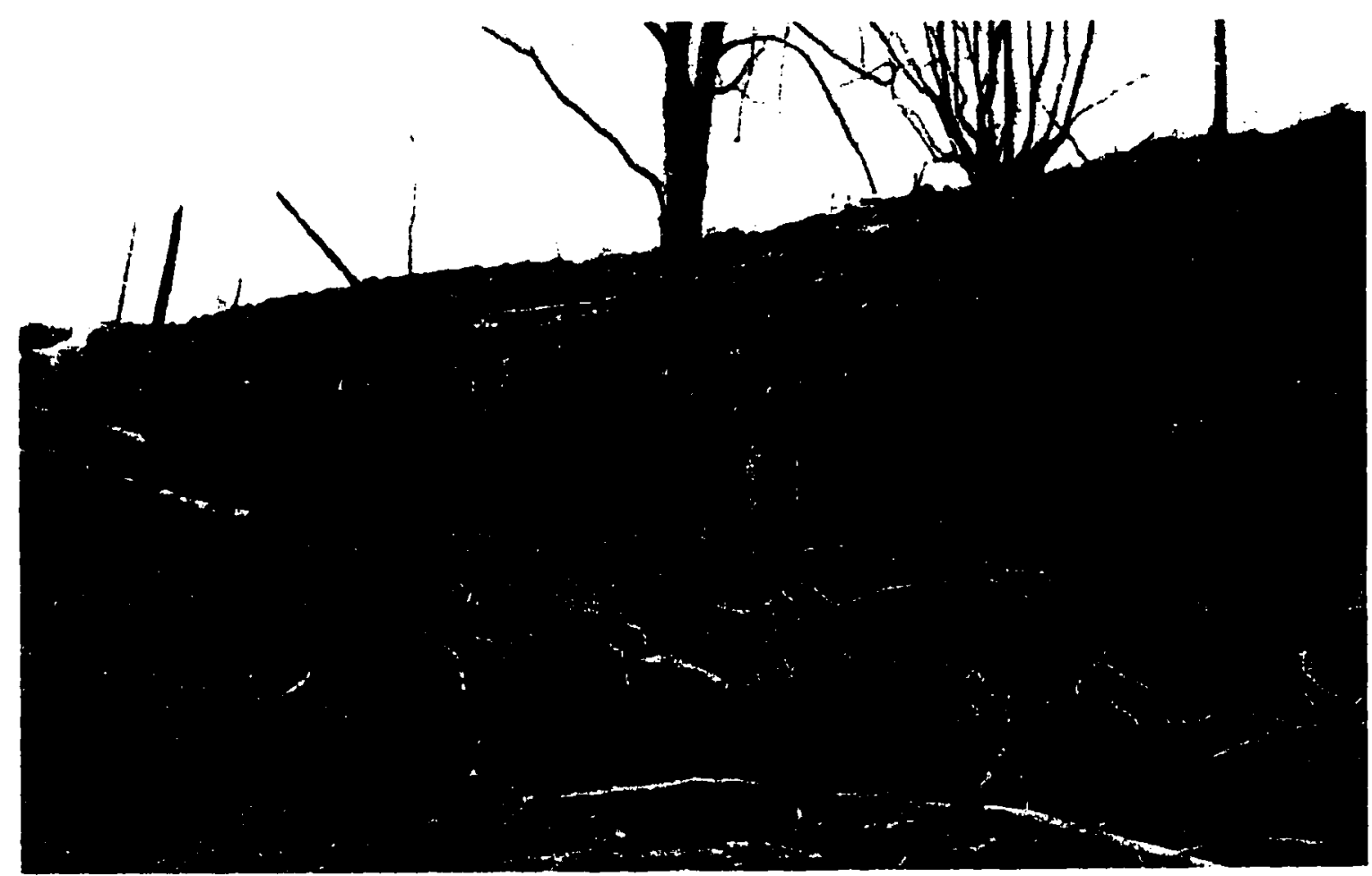

Figure 12. Cleveland Corral landslide head scarp located in the upper section. Photo taken 4/12/97. View to the northwest.

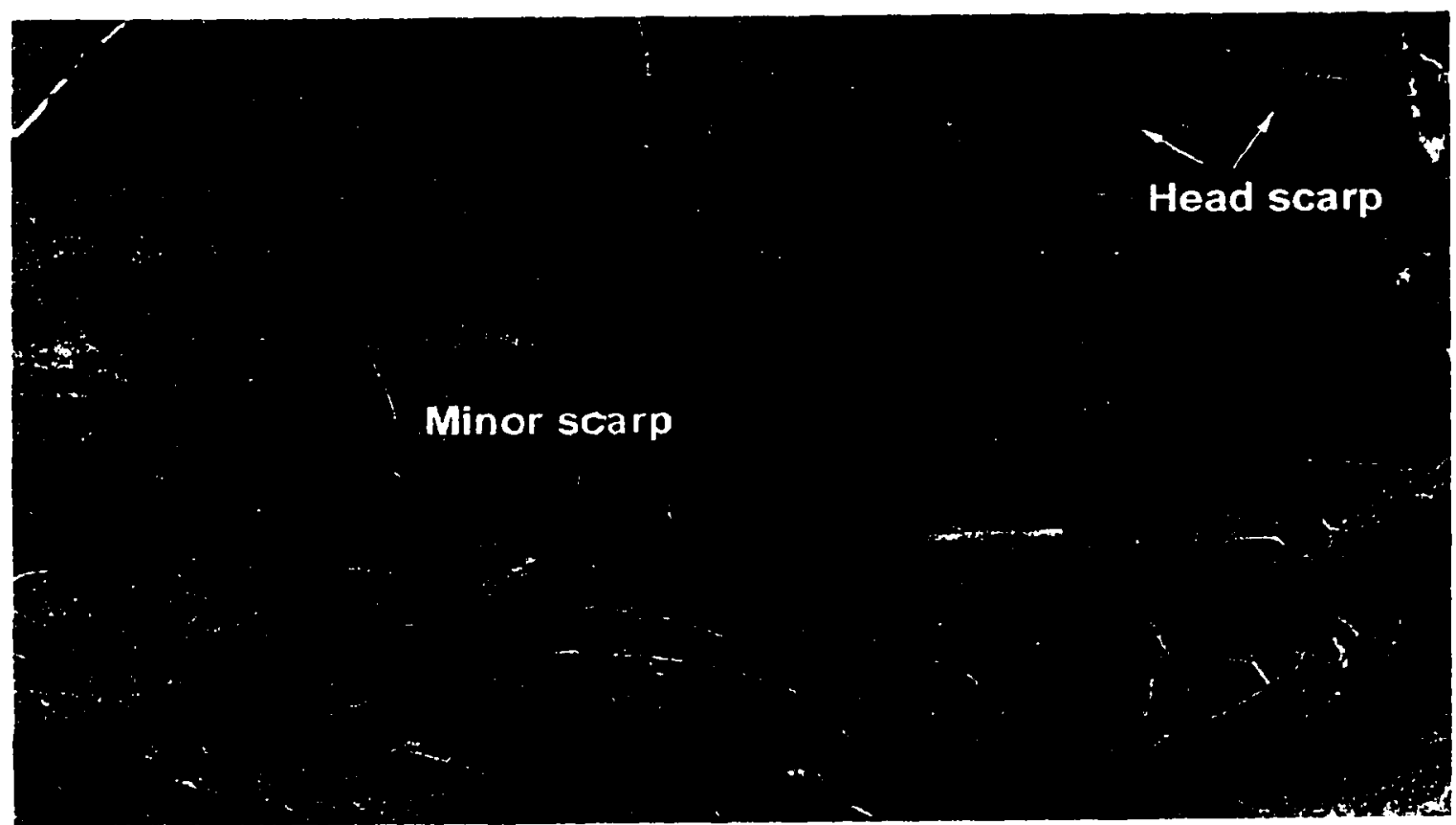

Figure 13. Upper section head scarp and minor scarp. Photo taken 4/12/97. View to the northwest. 


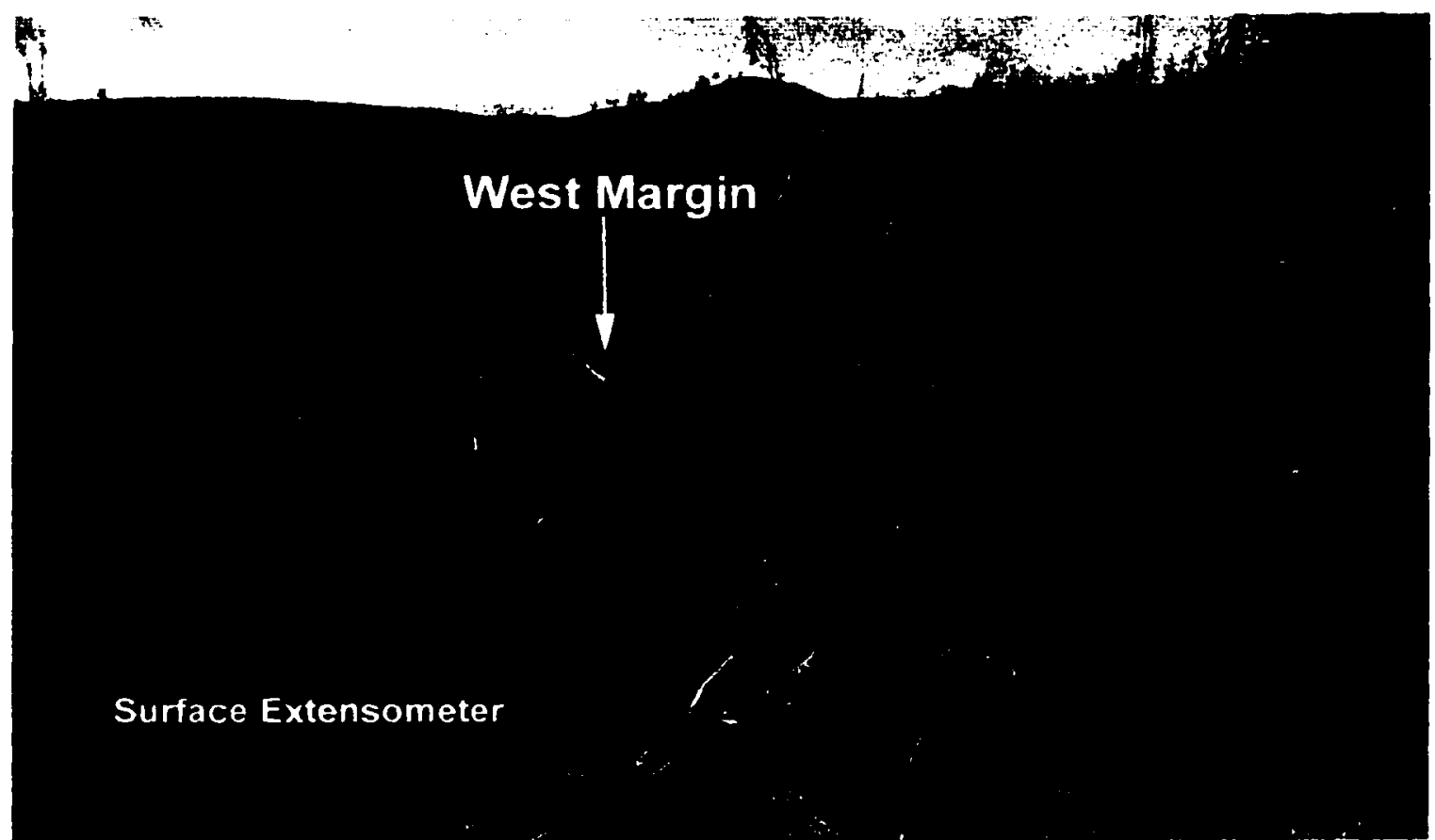

Figure 14. East-to-west view of the upper section. Photo taken 4/2/97.

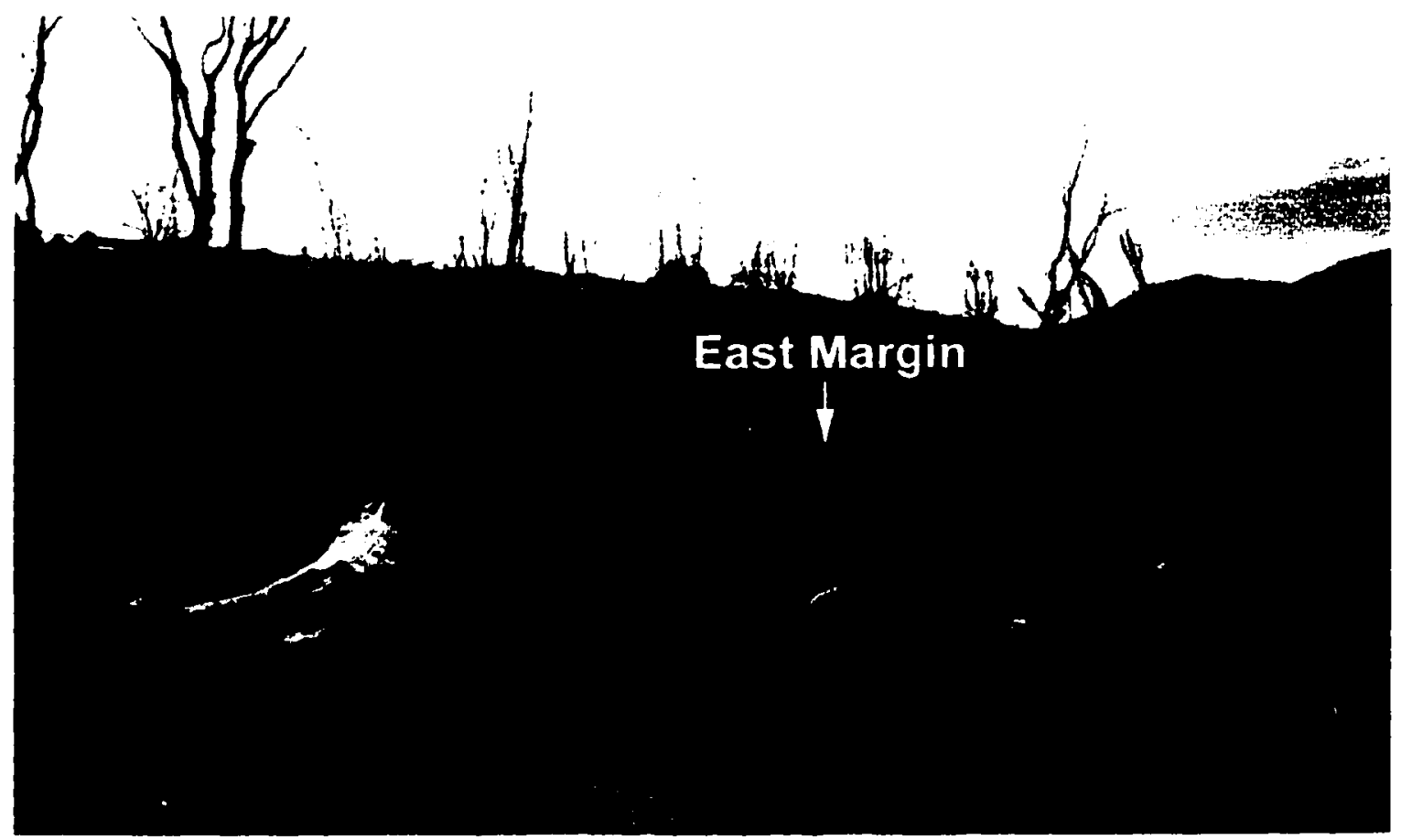

Figure 15. West-to-east view of the upper section. Photo taken 4/2/97. 


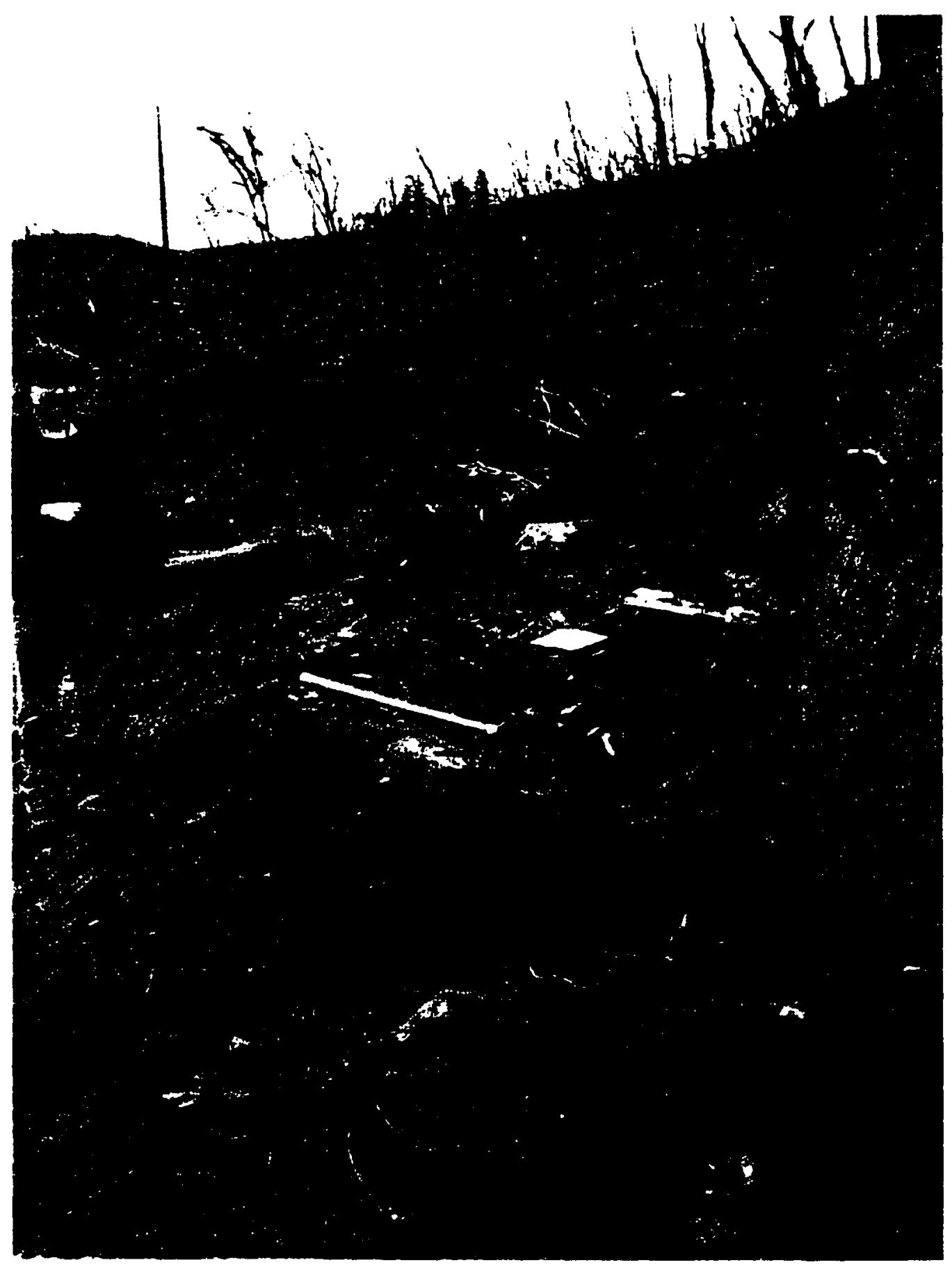

Figure 16. Photo showing a minor scarp in the upper section of Cleveland Corral. Photo taken 4/12/97. View to the west. 


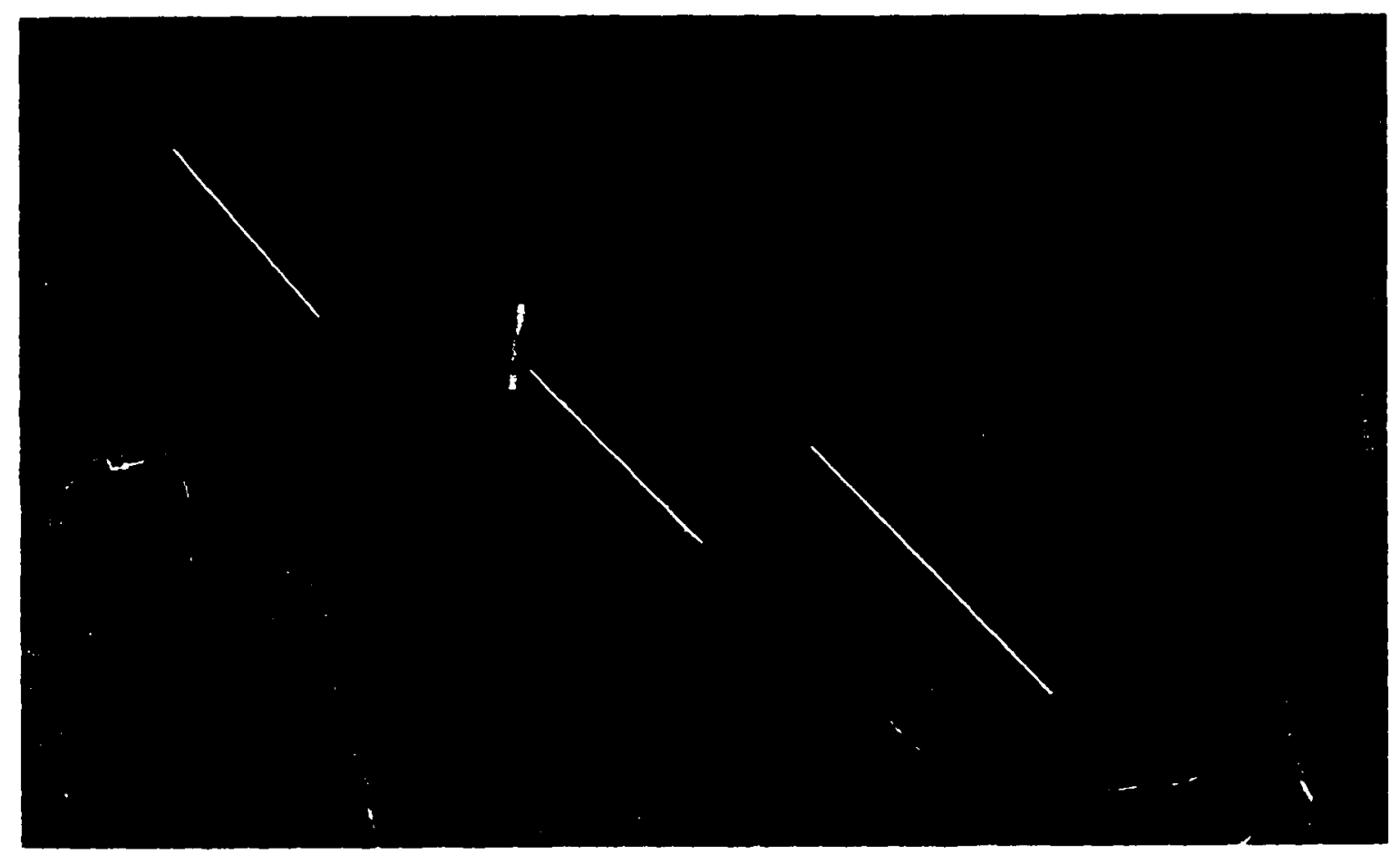

Figure 17. Dip-slip striations along the upper east margin of the lower section. Photo taken 4/2/97.

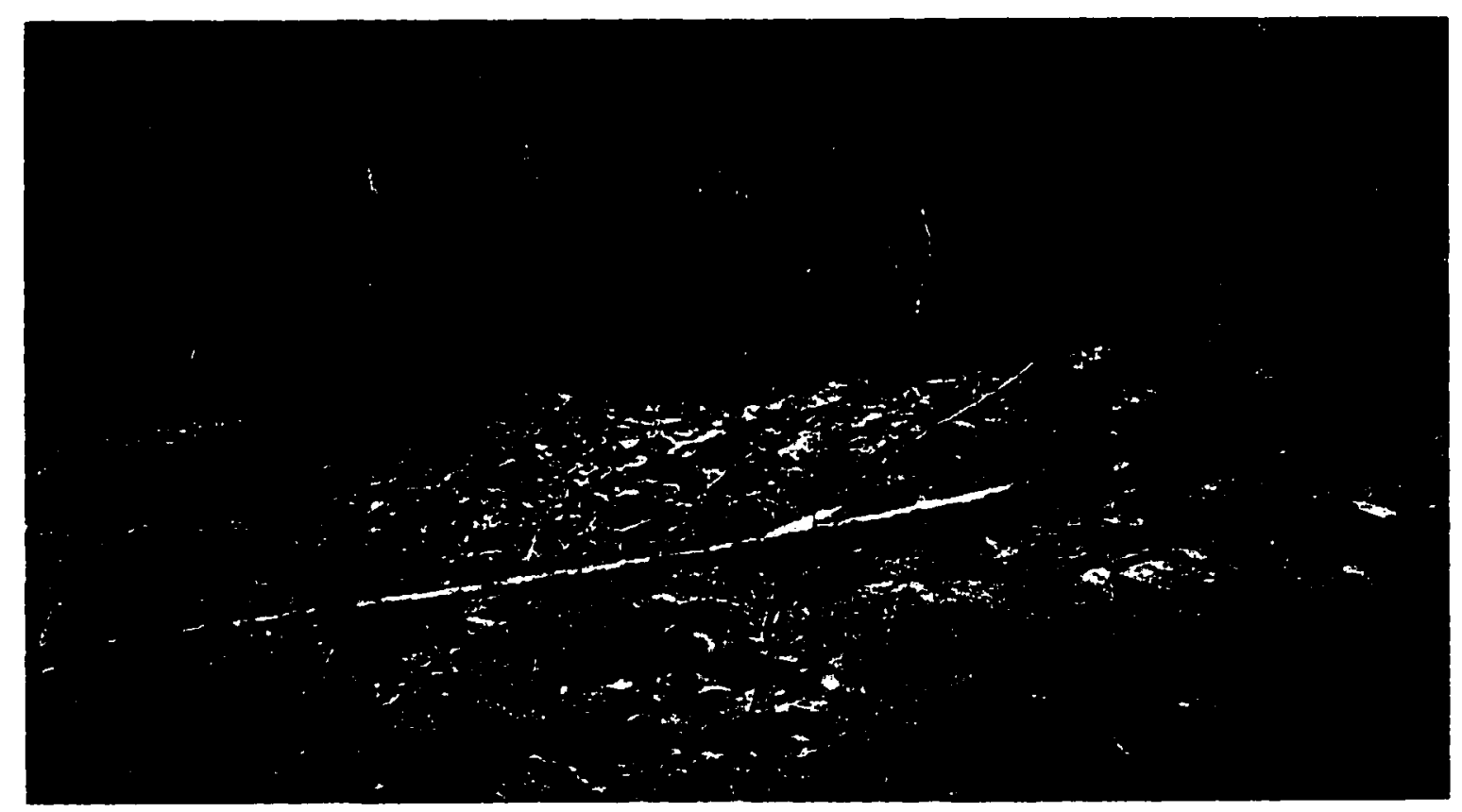

Figure 18. Talus pile 10 meters south-west of upper section toe bulge. Photo taken $5 / 2 / 97$. View to the southwest. 
The talus pile restricts, diverts, and perhaps divides the southwestern motion of the upper slide material (Figs. 10,18). Regardless of whether the talus pile is the result of mass wasting or an outcrop providing structural control, it is clearly a resisting force preventing or delaying failure of the upper section toe bulge, into the gully beyond the western margin. Failed material from the toe bulge and upslope material would likely be diverted by the talus pile, down a narrow chute leading to a broad flat area to the SSE, thereby loading the uppermost portion of the middle section (discussed below).

Groundwater was evident near the surface of the upper section of the slide until July 1997. Dark moist areas were observed on the low exposures of the head scarp and two minor scarps. The same indications remained throughout the year at the exposed dipslip face forming the eastern margin of the upper section (Fig. 17).

Geomorphic features of the Middle Section in June 1997

The northernmost portion of the middle section is a flat area of sandy colluvium in the vicinity of aerial photo target 5 (AT-5), (Plate 1). The northeast margin is defined by a bedrock knob and the western margin consist of a high steep scarp supported with material bound by the roots of scrub brush. Colluvium varies from dark red material near the northwest portion of this section, to gray/brown material found on the remaining 90 percent of the middle, and 100 percent of the lower section.

Instability along the northwestern margin of the middle section is the result of over steepening of the slopes by previous slope failures and continual removal of downslope material by the stream at the base of the western gully, thus minimizing the resisting force to downslope movement. Along the northwestern margin of the middle section are two 
translational slides defined by a series of scarplettes located just SSW and NNW of AT-7 (Plate 1). The NNW slide occurs on the gentle ridge forming the west margin of the slide leading down into the steep western gully. It appears as a graben with numerous small, stepped scarps at the head versus one larger head scarp. Numerous tension cracks are oriented orthogonal to the direction of movement. If this ancillary failure area proceeds at a rate that exceeds the main slide body as a whole, its head scarp will advance upslope to the point where material from the northern portion of the middle section would be conveyed into the western gully (Fig. 19). This will remove driving force material from the main channel, or even behead the main body of the slide. The slide to the SSW of AT7 has a distinct toe bulge defined by thrust planes oriented NNW to SSE located outside of the distinct boundaries of the Cleveland Corral slide. The overall slope movement for both secondary translational slides is SSW toward the gully beyond the west margin.

Other failures in this area resulted from the toppling of 2-3-m-high cliffs in colluvium. Intertwined roots provide a resisting force for the uppermost $1 \mathrm{~m}$ of colluvium (Fig. 20). There are numerous minor scarps and tension cracks upslope. Near the crest of the western margin, numerous distinct blocks of colluvium, approximately $2.5 \mathrm{~m}$ long and $1.5 \mathrm{~m}$ wide, tilt in the direction of slope movement. As undercutting from downslope failure and surface wash proceeds, the scarp eventually over-steepens to the point where the root strength can no longer provide stability, and blocks as wide as 4-5 m, either topple or slide down slope. This process may continue upslope to the point where material from northern middle section and southern upper sections may be captured and diverted into the western gully. Figure 21 is a line drawing depicting major geomorphic features. Photo numbers correspond to figure numbers in the text. 


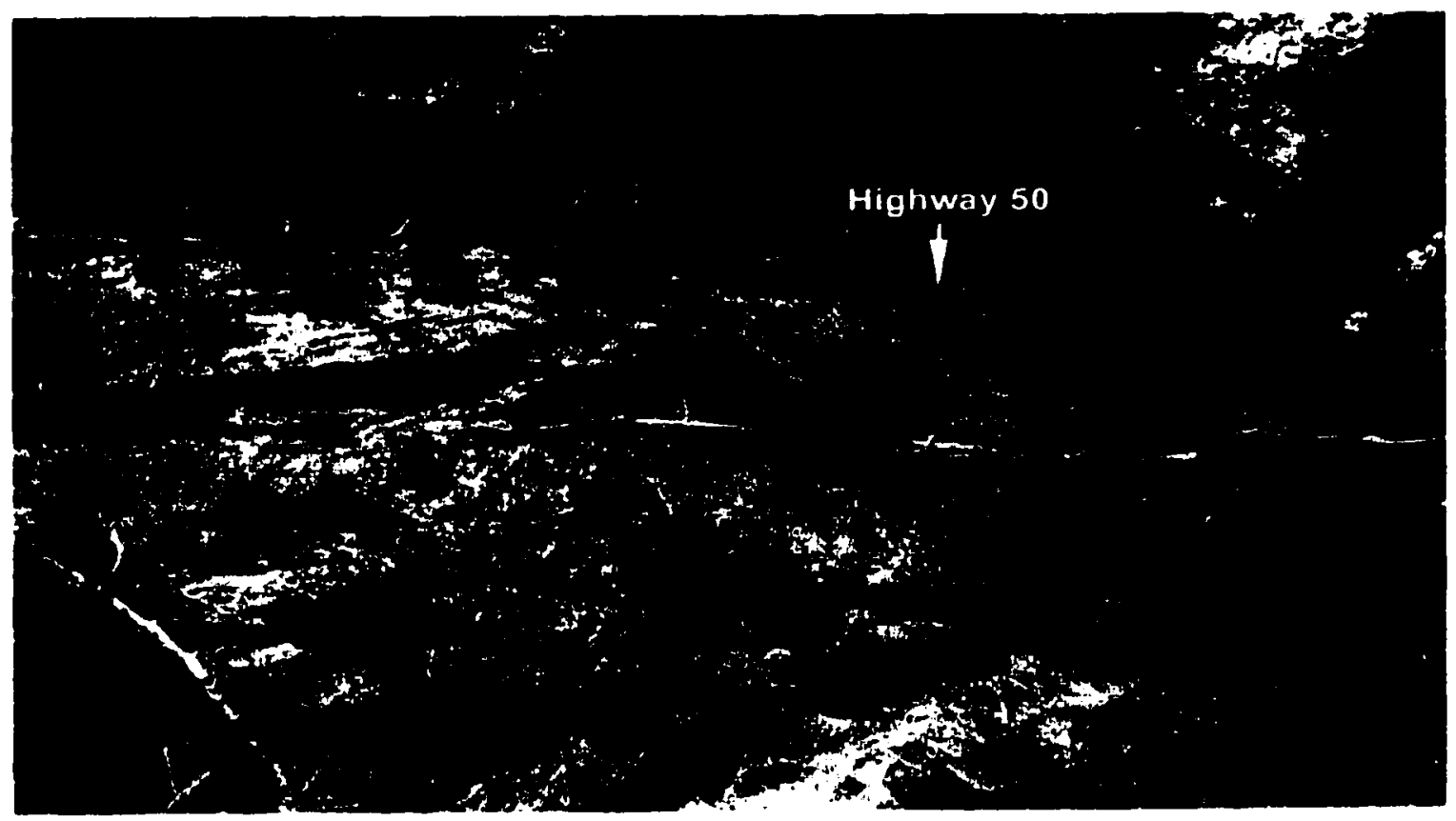

Figure 19. Graben located on the west upper margin of the middle section. The material is failing towards the western gully. Photo taken 2/9/98. View to the southwest.

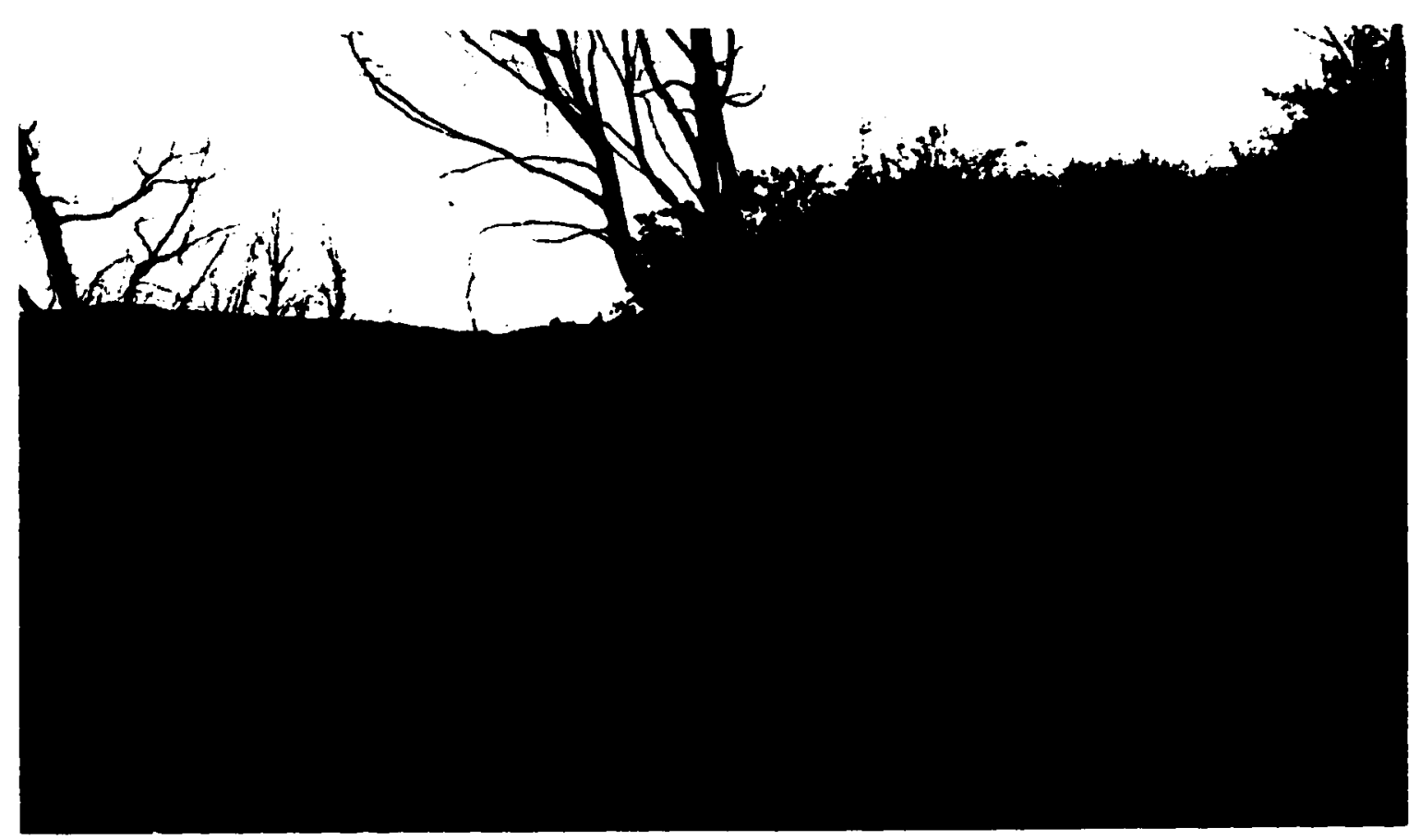

Figure 20. Mass wasting along the west upper margin of the middle section. Photo taken $3 / 6 / 97$. View to the northwest. 


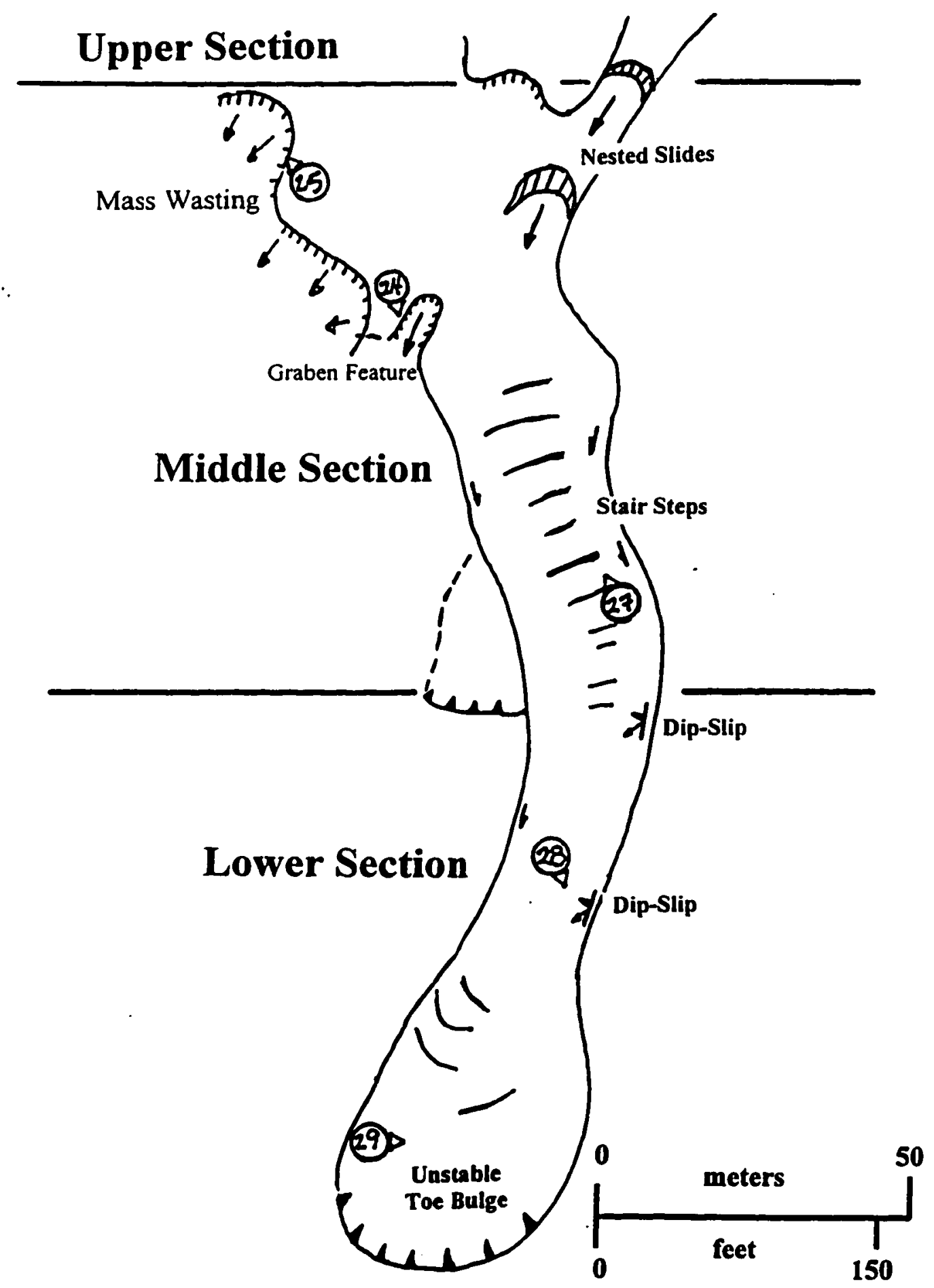

Figure 21. Major geomorphic features of the middle and lower sections of the Cleveland Corral landslide. The numbers correspond to figure numbers for photos in the text, showing the location where, and direction in which each photo was taken. 
The southern middle section defines the northern lower section. It consists of numerous blocks tilted downslope (10-20 degrees) typically no wider than $1.5 \mathrm{~m}$, with a long axis oriented predominantly orthogonal to the direction of failure (S). At this point on the slope, the blocks give the appearance of a staircase (Fig. 22). 


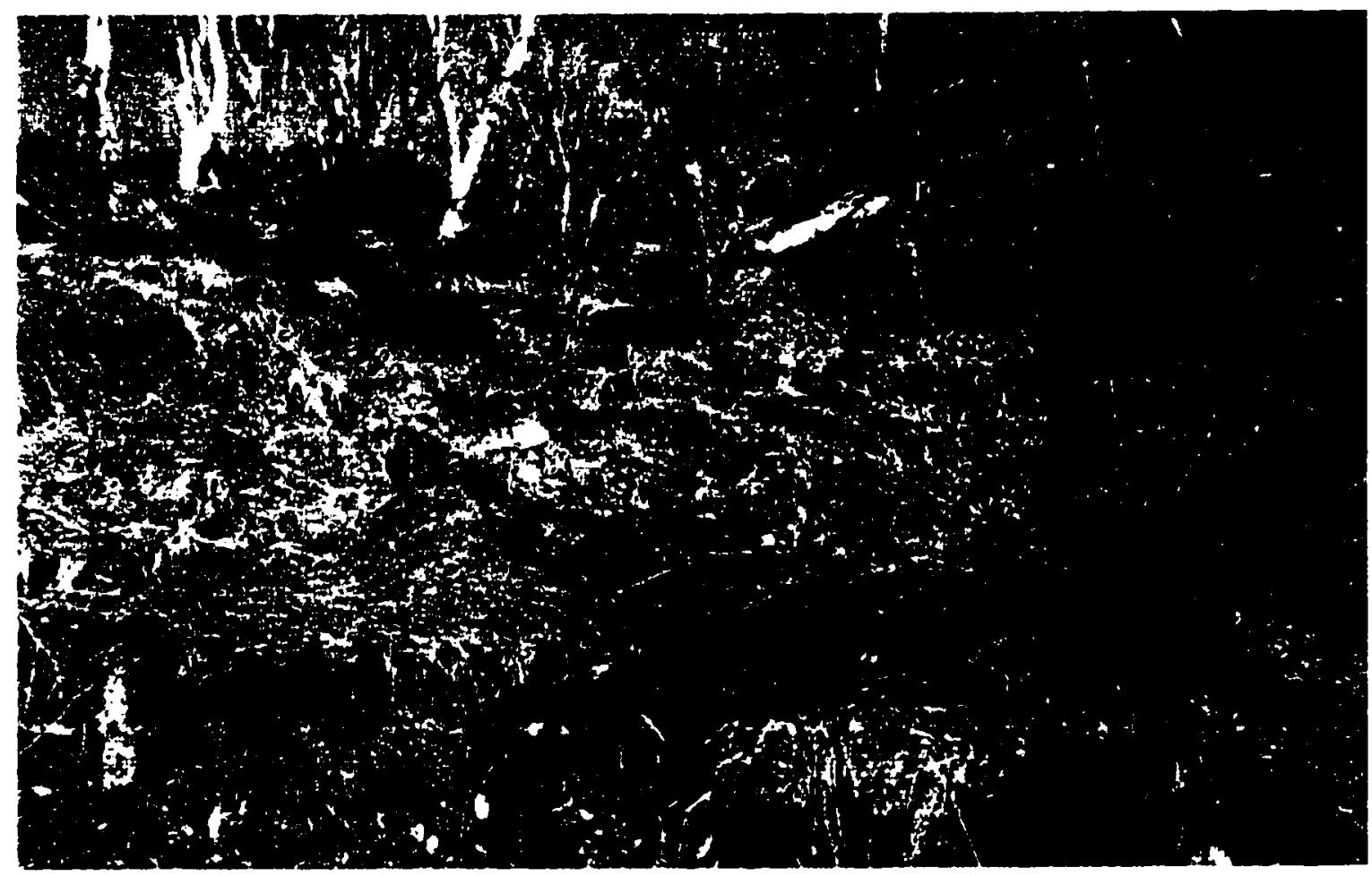

Figure 22. Stair-step topography throughout the middle section. Photo taken $2 / 9 / 98$. View to the north. 
Geomorphic Features of the Lower Section in June 1997

The lower section of the slide exhibits the effects of a well-developed, creeping translational slide. The main body of the lower section is a narrow trench, (Fig. 10) the bottom of which is approximately $5 \mathrm{~m}$ below the natural topographic surface. Failure initiated along the large dip-slip face that forms the eastern margin of the lower section (Fig. 23). The dip and plunge of striations show that the material failed directly down-dip towards the SW. However, the dominant structural control produced by the geologic contact caused the overall slide track direction to be south toward Highway 50 .

A large toe bulge with thrusts and toppled trees along its boundary defines the bottom of the slide (Fig. 24). The surface of the toe is very disturbed, with numerous tension cracks oriented roughly parallel and orthogonal to the leading edge of the toe. Several minor, arcuate scarps are present. Several large tree stumps have, together with their root systems, been pushed over in the downslope direction. This is a result of downslope creep and a compressive, topographic uplift due to the accumulation of material meeting resistance at the terminus. Resisting force is provided by the numerous large, live, vertical pine trees at the toe boundary and the diorite bedrock buttress just above Highway 50 .

The western margin of the lower section's main track has a 1-m-high ridge of light gray to tannish yellow colluvium deposited laterally along its entire length. This occurred when failed upslope material encountered resistance from the developing toe bulge. The slower or stationary downslope material caused the upslope material to accumulate and overflow in the constriction forming the main track of the lower section (Fig. 2). 


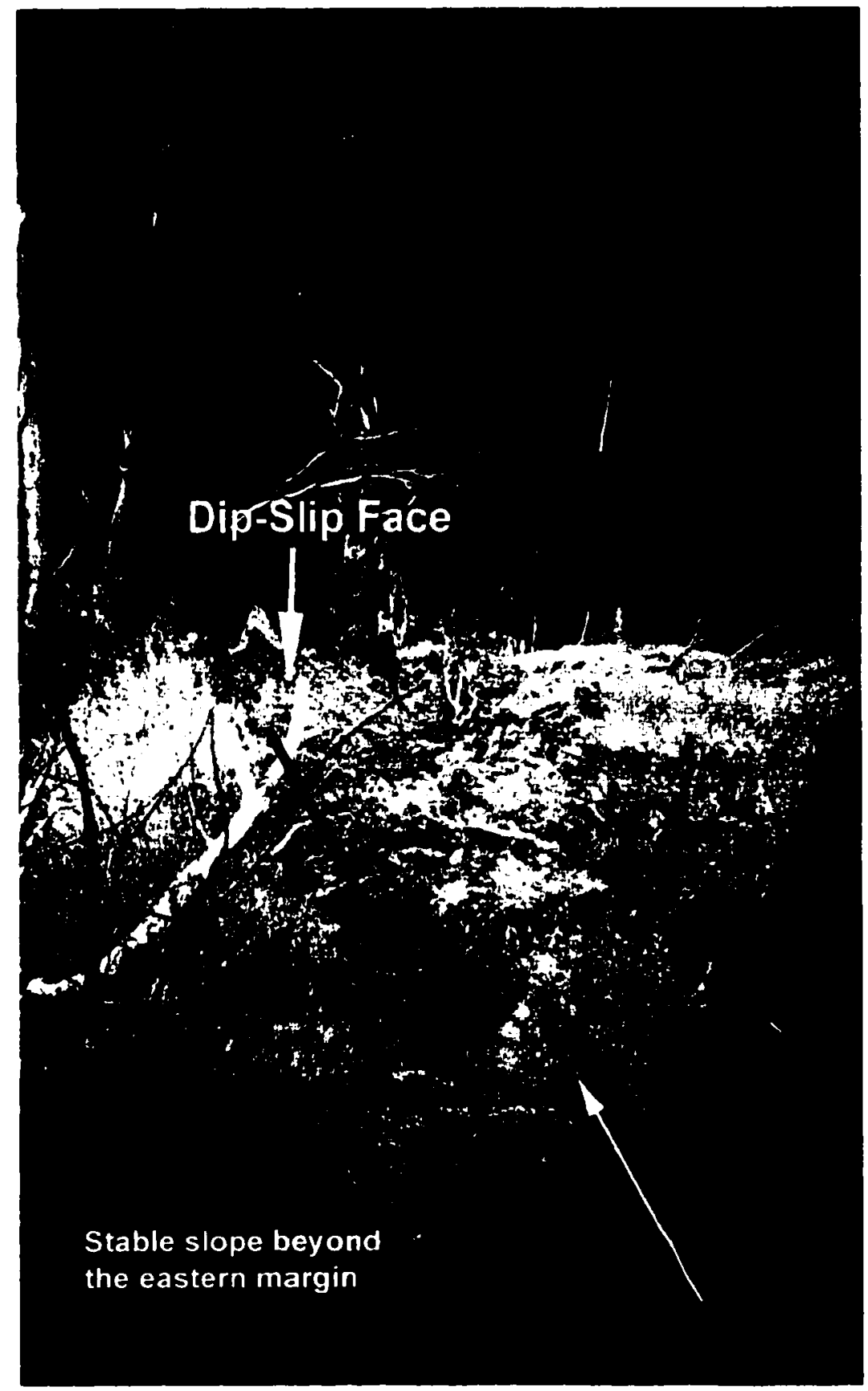

Figure 23. Photo showing the east margin of the lower section of the Cleveland Corral landslide. Photo taken $3 / 6 / 97$. View to the south. 


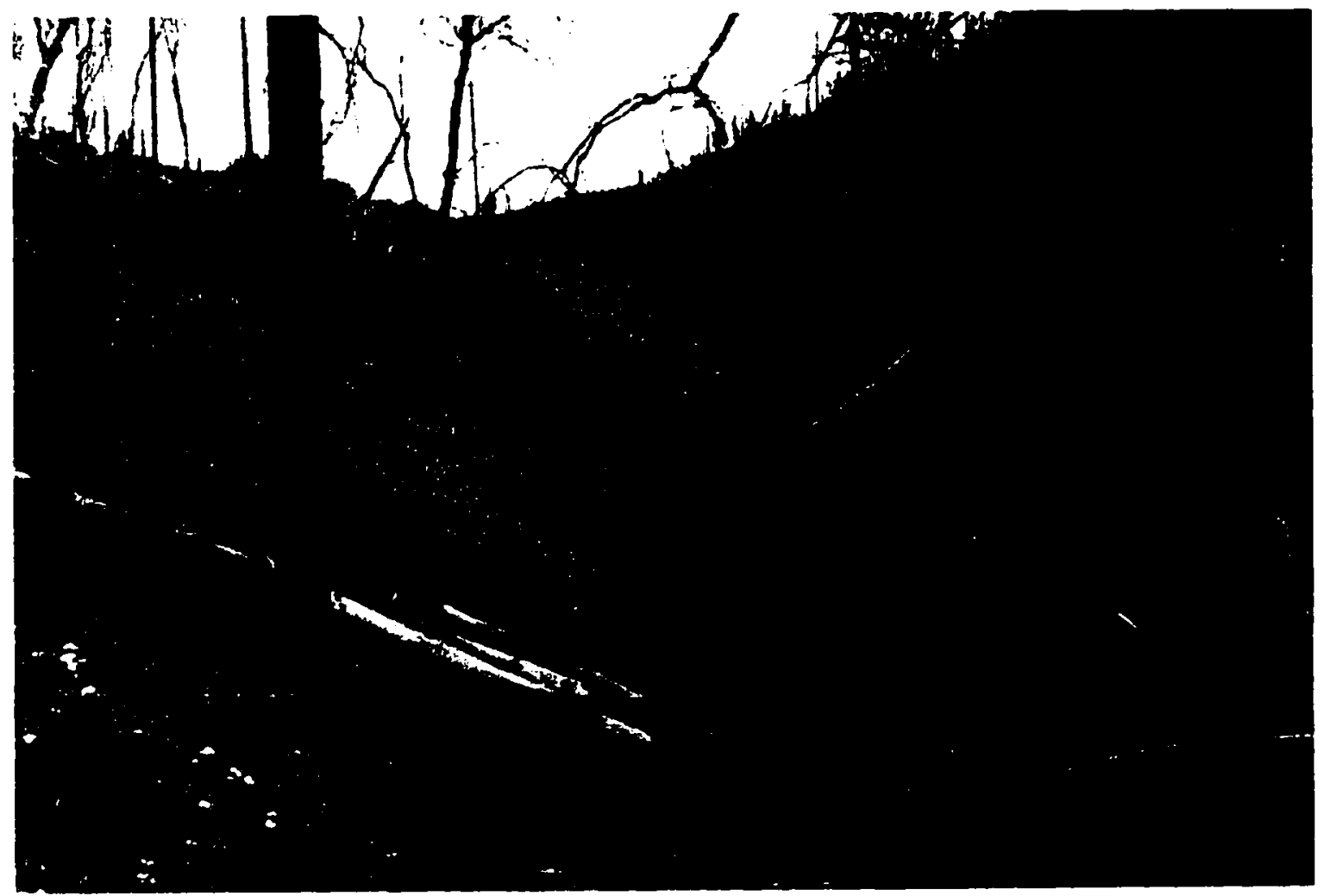

Figure 24. Trees toppled by the downslope movement of the lower section toe bulge. Photo taken $3 / 6 / 97$. View to the east. 


\section{Subsurface Investigation}

The USGS conducted a seismic refraction survey at Cleveland Corral in July 1997, in an attempt to characterize the failure plane(s) and to determine the depth to bedrock. Preliminary results from $P$ and $S$ wave velocities (R. Williams, USGS, unpub. data, 1998) indicate that the depth to bedrock is approximately $9-11 \mathrm{~m}$ (Fig. 10). The preliminary seismic velocities provided no clear indication of the failure surface, most likely because there is no significant velocity contrast across the failure surface. Therefore the author considers the failure surface to reside at the bedrock/colluvium contact. $\mathrm{S}$ and $\mathrm{P}$ velocities below 9-11 $\mathrm{m}$ at the upper section were consistent with weak granitic material believed to be bedrock. P velocities below 9-14 $\mathrm{m}$ at the lower section also were consistent with weak granitic material believed to be bedrock.

In October 1997, borings were conducted in the upper section to install piezometers and down-hole extensometers for the USFS, USGS, and Caltrans (Fig. 10).

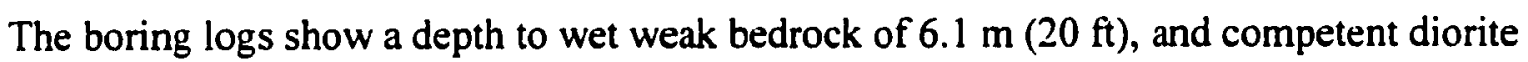
at $6.7 \mathrm{~m} \mathrm{(22} \mathrm{ft)} \mathrm{(A} \mathrm{Boyd,} \mathrm{El} \mathrm{Dorado} \mathrm{National} \mathrm{Forest,} \mathrm{unpub.} \mathrm{data,} \mathrm{1997).} \mathrm{Samples} \mathrm{were}$ collected with a $45.7 \mathrm{~cm}$ ( $18 \mathrm{in}$ ), split spoon sampler at $1.5 \mathrm{~m}$ intervals and at any point where a significant change in drilling resistance was detected. Indications of a definitive failure plane within the colluvium were not found during the drilling process.

The complexity of this site was evident by comparing the two preliminary seismic profiles with the logs for borings 5 and 6 (Fig. 10). The seismic profiles favor a two-layer profile, however a three-layer profile is possible. The logs from borings 5 and 6 have different depths to bedrock and different types of colluvial material even though the 
distance between these borings is approximately $1 \mathrm{~m}$. The distance from the site of borings 5 and 6 to the seismic line is approximately $7 \mathrm{~m}$ (Figs. 25-29).

Data taken from the surface and subsurface investigation were used to establish a simple longitudinal cross section (Fig. 30). The cross section was use as the basis for the computer and mathematical slope stability models. 
Cleveland Corral Upper Section

2 - Layer Case

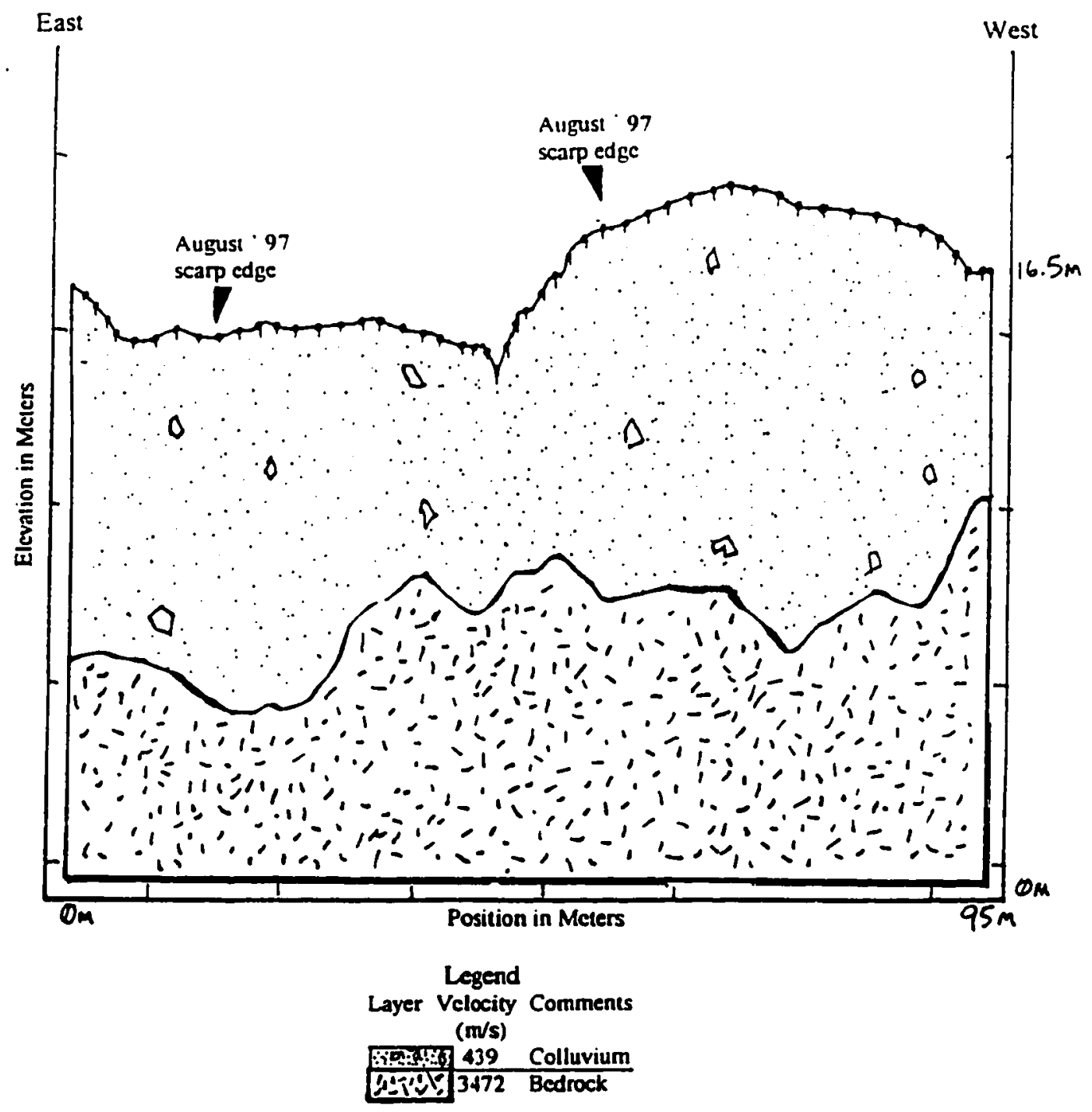

Figure 25. Provisional USGS seismic results showing depth of colluvium and the nature of the bedrock/colluvium contact in the upper section of Cleveland Corral landslide (modified from R. Williams, USGS, unpub. data, 1998). The upper section seismic line can be found in the upper section of Figure 10. 
Cleveland Corral Upper Section

3- Layer Case

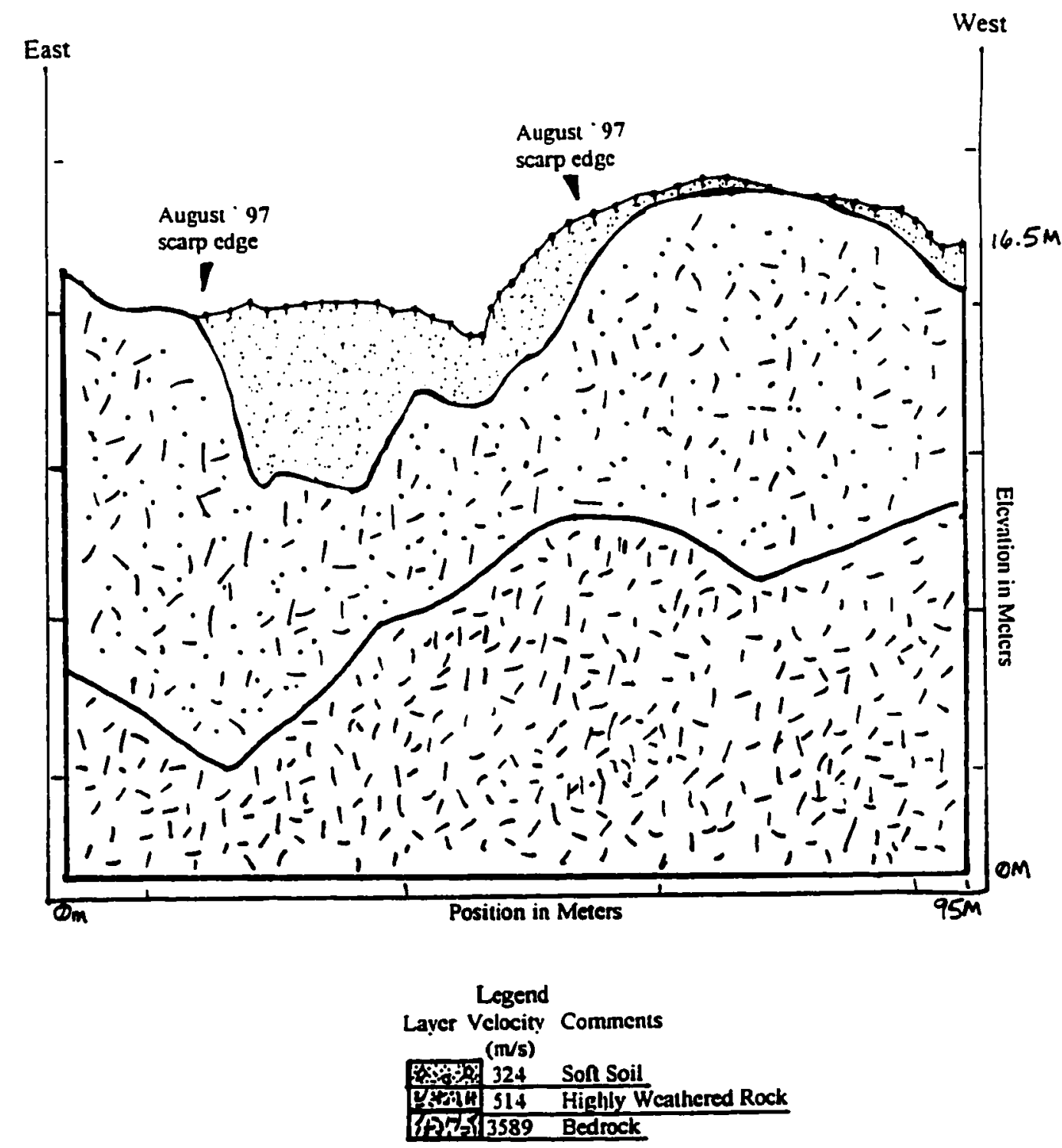

Figure 26. Provisional USGS seismic results showing a complex 3-layer case indicating the existence of previous landslide material in the upper section of Cleveland Corral landslide (modified from R. Williams, USGS, unpub. data, 1998). The upper section seismic line can be found in the upper section of Figure 10. 


\section{Cleveland Corral Seismic Survey \\ Preliminary Results}

\section{Cleveland Corral Middle Section}

P.Wave Seismic Protile

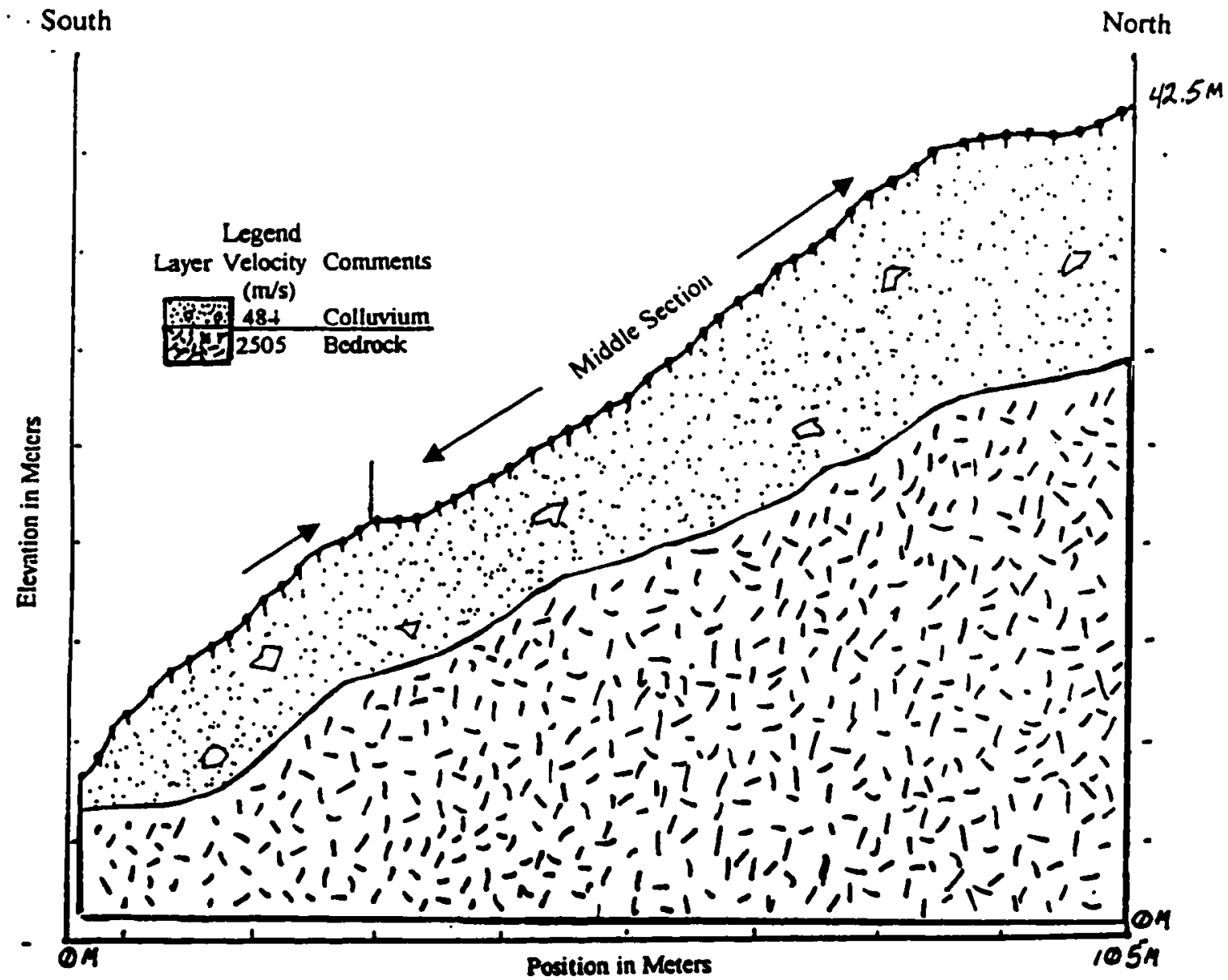

Figure 27. Provisional USGS seismic results showing depth of colluvium and the nature of the bedrock/colluvium contact in the middle and lower sections of Cleveland Corral landslide (modified from R. Williams, USGS, unpub. data, 1998). The middle and lower section seismic line can be found in the middle and lower sections of Figure 10. 


\section{LOG FROM BORING 5}

Log recorded from boring drilled October 15. 1997.

Measurements for drilling and logging were conducted in English units.

Equipment: Hollow stem auger. 6 inch diameter. pneumatic rock hammer. and 18 inch split spoon sampler.

Elevation: $3920 \mathrm{ft}(1195 \mathrm{~m})$.

Total Depth: 35.25 feet.

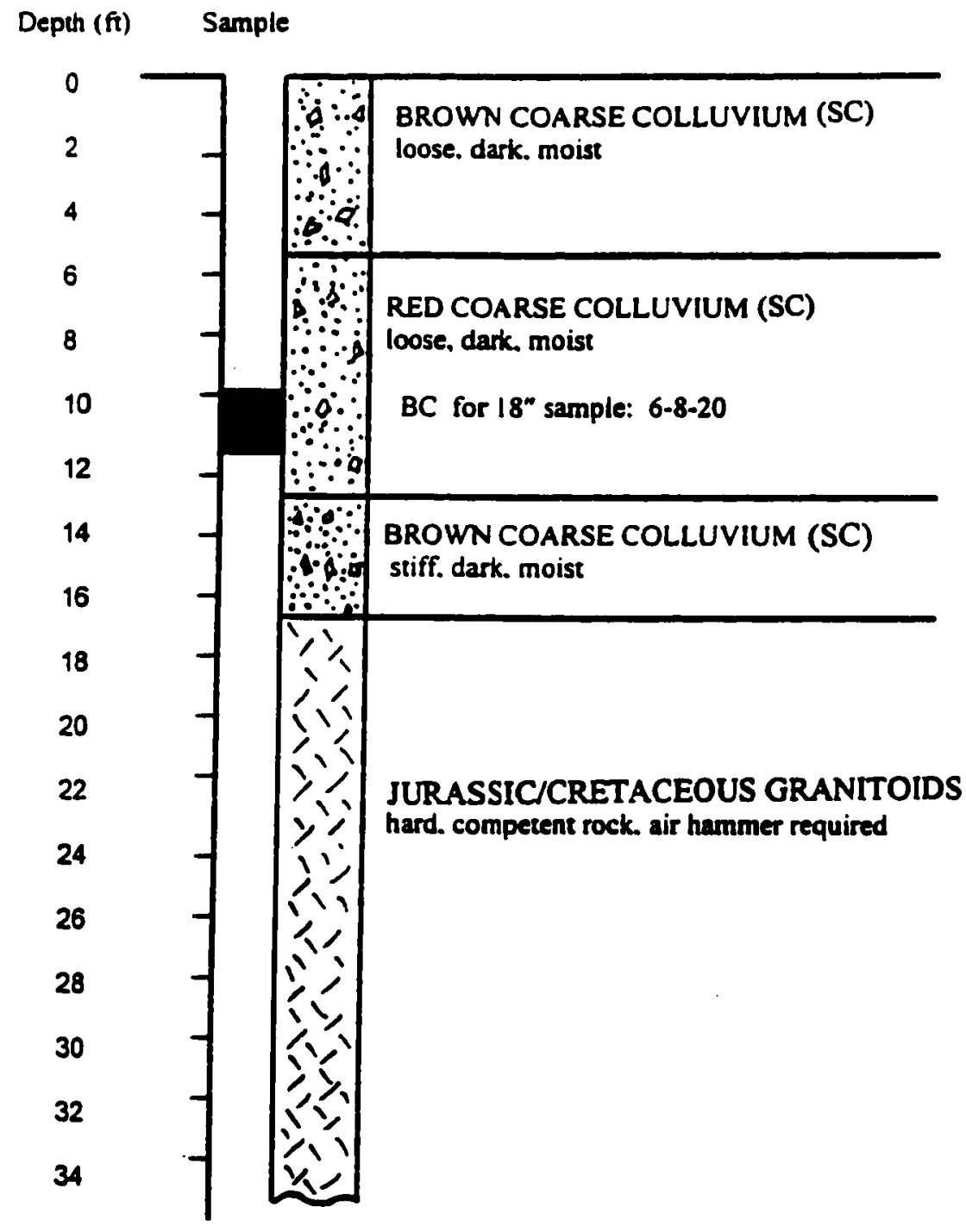

Figure 28. Geologic profile developed from borings in the upper section of the Cleveland Corral landslide (modified from A. Boyd, El Dorado National Forest, unpub. data, 1997). The boring locations can be found in the upper section of Figure 10. 


\section{LOG FROM BORING 6}

Log recorded from boring drilled October 15, 1997.

Measurements for drilling and logging were conducted in English units.

Equipment: Hollow stem auger, 6 inch diameter, pneumatic rock hammer. and 18 inch split spoon sampler.

- Elevation: $3920 \mathrm{ft}(1195 \mathrm{~m})$.

Total Depth: 26 feet.

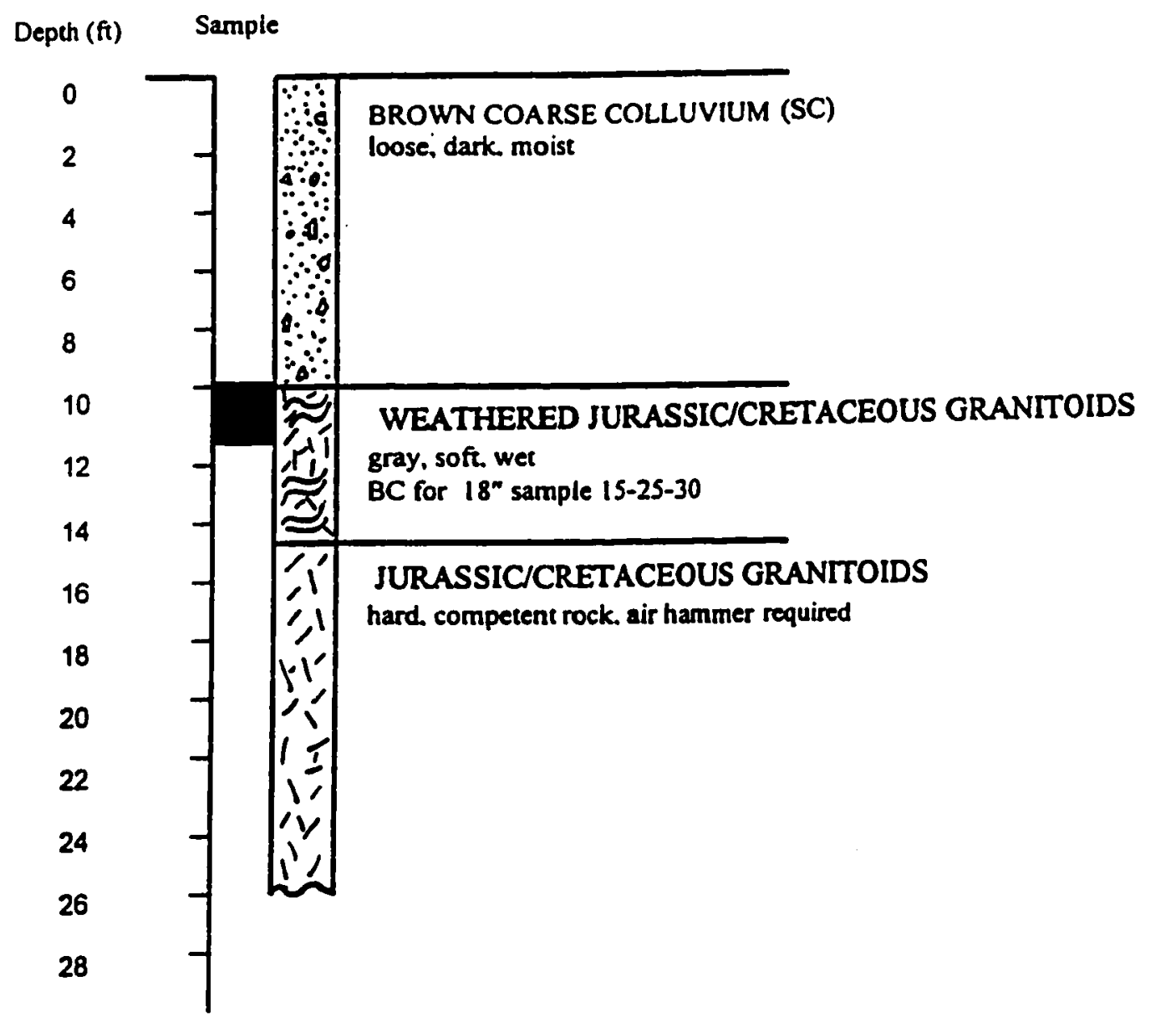

Figure 29. Geologic profile developed from borings in the upper section of the Cleveland Corral landslide (modified from A. Boyd, El Dorado National Forest, unpub. data, 1997). The boring locations can be found in the upper section of Figure 10. 


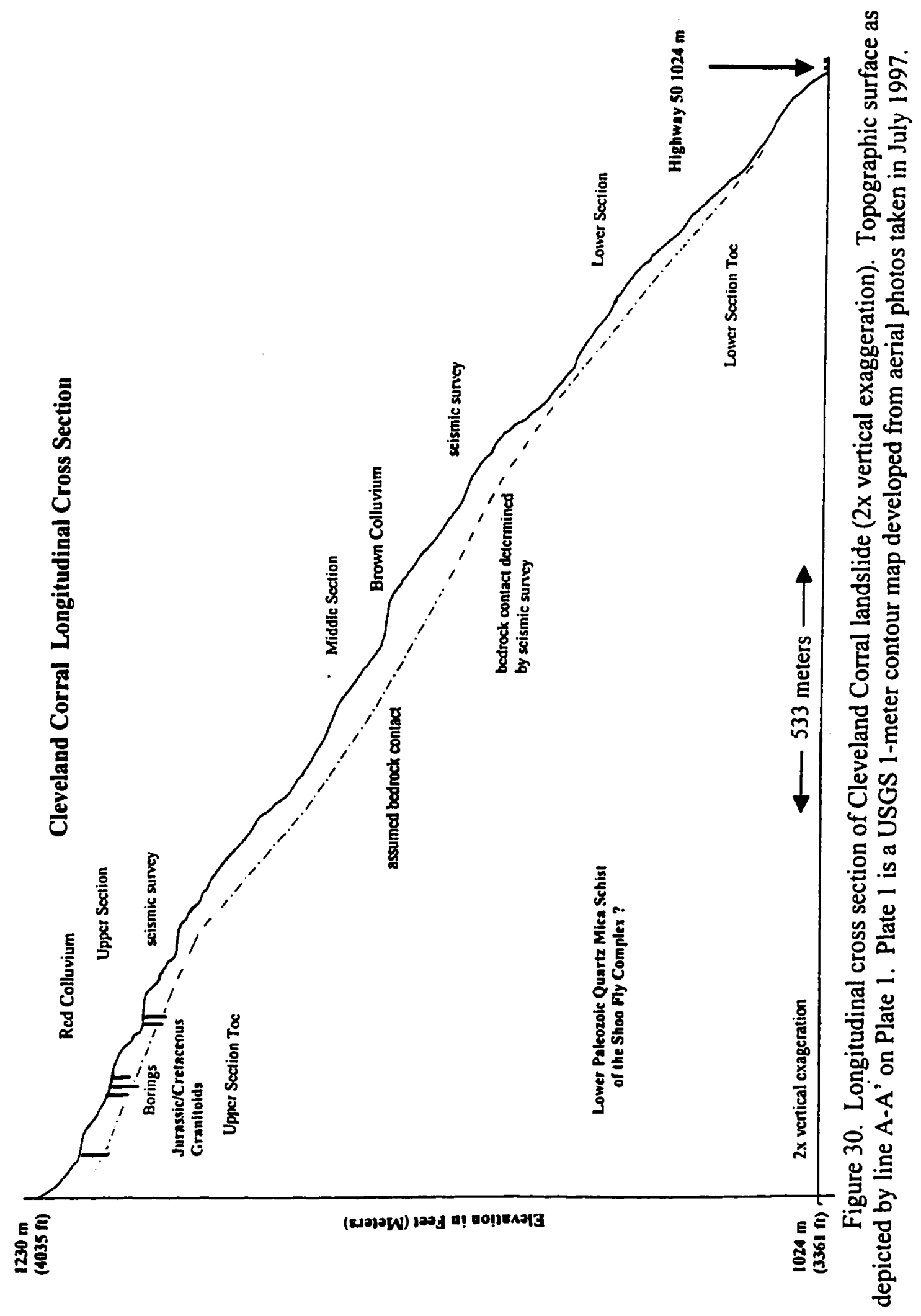




\section{SLOPE STABILITY}

\section{Geologic Factors}

The weathered granodiorite bedrock underlying the area provides a surface of low shear strength and a permeability contrast with the colluvium. This contact between the bedrock and heterogeneous colluvium becomes the site of high pore water pressures, and therefore, a likely failure plane.

The wsw dip of the strata at Cleveland Corral is attributed to the western limb of a nearby antiform (Jones and others, 1997). The dip of the foliation is parallel or sub-parallel to the natural topography (Fig. 6). This condition lends itself to slope failure.

The presence of the Mehrten Formation debris within the Cleveland Corral area indicates that previous landslide activity has conveyed the material from the ridge tops to the lower slopes adding to the lithologic heterogeneity of Cleveland Corral. Above Ice House Road, the more resistant Mehrten forms a protective cap above the granodiorite. This has allowed the granodiorite on the steep south-facing slopes to weather in-situ to a greater depth than if it were constantly eroded, thereby producing deep layers and pockets of colluvium. The loss of shear strength in the upslope colluvium due to in-situ weathering reduces the colluvium's ability to maintain stability on a slope. This deep colluvium above Ice House Road could fail catastrophically of its own accord and load the current upper section. Alternatively, the current head scarp could continue to migrate further upslope, removing the support for the deep colluvium above Ice House Road. 


\section{Fire Effects}

The Cleveland Corral forest fire of 1992 destroyed nearly all organic ground cover and vegetation on Cleveland Corral (A Boyd, El Dorado National Forest, unpub. data, 1997). As a result, the local water budget has been influenced by the loss of interception and evapotranspiration, both of which lower the water table. A more recent stability factor is the decay of the larger trees' root systems. After 5 years of decay, many trees have broken off just below the ground surface because of wind and/or slope failure, exposing their decayed root system. The resulting depression provides an additional ponding and infiltration point for surface runoff. Root systems contribute to soil strength by providing an additional cohesion component. Sidle and others (1985) state that root systems increase soil strength by binding unstable soil mantles to stable sub-soils or substrata. This effect is most pronounced when a potential failure zone exists within the rooting zone. Root systems form a dense interwoven network in the upper 30 to $50 \mathrm{~cm}$ of soil, and this network provides lateral membrane strength that tends to reinforce the shallow soil mass and hold it in place (Fig. 31). Roots of individual trees may provide deeper anchors thus creating stabilizing soil arches that extend across the slope. However, at Cleveland Corral the depth of the colluvium prevents tree root systems from anchoring into the bedrock below. Stumps in the upper section have shown measured downslope movement of several meters (J. Roering, personal commun., 1997). 


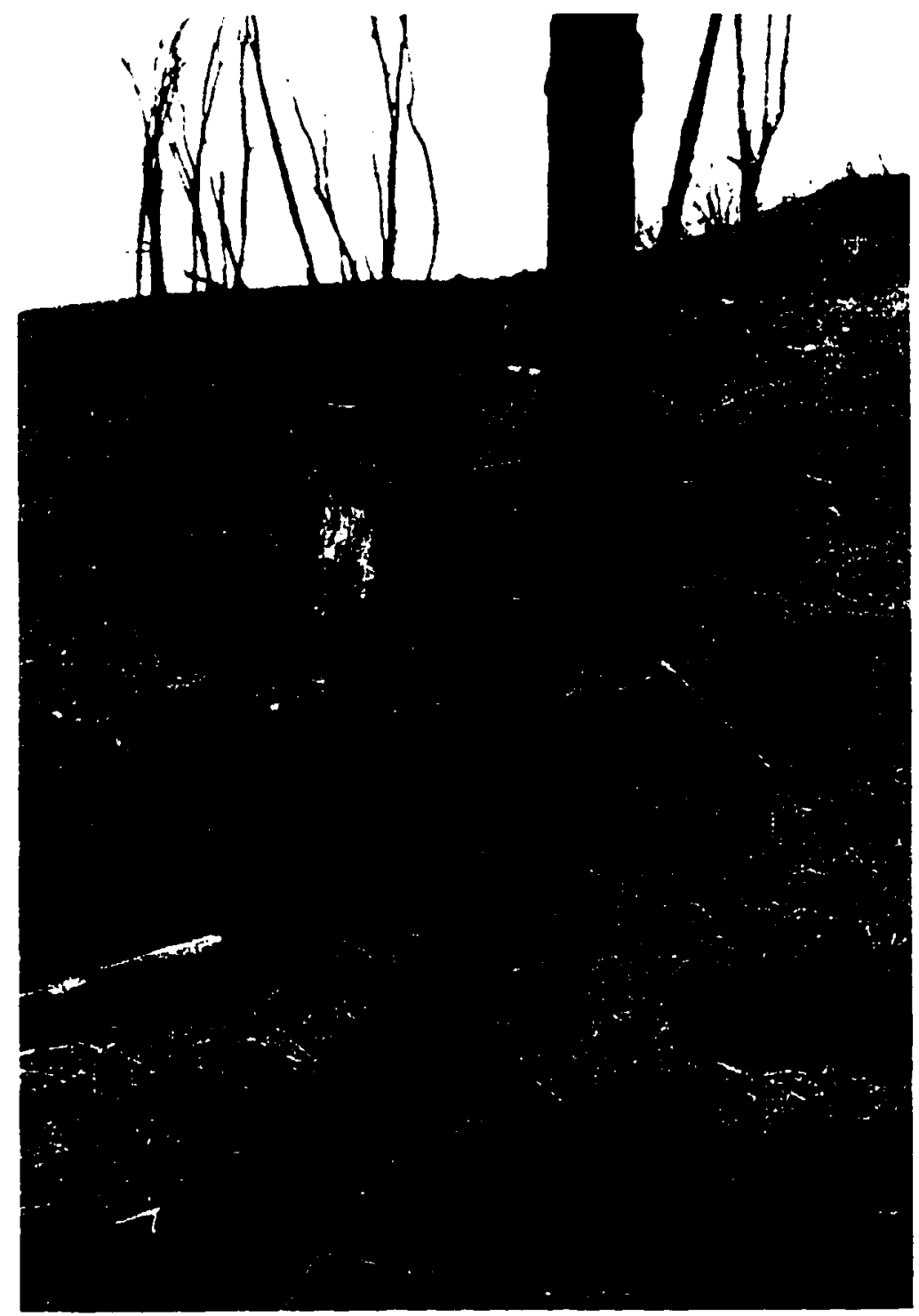

Figure 31. Stump block and root cylinder in the upper section of Cleveland Corral landslide. Photo taken 4/8/97. View to the northwest. 


\section{$\underline{\text { Storms }}$}

Infrequent storms with high rainfall totals, occurring during periods of above average rainfall, are the most significant triggers of slope failures along the Highway 50 corridor. Although lack of vegetation plays a significant role and the highest percentage of landslides occur within the area burned in 1992, the USFS identified numerous landslides in nearby heavily forested areas as well (A Boyd, El Dorado National Forest, unpub. data, 1997). Much research has been conducted to determine what combination of rainfall duration and intensity (rainfall threshold) will trigger a landslide. Kesseli (1943) determined that mobilization occurred when the rainfall intensity caused infiltration to exceed drainage, thereby creating a perched water table, which increases the pore water pressure at the failure surface. The pore pressure created by the perched water table has been determined to be the most likely cause for the initiation of slope failure in colluvial material (Campbell, 1975).

\section{Engineering Factors}

Whereas a rotational slide tends to restore the displaced mass to equilibrium, translation may continue unchecked if the failure plane is sufficiently inclined and of sufficient length. As translational sliding continues, the displaced mass may break up, particularly if its velocity and/or water content increases. The disrupted mass may then flow, becoming a debris flow rather than a slide. Translational sliding often follows discontinuities such as faults, joints, and bedding surfaces or the contact between rock and residual or transported soils (Cruden and Varnes, 1996). Field observations at Cleveland Corral, including downslope tilting of trees and the shallowness of the colluvial material indicate that translational mechanics are in effect. Howard and others (1988) identified five stages of a translational slide event, known as a soil slide, which is similar to a debris slide-debris flow (Fig. 32). The following is Howard's analysis of each phase: the first 


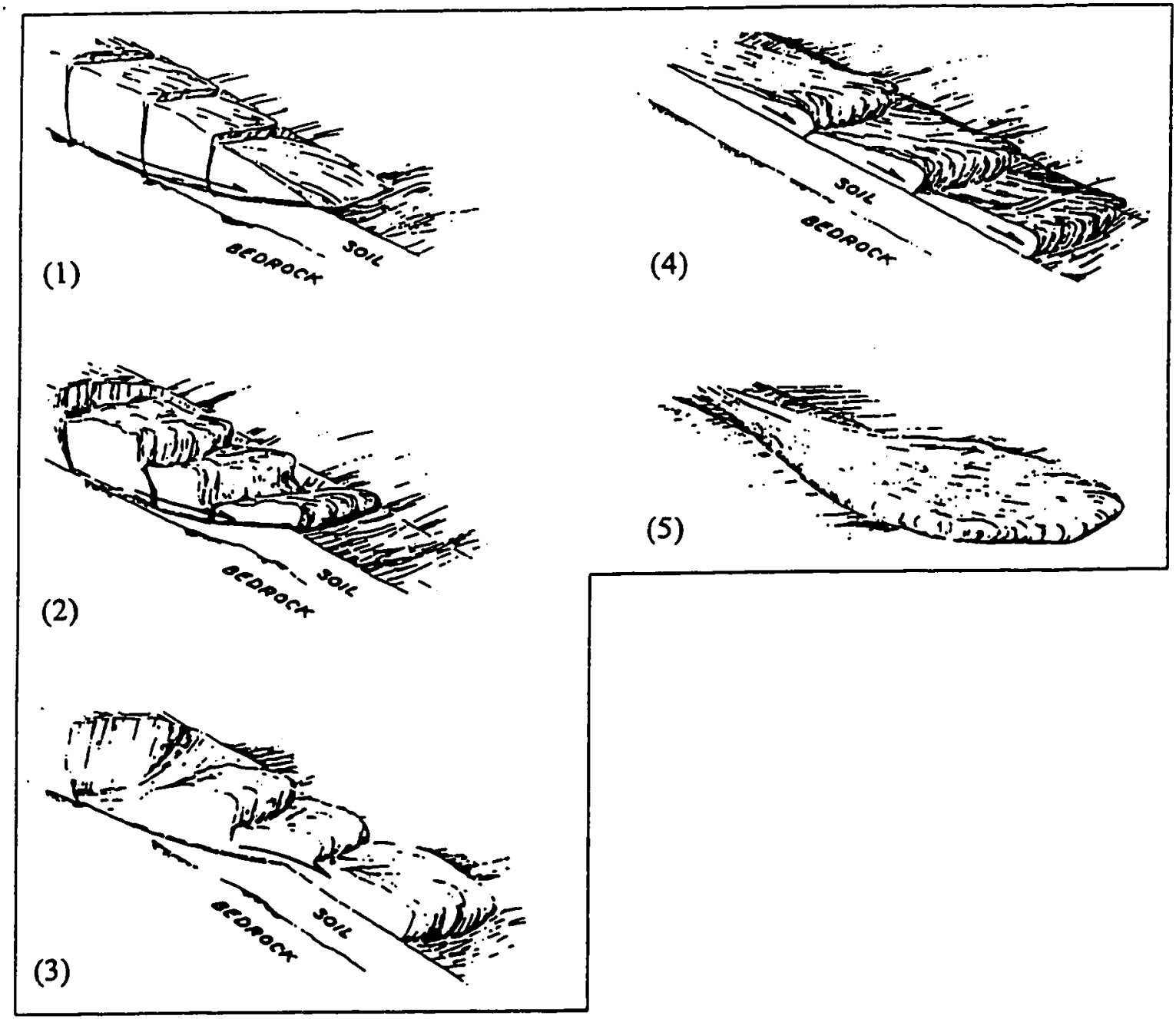

Figure 32. 5 phases of a transiational slide (modified from Howard and others, 1988). 
phase occurs as the soil slides along at, or just above, the soil-bedrock contact. The sliding process is controlled by tension cracks in the soil and by high pore water pressures caused by a permeability contrast between soil and bedrock. With continued movement, the second phase evolves as internal shearing causes a reduction in strength of the soil resulting in increasing levels of plastic deformation, and dilation of the soil mass. Water from tension cracks is drawn into the dilating mass, further weakening and disaggregating the soil material. In the third stage, the soil material begins to flow over the ground surface. As the initial mass continues to flow down the slope, it commonly accelerates and incorporates soils and debris, forming in stage four, a debris flow. At the base of the slope, the decreased gradient causes deposition of the debris in stage five. At Cleveland Corral, the upper and lower sections exhibit phases 1-5, whereas the middle section currently exhibit phases $I$ and 2 .

The complexities and inter-relationships of topography, geology, and climate have made defining the mechanical parameters of the Cleveland Corral landslide extremely difficult. However, observations and monitoring have provided a detailed record of the precipitation and the slide's reaction to above average precipitation. Monitoring records revealed significant differences in the movements of each of the three sections of the slide. These result from the differences in mechanics, hydrology, structure, topography, and phases of slope failure.

Slope movement at Cleveland Corral since March 1997 has been slow. April 1998 experienced the highest average failure rate, only $1.2 \mathrm{~cm} /$ day. Colluvium at the shear plane has a tendency to dilate as sliding begins. This dilation increases the volume of the voids. Two events may occur at this point: 1) increased volume causes a decrease in pore pressure and the colluvial grains across the failure plane collapse and lock in place, or 2) 
the increased pore volume is recharged with pressurized pore water which forces colluvial grains apart, and allows continued movement and shearing. According to Ellen and Fleming (1987) more water must be drawn into the shear zone for failure to continue. Replacement water can come from the nearby, saturated colluvium and water-filled tension cracks. The rate of mobilization at this point depends on the degree of hydraulic conductivity of the colluvium. Higher density leads to lower permeability, which causes slow replacement of pore water and a slow rate of mobilization as seen at Cleveland Corral.

Selective mobilization is another feature of the slow, dilative colluvium found at Cleveland Corral. Emerging groundwater seepage created springs indicating saturated conditions along the eastern margin for the entire length of the slide. This abundance of water may have allowed the upper portions of the section to experience $12 \mathrm{~m}$ of displacement in January 1997. Also, there is evidence of other pronounced movement along the eastern margin, at the distinct exposed dip-slip faces along the upper and lower sections. The dip and plunge of the striations on these surfaces indicate that selective mobilization occurred when tailure initiated along the eastern margin and progressed in a SW direction. 
Cleveland Corral Landslide Activity: Jan-Apr 1998

During the above average precipitation of water year 1998 (an El Niño year), all of Cleveland Corral's sections mobilized (Figs. 33-35). Precipitation data from Pacific House were used prior to the installation of monitoring equipment at Cleveland Corral in March 1997. Data collected at both sites after March 1997 indicated similar intensity and duration of precipitation. Each of the three sections began moving at different times due to differences in slide phase, drainage, slope steepness, colluvium depth, and structural control, as discussed below.

Morphology of the Upper Section During Winter and Spring 1998

October and November 1997 rainfall was average, followed by a drier than average December. As the above average El Niño precipitation commenced, the water table and pore pressure levels began to rise. It is reasonable to assume that the drainage systems put in place by Caltrans reduced groundwater levels and pore pressures, and hence slowed slope movement.

By March 1998, intense rainfall and minor slope failure had produced the following geomorphic features on the upper section. $1.2 \mathrm{~m}$ deep gullies (Fig. 36), a shallow translational failure at the top of the toe bulge with a $20 \mathrm{~cm}$ high lateral scarp on the lower eastern margin, and a new $16 \mathrm{~cm}$ head scarp, which reappeared where the previous headscarp had been bladed smooth during mitigation efforts. The small translational slide, first seen as tension cracks in February (Figs. 37, 38), failed displacing the eastern section of the lower stone drain and producing a distinct margin on its eastern side (Figs. 39, 40). The displaced material eventually flowed onto the access road, which 


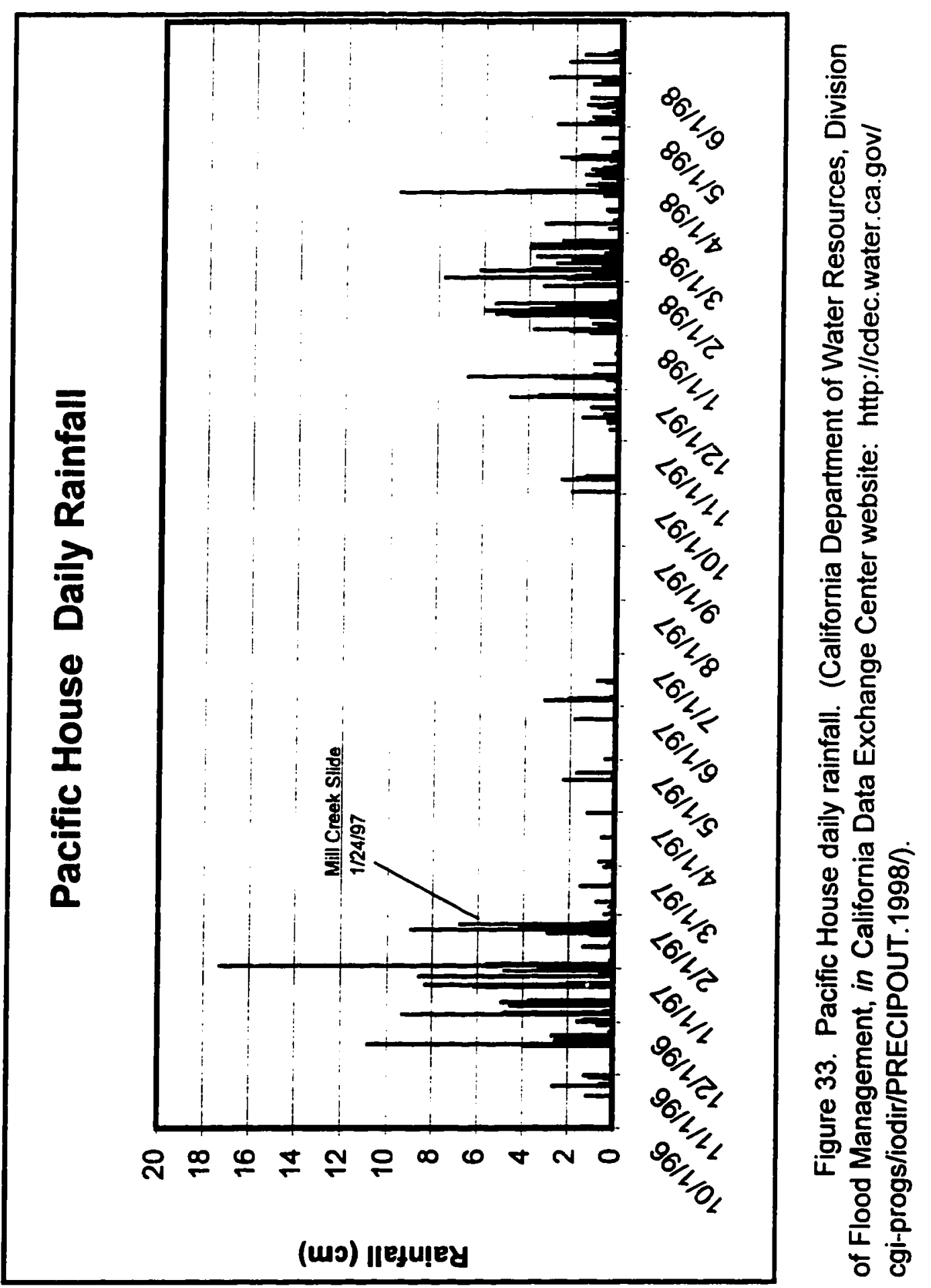



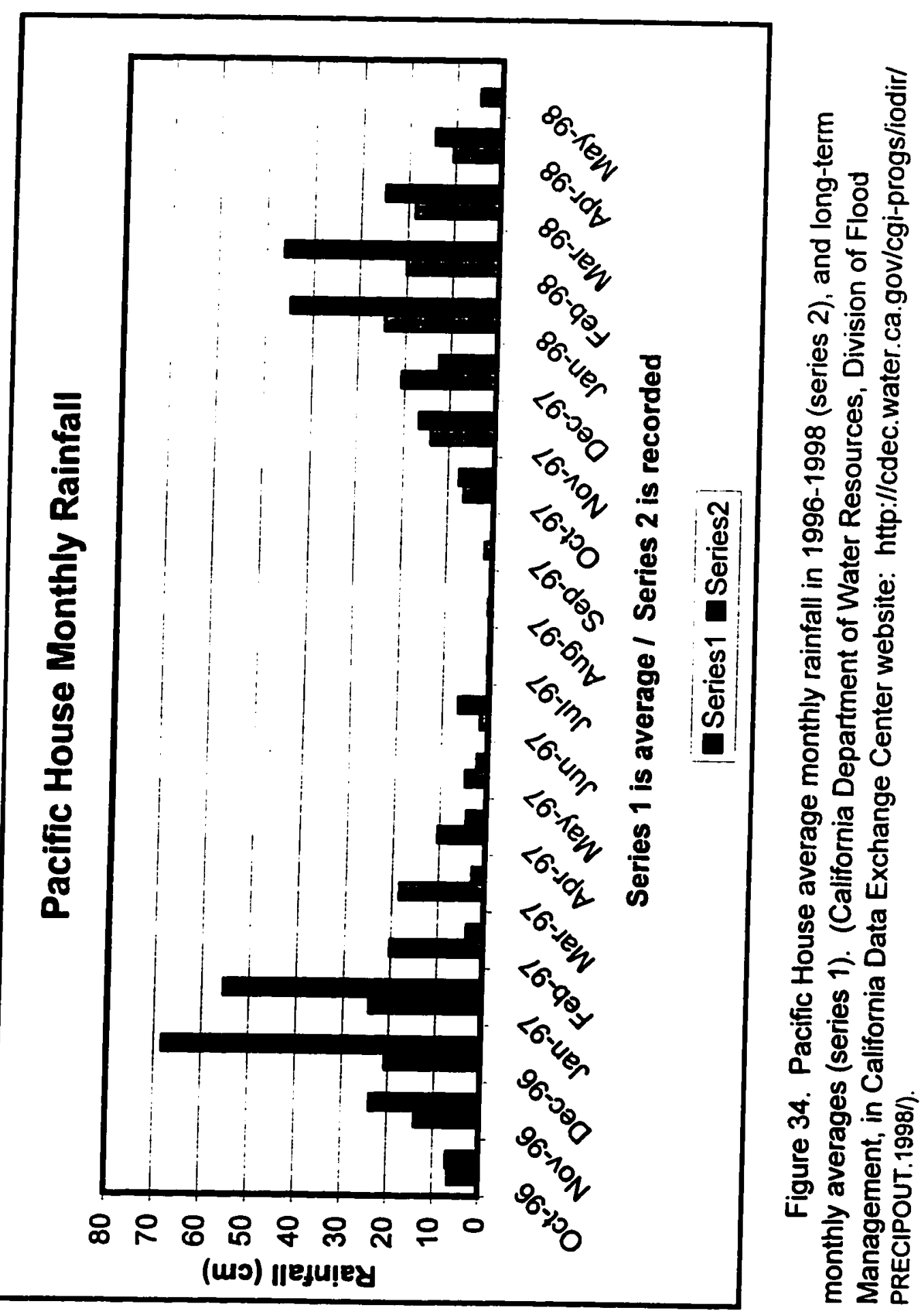

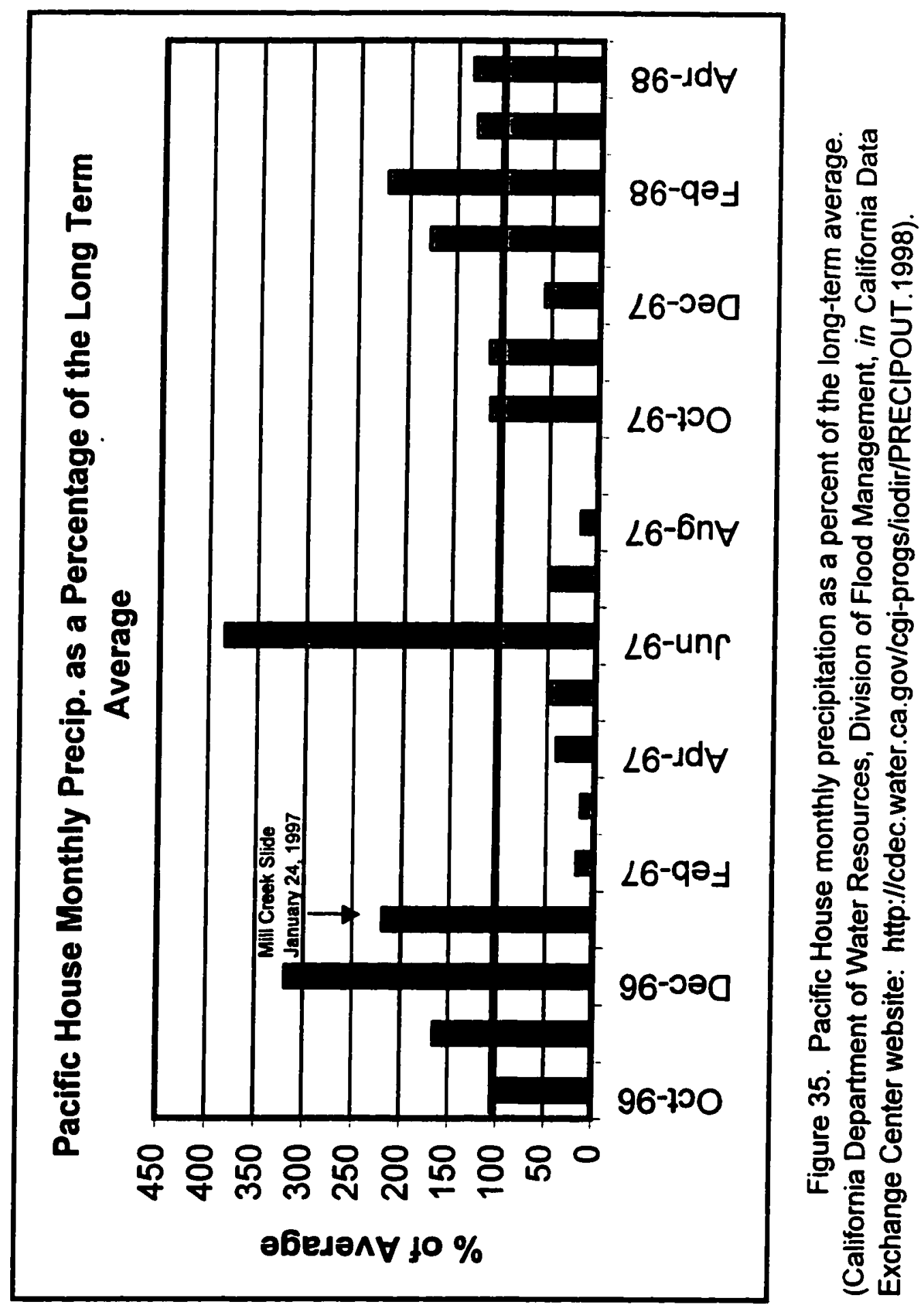
Figure 36. Upper section gullies. The upper section was bladed in October 1997. The black flex-pipe at left center, drains the discharge from the upper horizontal drain into the lower stone drain. Photo taken 2/9/98. View to the north.

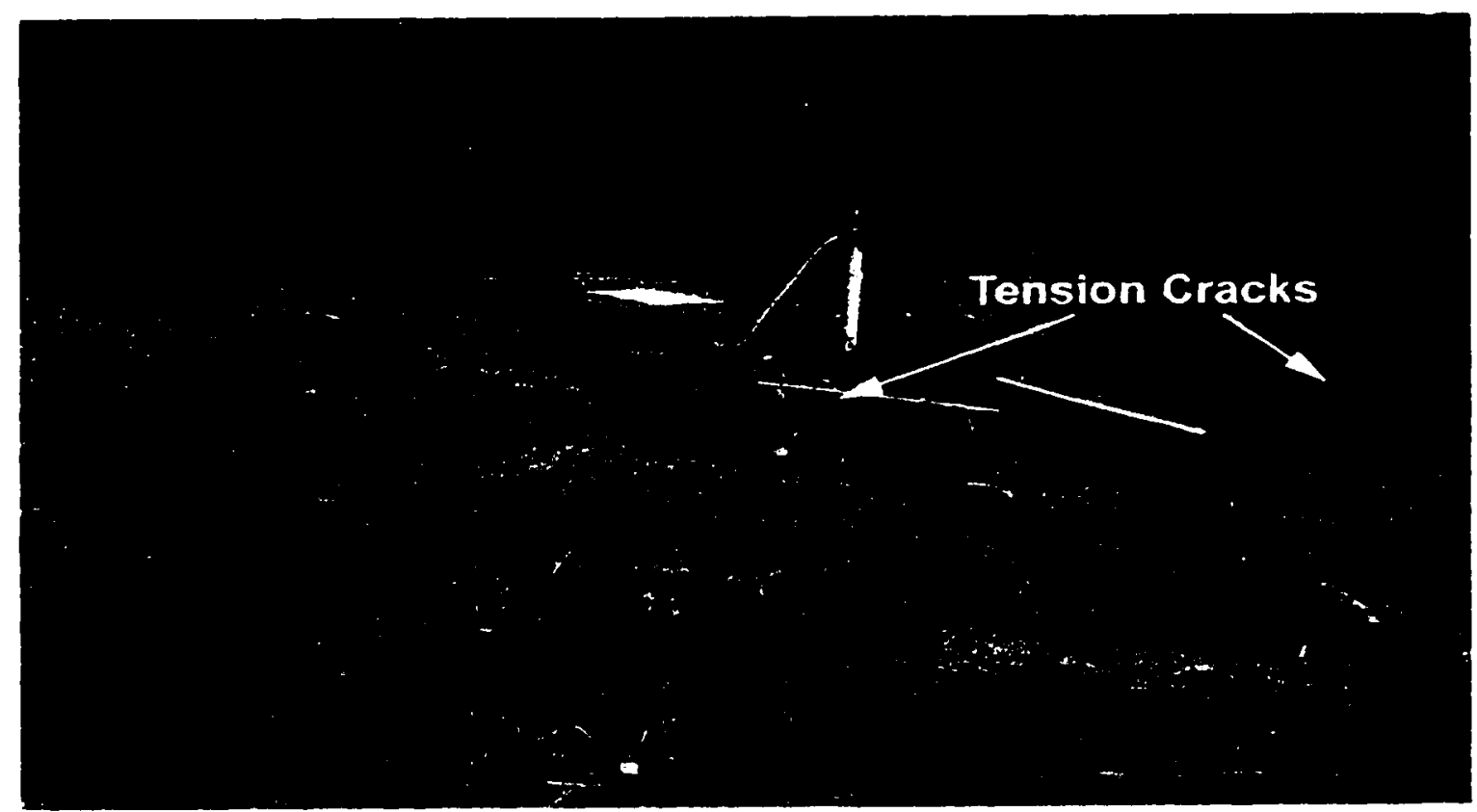

Figure 37. Tension cracks upslope from the upper section toe bulge and $0.5 \mathrm{~m}$ downslope from boring \#5. Photo taken $2 / 10 / 98$. View to the northeast. 


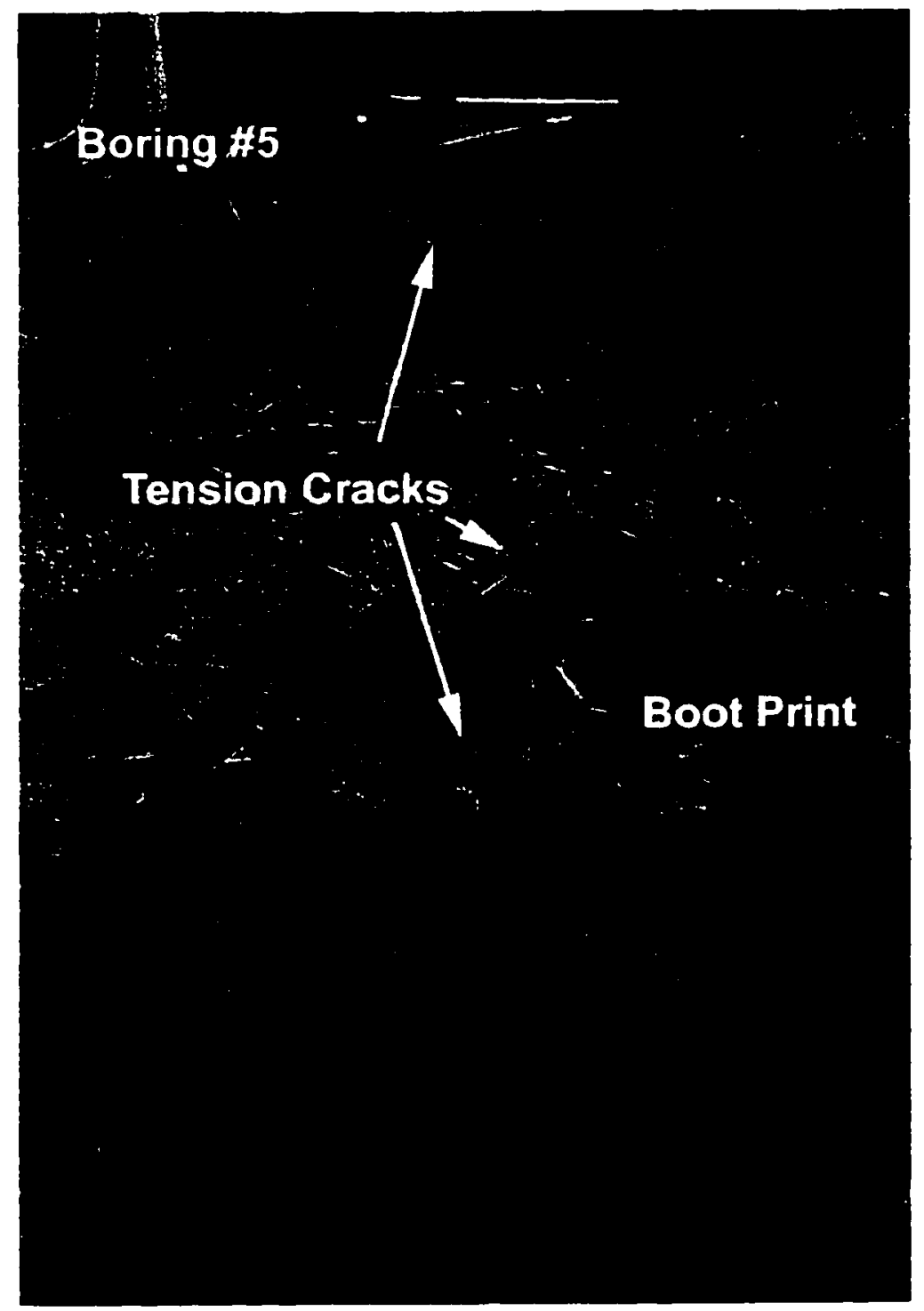

Figure 38. Tension cracks in the upper section. Photo taken $2 / 10 / 98$. 


\section{Shallow Failure}

Stone Drain

1
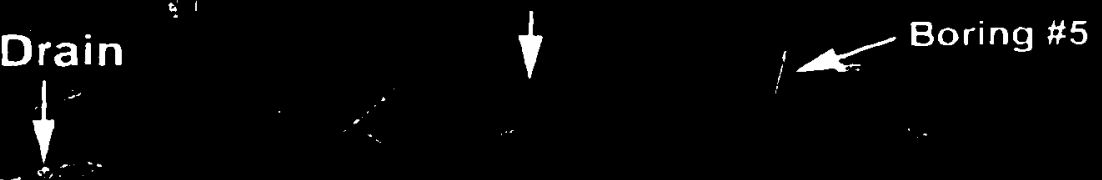

.

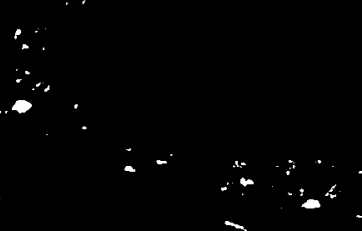

Figure 39. Slope failure on the upper section diplaces stone drain and exposes a monitor at boring \#5. Photo taken $3 / 10 / 98$. View to the west.

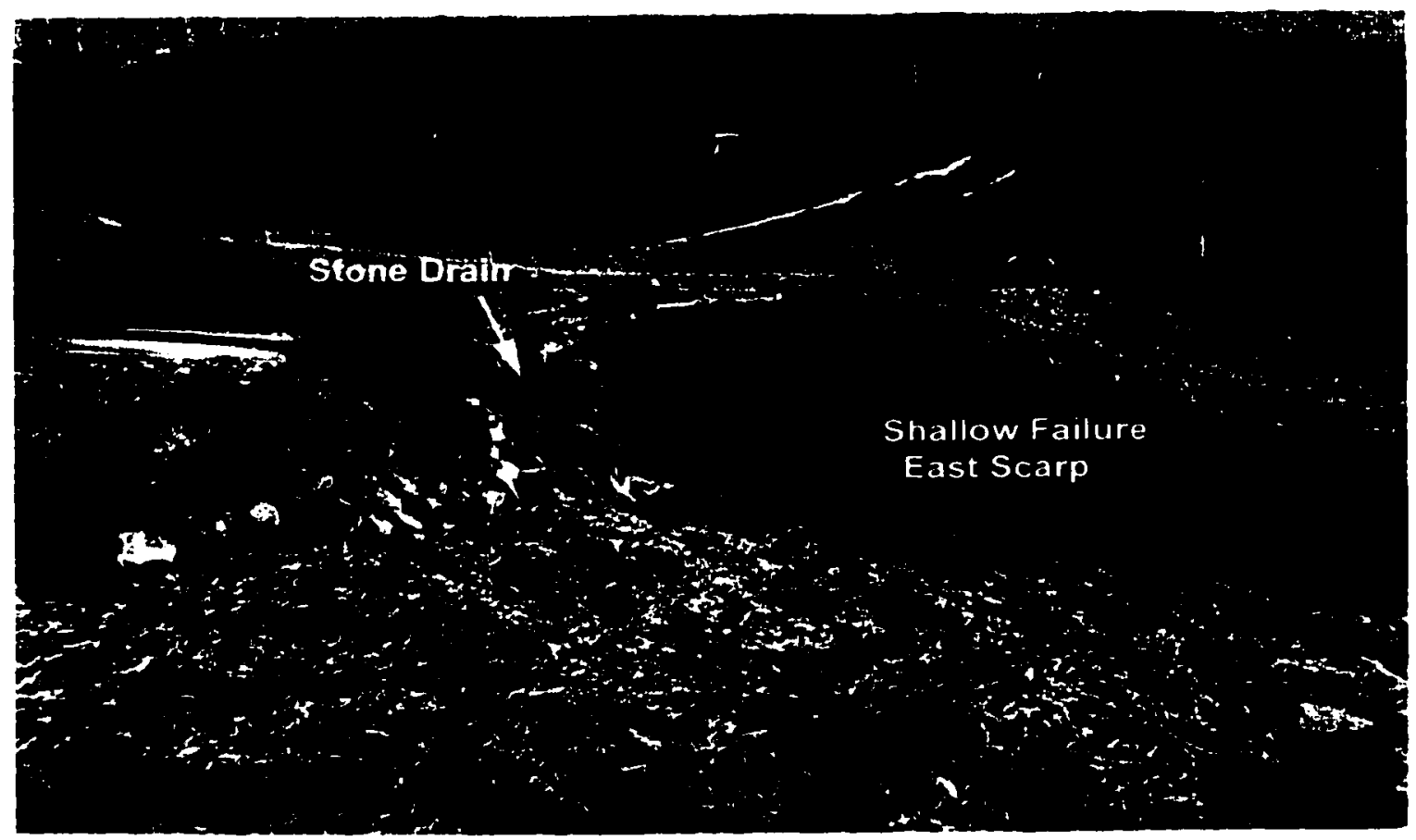

Figure 40. East margin of the upper section slope failure. Photo taken 3/10/97. 
was cut into the top of the upper section toe bulge. The stone drain and several wattles, which crossed the affected area, were useful in identifying the boundaries of this small slide. The stone drain and wattles developed bends at the boundaries between the stable and failed slopes (Fig. 41).

Overall slope movement for the upper section did not occur until the end of April 1998 (excluding the small shallow failure described above). Scraping of the surface and the installation of stone drains may have played a part in stabilizing the near-surface colluvium in the upper section. Subsurface drainage provided by the upper level of horizontal drains discharged as much as 1.95 cubic meters per hour (March 9, 1998). This may have contributed to the overall stability of the upper section. Monitoring data for the upper section show that the water table and pore pressures remained relatively low until late March 1998, when rainfall saturated the entire slope and overall upper section failure commenced (M. Reid, USGS, written commun., 1998). Localized emerging seepage at the ground surface was not observed until March 10 along the eastern margin of the upper section. The shallow failure (Fig. 39) that occurred in February 1998, however, was not enough to overcome the resisting force supplied by the large, stable, upper section toe bulge.

Both water table and pore pressures rose to their highest levels shortly after above average rainfall during the last week in March 1998. Three days after the rainfall ceased, pore pressures in the upper section quickly dropped due to the hydraulic gradient, minor infiltration above Ice House Road (caused by the covering of less permeable Mehrten material), and the high transmissivity of the colluvial material in the upper section toe 


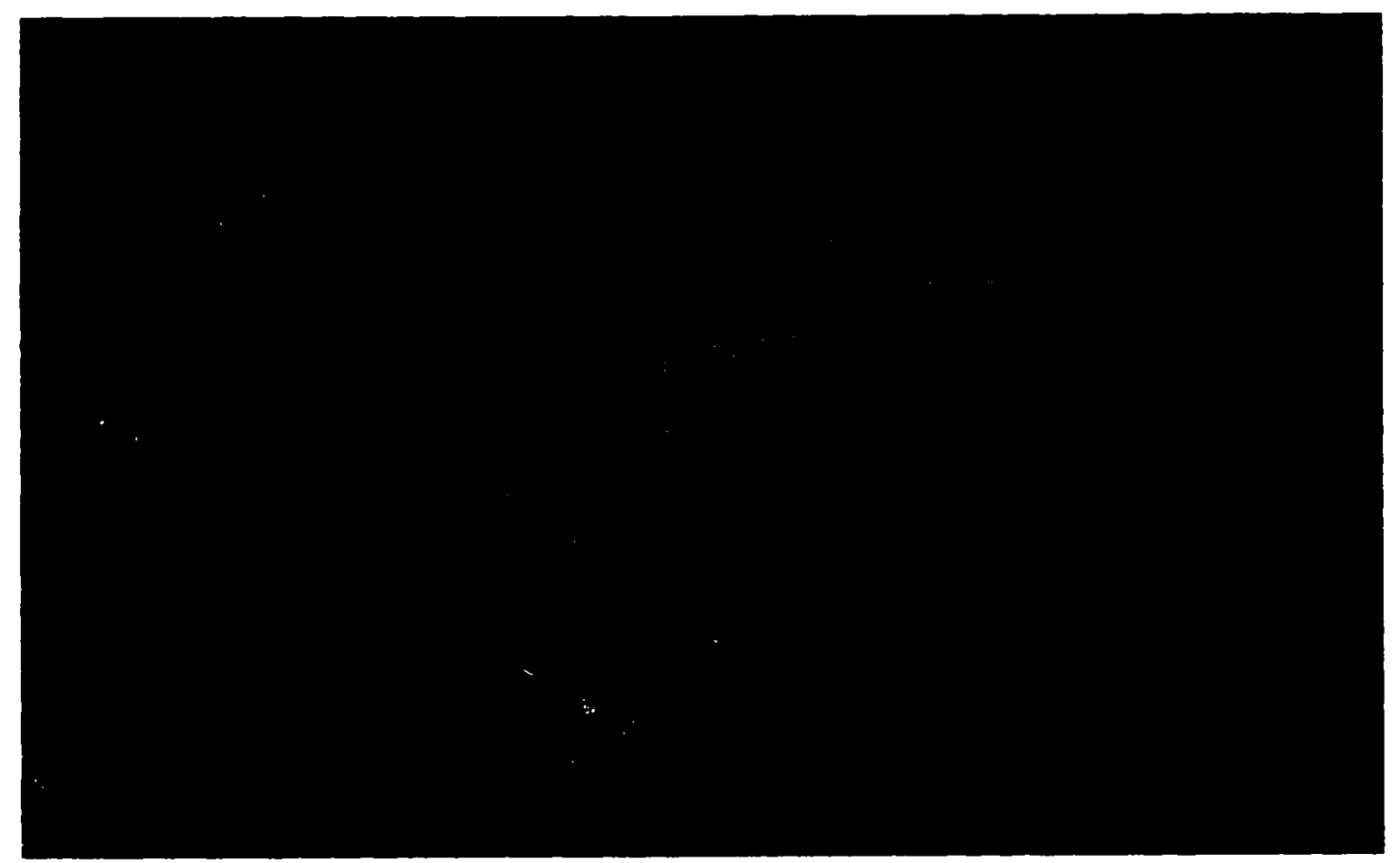

Figure 41. Previously straight wattles display deformation caused by the shallow slope failure shown in Fig. 39. Photo taken 3/10/98. View to the west. 
bulge. The water table receded, first in the upper section, slowly followed by the middle and lower sections. Anderson and Sitar's (1995) findings regarding the behavior of piezometric surfaces in colluvial slopes may explain this behavior. Typically it is observed that the saturated zone recedes, first on the upper reaches of the slope and that the topographic influence on groundwater seepage causes localized saturation. The duration of localized saturation increases with increased distance from the upper reaches of the slope. Johnson and Sitar (1990) found that high on the slope there was very little development of positive pore pressure because the colluvial slope was able to drain at a rate similar to the infiltration rate. This influence of groundwater seepage was observed at Cleveland Corral as the upper section was the last to move and the first to stop. the middle section was the second to move and second to stop, and the lower section was the first to move and the last to stop.

Morphology of the Middle Section During Winter and Spring of 1998.

The widest variety of monitoring sensors were installed by the USGS at the middle section of the Cleveland Corral slide. These monitors include two surface extensometers, two piezometers, a rain gage, and a geophone. The monitoring data provided insight towards understanding slope response to above average rainfall and the resulting high pore pressures. The water table and pore pressures increased quickly with each rain event and decreased slowly after the rain ceased. By January 17, the water table and pore pressures were being sustained at a high level by persistent rainfall.

Displacement began slowly around March 7,1998 and continued at a steady rate until the second week in April when the displacement rate increased due to sustained precipitation from March 21 to April 16. 
Sensitivity to rainfall becomes an increasing factor with increased piezometric surfaces and elevated pore pressures by groundwater seepage. These two factors decrease the factor of safety (FOS) to near 1.0 (a FOS of 1.0 is a transition point between a stable and unstable state. FOS $>1.0$ is stable and FOS $<1.0$ is unstable). At a certain point only small increases in the piezometric surface (due to rainfall or snowmelt) are required to decrease the FOS to less than 1.0, producing detectable slope movement. An example of this occurred on March 7. Piezometric surfaces and pore pressures were gradually decreasing (March 1-3), until a relatively small amount of rainfall (March 4, 6, and 7) caused the piezometric surface, and pore pressure to rapidly increase. On March 7, 1.25 $\mathrm{cm}$ of rainfall caused both shallow and deep pore pressures to noticeably increase and the middle displacement monitor recorded the initiation of slope failure. A total of $5 \mathrm{~cm}$ of displacement $(1.1 \mathrm{~cm} /$ day $)$ was recorded over the 4-day period. The rain ceased on March 8 followed by decreasing piezometric surface, stable pore pressures, and decreased movement rate at the middle lower displacement site (Figs. 42-45).

Morphology of the Lower Section During Winter and Spring of 1998.

The lower section was the first to resume movement in 1998 (Fig. 46). This may be due to a lack of internal drainage in the toe bulge as a result of recent movement. With the absence of monitors for the piezometric surface, field observations of seepage from around the base of the toe bulge were used to determine water table characteristics. By the second week in March, two of three extensometers located on the lower section toe had moved 1 to $1.5 \mathrm{~m}$ and appeared to be accelerating (M. Reid, USGS, written commun., 1998). 


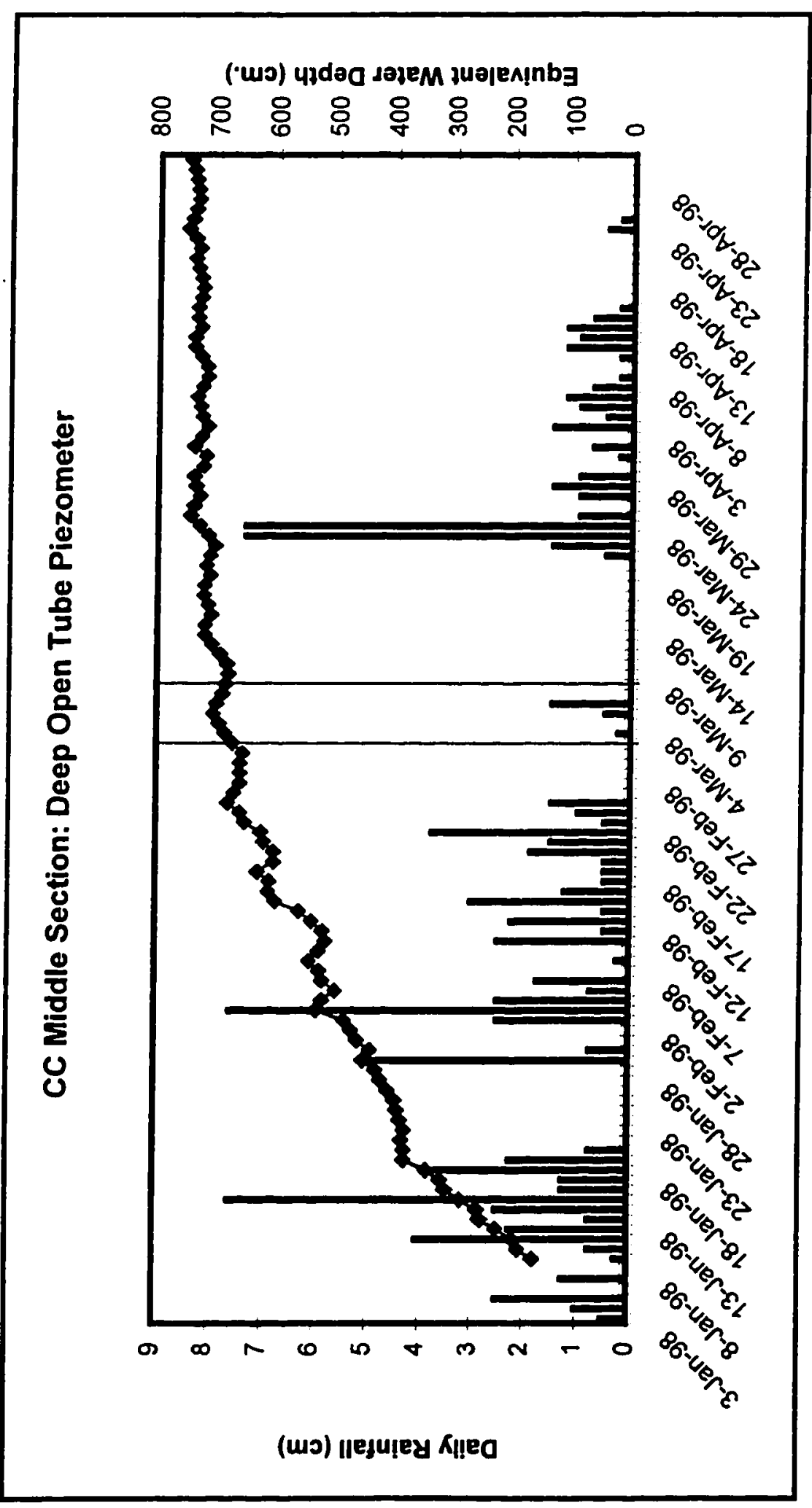

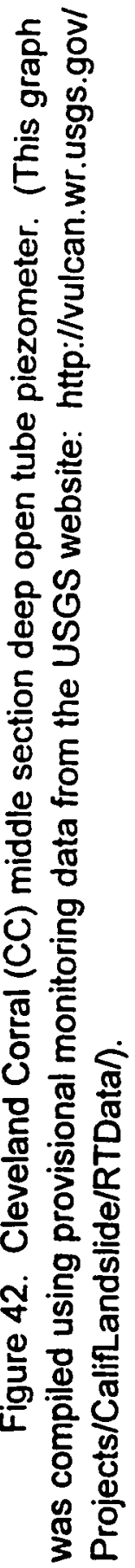




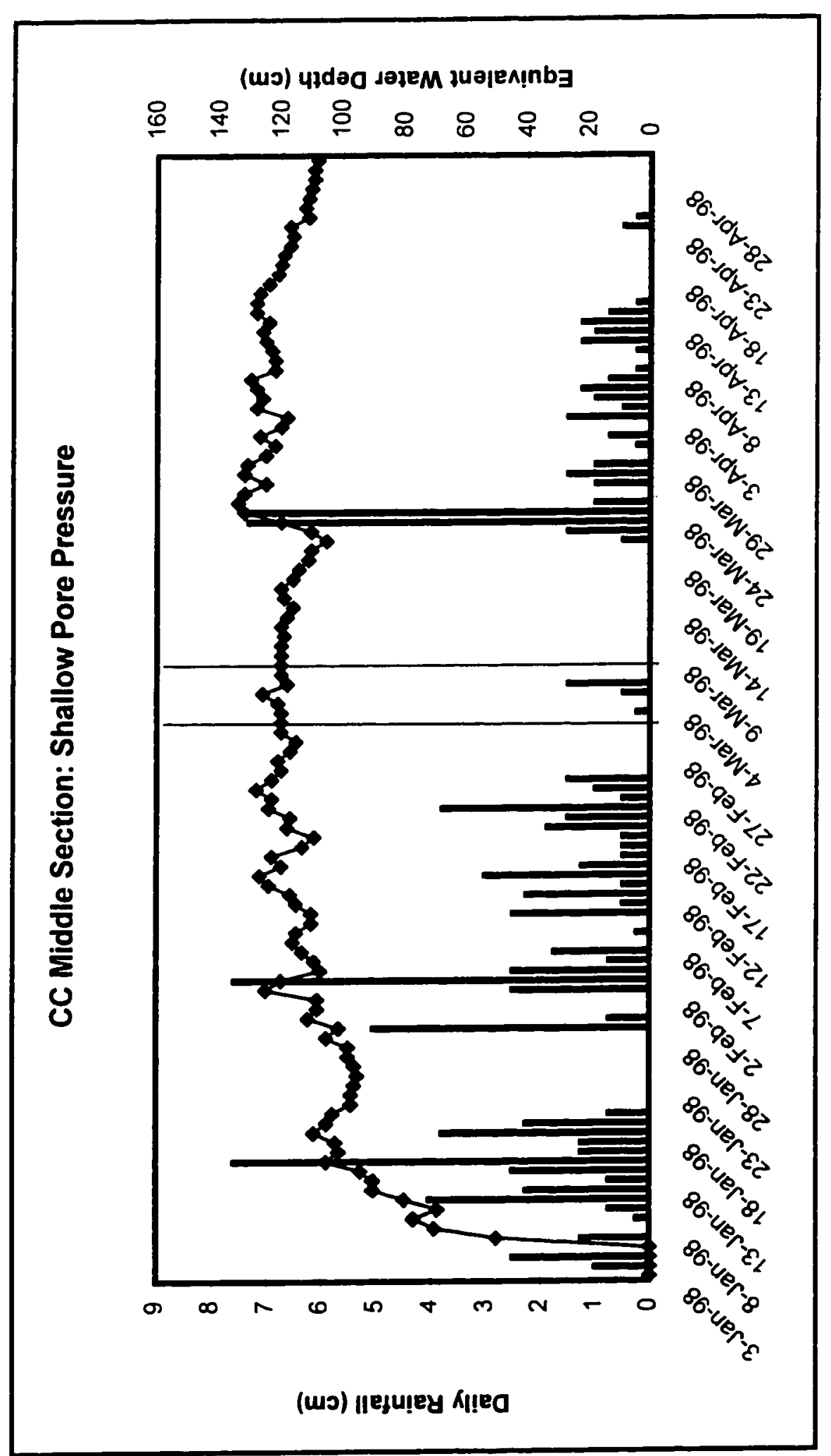

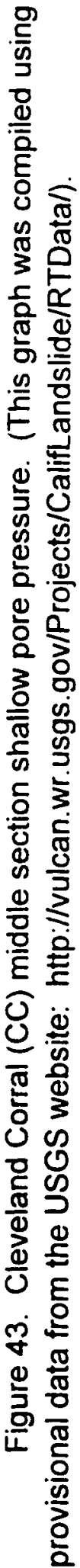



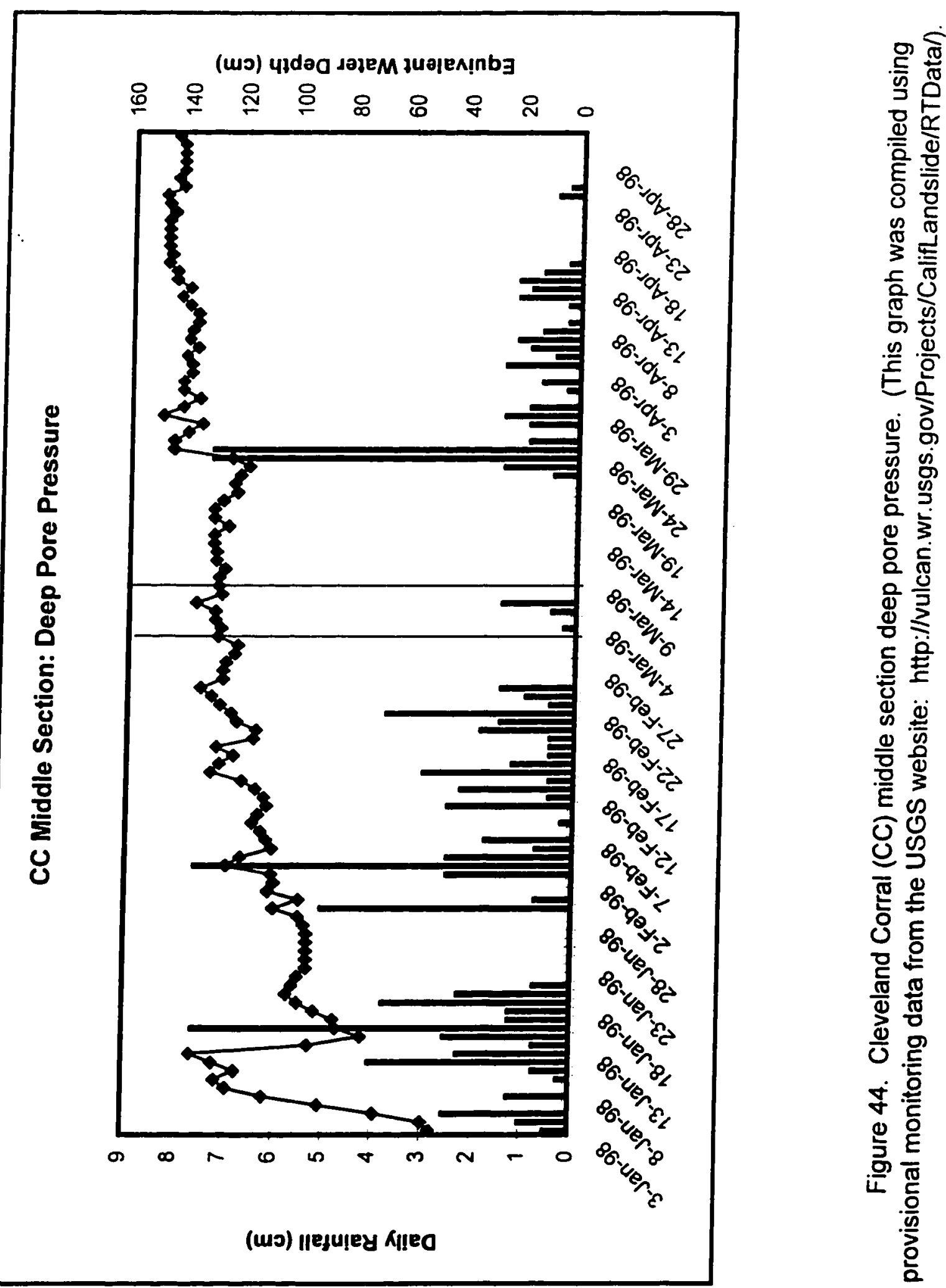

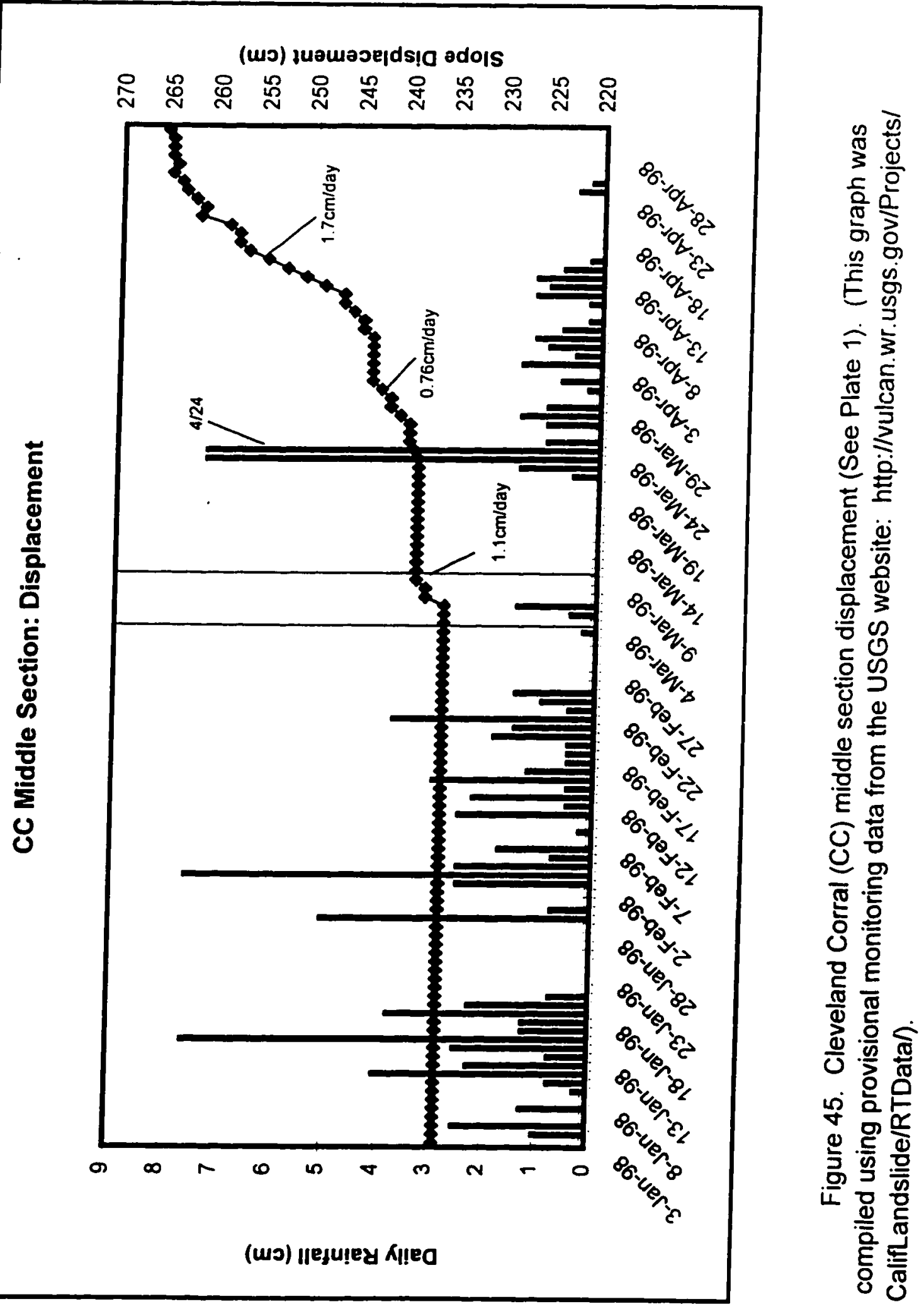

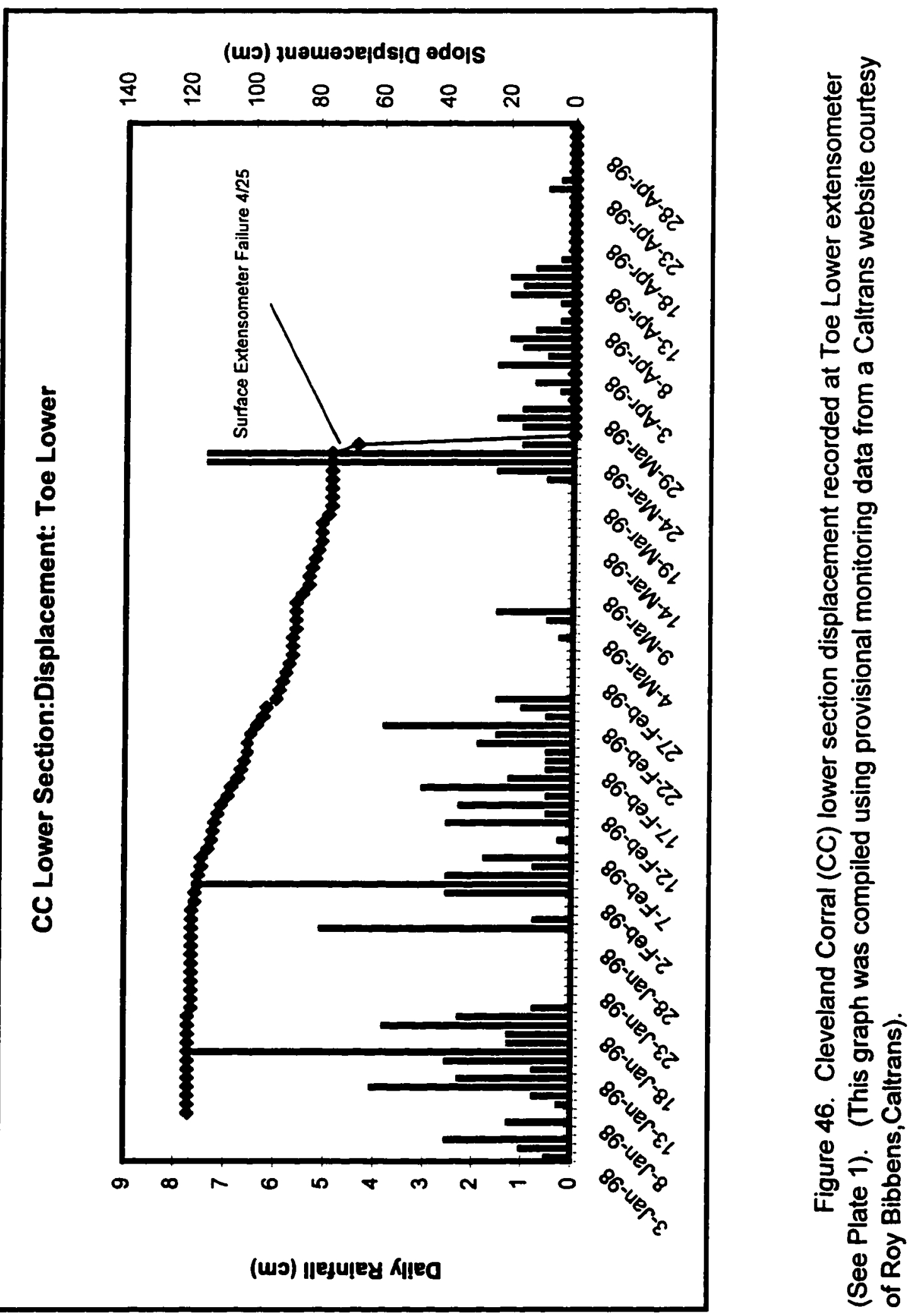
Between March and April, above average precipitation continued, and seepage was observed along the leading edge of the toe. A spring developed along the eastern margin, just above the toe bulge on the east side and surface water flowed around the toe into the natural drainage on the east side of the lower section. The slope displacement monitoring data displayed the sensitivity of the toe area, in that small rain events were immediately followed by slope displacement (Fig. 46). Several of the large pine trees directly in the path of the toe were cut down to prevent them from falling across power lines and Highway 50. Monitoring equipment of the lower side of the toe bulge malfunctioned due to instability and loss of integrity of the saturated colluvial material. Water was observed seeping from the downslope boundary of the toe on March 9, 1998. The toe bulge continued to advance, totaling $5.6 \mathrm{~m}$ (18.5 feet) of movement by the end of June 1998 (M. Reid, USGS, written commun., 1998). 


\section{LIMIT EQUILIBRIUM ANALYSIS}

\section{Profile}

The topographic profile was generated from transit line A-A', shown on the USGS 1-meter contour map of Cleveland Corral (Plate 1). The transits were selected to offer a profile depicting the sections as if they were aligned in a straight, north-south line. This allows the geomorphic features of each section to be included in the entire geologic profile. The geologic profile was determined using field observation, surface feature mapping, well logs, and preliminary seismic results.

The water table profile was developed from field observation of seepage, springs, and measurements taken in borings during February and March 1998. Piezometric surface and pore pressure monitoring data were used to determine the degree of saturation of each section during saturated, wet, and dry conditions. For saturated conditions, the saturated zone extended from the colluvium/bedrock contact to the ground surface. For dry conditions, the piezometric surface was determined to be at the colluvium/bedrock contact. Under wet conditions, the upper section piezometric surface was determined to be halfway between the colluvium/bedrock contact and the colluvium surface. Under wet conditions the middle section piezometric surface is located at the top of the groundwater table, which occupied the lower two thirds of the colluvial layer. Under wet conditions, the lower section piezometric surface is located at the top of the lower three quarters of the colluvial layer. 
The failure surface profile was determined to be the colluvium/bedrock interface based on well logs and preliminary USGS seismic profiles (Figs. 25-29). The actual depth and character of the failure surface for the middle section is unknown, and assumed to be consistent with those found through boring and seismic surveys conducted at other sections. A depth of colluvium of 9-11 m was used for the upper and lower sections, and 9-14 $\mathrm{m}$ for the middle section.

\section{Angle of Friction (phi) and Cohesion}

Internal angle of friction values were determined from blow counts and direct shear tests. The blow counts were taken during upper section borings on October 15, 1997. Direct shear tests were performed on samples collected on August 24, 1998 from the upper section at the base of the new scarp shown in Figure 39, and from the lower section at the base of the dip-slip surface along the east margin (Plate 1). Cohesion values were determined from direct shear tests. All values obtained from field samples represent dry conditions. Initial values for wet and saturated conditions were obtained from representative values of similar material (Romie, 1990).

\section{Methodology}

The goal of the limit equilibrium analysis was to determine if results of analyses using reasonable values for the shear strength and cohesion at the failure surface during wet and saturated conditions were consistent with the slope stability/instability observed on-site. 
Internal angle of friction and cohesion for simple computer models and hand calculated infinite slope models were varied during wet and saturated conditions to provide FOS values that were general agreement with on-site observations and monitoring data. Pore pressures at the failure surface were based on the height of the piezometric surface above the failure plane for each section during each water table condition.

The Slope Stability Software Analysis Package (PCSTBL) program was used in conjunction with STBL EDITOR (STED) (Van Aller, 1994) to provide a visual depiction of the most probable failure surface in the slope profile for each section under various conditions. Inputs to the model included a topographic surface profile, a geologic profile, and a water table profile.

The Sliding Block function of the PCSTBL program calculated the failure planes most likely to occur between two designated blocks underlying a section. The blocks are 2-dimensional, 1-foot high boxes with all four sides composed of straight lines. They were placed along the failure plane of each section, under each water table condition. The failure planes are plotted on the section profile and the FOS of each failure plane is listed in order of ascending FOS. The failure plane with the lowest FOS (least stable) is highlighted on the section profile (Appendix A).

The Specified Surface function of the PCSTBL program produces a single FOS for a failure plane specified by the user. For all sections the line represents the failure surface along the colluvium/bedrock contact (Appendix A). The results of both methods were compared, and a set of phi and $\mathrm{C}$ values for wet and saturated water table conditions, for each section was determined. The results of all models are located in Tables 1 and 2. 


\section{Factor of Safety}

In simple terms, the factor of safety of a slope can be found by dividing the resisting forces by the driving forces. Therefore a FOS of 1.0 is a transition point between a stable and unstable state. FOS $>1.0$ is stable and FOS $<1.0$ is unstable. The computer (PCSTABL) and infinite slope results for all sections and ground water conditions were in close agreement with field observations (Table 1). PCSTABL FOS results were higher because PCSTABL's Simplified Janbu method determines inter-slice forces for the irregular specified surfaces and applies a correction factor which increases the FOS depending on the ratio of depth to length for each slice. Also the Simplified Janbu method is more sensitive to vertical forces which vary with saturation conditions. Infinite slope analyses ignore the driving forces of the upper end of the slope and the resisting forces of the lower end. Since the resisting forces at Cleveland Corral are significant, the infinite slope results are generally more conservative than the PCSTABL results. The PCSTABL upper section results were $20-30 \%$ higher and lower section results were $10-15 \%$ lower than infinite slope results (Table 2).

TABLE 1. COMPARISON OF FOS DETERMINED FROM INFINITE SLOPE, COMPUTER MODEL, AND MONITORING DATA.

\begin{tabular}{|l|c|c|l|}
\hline $\begin{array}{c}\text { Overall GW } \\
\text { Level }\end{array}$ & $\begin{array}{c}\text { Infinite } \\
\text { Slope }\end{array}$ & $\begin{array}{c}\text { Computer } \\
\text { Model }\end{array}$ & \multicolumn{1}{|c|}{ Monitoring Data } \\
\hline Saturated & $0.64-0.77$ & $0.60-0.98$ & $<1.0$ \\
\hline Wet & $0.85-0.90$ & $0.72-1.31$ & $<1.0$ (Lower Section) \\
& & & $\begin{array}{l}\geq 1.0 \text { (Middle \& Upper } \\
\text { Section) }\end{array}$ \\
\hline Dry & $2.71-3.21$ & $2.81-4.75$ & $>1.0$ \\
\hline
\end{tabular}


TABLE 2. FACTOR OF SAFETY RESULTS FOR EACH SECTION USING PCSTBL AND INFINITE SLOPE METHODS DURING SATURATED, WET, AND DRY CONDITIONS.

\begin{tabular}{|c|c|c|c|}
\hline \multirow[t]{2}{*}{ STED PCSTBL } & Sat & Wet & Dry \\
\hline & phi/C & phi/C & phi/C \\
\hline Sliding Block Method & FS & FS & FS \\
\hline \multirow{2}{*}{\begin{tabular}{|l|} 
upper section \\
\end{tabular}} & $16 / 300$ & $16 / 300$ & $28 / 1090$ \\
\hline & 1 & 1.3 & 4.7 \\
\hline \multirow[t]{2}{*}{ middle section } & $15 / 400$ & $15 / 400$ & $26 / 1830$ \\
\hline & 0.8 & 0.9 & 3.1 \\
\hline \multirow[t]{2}{*}{ lower section } & $15 / 400$ & $15 / 400$ & $26 / 1830$ \\
\hline & 0.6 & 0.7 & 2.6 \\
\hline \multicolumn{4}{|c|}{ Specified Surface Method } \\
\hline \multirow[t]{2}{*}{ upper section } & $16 / 300$ & $16 / 300$ & $28 / 1090$ \\
\hline & 0.9 & 1 & 4 \\
\hline \multirow{2}{*}{ middle section } & $15 / 400$ & $15 / 400$ & $26 / 1830$ \\
\hline & 0.8 & 0.9 & 4 \\
\hline \multirow[t]{2}{*}{ lower section } & $15 / 400$ & $15 / 400$ & $26 / 1830$ \\
\hline & 0.6 & 0.8 & 3.2 \\
\hline \multicolumn{4}{|c|}{ INFINITE SLOPE METHOD } \\
\hline \multicolumn{4}{|c|}{ Parallel Seepage (Table Method) } \\
\hline \multirow[t]{2}{*}{ upper section } & $16 / 300$ & $16 / 300$ & $28 / 1090$ \\
\hline & 0.7 & 0.9 & 2.7 \\
\hline \multirow[t]{2}{*}{ middle section } & $15 / 400$ & $15 / 400$ & $26 / 1830$ \\
\hline & 0.8 & 0.9 & 3.2 \\
\hline \multirow[t]{2}{*}{ lower section } & $15 ! 400$ & $15 / 400$ & $26 / 1830$ \\
\hline & 0.8 & 0.8 & 3.2 \\
\hline \multicolumn{4}{|c|}{\begin{tabular}{|l} 
Parallel Seepage (Slope Ratio Method) \\
\end{tabular}} \\
\hline \multirow[t]{2}{*}{ upper section } & $16 / 300$ & $16 / 300$ & \\
\hline & 0.7 & 0.9 & \\
\hline \multirow[t]{2}{*}{ middle section } & $15 / 400$ & $15 / 400$ & \\
\hline & 0.8 & 0.9 & \\
\hline \multirow[t]{2}{*}{ lower section } & $15 / 400$ & $15 / 400$ & \\
\hline & 0.7 & 0.8 & \\
\hline \multicolumn{4}{|c|}{ Emerging Seepage (Slope Ratio Method) } \\
\hline \multirow[t]{2}{*}{ upper section } & $16 / 300$ & & \\
\hline & 0.6 & & \\
\hline \multirow[t]{2}{*}{ middle section } & $15 / 400$ & & \\
\hline & 0.7 & & \\
\hline \multirow[t]{2}{*}{\begin{tabular}{|l} 
lower section \\
\end{tabular}} & $15 / 400$ & & \\
\hline & 0.7 & & \\
\hline
\end{tabular}




\section{SUMMARY OF RESULTS}

\section{$\underline{\text { Geology }}$}

The erosion of the north-south trending antiform seen in Figure 5 has exposed a section of lower Paleozoic quartz-mica schist. Landslides occur along the contact between this unit and the predominant Cretaceous granitoids. The Mill Creek slide, which closed Highway 50 for 27 days in January/February 1997, forms the eastern boundary of the quartz-mica schist exposure, and the current Cleveland Corral slide forms the western boundary. This contact creates a zone of weakness along the slopes of Cleveland Corral.

At Cleveland Corral, the contact affects drainage by capturing and channeling seepage along the eastern margin of the slide. Evidence for this was observed near the end of the dry season in October 1998 at horizontal drain sites. Only those drains located on the eastern side of the slope produced discharge. During wet periods, seepage emerged along the eastern margin of upper and middle sections and flowed along the eastern margin of the lower portion of the lower section. This localization of ground water along the eastern margin causes higher pore pressures and localized slope failures, with striated dip-slip surfaces along the upper and lower sections' eastern margins. Along the eastern margin of the middle section, distinct boundaries can be observed. These features indicate selective mobilization and initiation of slope failure for the upper and lower sections along the east margin. 


\section{Summary of Slide Movements}

Field observations and monitoring data revealed that, between January-June 1998, the lower section resumed movement on February 4, and the middle section resumed movement on March 7. The shallow, upper section failure occurred during the first week of March, however, the stable and upper section toe bulge moved very little in 1998.

Sustained rainfall commenced in January with $175 \%$ of average. Sixteen of the first 20 days of the month received rainfall. With infiltration exceeding drainage, piezometric surfaces in all sections rose quickly. In the middle section, monitors showed that by the end of January the piezometric surface had reached half of what would later become its maximum elevation. The piezometric surface increased rapidly during prolonged and intense rain events. Between rain events the rate that the piezometric surface rose, slowed and pore pressures stabilized in response to the drainage and downward percolation of the perched water tables, which increased the water table from the bedrock contact, upwards into the colluvial layer. Ground water from the upper section and areas higher in the hydraulic gradient sustained the rising piezometric surface during brief dry periods.

February produced 20 days of rainfall, where the longest dry spell was the last 4 days of the month. February rainfall was $225 \%$ of normal and the wettest month of 1998 for the site. The middle section piezometric surface continued to climb at the same average rate as in January, and receded during brief dry periods and light rain. Pore pressure fluctuations decreased as the piezometric surface approached the ground surface because of the diminishing effect of perched water tables on pore pressures. As pore 
pressures reached higher levels, FOS values decreased towards 1.0 increasing the sensitivity to additional rainfall.

The first slope failure of 1998 occurred in the lower section where monitoring consisted of three extensometers, all of which registered movement in the first week of February. On February 3,2.5 cm of rain fell. On February $4,7.6 \mathrm{~cm}$ of rain fell and the monitor designated Toe Lower, located on the southern side of the lower section toe bulge, failed after indicating very little movement (Fig. 46). On February 9, seepage was observed all along the leading edge of the lower section toe bulge. The activation of the lower section is due to its position in the hydraulic gradient. Once significant and sustained rainfall commenced, the lower section received an almost constant influx of ground water resulting from ground water seepage from areas higher in the hydraulic gradient. After the pore pressures increased, the FOS reached $<1.0$, and translational debris sliding began. Further rainfall events of at least $2.5 \mathrm{~cm}$ caused the pore pressure to rise, further dropping the FOS, resulting in a sudden initiation of failure or increased rate of failure. This sliding motion along the colluvium/bedrock failure plane caused the dense material to dilate, thereby increased pore volumes. With the aissence of readily available pressurized pore water (because of low hydraulic conductivity resulting from the high-density colluvium) the pore pressure dropped, increasing the FOS, and restoring the section to a very slow rate of movement. Alternatively, when there is pore water under pressure and the slope is sufficiently steep, as was the case with Toe Lower (Fig. 46), the colluvium loses cohesion, structural integrity, and becomes a debris flow. 
March rainfall was 125 percent of normal. During the first 22 days, there were only 3 light rain days, the heaviest of which was $1.5 \mathrm{~cm}$ (Fig. 42). The last 9 days produced 8 days of rain, 7 of which were greater than $1.3 \mathrm{~cm}$, and 2 consecutive days each producing $7.6 \mathrm{~cm}$ of rain. The piezometric surface declined from February 24 until the first light rains of March 4, 6, and 7. On March 7, middle section monitors recorded a peak piezometric surface, along with sudden spikes for deep and shallow pore pressures. Initiation of slope movement occurred at the middle section at a rate $1.1 \mathrm{~cm} /$ day for 4 days. The responses to relatively light rain indicate pore pressures are elevated to the point where the FOS is <1.0. Significant rains returned on March 21. March 22 and 23 produced $7.6 \mathrm{~cm}$ of rain each, causing the piezometric surface to peak, and the shallow and deep pore pressures of the middle section reached new high levels. The middle section resumed movement at $1.0 \mathrm{~cm} /$ day and by March 25 the second of the three extensometers in the lower section failed.

Fourteen of the first 16 days in April produced 140 percent of normal rain for the month. This, combined with the significant rains at the end of March, resulted in a 26-day rainy period consisting of 22 rain days. Between March 25 and 30 , the middle section monitors showed a 5 day period with $0.76 \mathrm{~cm} /$ day movement followed by a 5 to 6 day period of little or no movement. This was the result of the debris slide lacking sufficient slope and/or sustained pore pressure to provide continued movement. By April 10, the persistent rains and groundwater seepage again increased the piezometric surface, and pore pressure, lowering the FOS, whereby the middle section debris slide reached its highest sustained rate of $1.65 \mathrm{~cm} /$ day (Fig. 45). It was during this period that the upper section pore pressures increased to the point where a slow slope movement rate was first recorded. 
Field observation of the lower section revealed that seepage continued from the leading edge of the toe indicating saturated conditions. A $<1.0$ FOS was evident due to approximately $4.9 \mathrm{~m}(16 \mathrm{ft})$ of toe bulge movement by the end of April. During the last 10 days of April only $1.0 \mathrm{~cm}$ of rain was recorded, along with a decrease in piezometric surface, deep and shallow pore pressures, and a reduction $(0.5 \mathrm{~cm} /$ day $)$ of movement rate in the middle section. Despite the lack of rainfall, the lower section continued to receive enough groundwater to maintain a creep rate that advanced the lower toe a total of $5.6 \mathrm{~m}$ (18.5 ft) (M. Reid, USGS, written commun., 1998) by the end of June.

\section{$\underline{\text { Mechanics }}$}

The observations listed above provide clues to the hydrologic and mechanical forces controlling each section of the slide during dry, wet, and saturated conditions. The geomorphology of the upper section indicates that it has been stable for a minimum of 60 to 70 years. Large upright trees on the toe bulge are approximately the same size as stumps with 60 to 70 annual rings. This means that the southern portion of the upper section is stable and has developed an adequate drainage system to convey excess groundwater to the lower sections. The northern portion of the upper section has moved during the past 2 years, does not have adequate drainage, and is clearly unstable during saturated conditions. In Figure 47, the head scarp and two minor scarps, which increase in size downslope, can be seen. These features were bladed smooth in November 1997. The shallow slide of March 1998, at the site with $12 \mathrm{~m}$ (39 ft) of movement in 1997 , demonstrated that the northern portions of the upper section are much less stable than the toe bulge. 


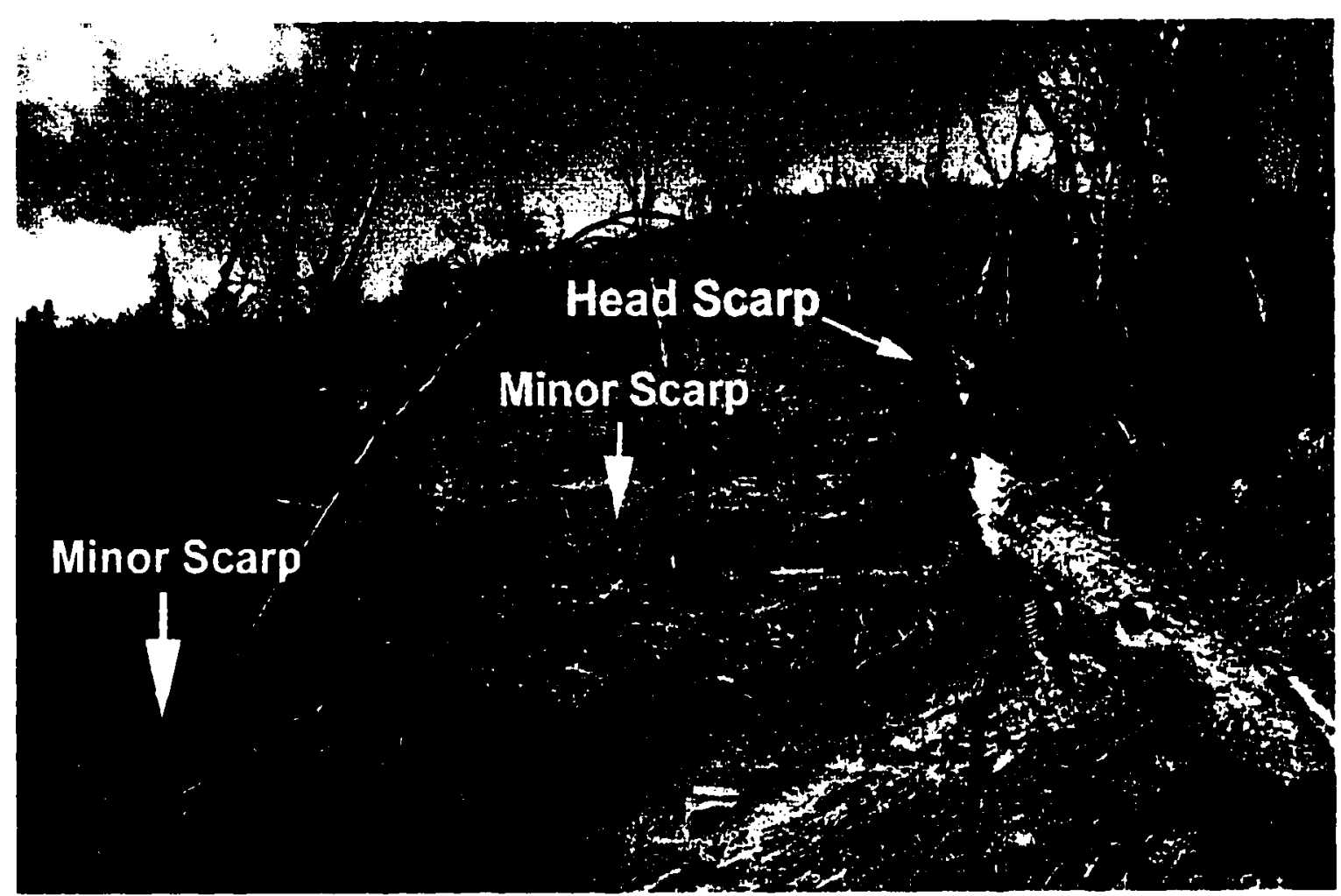

Figure 47. Upper section head scarp and two minor scarps. Horizontal drains were installed into the face of the middle scarp, draining the head scarp area. This entire area was bladed smooth to slow surface water infiltration. The red minor scarp in the lower left, is the site of the shallow surface failure seen in figure 39 . The linear feature in the foreground is a plastic pipe which houses a surface extensometer cable. Photo taken $4 / 2 / 97$. View to the north. 
During wet and saturated conditions these smaller slides continue to load the toe bulge, increasing the driving forces, and the possibility of an overall upper section failure. The direction such a failure will take depends on the buttressing effect of the talus pile, located immediately downslope in the path of the toe bulge. The talus pile could divert the debris to a more southerly route toward the middle section. Currently mass wasting is removing the southwestern side of the talus pile into the steep gully to west of the slide (Fig. 11). Therefore, mass wasting is removing the upper section's resisting force, and continued northern portion failures add to the driving forces affecting the toe bulge of the upper section.

Slope movement within the middle section of the slide was relatively minimal and not recognized by field observation. However, the middle section was host to the majority of monitoring devices, and therefore provided the bulk of the data required to establish the slope profile models. Pervasive tension cracks in the middle section allow surface runoff to infiltrate the colluvial layer and hasten the buildup of pore pressures. Although pore pressures did increase rapidly and initiate slope movement, the highest rate of movement ( $1.1 \mathrm{~cm} /$ day) on April 20, never lasted more than 2 days before returning to an average creep of $0.8 \mathrm{~cm} /$ day. This can be attributed to an adequate drainage system in this section. The middle section also receives additional groundwater input due to seepage from the upper section, and therefore sustains high pore pressures for several days after a rainy period. This section, like the upper section's toe bulge, has numerous large, upright trees in place, which indicates that the middle section has been relatively stable for the past 60 to 70 years. 
The middle section should continue to exist as an individual block in the Cleveland Corral slide. With the exception of accumulation from the upper section and/or other small slides from the ridge located to the east of the middle section's northern portion, it currently has no increasing driving forces. The southern end of the middle section is the head scarp of the lower section. This is defined by a topographic break in slope and can be seen on the USGS seismic profile. Due to the less-steep angle of the southern portion of the middle section, the upslope migration of the lower section head scarp should be very gradual.

The lower section is a translational debris slide that failed during the winter or spring of 1996. Its head scarp is located at a break in slope as described above, and the distinct dip-slip scar along the east margin can be seen in the color oblique aerial photos (Fig. 10). This translational debris slide was initiated at the head scarp and along the eastern margin. Elevated pore pressures along the failure plane and the eastern margin, were caused by above average rainfall and along the east margin were likely the result of localized groundwater seepage in the zone of weakness created by the geologic contact. Other factors include a loss of slope stabilization as a result of tree-root decay 4 years after the 1992 Cleveland Corral Fire. This diminished the resisting force along the slope and allowed the northern portion and east margin of the lower section to fail along the steep bedrock surface below the head scarp. As a result of such recent movement, the toe has no significant drainage system. Saturation along the base of the toe bulge was evident as seepage occurred from its leading edge, and continued weeks after significant rain events. This lack of drainage and the ground water from upslope influenced the failures at two of the three surface extensometers and $5.6 \mathrm{~m}(18.5 \mathrm{ft})$ of total displacement in 1998 . The 
presence of numerous large, live trees, did not stop the advance of the leading edge of the toe. If above average rainfall occurs before this section reestablishes a drainage system it will continue moving towards and reach Highway 50.

\section{Limit Equilibrium Analysis}

The limit equilibrium analyses were performed to calculate FOS and obtain visual representations of the failure planes for a variety of scenarios. The PCSTBL program required profile inputs to build a framework for each section of the slide. Once each section was established with a longitudinal profile, piezometric surface, pore pressure, soil total weight, and saturated weight, the internal angle of friction and cohesion were inputted and modified to provide results that matched the observed slope behavior.

Laboratory analysis of soil specimens provided water content, total weight, and dry weights. Also values for internal angle of friction (phi) and cohesion (C) were established for each sample by utilizing maximum and minimum values from laboratory analysis (Cooper Testing Lab, unpub. data, 1998) and blow counts. Samples were taken from the base of scarps in the upper and lower section after a long dry period. Field investigation revealed that soil in the middle section was similar to the lower section, therefore the values for the lower section were used to represent the middle section.

Piezometric surface, pore pressure ratio, and pore pressure were adjusted in each section to match the ground water table conditions observed in the field. Phi and C for the dry scenario were taken from the direct shear results. Phi and C for the wet and saturated scenarios were estimated based on representative values for clayey sand under 
similar conditions (Romie, 1990). Once the piezometric surfaces for each section, under each condition, were established, they were entered into a simple computer program and infinite slope spreadsheets. 


\section{CONCLUSIONS}

The geologic contact at Cleveland Corral causes the middle section slide to be oriented north-south, rather than SSW, which is directly down slope. The geologic contact between $\mathrm{Kgr}$ and $\mathrm{pKm}$ is a zone of weakness in the bedrock and a conduit for groundwater which accumulates and maintains higher piezometric surfaces and pore pressures relative to the rest of the slide. This causes the slide to be aligned in a more southerly direction along its eastern margin.

The Cleveland Corral landslide is a complex translational debris slide-debris flow that was set in motion by above average rainfall of sufficient duration and intensity. The slide can be divided into three distinct sections: upper. middle, and lower. The upper section is an active nested debris slide, which is accumulating material above the currently stable toe area. Hydrologically, this section receives the least groundwater from seepage, due to its relative position on the slope, and has natural drainage properties which enhance the stability of the upper section toe.

The middle section is in tension from top to bottom. Its entire surface is characterized by tension cracks and minor scarps. Once pore pressures rose to sufficient levels and the FOS became less than 1.0, sliding commenced and this section moved as a single block. Its rate of sliding responded directly to increased pore pressure when daily rainfall totals were greater than $2.5 \mathrm{~cm}$. Sliding was sustained after the rains ceased, due to groundwater seepage. Mass wasting, which is eroding the north western portion of the middle section, may behead the middle section and capture the upper section unless, the upper section fails earlier. 
The lower section is a fully developed debris slide-debris flow. This section mobilized sometime during the spring of 1996 , initiating at a break in the bedrock slope, which separates the lower and middle sections. This debris slide moved toward Highway 50 , and upon meeting resistance from large trees, developed a toe bulge and stopped. The lower section was the most active section at Cleveland Corral due to sustained high pore pressure as a result of ground water seepage. Three factors prevented the lower section from effectively reducing pore pressures. First the deformation involved during the formation of a toe bulge destroyed the colluvium's drainage system and reduced the lower section's ability to drain. Secondly, the lower section's position near the base of the entire slope ensured the receipt of plentiful groundwater seepage during and long after precipitation. Finally, rains during the $1997-98$ winter were 175 percent of average in January, 225 percent of average in February, and 125 percent of average in March and April. As a result of increased pore pressures, the toe resumed sliding and moved approximately $5.6 \mathrm{~m}$ (18.5 ft) (M. Reid, USGS, written commun., 1998). When saturated, the material along the leading edge of the toe bulge flowed.

Results from simplified models used for infinite slope calculations and limit equilibrium computer analysis were in general agreement with field observations. However, calculations could not be used to predict the initiation of slope failure in any particular section. 


\section{LIMITATIONS}

As an input to the computer model, the geologic cross section is only well constrained at the upper section where six boreholes were drilled and a seismic survey was conducted. Even so, the variability of depth and colluvium recorded at closely spaced borings and the possibility of more than one fit for the seismic profile, demonstrate the complexity of heterogeneous colluvium found at sites of recurring landslides such as Cleveland Corral. The preliminary results of the USGS seismic survey were used to develop the lower middle section and upper lower section, geologic profile. The remainder of the lower section profile can be reasonably interpreted from field observation. Because of the uncertainties noted above, the models do not reflect detailed variations in bedrock profile and colluvium thickness within each particular section.

All data obtained from the World Wide Web, i.e., the USGS Cleveland Corral landslide web site, are considered provisional data. Because of the harsh operating conditions at the site, occasional erroneous output occurred. Therefore all conclusions or inferences based on monitoring data are the responsibility of the author.

All USGS seismic survey results shall be considered preliminary and provisional. The author who assisted in the field portion of this survey, has used the preliminary results to formulate valid assumptions regarding the nature of the subsurface profile at Cleveland Corral. 


\section{REFERENCES CITED}

Anderson, S.A., and Sitar, N., 1995, Analysis of rainfall inducing debris flows: Journal of Geotechnical Engineering. v. 121, no. 7, p. 544-551.

Boyd, A., 1996, Notification letter and geologic map of landslide scarps in Whitehall and Riverton area: U.S. Forest Service, Eldorado National Forest, Placerville District Ranger Station, letter dated May 20, 1996.

Campbell, R.H., 1975, Soil slips, debris flows, and rainstorms in the Santa Monica Mountains and vicinity, Southern California: U.S. Geological Survey Professional Paper 851, $51 \mathrm{p}$.

Cruden, D.M., and Varnes, D.J., 1996, Landslide types and processes, in Turner, A.K., and Schuster, R.L., eds., Landslides- investigation and mitigation: National Research Council, Transportation Research Board, Special Report 247, p. 36-75.

Dietrich, W.E., Wilson, C.J., and Reneau, S.L., 1986, Hollows, colluvium, and landslides in soil mantled landscapes, in Abrahams, A., ed., Hillslope processes: $16^{\text {th }}$ Annual Geomorphology Symposium, Binghampton, New York: Allen and Unwin Ltd., Winchester, Massachusetts., p. 361-388.

Duncan, J.M., Buchignani, A.L., and De Wet, M., 1987, An engineering manual for slope stability studies: Virginia Polytechnic Institute and State University, Blacksburg, $80 \mathrm{p}$.

Ellen, S.D., and Fleming, R.W., 1987, Mobilization of debris flows and soil slips, San Francisco Bay region, California, in Costa, J.E., and Wieczorek, G.F., eds., Debris flow/avalanches- process, recognition, and mitigation: Reviews in Engineering Geology, v. 7, Geological Society of America, Boulder, Colorado, p. 31-40. 
Howard, T. R., Baldwin II, J.E., and Donley, H.F., 1988, Landslide in Pacifica, California, caused by the storm, in Ellen, S.D., and Wieczorek, G.F., eds., Landslides, floods and marine effects of the storm of January 3-5, 1982, in the San Francisco Bay region, California: U.S. Geological Survey Professional Paper 1434, p. 163-184.

Johnson, K.A., and Sitar, N., 1990, Hydrologic conditions leading to debris flow initiation: Canadian Geotechnical Journal, v. 27, p. 789-801.

Jones, D.L., Graymer, R., Lawler, D., and Wagner, D., 1997, Northern Sierra Nevada region geological field trip guidebook. October 11 and 12, 1997: Northern California Geological Society, variously paged.

Kesseli, J.E., 1943, Disintegrating soil slips of the Coast Ranges of Central California: Journal of Geology, v. 51, no. 5, p. 342-352.

Keuhn, M.H., and Bedrossian, T.L., 1987, 1983 U.S. Highway 50 landslide near Whitehall, El Dorado County, California: California Geology, v. 40, no. 11, p. 247-255.

Lambe, T.W., and Whitman, R.V., 1969, Soil Mechanics: Massachusetts Institute of Technology, Wiley, New York, $553 \mathrm{p}$.

McCarthy. P.E., 1993. Essentials of soil mechanics and foundations: Basic Geotechnics: $4^{\text {th }}$ ed., Prentice Hall. New Jersey, p. 95.

Romie, J.E., 1990. A computer assisted engineering geologic investigation of the Blucher Valley Landslide, Sebastopol, California: [M.S. Thesis], San Jose State University, San Jose California, 98 p.

Sidle, R.C., Pearce, A.J., and O'Laughlin, C.L., 1985, Hillslope stability and land use: Water Resources Monograph 11, American Geophysical Union, Washington, D.C., 140 p. 
Skempton, A.W., and Hutchinson, J.N., 1969, Stability of natural slopes and embankments foundations, in Proc., seventh international conference on soil mechanics and foundation engineering: Sociedad Mecicana de Mecana de Suelos, Mexico City, State of the Art Volume, p. 291-340.

Sydnor, R.H., 1997, Reconnaissance engineering geology of the Millcreek Landslide of January 24, 1997, U.S. Highway 50, El Dorado County, California: California Department of Conservation, Division of Mines and Geology, $10 \mathrm{p}$.

U.S. Forest Service, 1996, El Dorado National Forest Map: USDA Forest Service, Geometronics Service Center, Salt Lake City, Utah, from Forest Service Primary Base Series and USGS quadrangle maps, scale 1:126,720, 1 sheet.

Van Aller, H.W., 1994, STABL Editor (STED): v6.32c, Interface for slope stability software analysis package (PCSTABL) version 5M, by Purdue University.

Wagner, D.L., and Spittler, T.E., 1997, Landsliding along the Highway 50 Corridor, geology and slope stability of the American River Canyon between Riverton and Strawberry, California: California Department of Conservation, Division of Mines and Geology, Open-File Report 979-22, 25 p.

Oblique Color Aerial Photos: Caltrans, 3-21-97, $3 \# 3-97-08121,03 / 09 / 15 / 17$ 
APPENDIX A

COMPUTER MODEL OUTPUT 
Appendix A lists the plot files of the computer models for the Cleveland Corral Landslide. Plot files were printed for upper, middle, and lower sections during wet and saturated conditions, using the sliding block and specified surface calculation methods. During wet conditions the piezometric surface in the upper, middle, and lower sections was determined to be $0.5,0.67$, and 0.75 of the true colluvium thickness respectively. During saturated conditions the ground water table was at the ground surface for all sections.

The sliding block method required two rectangular blocks positioned along the failure plane to account for its irregular surface. The results list the ten most critical failure planes in descending order of FOS value. The failure planes are plotted on the landslide section with the number one failure plane (lowest FOS) plotted as a bold line with arrows pointing to the position where the failure plane intersects the ground surface. The specified surface method calculates the FOS for a failure plane designated by the user. For this study the specified surface was determined to the colluvium/bedrock contact for each of the three sections.

The following is an annotated plot file header provided to identify the computer method, section, and ground water condition used to calculate the FOS:

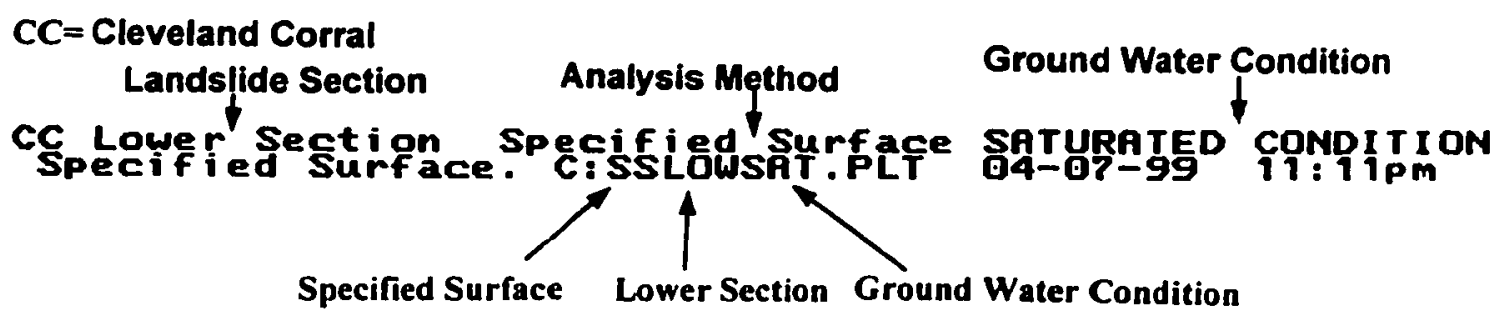

The following pages are PCSTBL plot files for the sliding block and specified surface methods. They have been annotated to explain the plot file symbology. 


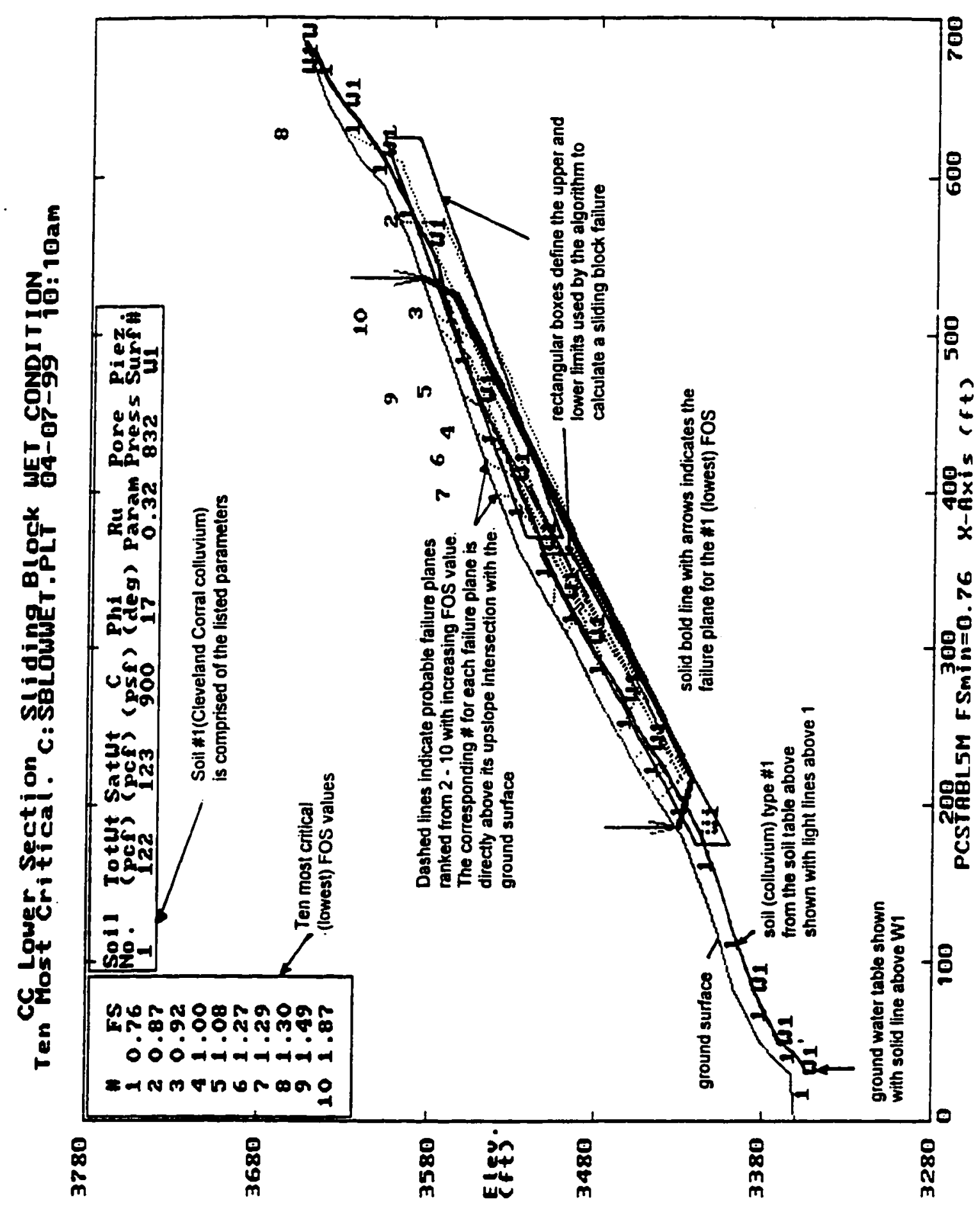




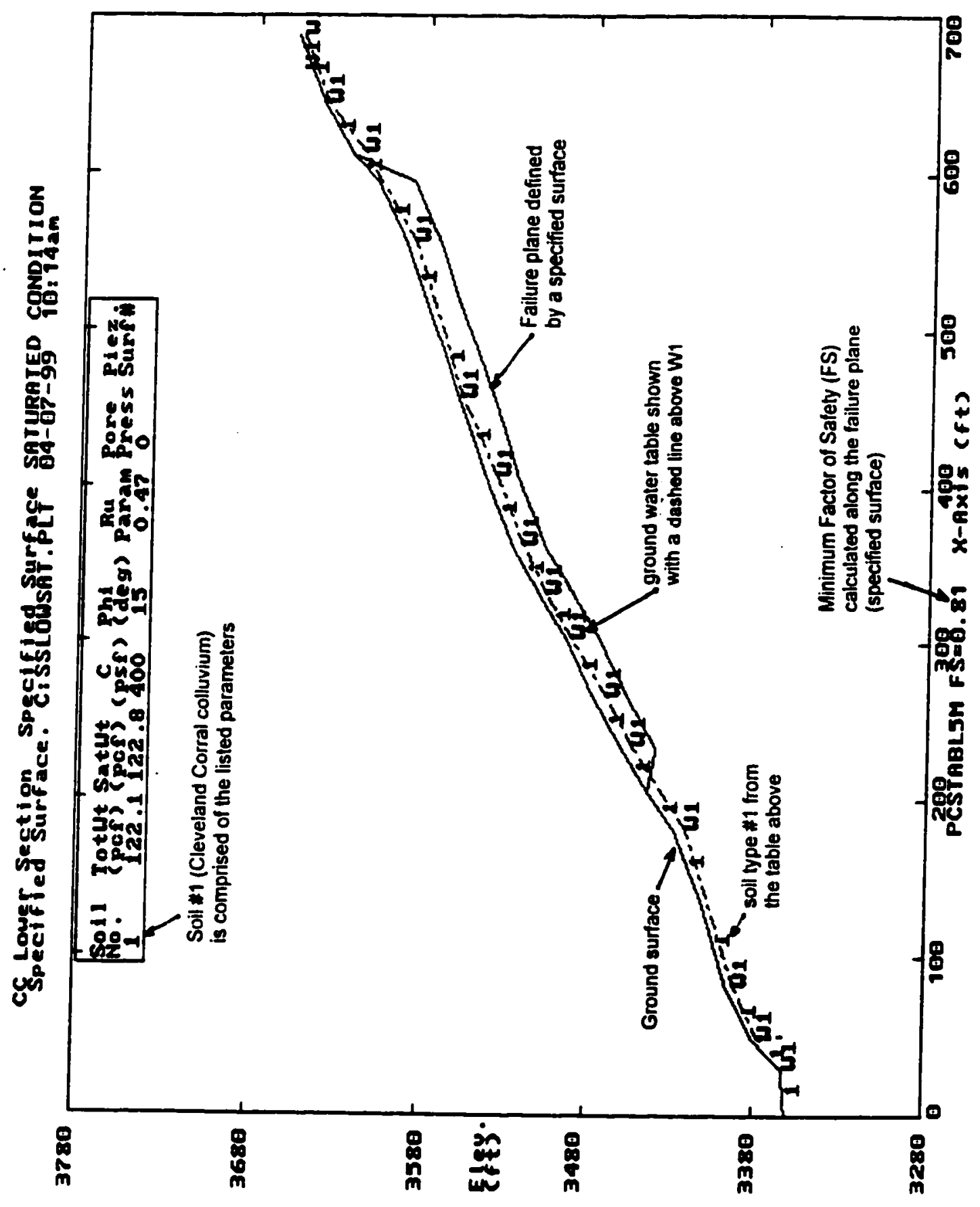




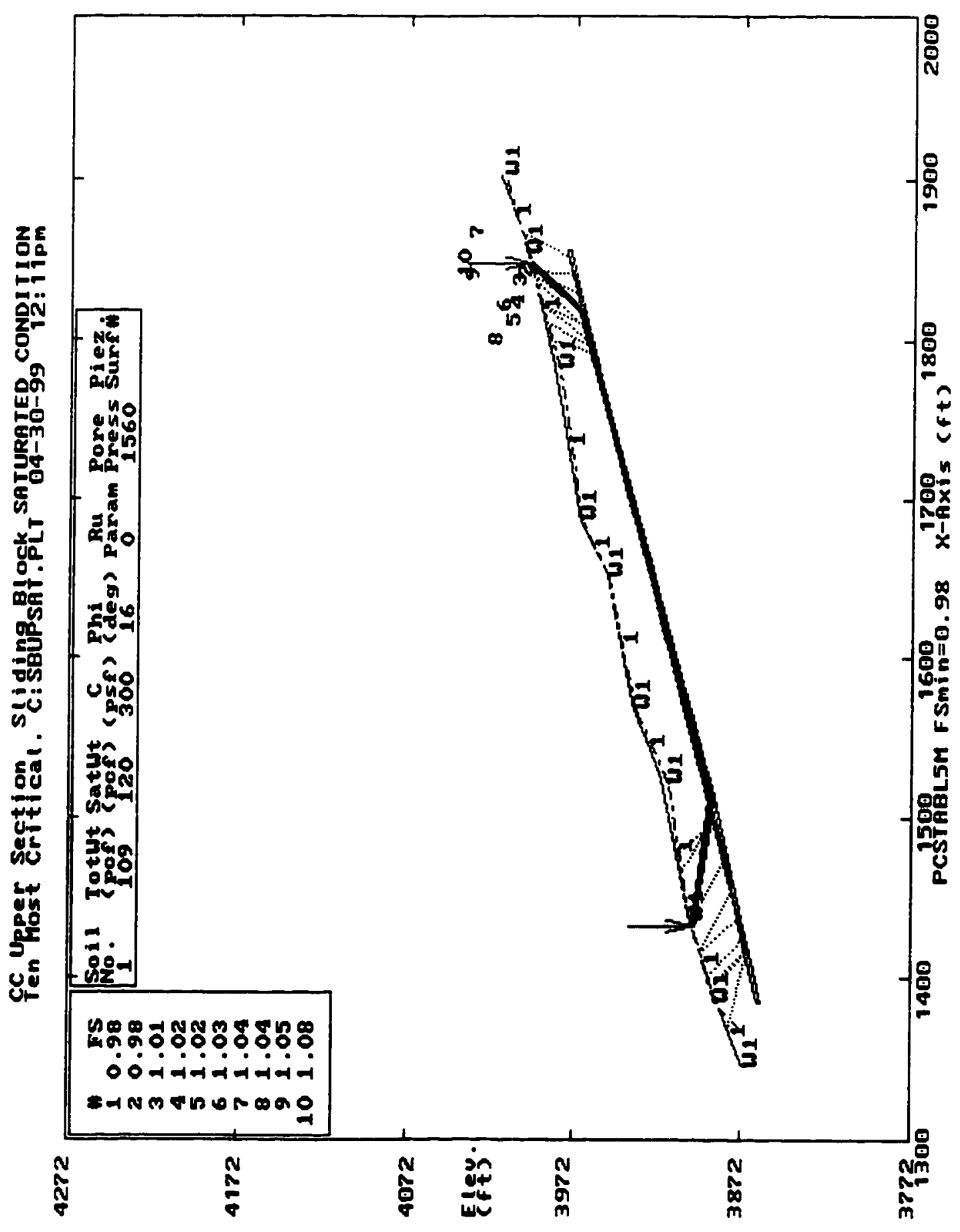




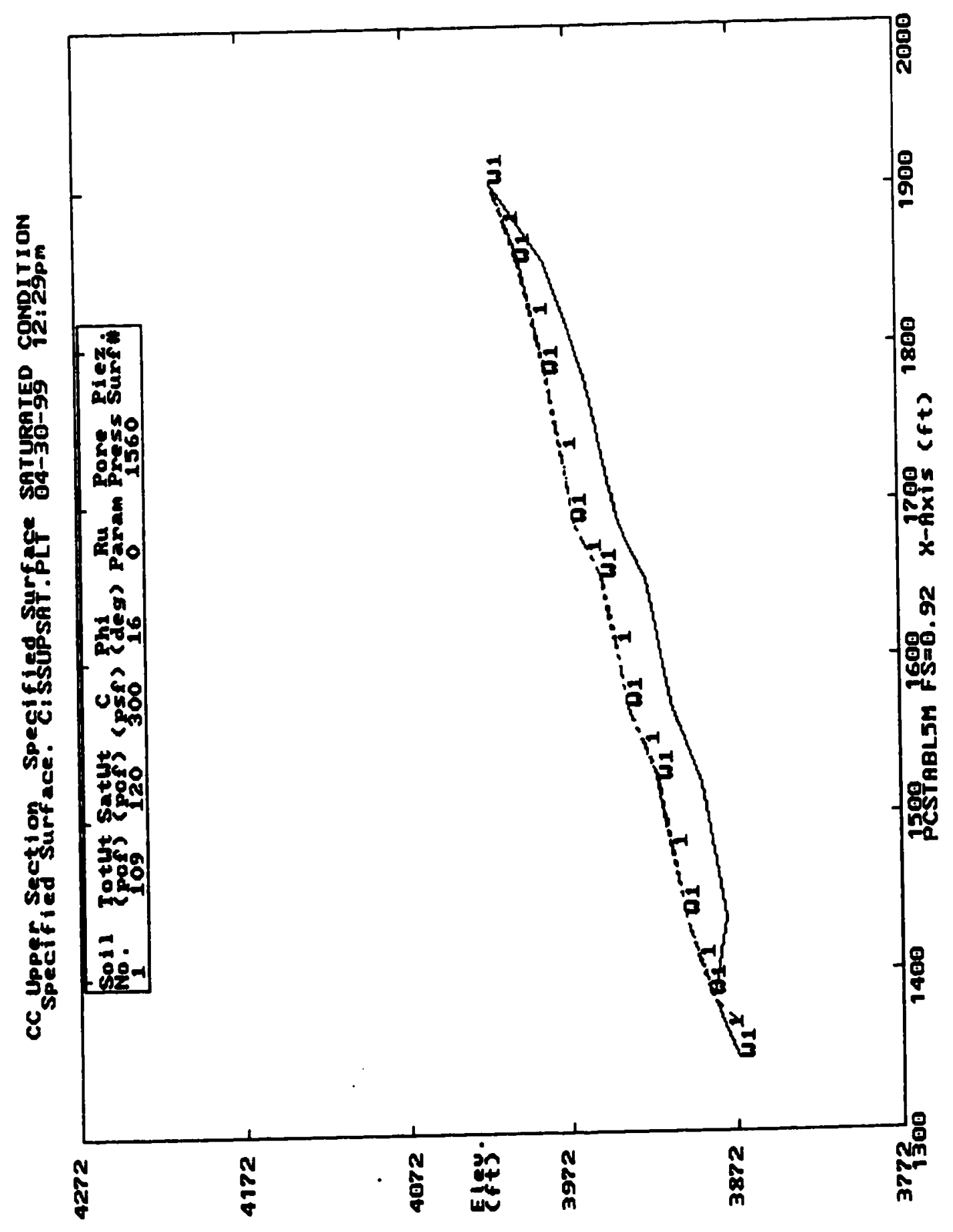




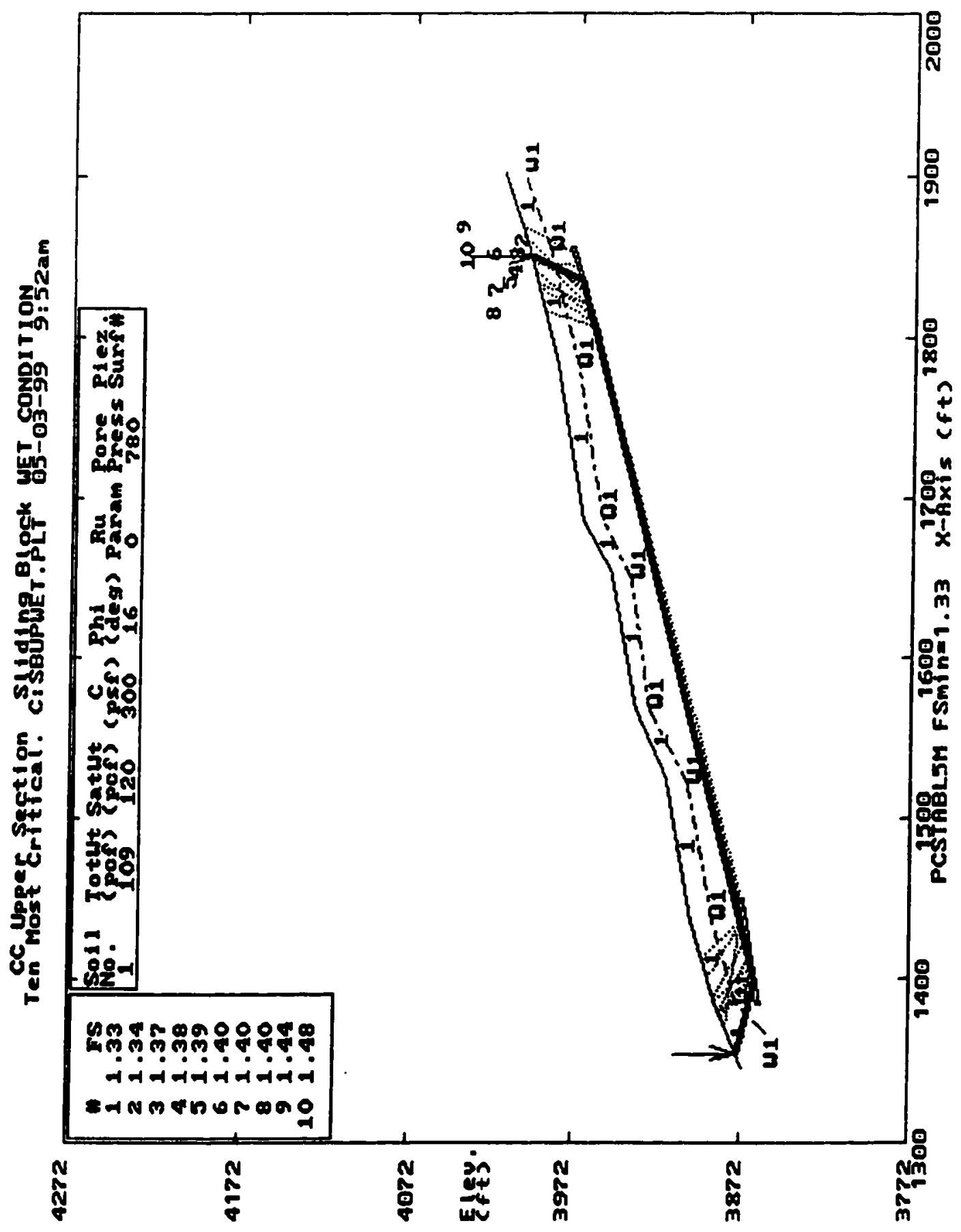




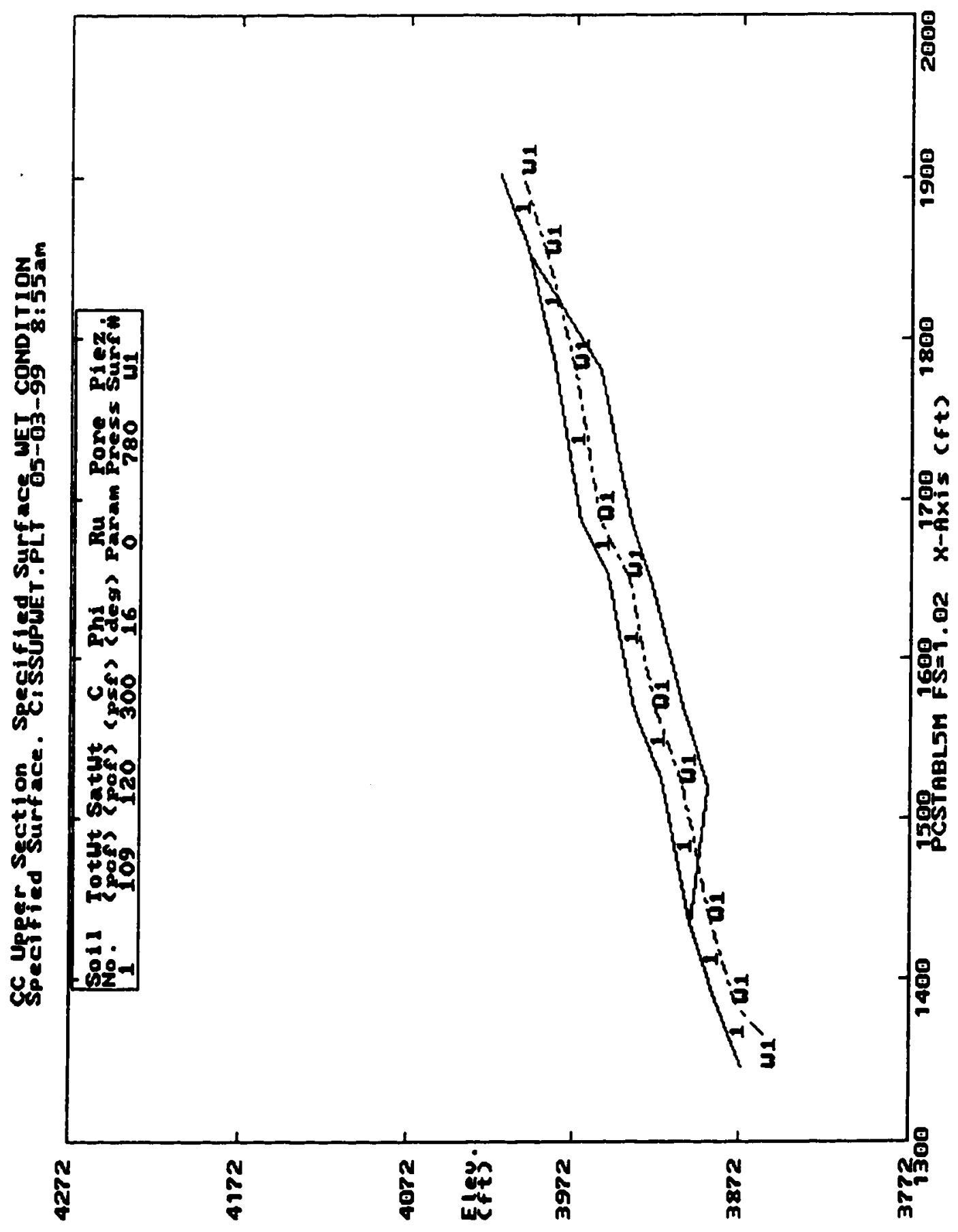




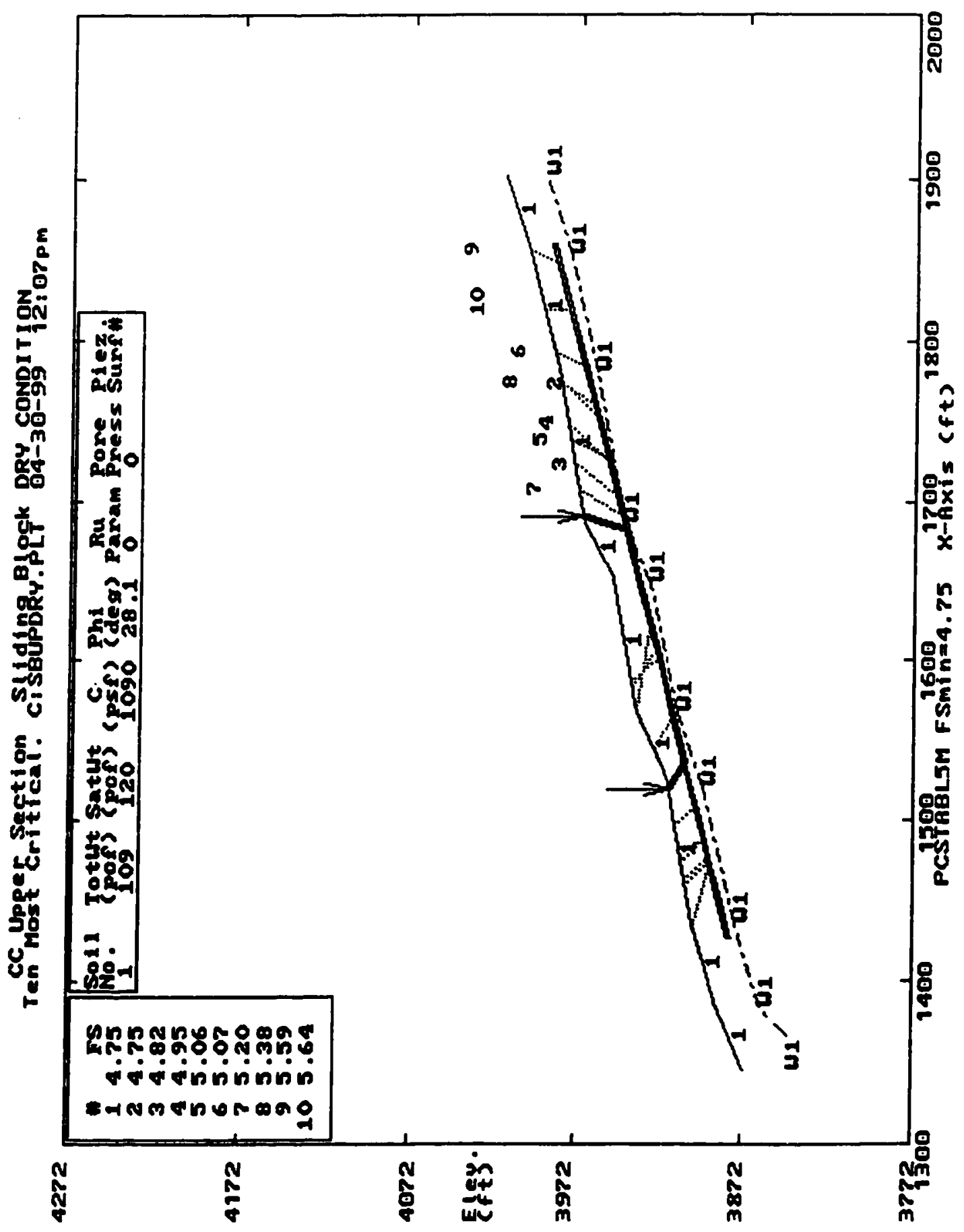




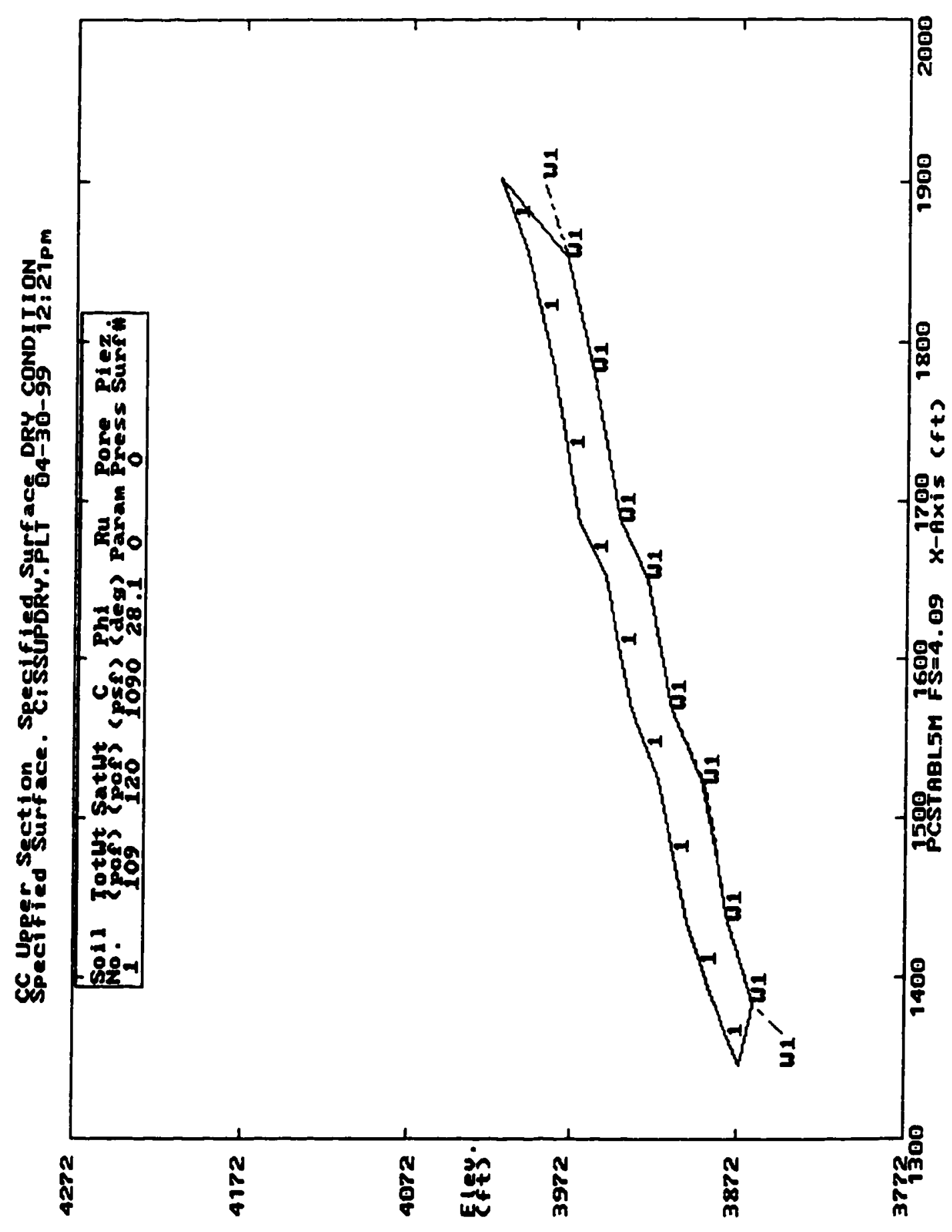




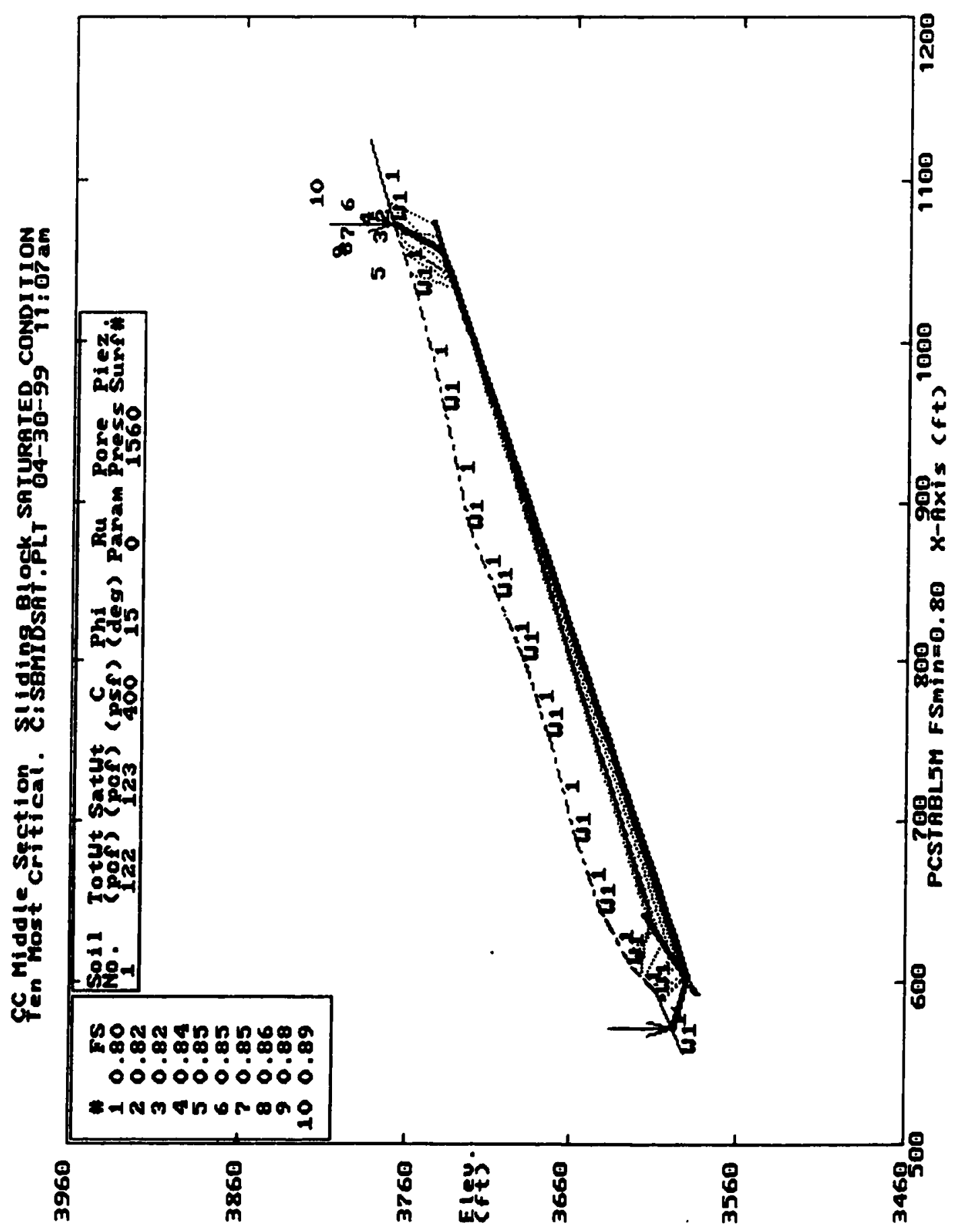




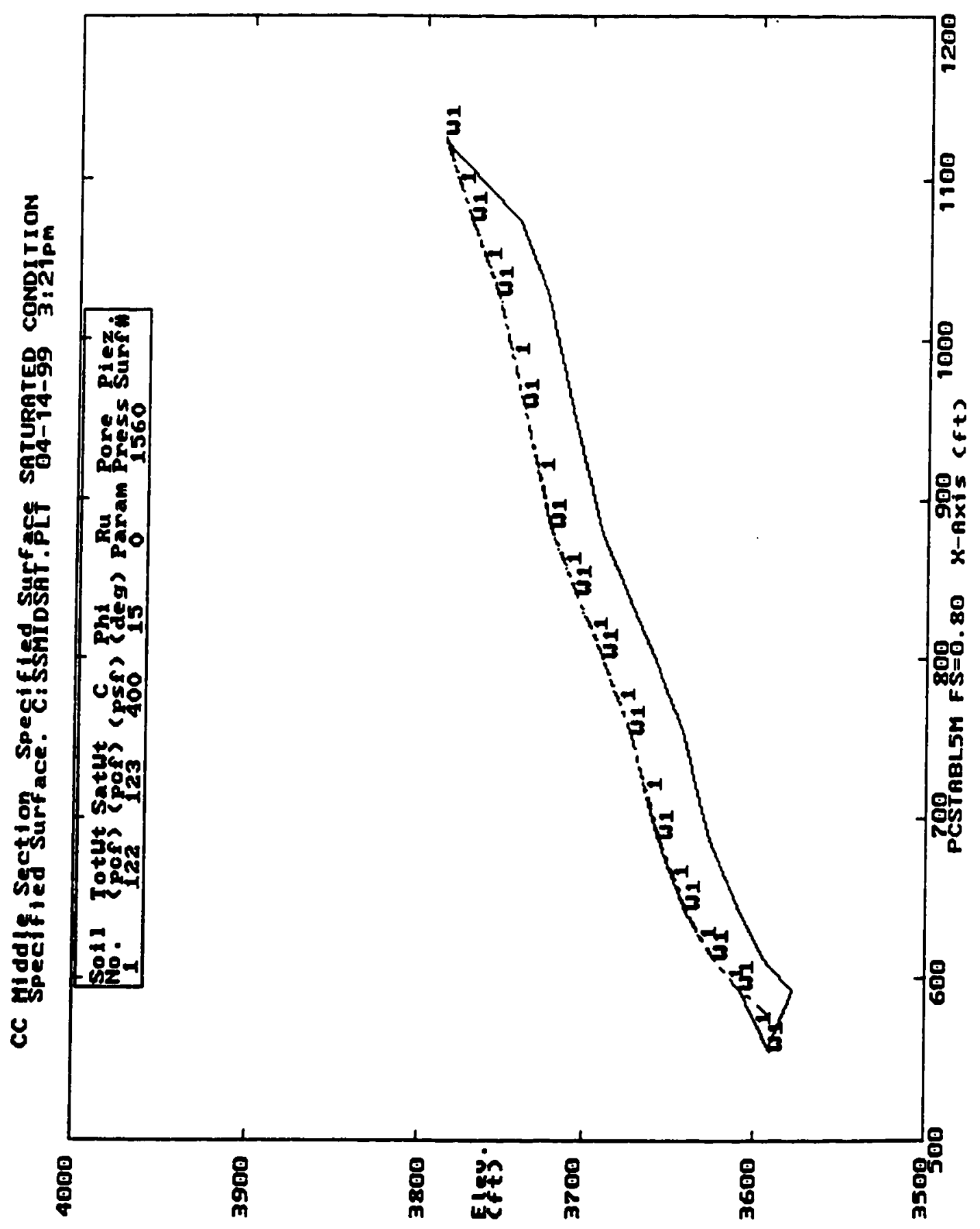




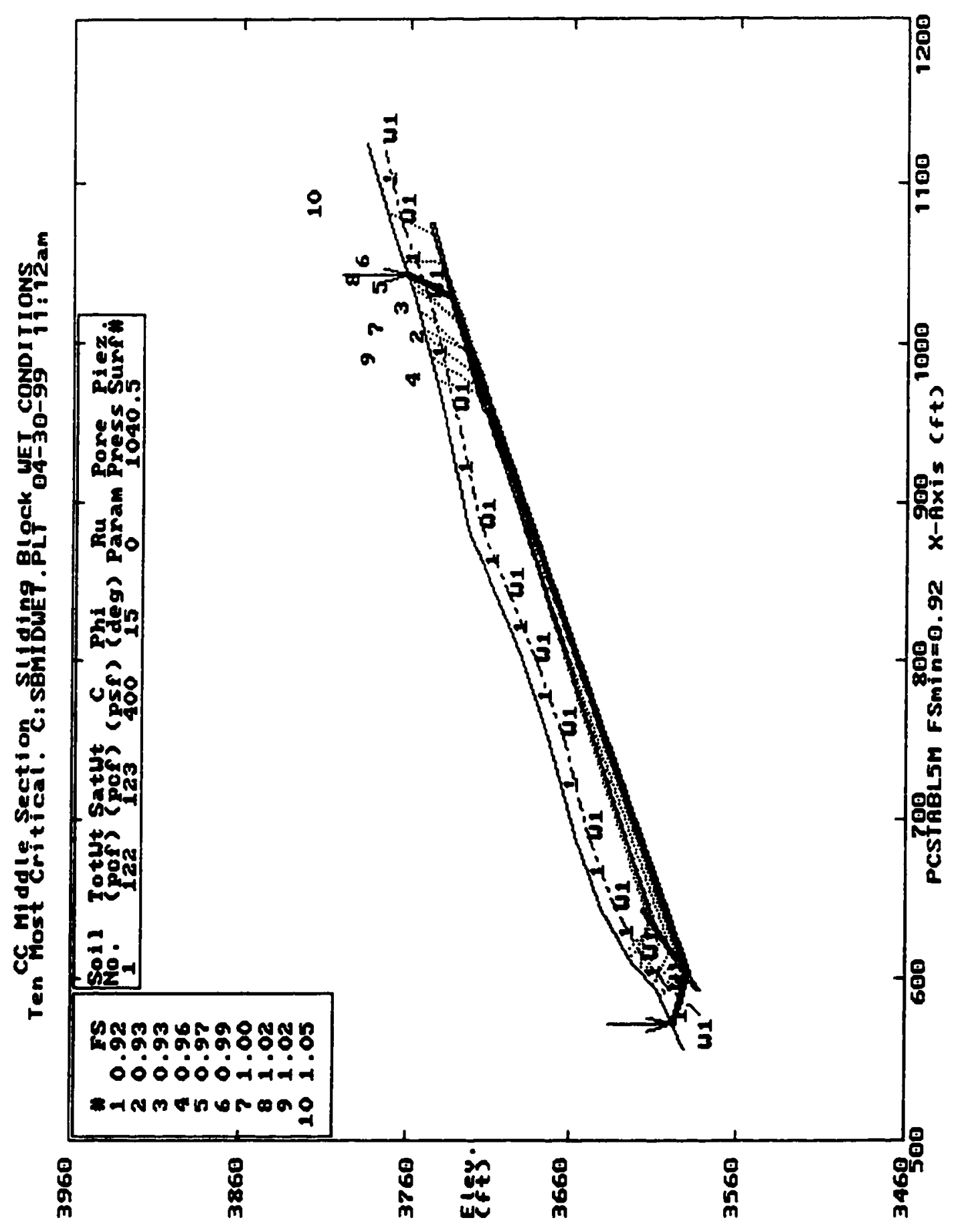




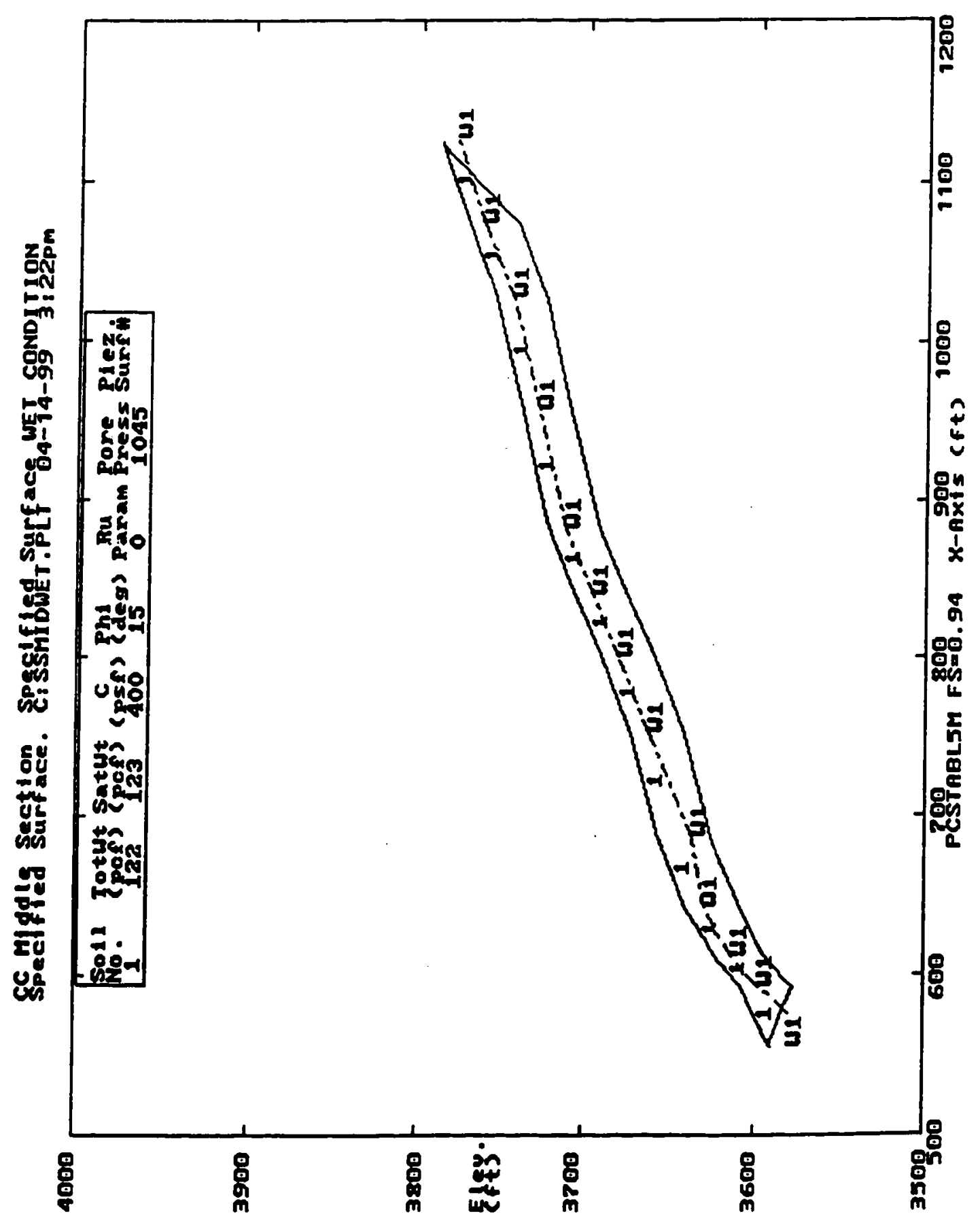




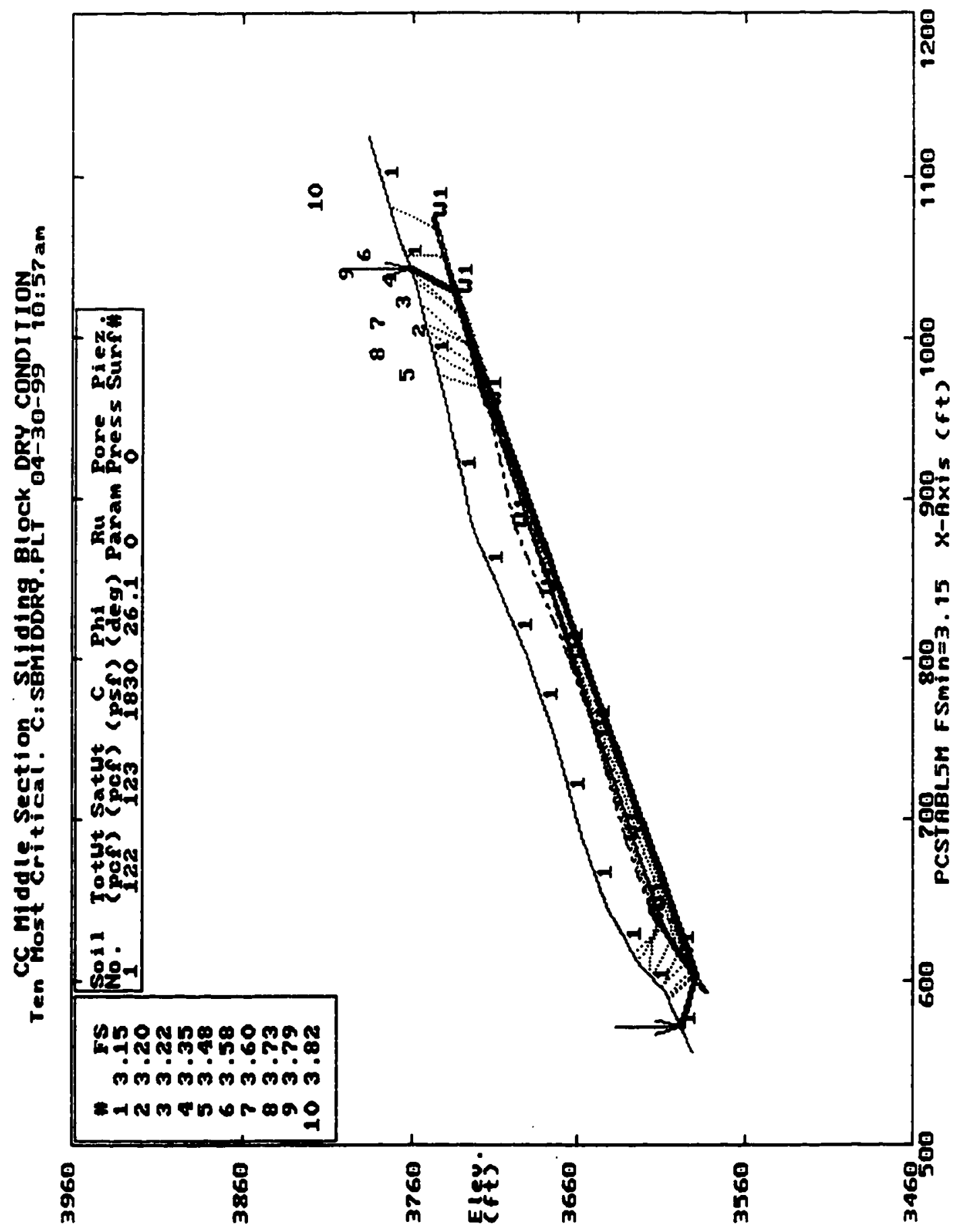




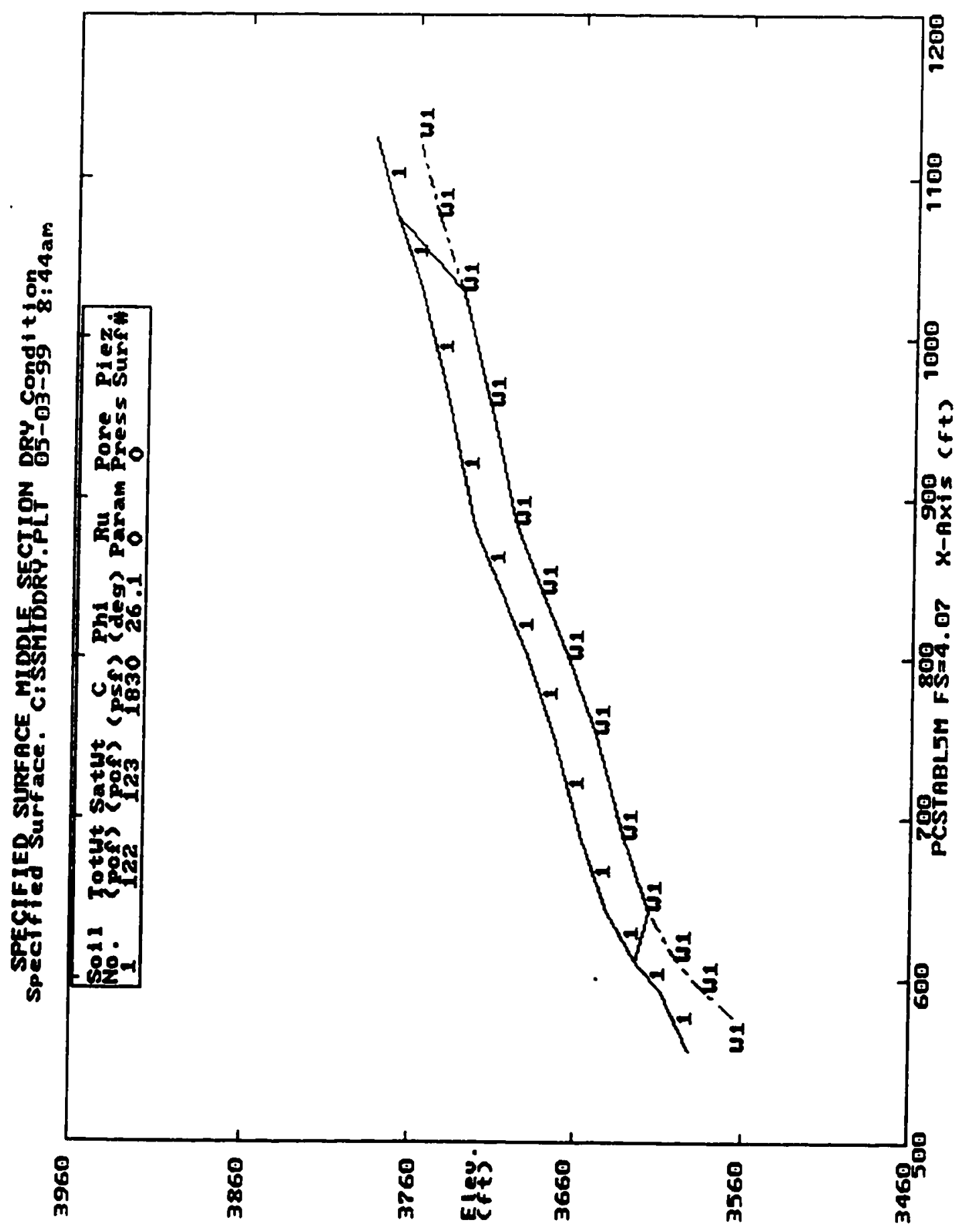




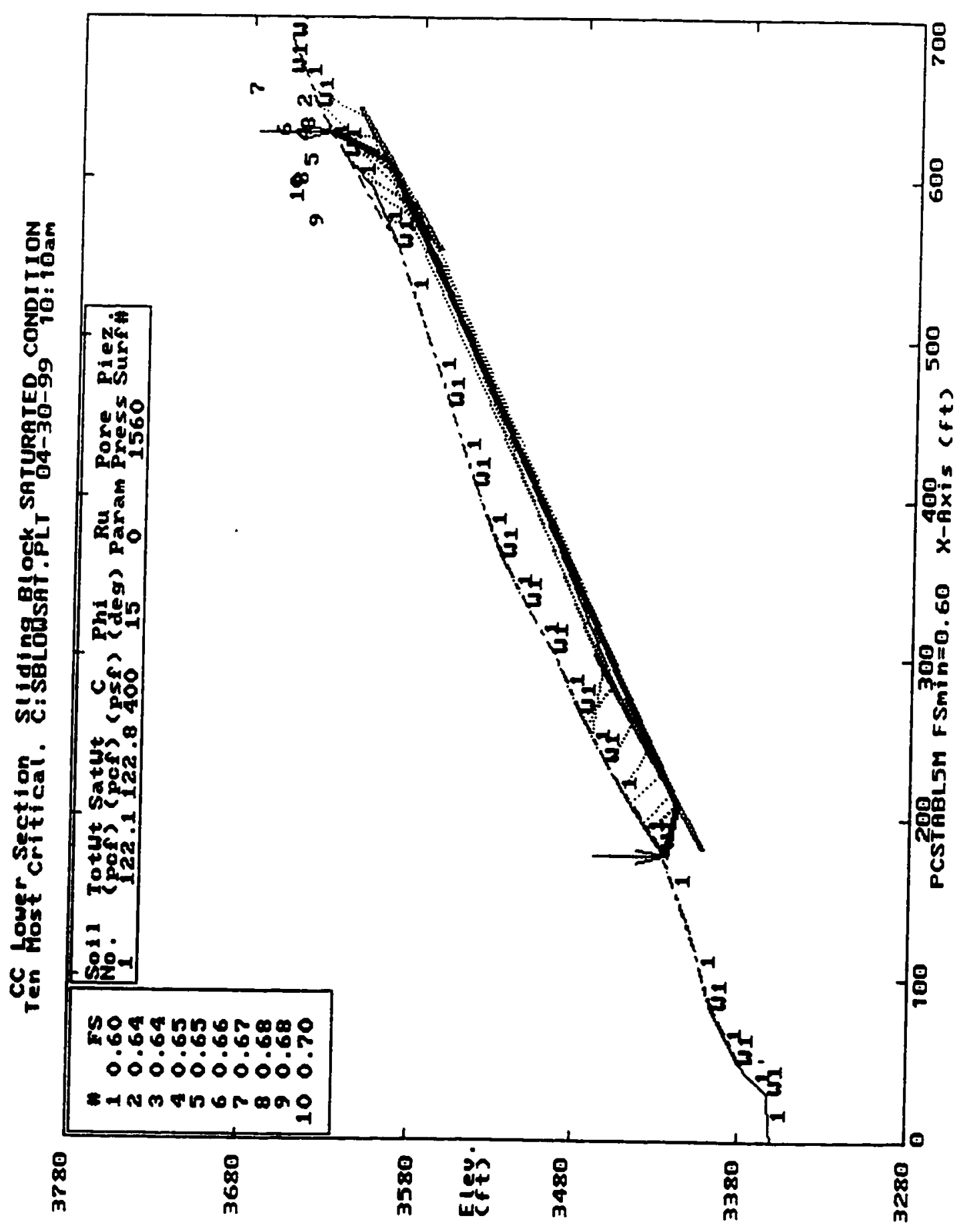




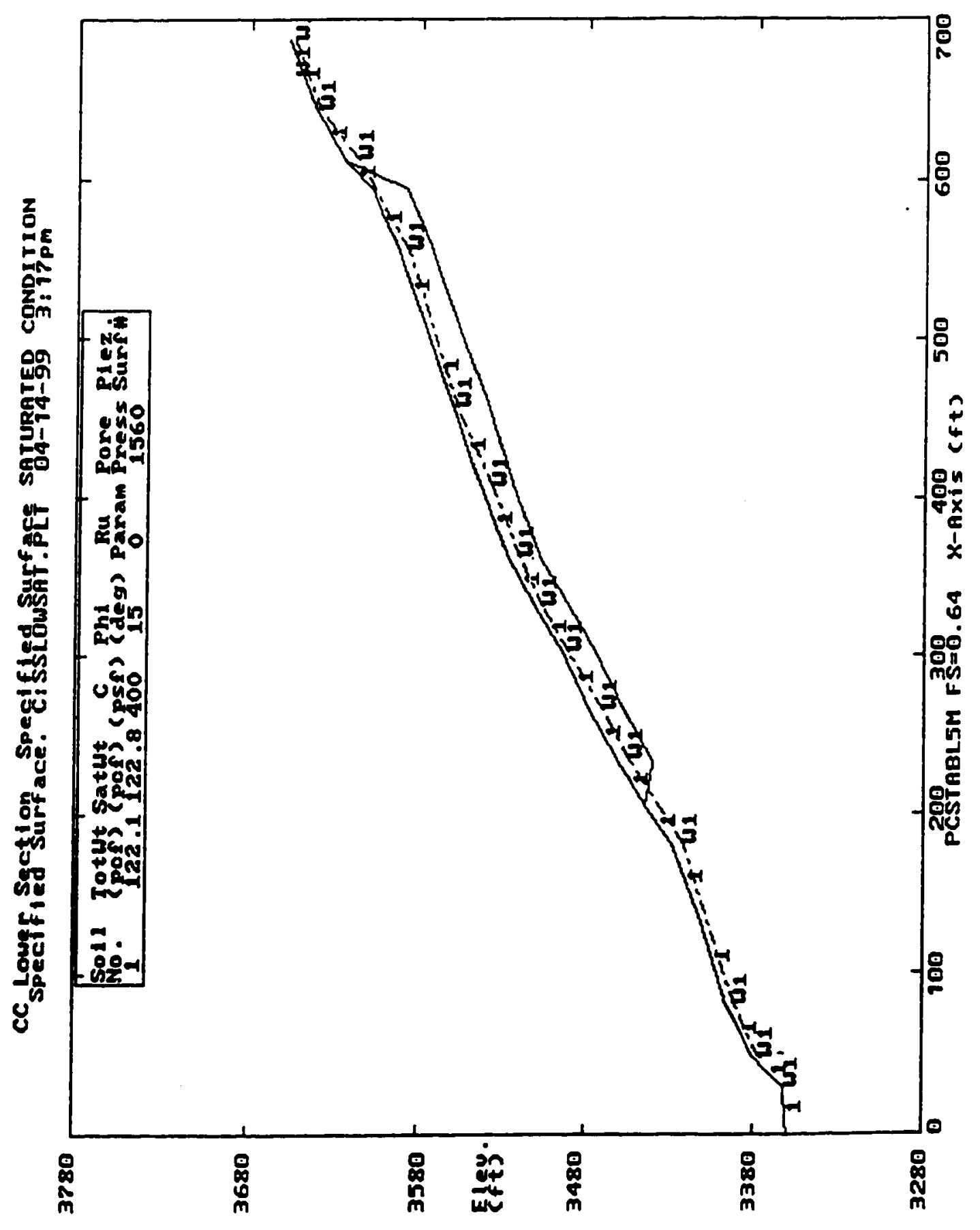




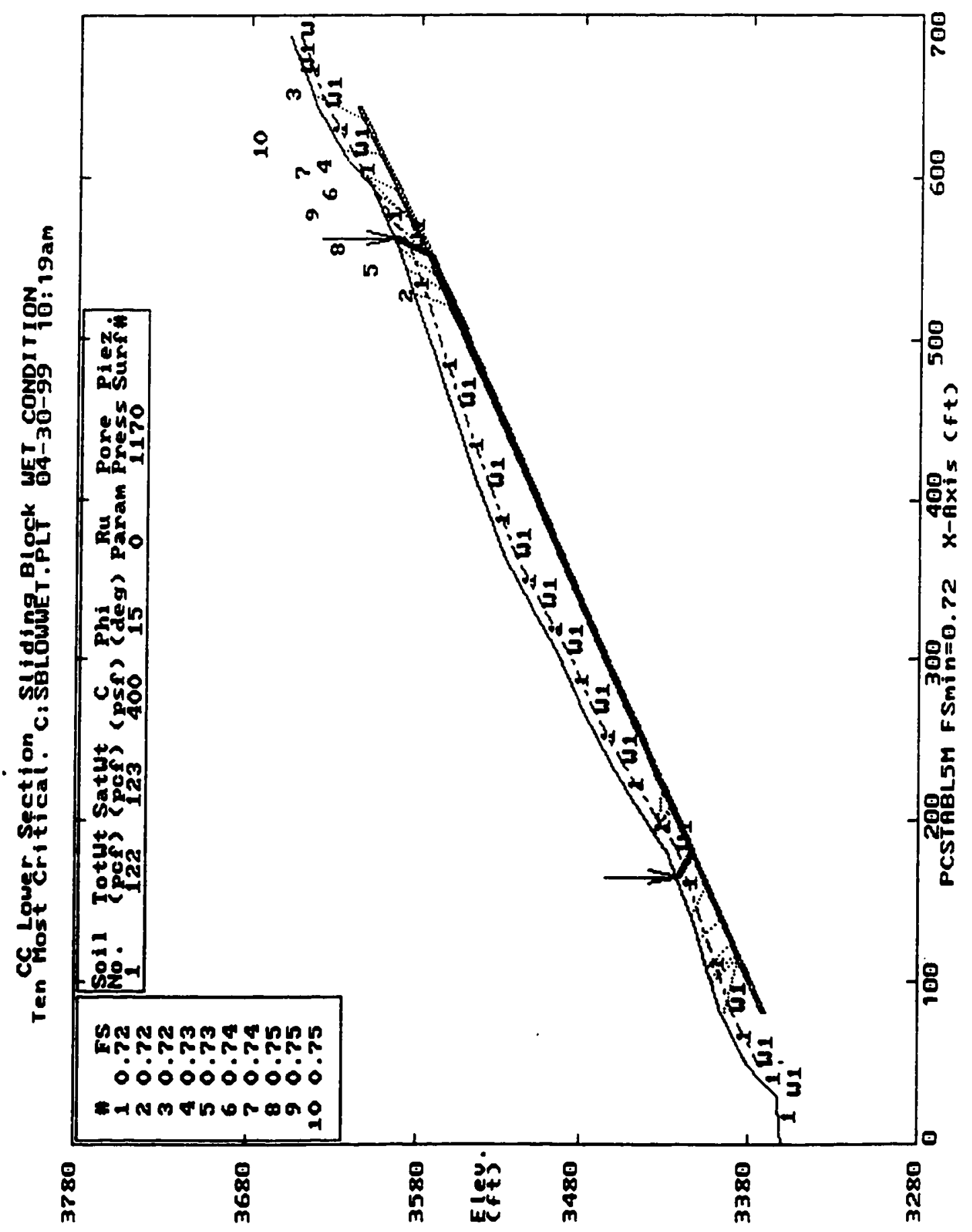




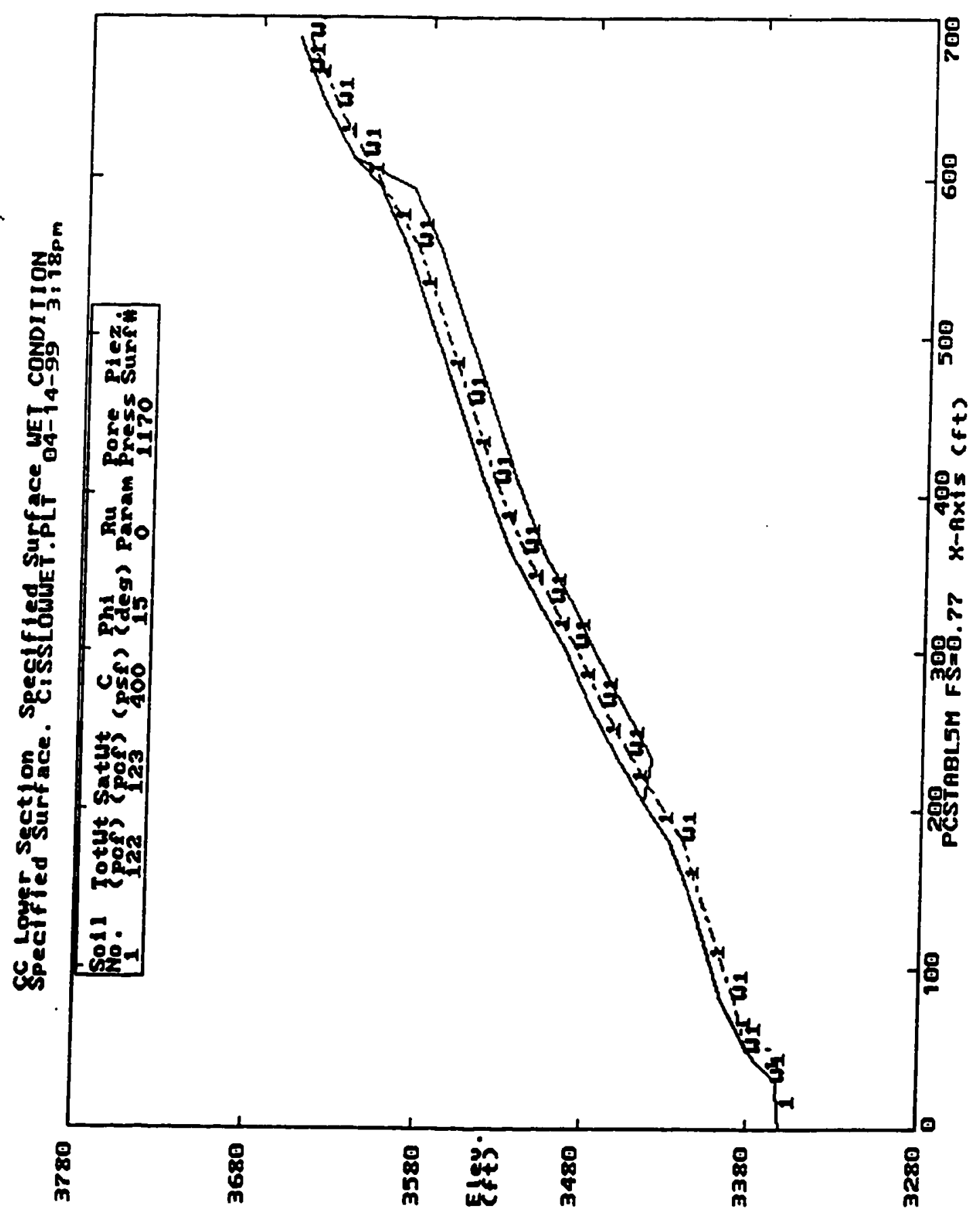




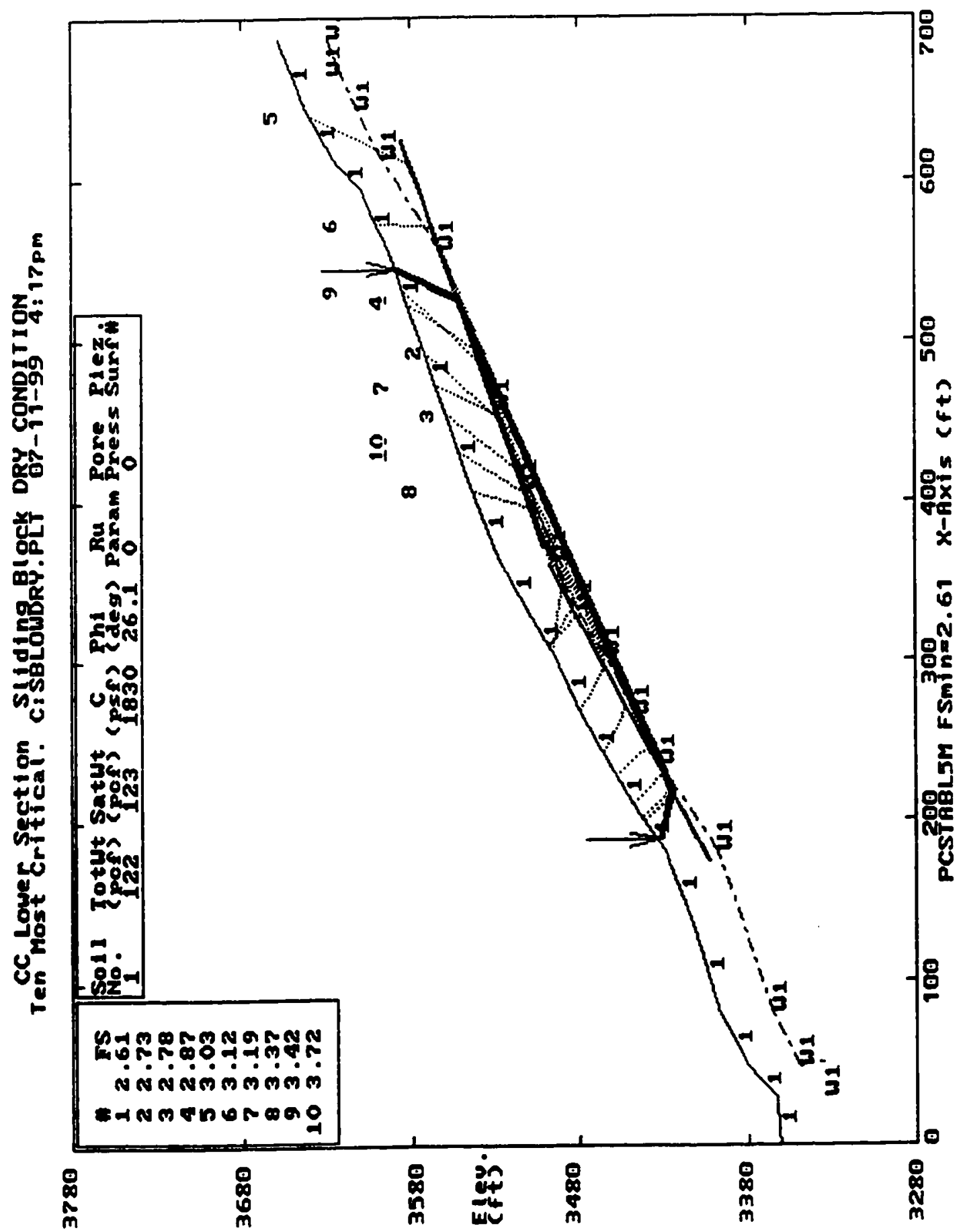




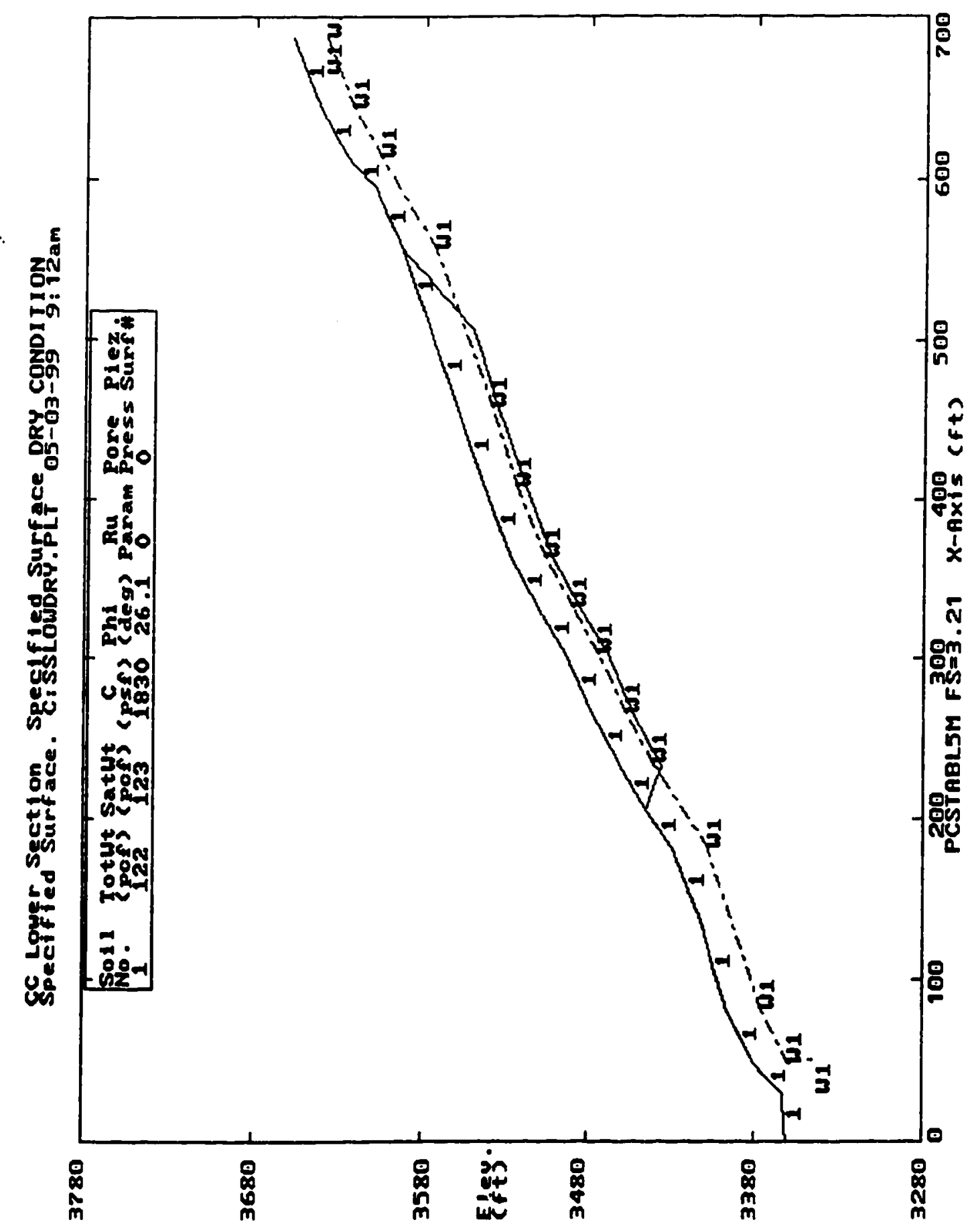


APPENDIX B

INFINITE SLOPE MODEL OUTPUT 
Infinite Slope calculations including parallel and emerging seepage. Factor of Safety values are calculated along the bedrock/colluvium failure plane for each section under wet and saturated ground water table conditions. Below is an explanation of the calculations utilized in the Factor of Safety spreadsheets.

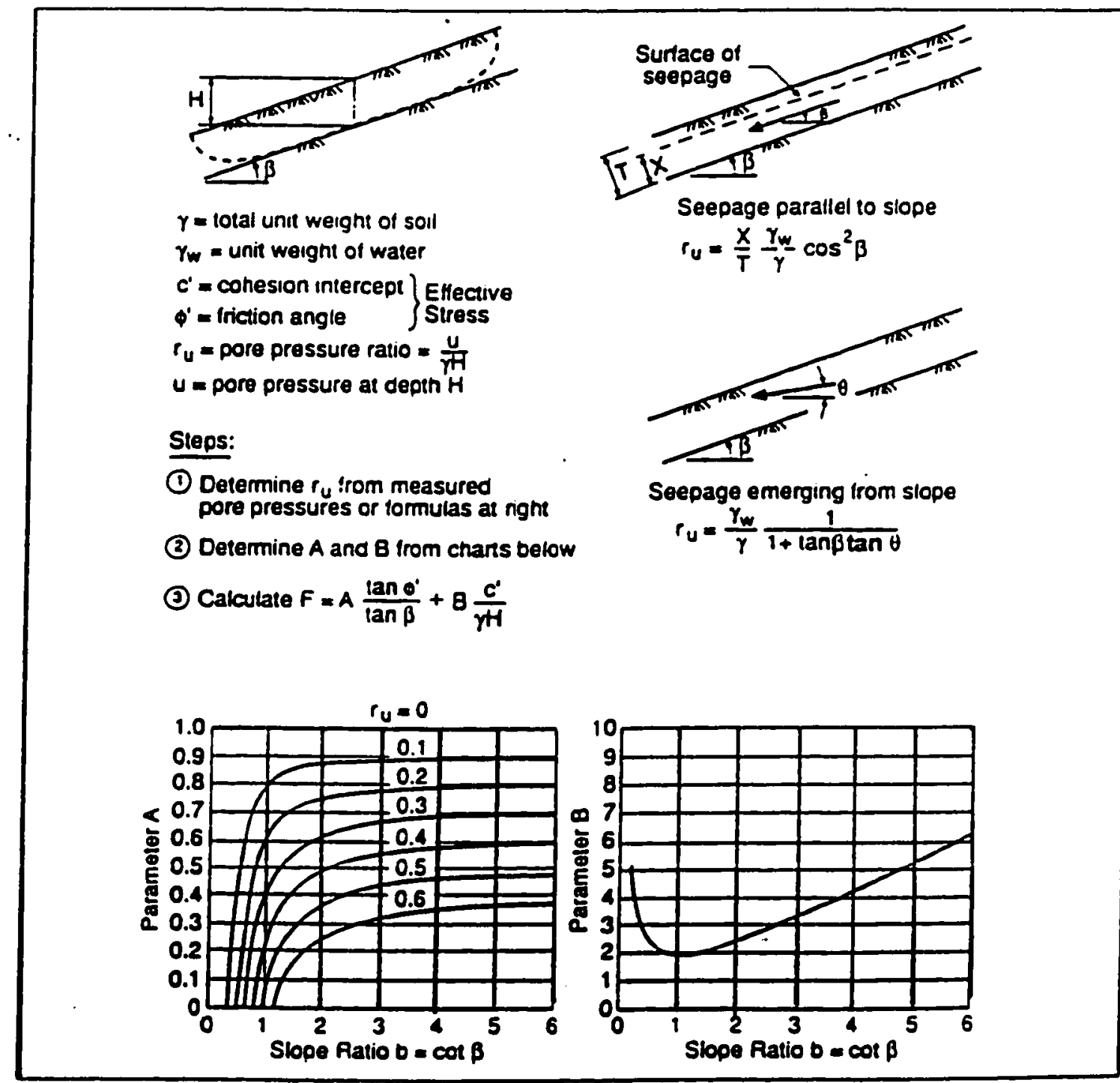

Stability charts for

infinite slopes

(modified from

Duncan et al. 1987) 
Factor of Safety by Infinite Slope using

Parallel / Emerging

Seepage

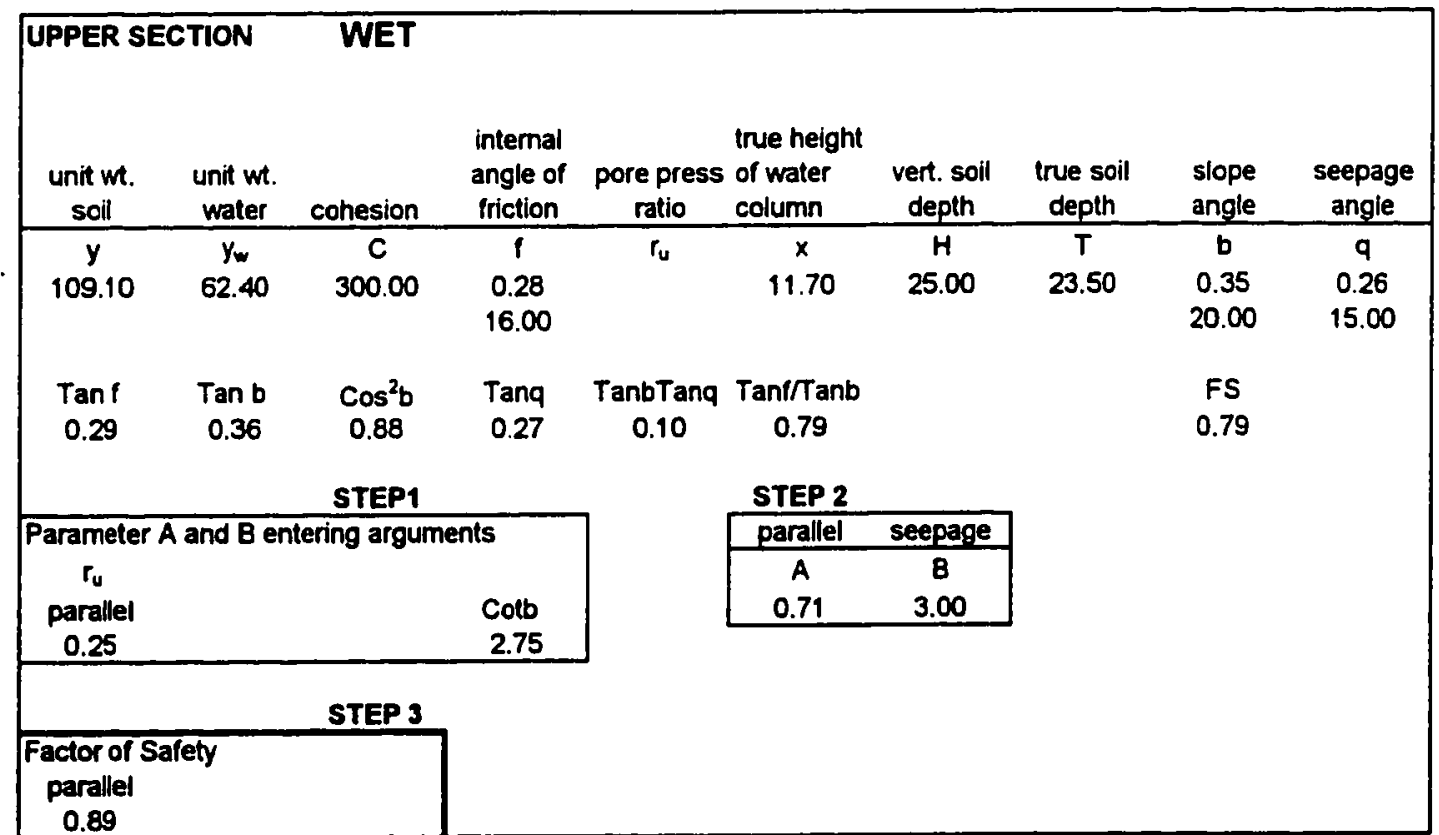

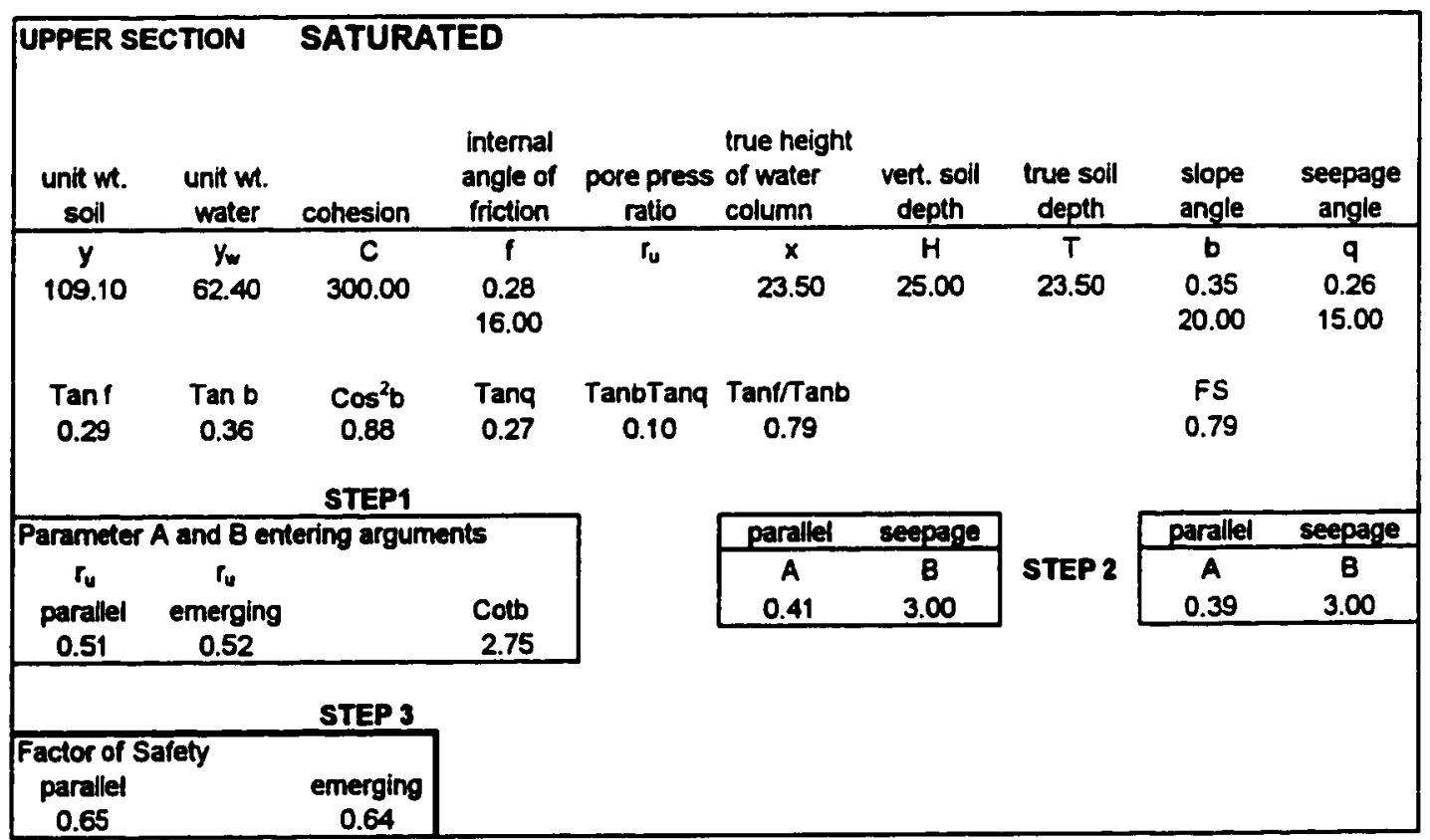


Factor of Safety by Infinite Slope using

Parallel / Emerging

Seepage

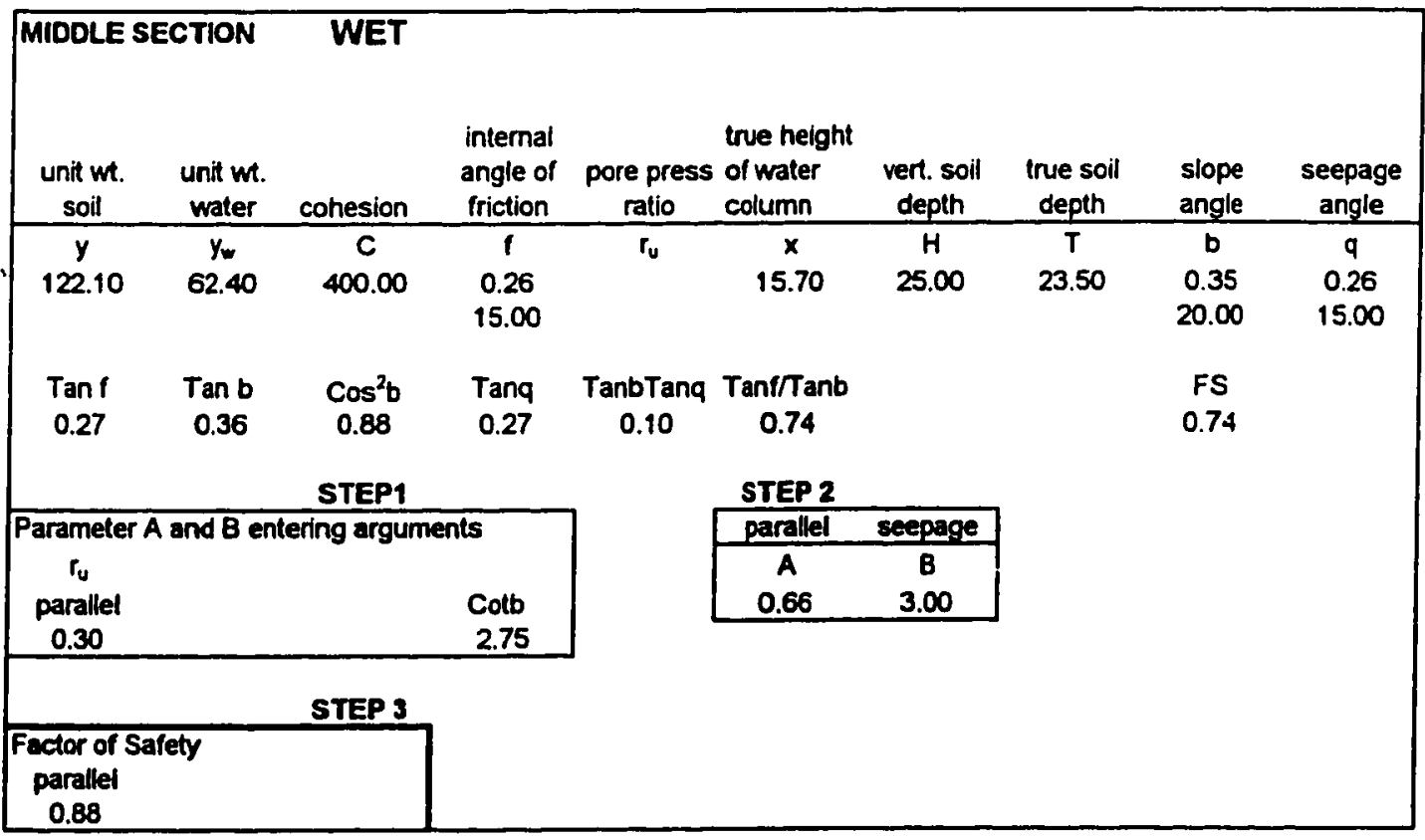

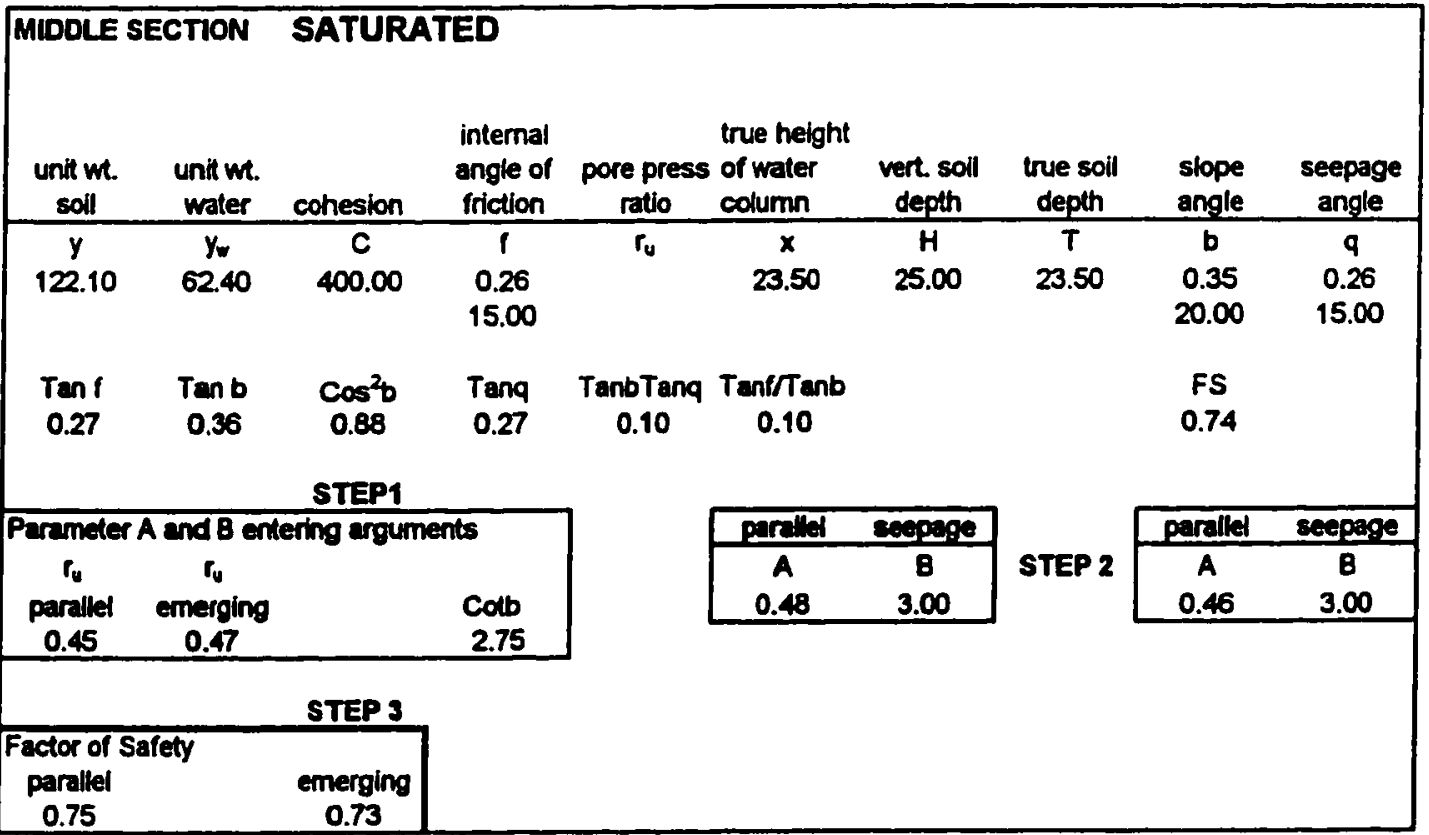




\section{Factor of Safety by Infinite Slope using \\ Parallel / Emerging \\ Seepage}

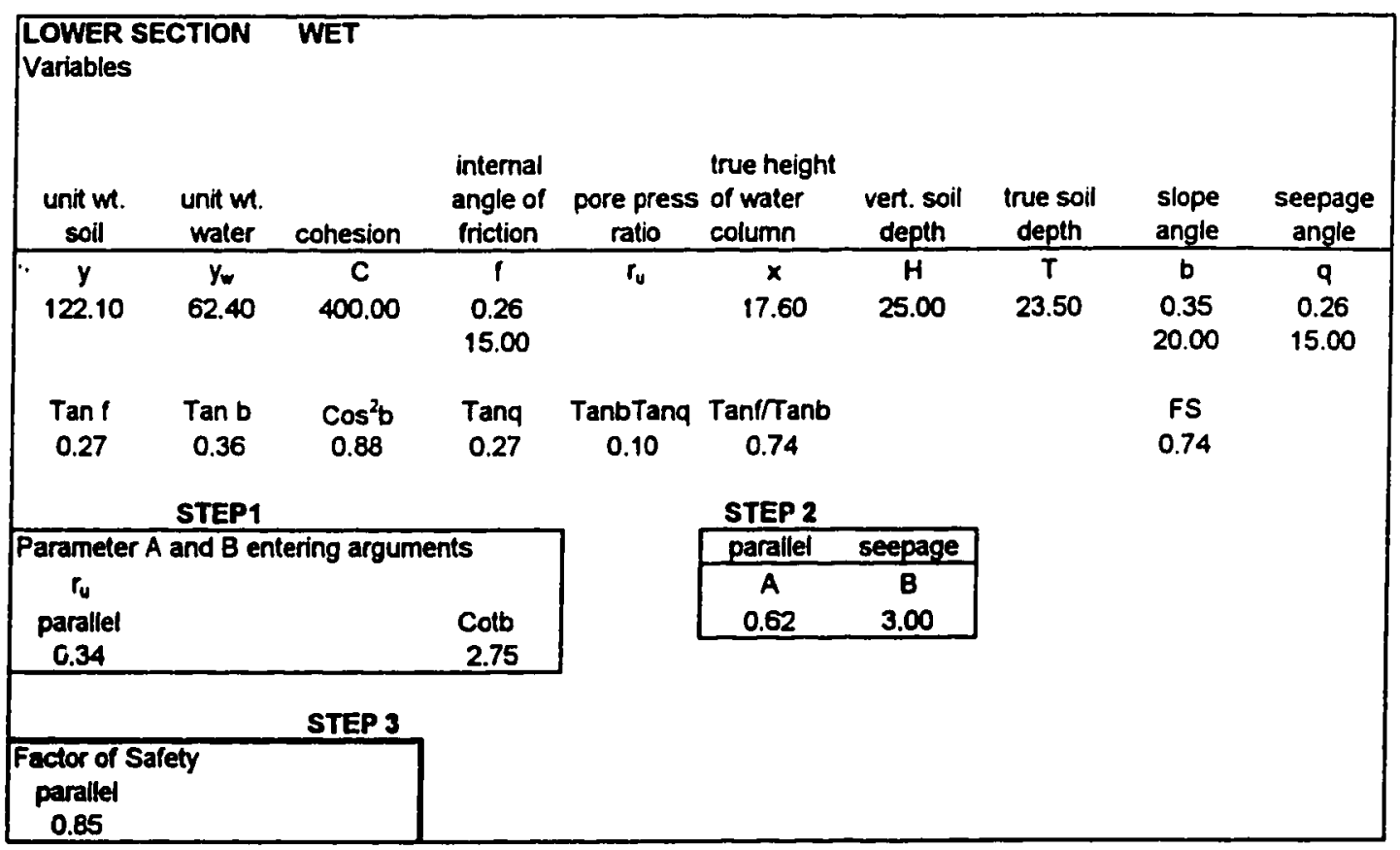

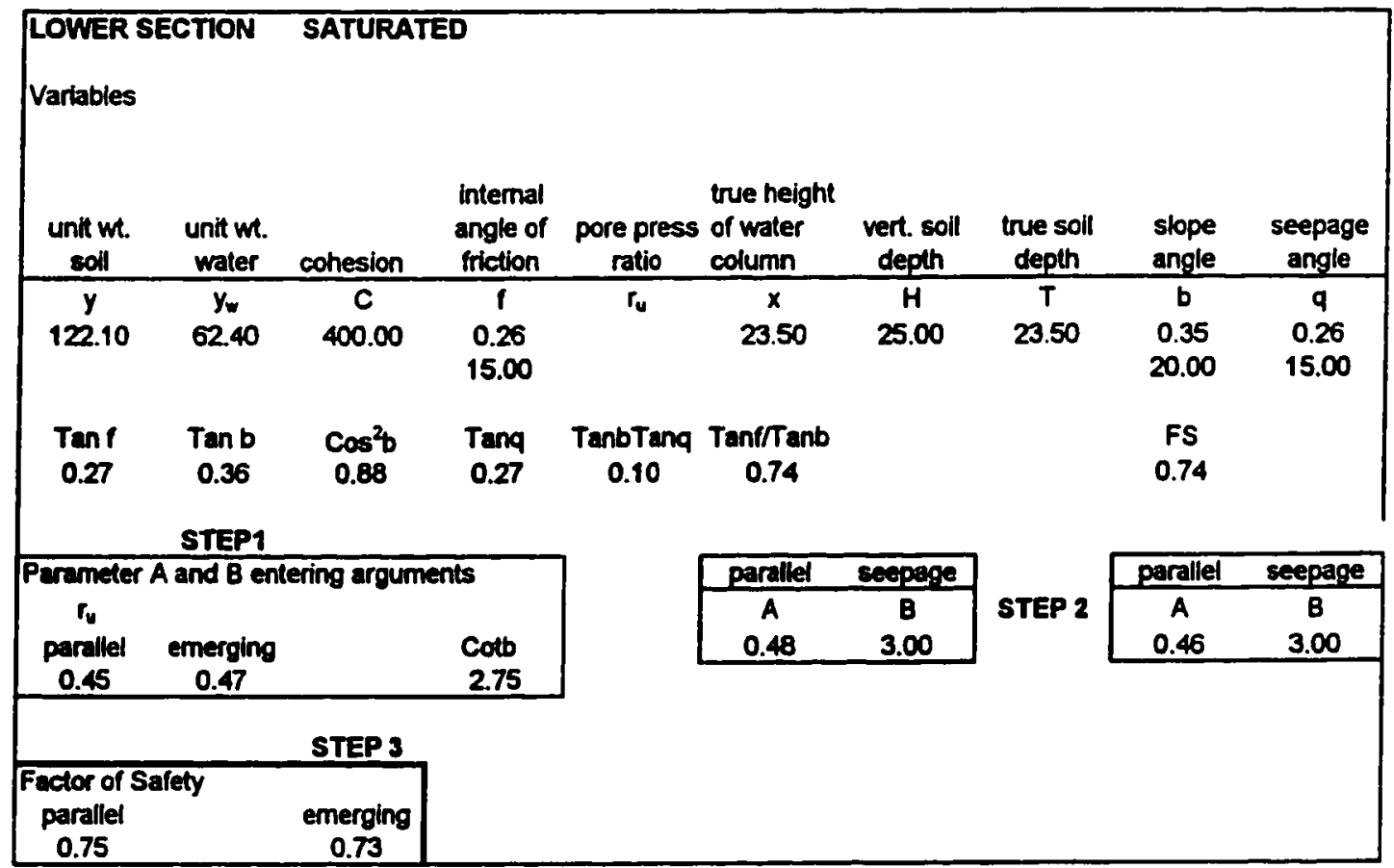


Explanation of calculations utilized in Infinite Slope (with parallel seepage) spreadsheet. Factor of Safety values are calculated along the bedrock/colluvium failure plane for each section under dry, wet. and saturated ground water table conditions. Below is an explanation of the calculations:

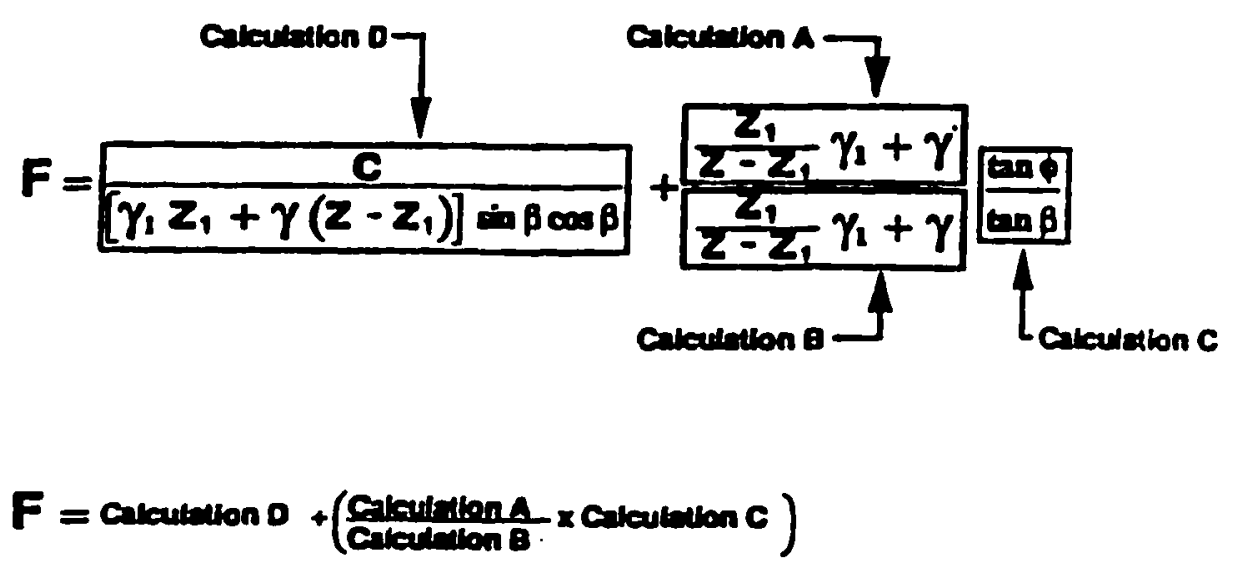

\section{Given that:}

$\gamma_{1}=$ GAMMA1, Soll unit welght above seepage line (water table) (pen)

$\gamma=$ GAMMA, Soil saturated unit weight (pet)

$\gamma^{\prime}=$ GAMMAp, Soll submerged unit weight (pet)

- = PHI, Internal friction angle at fallure surface (deg)

C = COHESION, Cohesion at fallere surface (psi)

$\beta=$ BETA, Slope of the fallure surface (deg)

$Z$ = Thickness of falled material (nt)

$Z_{1}=$ Thickness of falled moterial above the seepage Ine ( $f$.) 
Factor of Safety by Infinite Slope Method

(calculated with seepage)

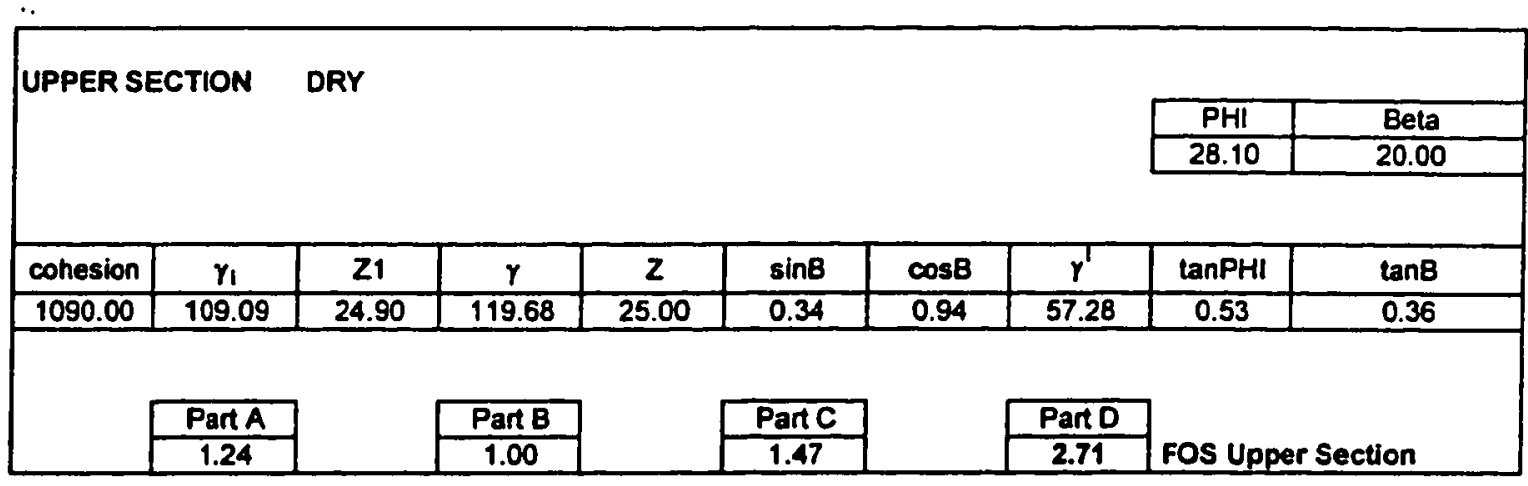

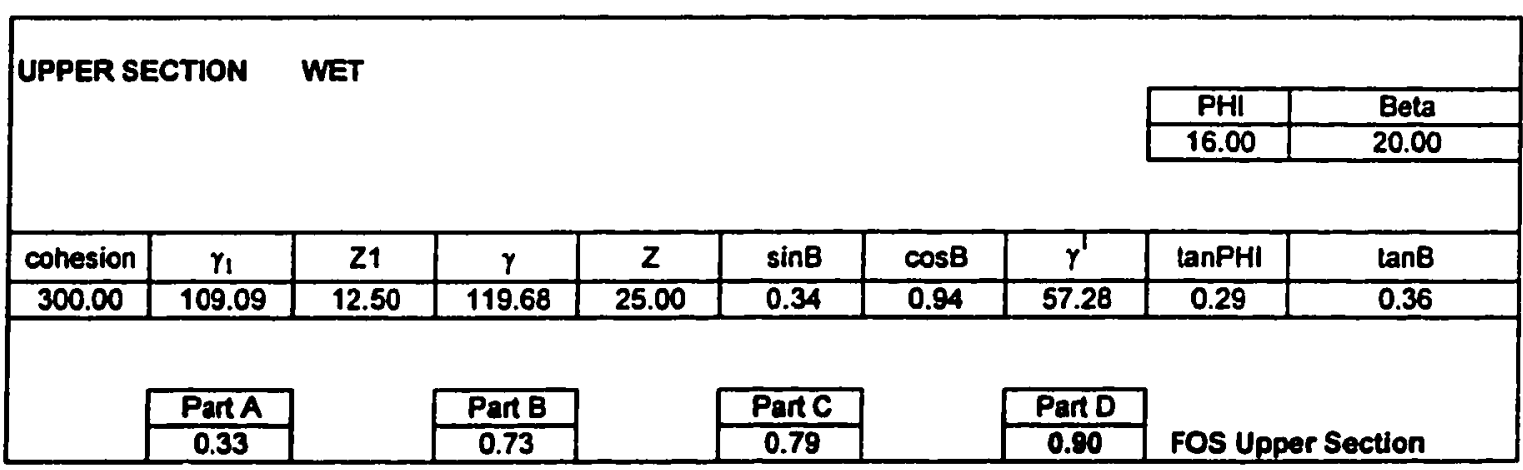

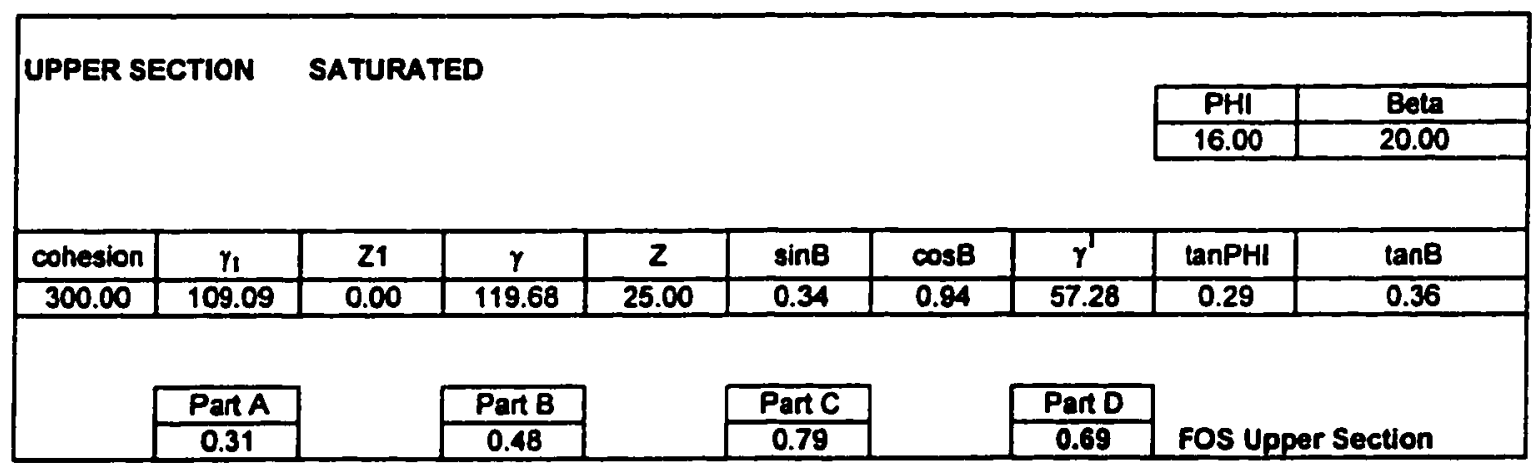


Factor of Safety by Infinite Slope Method

(calculated with seepage)

\begin{tabular}{|c|c|c|c|c|c|c|c|c|c|}
\hline \multicolumn{2}{|c|}{ MIDOLE SECTION } & \multicolumn{6}{|l|}{ DRY } & $\begin{array}{l}\mathrm{PHI} \\
26.10 \\
\end{array}$ & $\begin{array}{l}\text { Beta } \\
20.00\end{array}$ \\
\hline cohesion & $\gamma_{1}$ & $\mathrm{Z1}$ & $\gamma$ & 2 & $\sin B$ & $\cos B$ & $\gamma$ & $\tan \mathrm{PHI}$ & $\tan B$ \\
\hline 1830.00 & 122.10 & 24.90 & 122.80 & 25.00 & 0.34 & 0.94 & 60.40 & 0.49 & 0.36 \\
\hline & $\begin{array}{c}\operatorname{Part} A \\
1.87 \\
\end{array}$ & & $\begin{array}{l}\text { Pan B } \\
1.00 \\
\end{array}$ & & $\begin{array}{l}\text { Part C } \\
1.35 \\
\end{array}$ & & $\frac{P \text { Part D }}{3.21}$ & FOS M: & ction \\
\hline
\end{tabular}

\begin{tabular}{|c|c|c|c|c|c|c|c|c|c|}
\hline \multicolumn{2}{|c|}{ MIDDLE SECTION } & \multicolumn{6}{|l|}{ WET } & $\begin{array}{r}\text { PHI } \\
15.00 \\
\end{array}$ & $\begin{array}{l}\text { Beta } \\
20.00\end{array}$ \\
\hline cohesion & $r_{1}$ & 21 & $\gamma$ & $z$ & $\sin B$ & $\cos B$ & $\gamma$ & $\tan \mathrm{PHI}$ & $\tan B$ \\
\hline 400.00 & 122.10 & 8.25 & 122.80 & 25.00 & 0.34 & 0.94 & 60.40 & 0.27 & 0.36 \\
\hline & $\begin{array}{c}\text { Part A } \\
0.41\end{array}$ & & $\frac{\text { Pant B }}{0.66}$ & & $\frac{\text { Part C }}{0.74}$ & & $\frac{\text { PartD }}{0.89}$ & FOS Mi & ection \\
\hline
\end{tabular}

\begin{tabular}{|c|c|c|c|c|c|c|c|c|c|}
\hline \multicolumn{2}{|c|}{ MIDOLE SECTION } & \multicolumn{6}{|c|}{ SATURATED } & $\begin{array}{c}\mathrm{PHI} \\
15.00 \\
\end{array}$ & $\frac{\text { Beta }}{20.00}$ \\
\hline cohesion & $\gamma_{1}$ & 21 & $\gamma$ & 2 & $\sin B$ & $\cos B$ & $\gamma$ & tanPHI & $\tan B$ \\
\hline 400.00 & 122.10 & 0.00 & 122.80 & 25.00 & 0.34 & 0.94 & 60.40 & 0.27 & 0.36 \\
\hline & $\begin{array}{l}\text { Part A } \\
0.41 \\
\end{array}$ & & $\begin{array}{c}\text { Pant B } \\
0.49 \\
\end{array}$ & & $\frac{\text { Pan C }}{0.74}$ & & $\begin{array}{l}\text { Part D } \\
0.77 \\
\end{array}$ & FOS Mi & etion \\
\hline
\end{tabular}


Factor of Safety by Infinite Slope Method

(calculated with seepage)

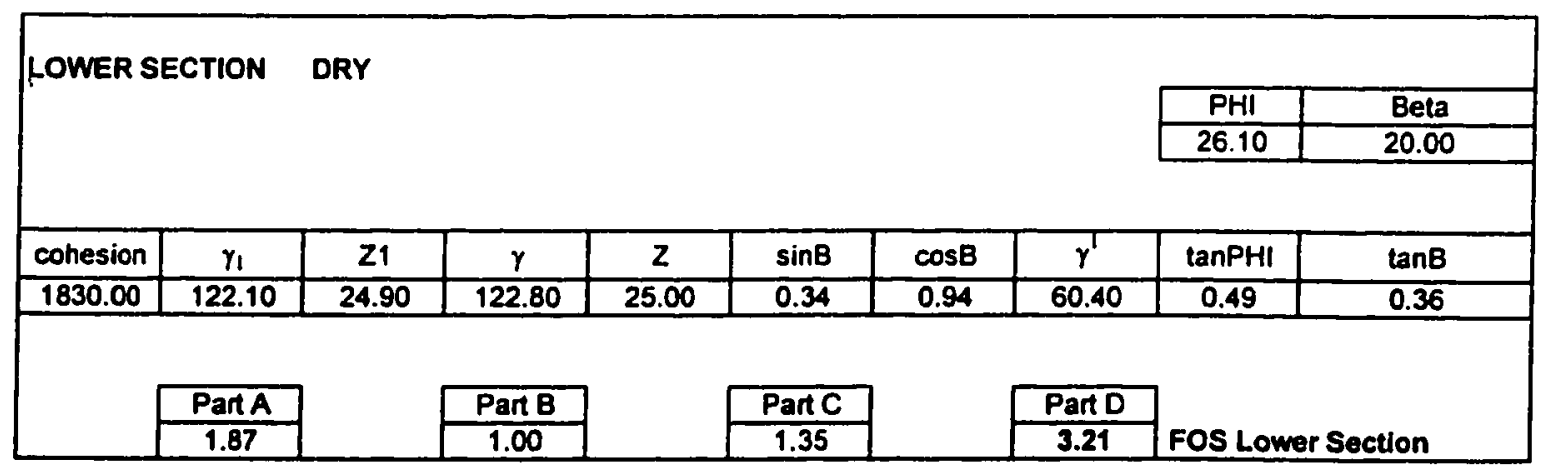

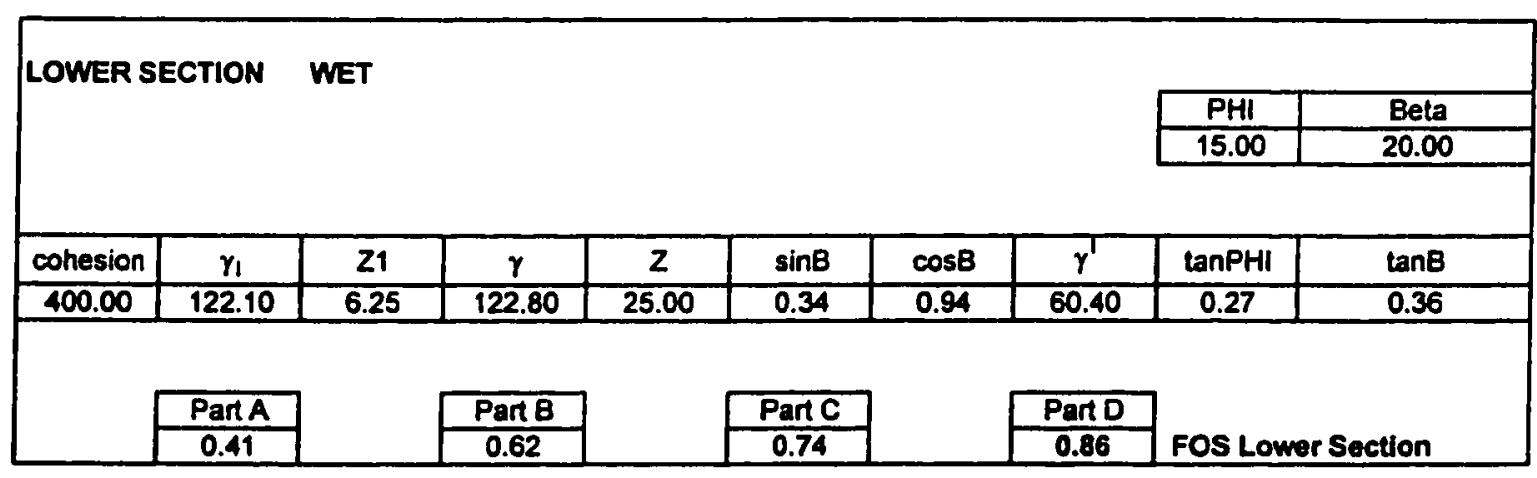

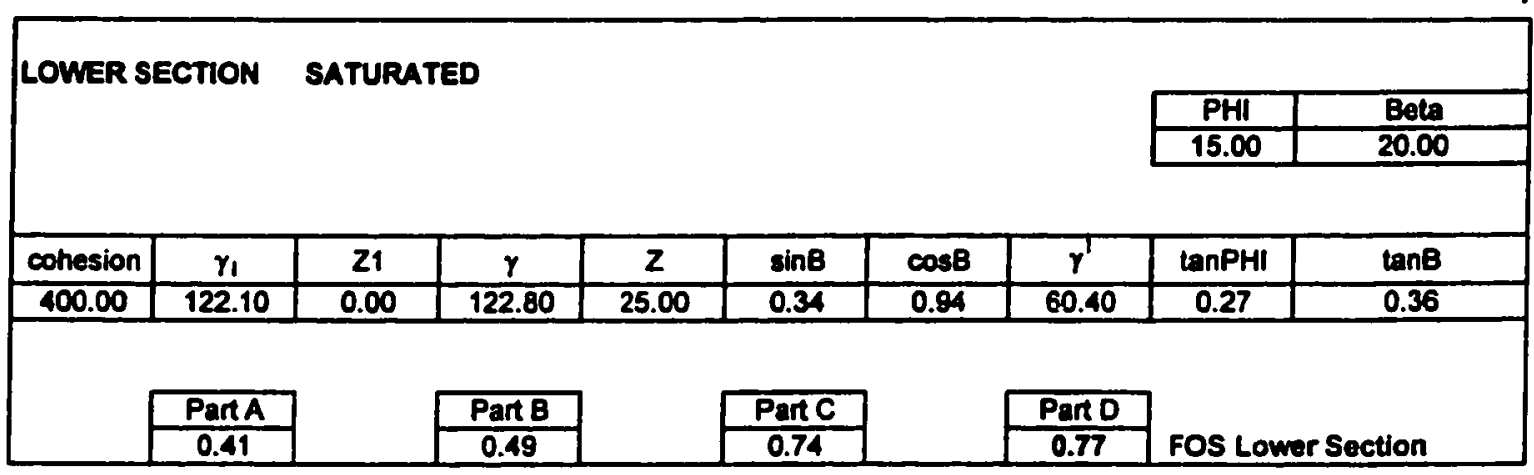


APPENDIX C

SOIL ANALYSIS 
Field investigation revealed that the middle and lower sections are of similar material, therefore middle section samples were not taken. The following pages report the results of laboratory soil analysis from samples taken from the upper and lower sections of Cleveland Corral. These include sieve and hydrometer grain-size analysis, grain-size distribution curves, liquid limits and plastic limits, weights and volumes, and unconsolidated-undrained direct shear results. Unconsolidated-undrained direct shear testing was conducted by Cooper Testing Labs of Mountain View, CA. 

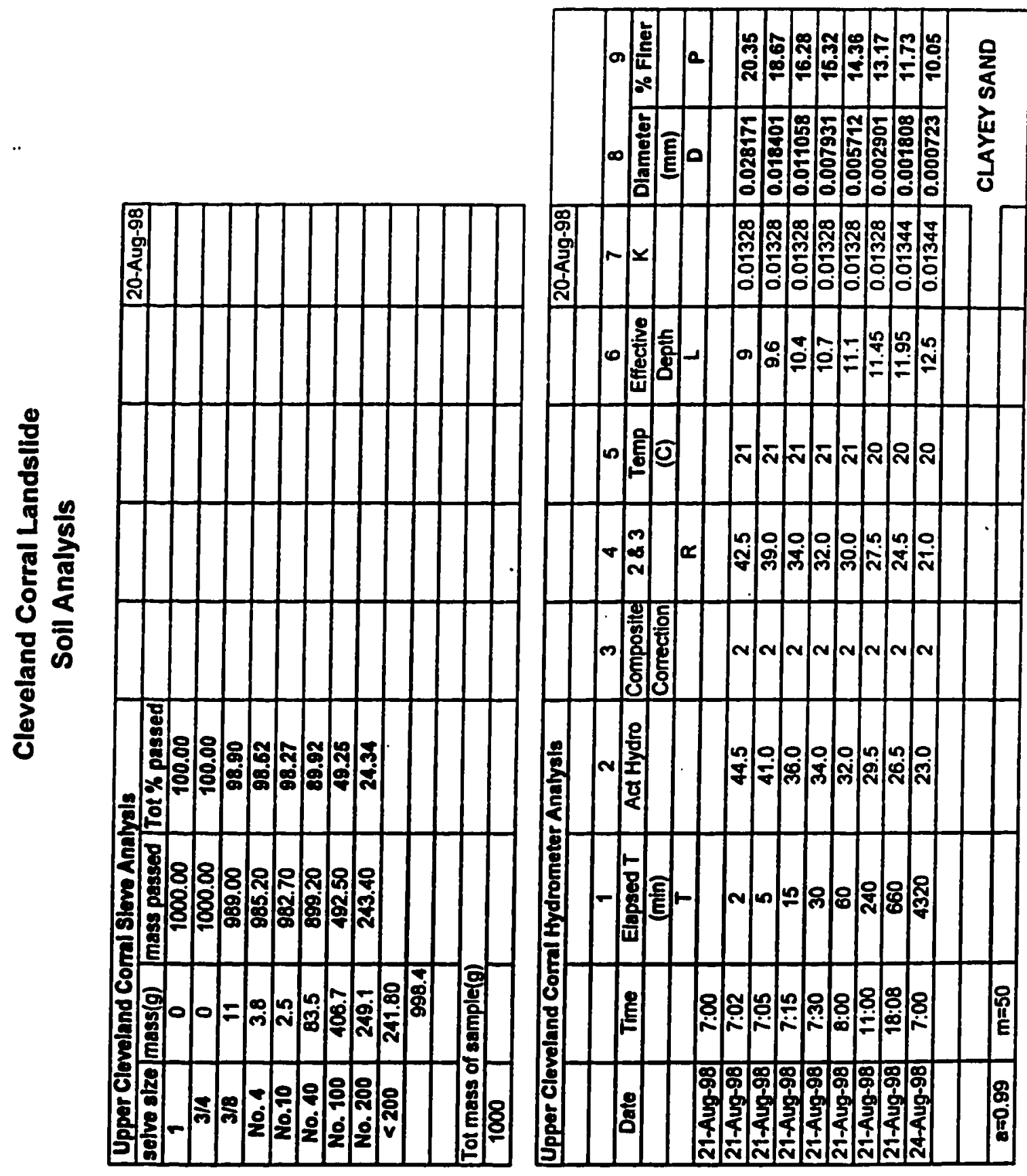


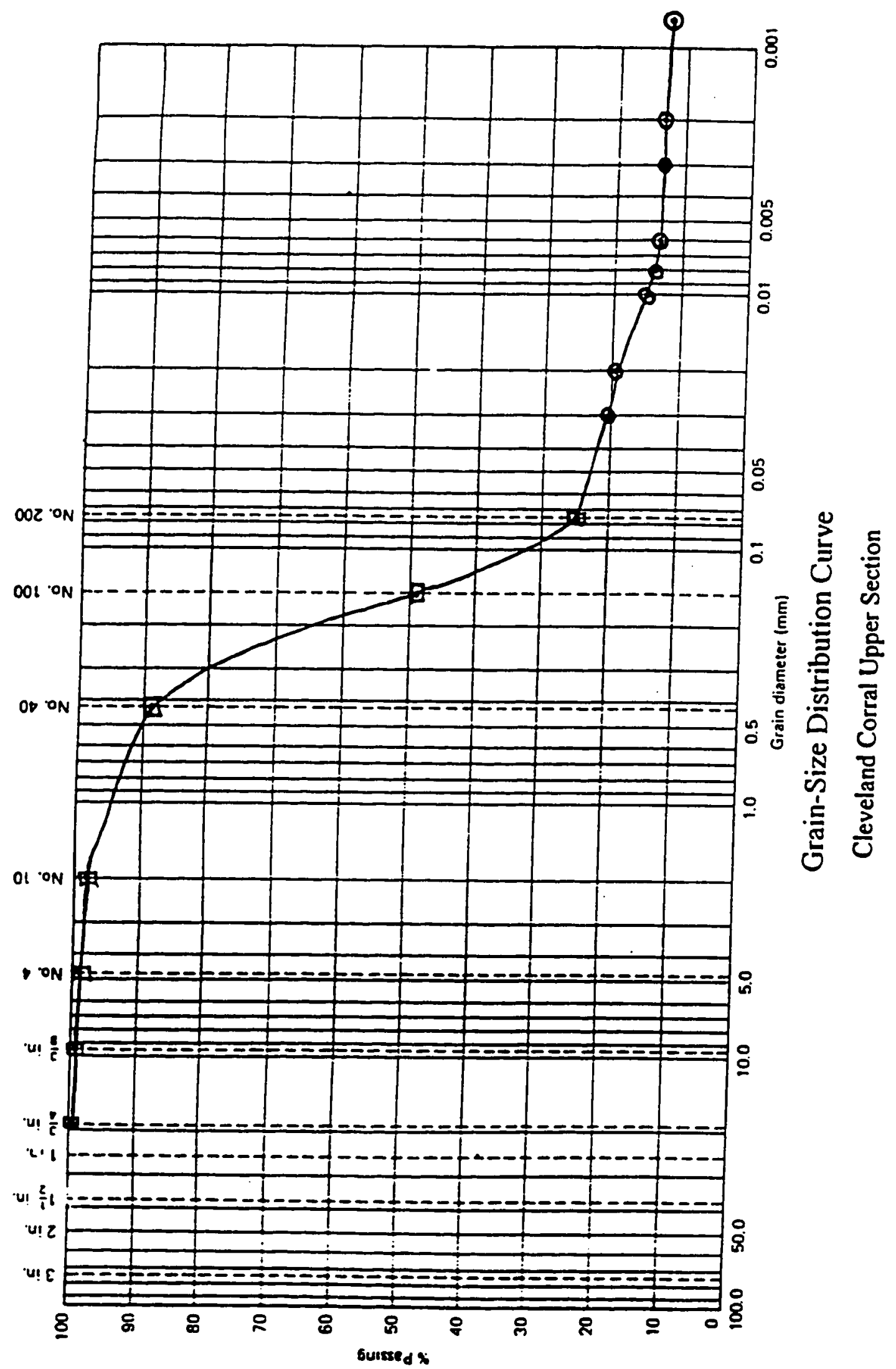



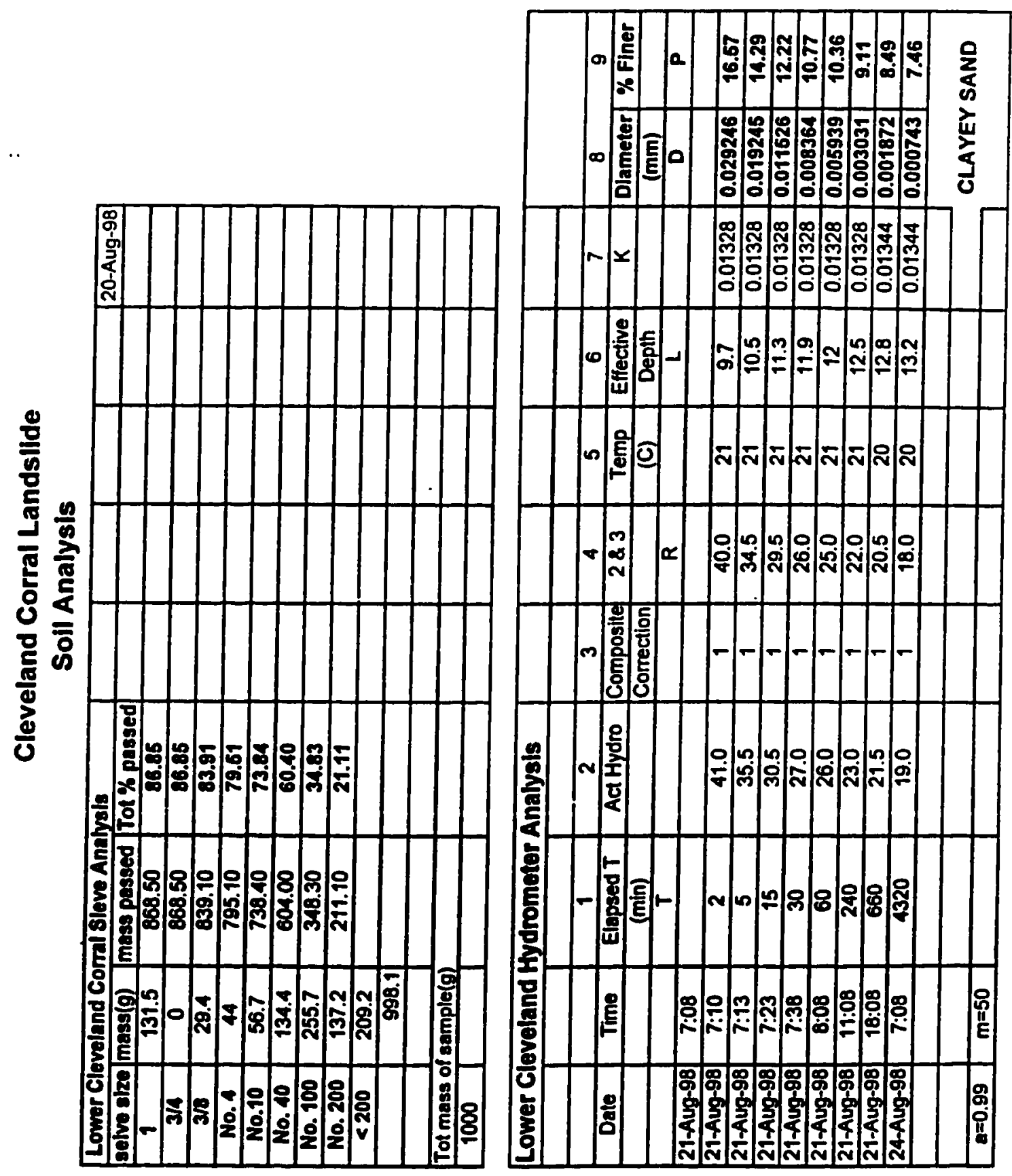


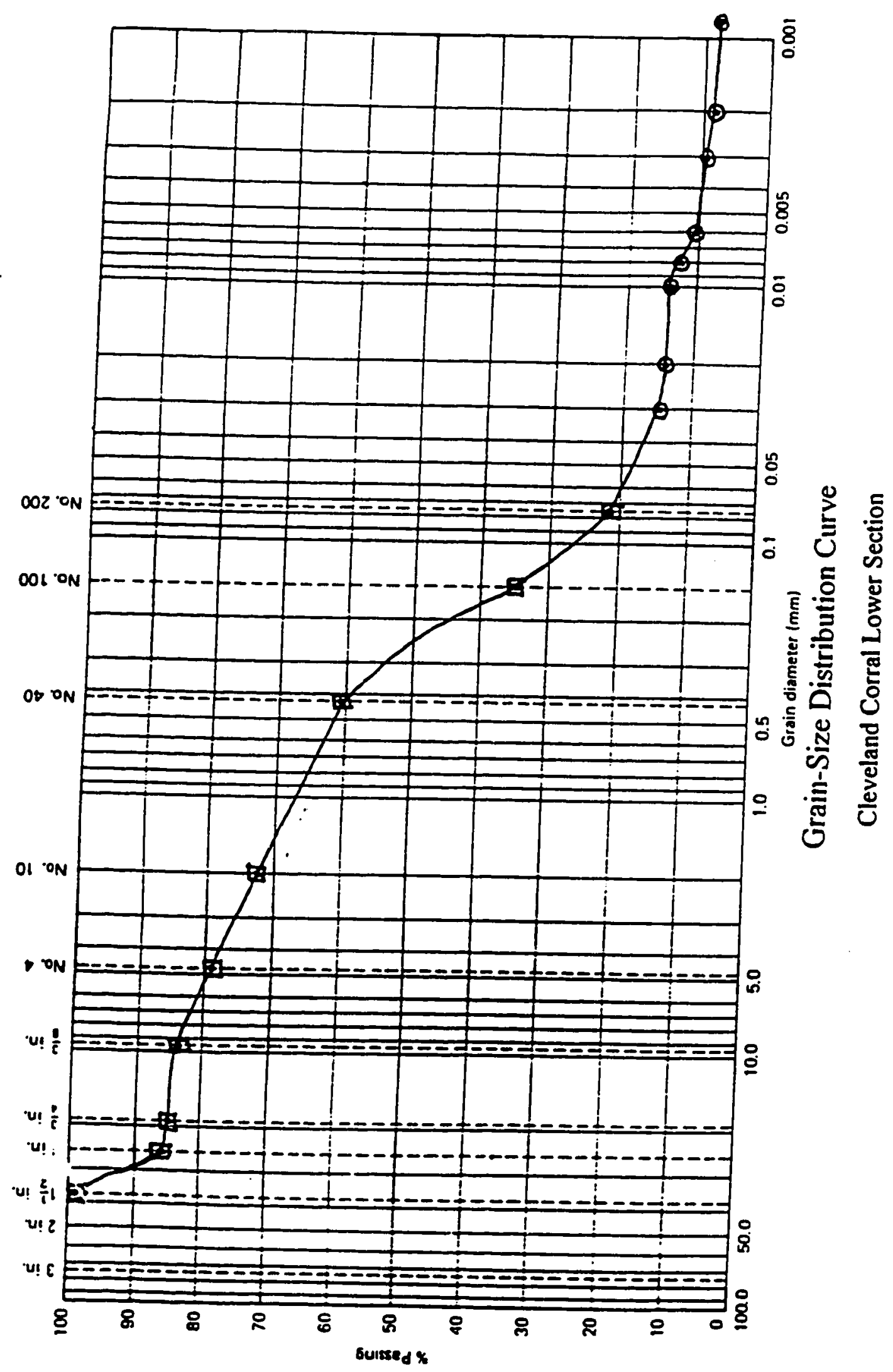




\section{Liquid Limits Determination}

Cleveland Corral Landslide

\section{Lower Section}

Clayey Sand

\begin{tabular}{|l|l|l|l|l|}
\hline Determinatior \# & 1 & 2 & 3 & 4 \\
\hline Number of drops & 35 & 16 & 20 & 26 \\
\hline Can number & L1 & L2 & L3 & L4 \\
\hline Mass of can + moist (g) & 61.2 & 55.3 & 58.4 & 51.5 \\
\hline Mass of can + dry soil (g) & 58.4 & 52.6 & 55.0 & 48.0 \\
\hline Mass of can (g) & 47.8 & 44.0 & 43.1 & 35.2 \\
\hline Mass of water (g) & 2.8 & 2.7 & 3.4 & 3.5 \\
\hline Mass of dry soil (g) & 10.6 & 8.6 & 11.9 & 12.8 \\
\hline Moisture Content (\%) & 26.4 & 31.4 & 28.6 & 27.3 \\
\hline
\end{tabular}

From the flow curve: Lower Section Liquid Limit $=28 \%$

\section{Upper Section}

Clayey Sand

\begin{tabular}{|l|l|l|l|}
\hline $\begin{array}{l}\text { Determination \# } \\
.\end{array}$ & 1 & 2 & 3 \\
\hline Number of drops & 47 & 30 & 20 \\
\hline Can number & $\mathrm{U} 1$ & $\mathrm{U} 2$ & $\mathrm{U} 3$ \\
\hline Mass of can + moist (g) & 32.5 & 44.7 & 36.0 \\
\hline Mass of can + dry soil (g) & 29.4 & 40.8 & 31.8 \\
\hline Mass of can (g) & 20.6 & 30.4 & 21.9 \\
\hline Mass of water (g) & 3.1 & 3.9 & 4.2 \\
\hline Mass of dry soil (g) & 8.8 & 10.4 & 9.9 \\
\hline Moisture Content (\%) & 35.2 & 37.5 & 42.4 \\
\hline
\end{tabular}

From the flow curve: Upper Section Liquid Limit $=39.8 \%$ 


\section{Plastic Limits Determination}

Cleveland Corral Landslide

Lower Section

\begin{tabular}{|l|l|l|}
\hline Determination \# & $\mathrm{l}$ & 2 \\
\hline Can \# & $\mathrm{Ll}$ & $\mathrm{L} 2$ \\
\hline Mass of can + moist soil (g) & 32.3 & 37.1 \\
\hline Mass of can + dry soil (g) & 30.5 & 35.4 \\
\hline Mass of can (g) & 21.9 & 25.4 \\
\hline Mass of water (g) & 1.8 & 1.7 \\
\hline Mass of dry soil (g) & 8.6 & 10.0 \\
\cline { 1 - 2 } Water Content (\%) & 20.9 & 17.0 \\
\hline Plastic Limit (\%) & 19.0 & \multirow{2}{*}{} \\
\cline { 1 - 2 } Plasticity Index (\%) & 9.0 & \\
\cline { 1 - 2 } & &
\end{tabular}

\section{Upper Section}

\begin{tabular}{|l|l|l|}
\hline Determination \# & 1 & 2 \\
\hline Can \# & U1 & U2 \\
\hline Mass of can + moist soil (g) & 36.5 & 28.0 \\
\hline Mass of can + dry soil (g) & 34.2 & 25.9 \\
\hline Mass of can (g) & 22.5 & 22.5 \\
\hline Mass of water (g) & 2.3 & 2.1 \\
\hline Mass of dry soil (g) & 11.7 & 10.0 \\
\cline { 1 - 2 } & & \\
\hline Water Content (\%) & 20.9 & 17.0 \\
\cline { 1 - 2 } Plastic Limit (\%) & 20.1 & \\
\cline { 1 - 2 } Plasticity Index (\%) & 19.7 & \\
\cline { 1 - 2 } & &
\end{tabular}


SJSU Soil Analysis of Cleveland Corral Landslide Sample: Upper Section

\begin{tabular}{|l|l|}
\hline Total Volume (cf) & 0.011 \\
\hline Specific Gravity (assumed) & 2.7 \\
\hline Wet soil + pan (lbs) & 3.019 \\
\hline Pan (lbs) & 1.818 \\
\hline Wet Soil (lbs) & 1.201 \\
\hline Dry Soil + Pan (lbs) & 2.826 \\
\hline Dry Soil (lbs) & 1.001 \\
\hline Water (lbs) & .2 \\
\hline
\end{tabular}

$$
\begin{aligned}
& \mathrm{V}_{\mathrm{w}}=\mathrm{W}_{\mathrm{w}} / \gamma_{\mathrm{w}} \quad 0.2 \mathrm{lb} / 62.4 \mathrm{lb} \mathrm{pcf}=0.0032 \mathrm{cf} \\
& \mathrm{V}_{\mathrm{s}}=\mathrm{W}_{\mathrm{s}} / \mathrm{G}_{\mathrm{w}} \quad 1.001 \mathrm{lb} /(2.7)(62.4 \mathrm{pcf})=0.00594 \mathrm{cf} \\
& V_{t}=V_{t}-\left(V_{w}+V_{s}\right) \quad 0.011 c f-(0.0032 c f+0.00594 c f)=0.00186 c f \\
& \mathrm{~V}_{\mathrm{v}}=\mathrm{V}_{\mathrm{a}}+\mathrm{V}_{\mathrm{w}} \quad 0.00186 \mathrm{cf}+0.0032 \mathrm{cf}=0.00506 \mathrm{cf} \\
& \gamma_{\text {wet }}=\mathrm{W}_{\mathrm{l}} / \mathrm{V}_{\mathrm{t}} \quad 1.2 \mathrm{lb} / 0.011 \mathrm{cf}=109.09 \mathrm{pcf} \\
& \gamma_{\text {dry }}=\mathrm{W}_{\mathrm{s}} / \mathrm{V}_{\mathrm{t}} \quad 1.001 \mathrm{lb} / 0.011 \mathrm{cf}=91.0 \mathrm{pcf} \\
& \mathrm{W}_{\text {sub }}=\mathrm{Vs} \cdot \gamma_{\mathrm{w}} \cdot\left(\mathrm{G}_{\mathrm{s}}-1\right) \quad(0.00594 \mathrm{cf})(62.4 \mathrm{pcf})(1.7)=0.63012 \mathrm{lbs} \\
& \gamma_{\text {sub }}=W_{\text {sub }} / V_{1} \quad 0.63012 \mathrm{lb} / 0.011 \mathrm{cf}=57.283 \mathrm{pcf} \\
& \gamma_{\text {sat }}=\gamma_{\text {sub }}+\gamma_{\text {wat }} \quad 57.283 \mathrm{pcf}+62.4 \mathrm{pcf}=119.683 \mathrm{pcf} \\
& \mathrm{e}=\mathrm{V}_{\mathrm{v}} / \mathrm{V}_{\mathrm{s}} \quad 0.00506 \mathrm{cf} / 0.00594 \mathrm{cf}=0.8518 \\
& \mathrm{~S}=\mathrm{V}_{\mathrm{w}} / \mathrm{V}_{\mathrm{v}} \quad 0.0032 \mathrm{cf} / 0.00506 \mathrm{cf}=63.2 \% \\
& \mathrm{n}=\mathrm{V}_{\mathrm{v}} / \mathrm{V}_{\mathrm{t}} \quad 0.00506 \mathrm{cf} / 0.01 \mathrm{cf}=46.0 \% \\
& w=W w / W s \quad 0.20 \mathrm{lb} / 1.001 \mathrm{lb}=19.98 \%
\end{aligned}
$$


SJSU Soil Analysis of Cleveland Corral Landslide Sample: Lower Section

\begin{tabular}{|l|l|}
\hline Total Volume (cf) & 0.011 \\
\hline Specific Gravity (assumed) & 2.7 \\
\hline Wet soil + pan (lbs) & 2.714 \\
\hline Pan (lbs) & 1.371 \\
\hline Wet Soil (lbs) & 1.343 \\
\hline Dry Soil + Pan (lbs) & 2.426 \\
\hline Dry Soil (lbs) & 1.055 \\
\hline Water (lbs) & 0.288 \\
\hline
\end{tabular}

$$
\begin{aligned}
& \mathrm{V}_{\mathrm{w}}=\mathrm{W}_{\mathrm{w}} / \gamma_{\mathrm{w}} \quad 0.288 \mathrm{lb} / 62.4 \mathrm{lb} \mathrm{pcf}=0.00462 \mathrm{cf} \\
& V_{s}=W_{s} / G \gamma_{w} \quad 1.055 \mathrm{lb} /(2.7)(62.4 \mathrm{pcf})=0.00626 \mathrm{cf} \\
& V_{z}=V_{t}-\left(V_{w}+V_{s}\right) \quad 0.011 c f-(0.0046 c f+0.0063 c f)=0.00012 c f \\
& \mathrm{~V}_{\mathrm{v}}=\mathrm{V}_{\mathrm{a}}+\mathrm{V}_{\mathrm{w}} \quad 0.00012 \mathrm{cf}+0.00462 \mathrm{cf}=0.00474 \mathrm{cf} \\
& \gamma_{\text {wet }}=W_{\mathrm{t}} / \mathrm{V}_{\mathrm{t}} \quad 1.343 \mathrm{lb} / 0.011 \mathrm{cf}=122.1 \mathrm{pcf} \\
& \gamma_{\mathrm{dry}}=\mathrm{W}_{s} / \mathrm{V}_{\mathrm{l}} \quad 1.055 \mathrm{lb} / 0.011 \mathrm{cf}=95.9 \mathrm{pcf} \\
& \mathrm{W}_{\text {sub }}=V_{s s} \cdot \gamma_{\mathrm{w}} \cdot\left(\mathrm{G}_{\mathrm{s}}-1\right) \quad(0.00626 \mathrm{cf})(62.4 \mathrm{pcf})(1.7)=0.66406 \mathrm{lbs} \\
& \gamma_{\text {sub }}=\mathrm{W}_{\text {sub }} / \mathrm{V}_{\mathrm{l}} \quad 0.66406 \mathrm{lb} / 0.01 \mathrm{lcf}=60.369 \mathrm{pcf} \\
& \gamma_{\text {sut }}=\gamma_{\text {sub }}+\gamma_{\text {wat }} \quad 60.369 \mathrm{pcf}+62.4 \mathrm{pcf}=122.796 \mathrm{pcf} \\
& e=V_{v} / V_{s} \quad 0.00474 c f / 0.00626 c f=0.757 \\
& S=V_{w} / V_{v} \quad 0.00462 \mathrm{cf} / 0.00474 \mathrm{cf}=97.5 \% \\
& \mathrm{n}=\mathrm{V}_{\mathrm{v}} / \mathrm{V}_{\mathrm{l}} \quad 0.0474 \mathrm{cf} / 0.01 \mathrm{cf}=43.1 \% \\
& w=W_{w} / W_{s} \quad 0.288 \mathrm{lb} / 1.055 \mathrm{lb}=27.2 \%
\end{aligned}
$$




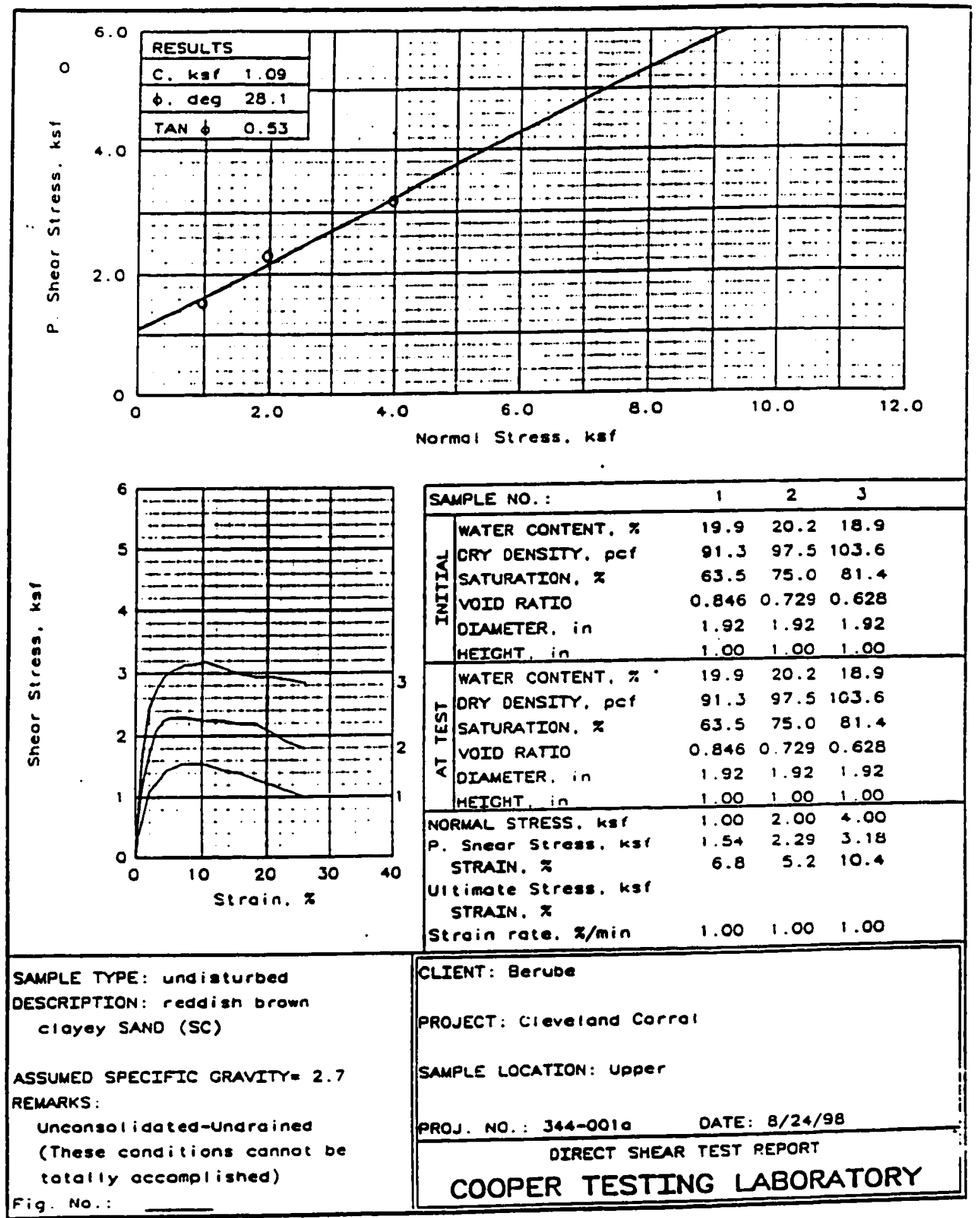




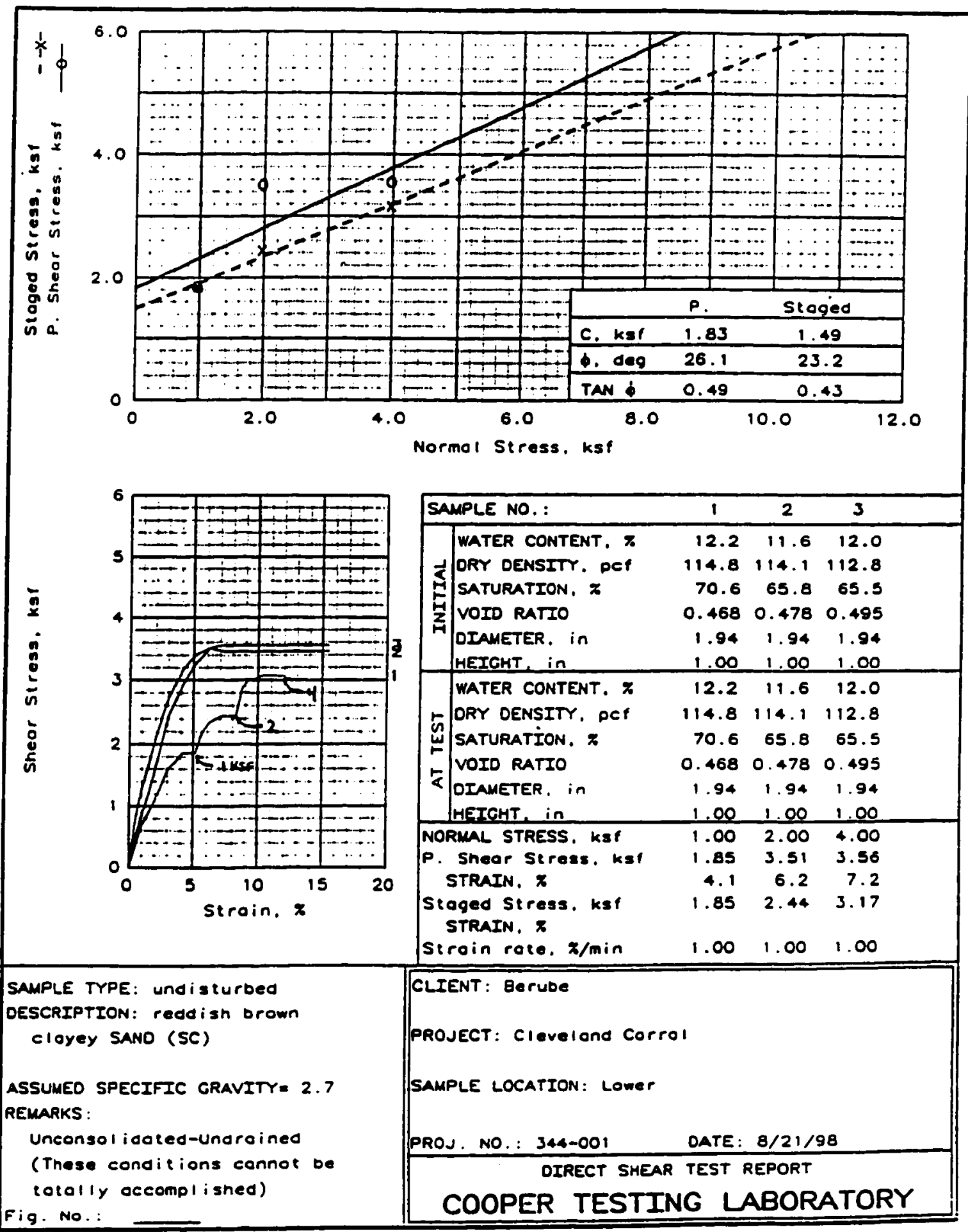




\section{NOTE TO USERS}

Oversize maps and charts are microfilmed in sections in the following manner:

\section{LEFT TO RIGHT, TOP TO BOTTOM, WITH SMALL OVERLAPS}

The following map or chart has been microfilmed in its entirety at the end of this manuscript (not available on microfiche). A xerographic reproduction has been provided for paper copies and is inserted into the inside of the back cover.

Black and white photographic prints (17'x 23") are available for an additional charge. 


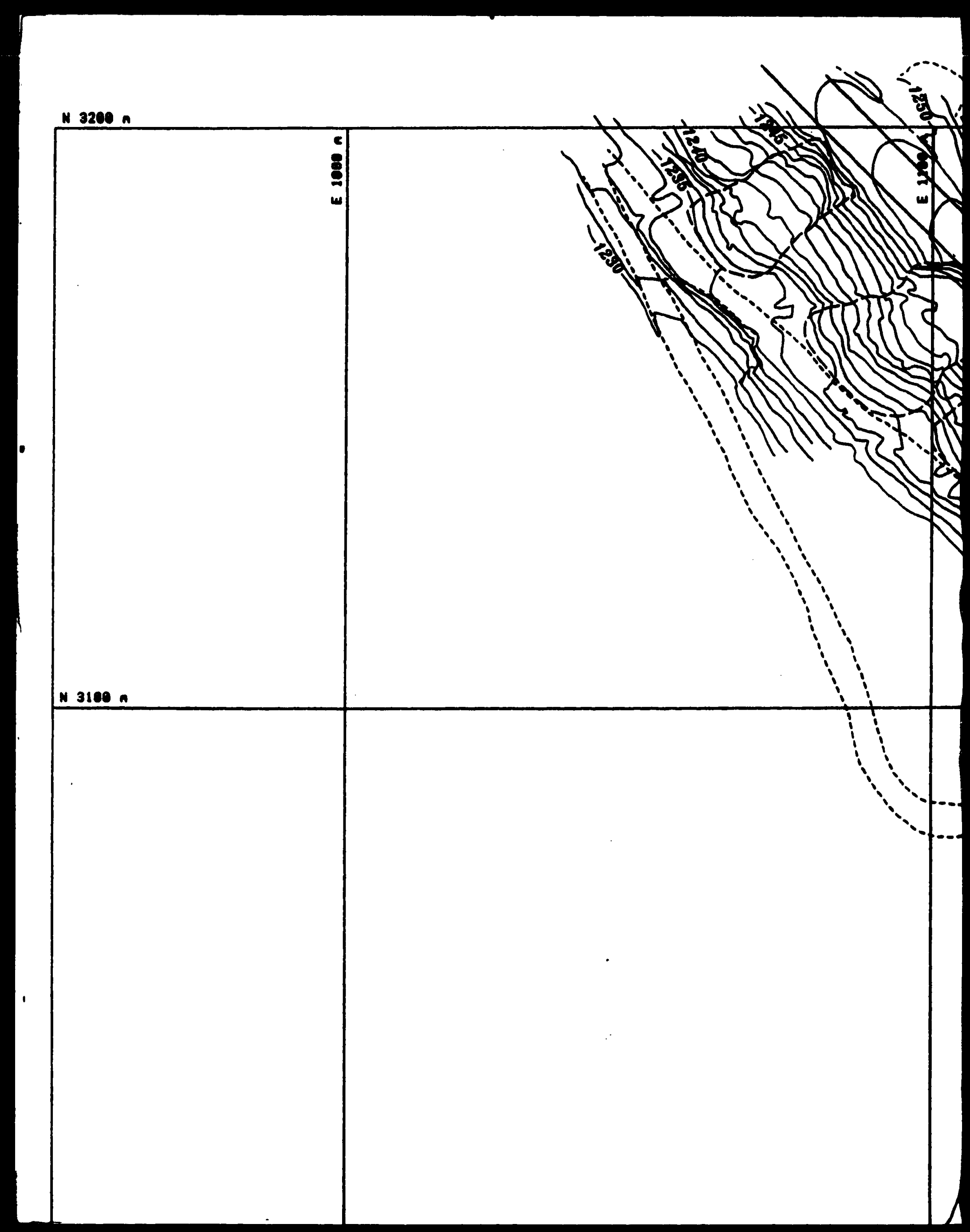




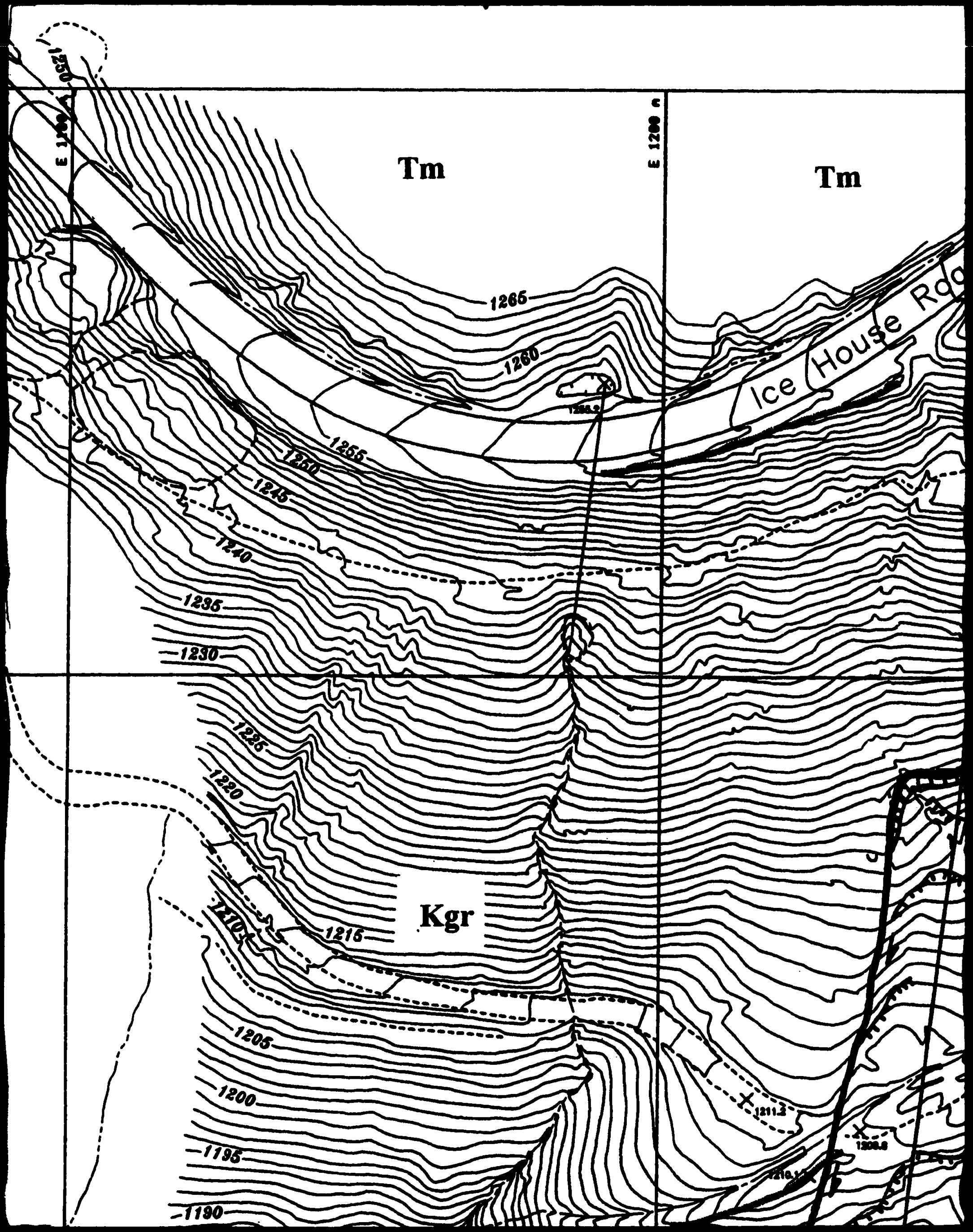




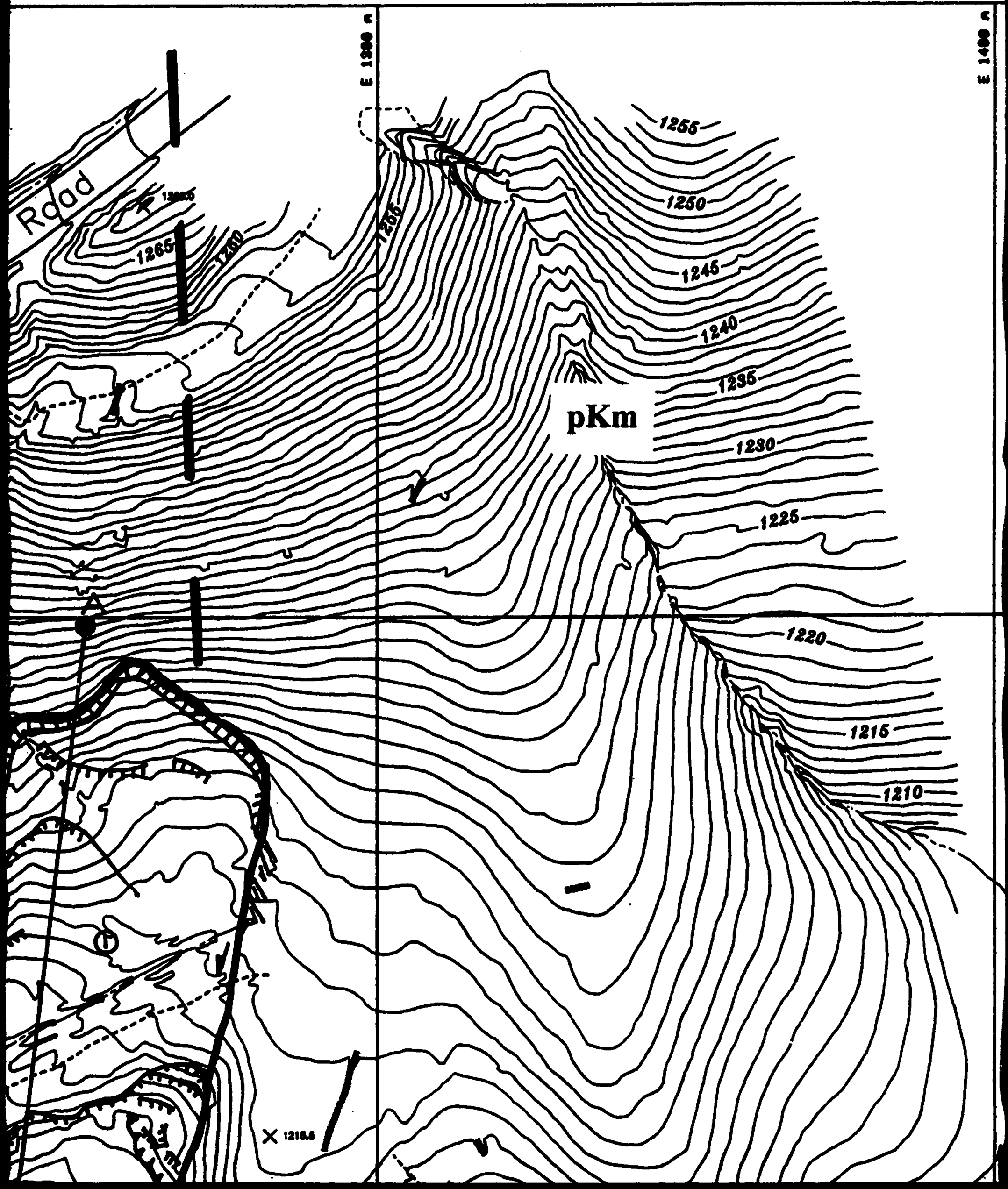




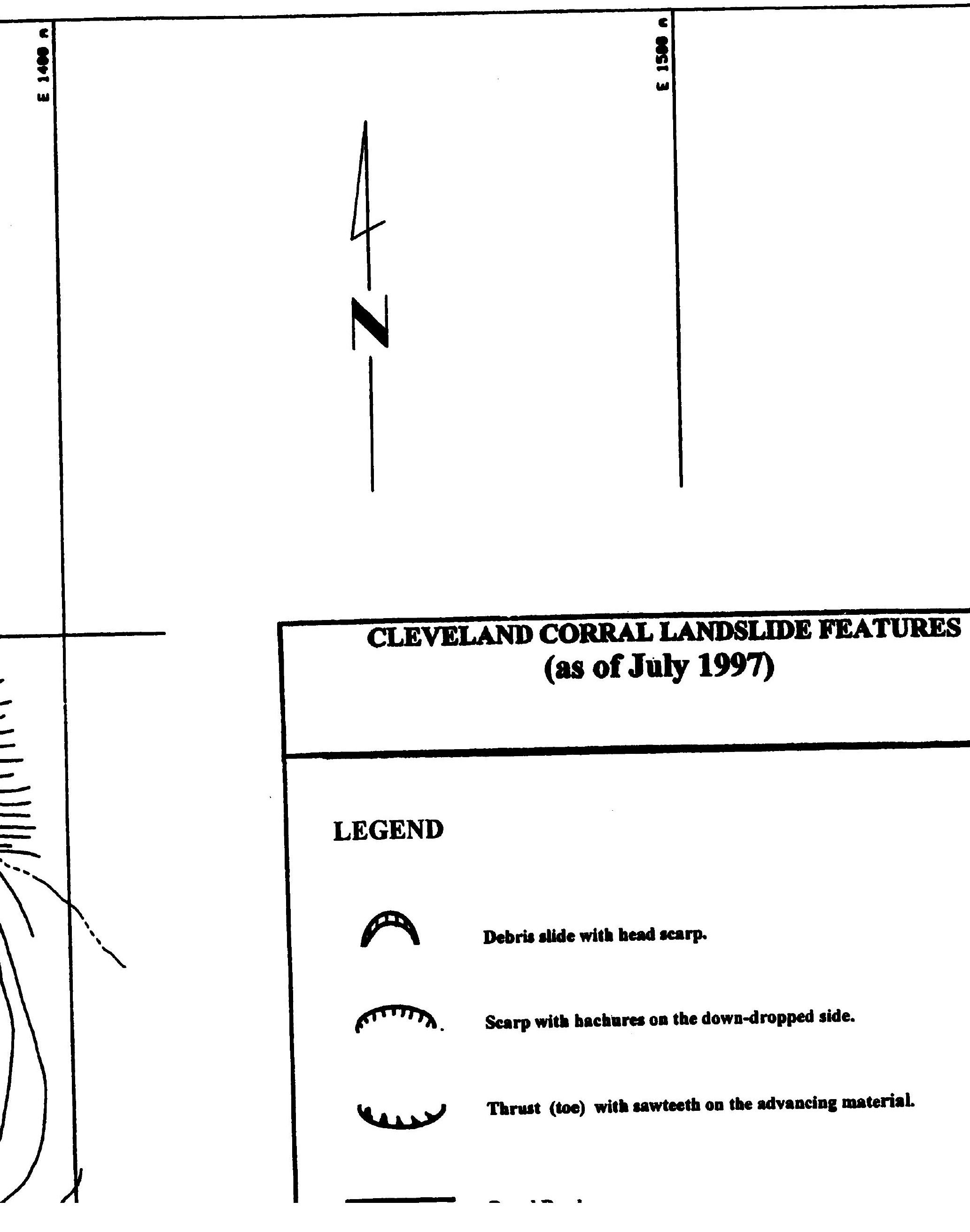



(as of July 1997)

\section{GEND}

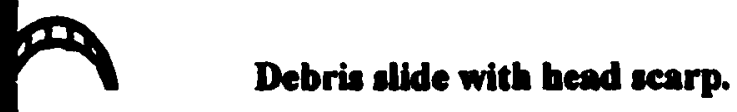

IIIT. Scarp with bachures on the down-dropped side.

Ww Thruat (too) with sawteeth on the advancing material. 


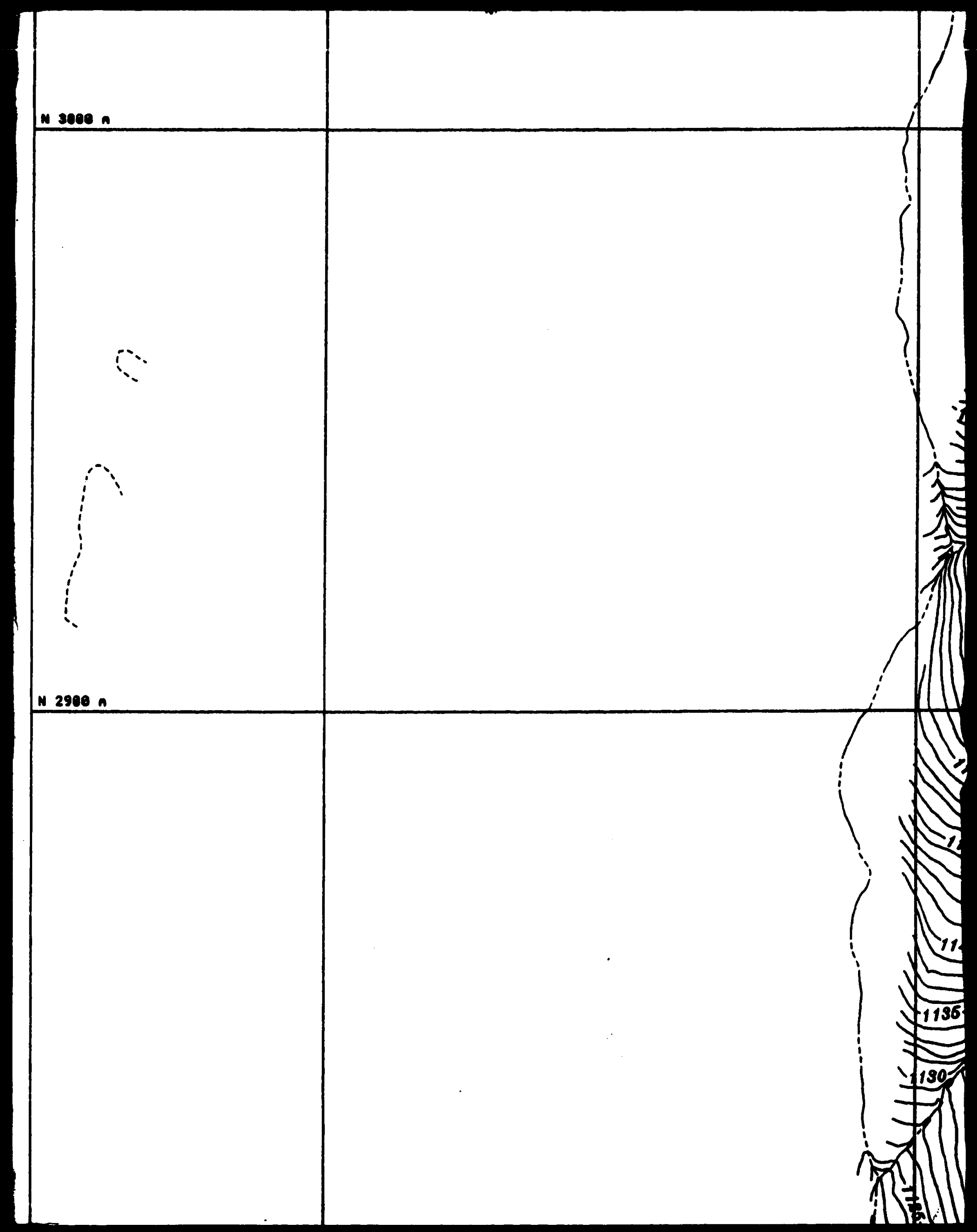




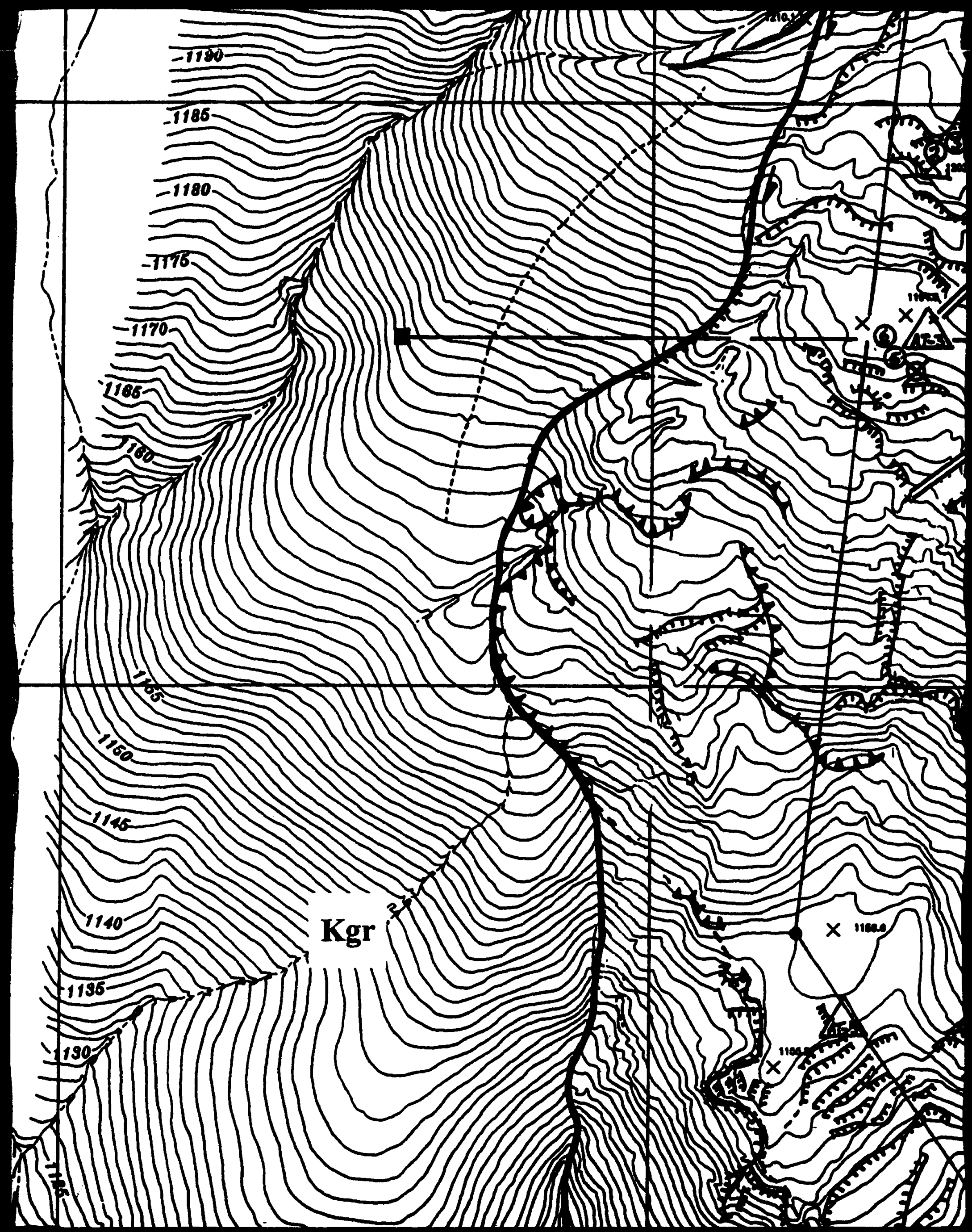




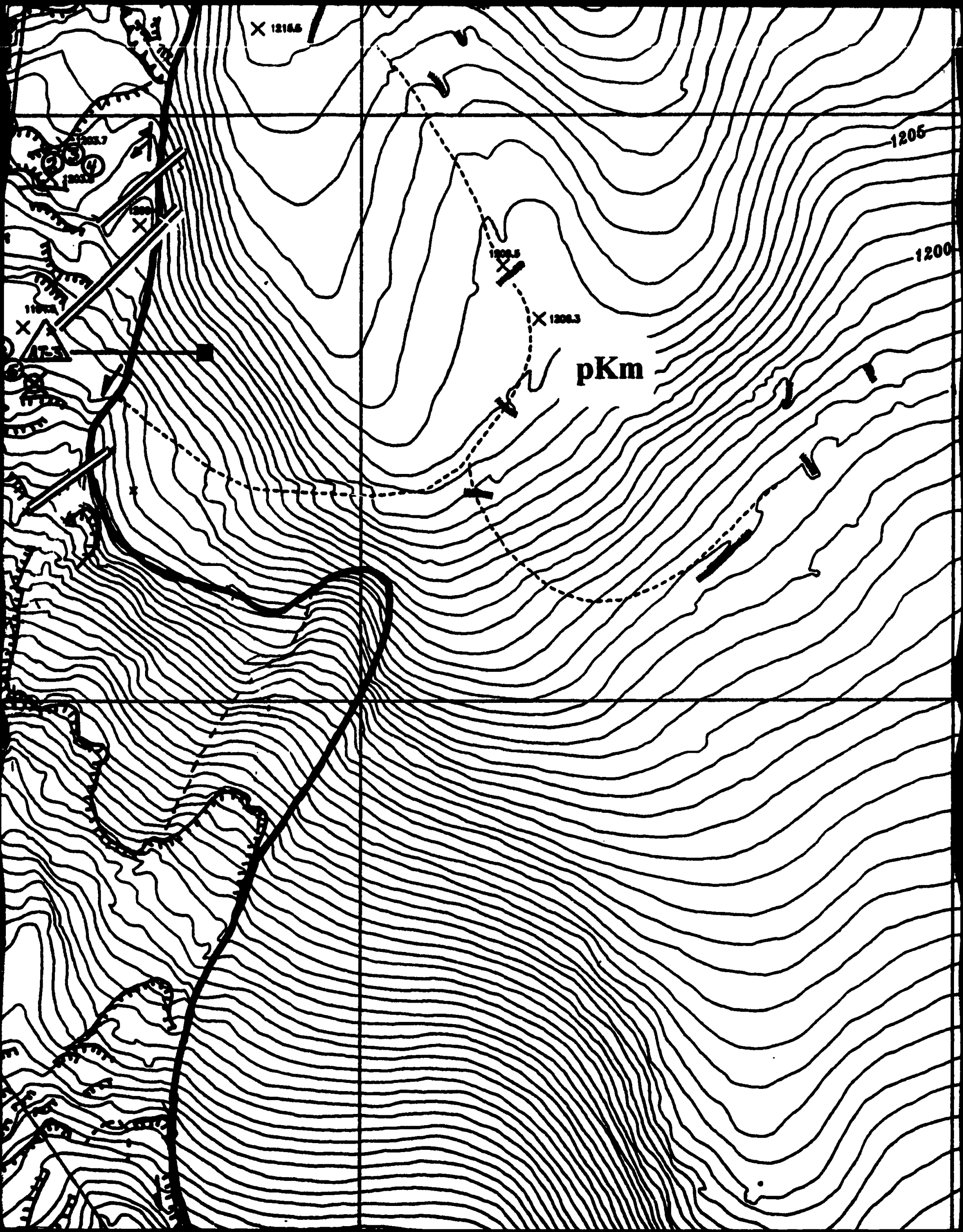


Paved Roads.

....... Maintained dirt roads and shoulders along paved roads.

Unimproved dirt roads and paths.

Boundary of failed material.

Boundary of area affected by landaliding.

Transit line used for the topographic profile.

Seismic aurvey line.

Power line.

Perennial stream.

Surface extensometers.

Topographic survey points (elevations in meters).

Monitoring equipment station.

Aerial photo targets.

Boring site.

Soil sample.

Berm.

Tree canopy.

Dip-allp symbol.

Direction of relative movement. 


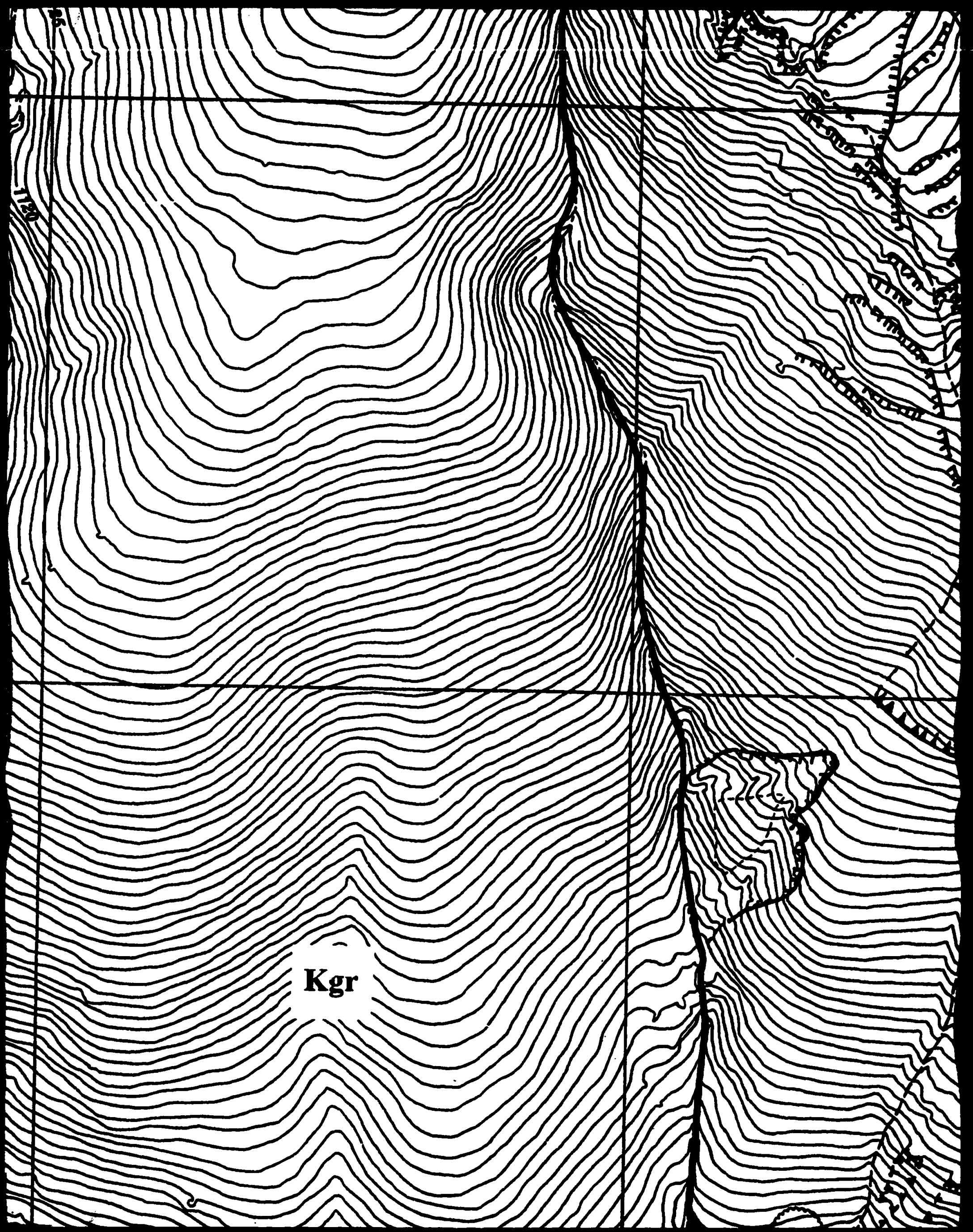




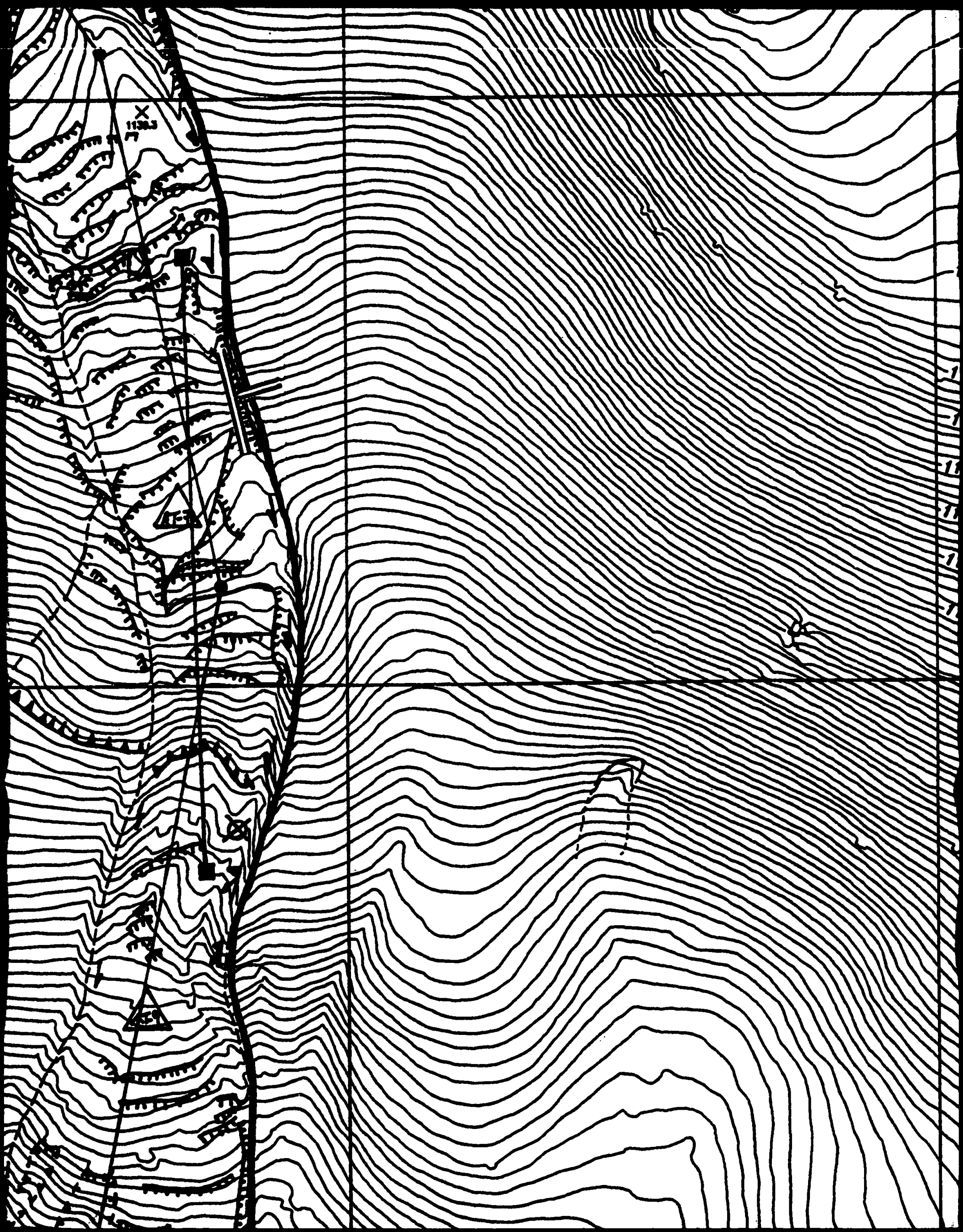




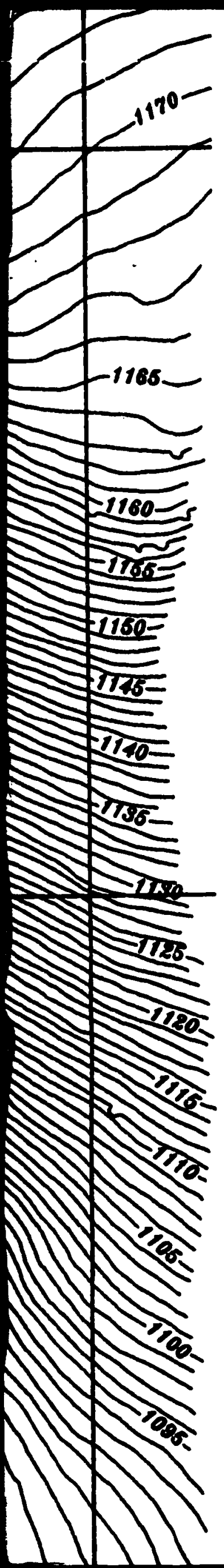

Geologic contact (approximate location)

Tm Mehrten Formation

Andesitic lahare

4. 10 my.

Ker Juraside/Cretaceous diorite

and quartz diorite

100 my and older.

$\mathbf{p} \mathbf{K m}$

Lower Paleozoic quartz

mica sechist of the Shoo Ply Complex.

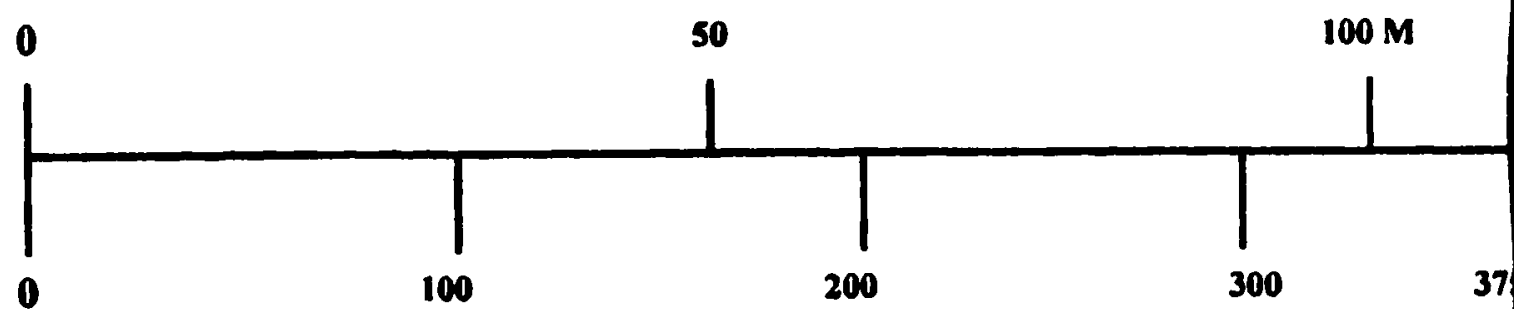

CONTOUR INTERVAL 1 METER (3.28 FEET)

This map has been modified by the author of this thesis. This map was made by the USGS Laborat for the Geologic Photogrammetry and Digital Mapping Department, Dover, CO. It was compiled in Aug 1997 from aerial photography flown at 1:3,600 nominal scale. All aero-triangulation and contour collect was performed by Jim Messerich of the USGS National Cooperative Geologic Mapping Program. Field control surveying was performed by Pam Borman of the USFS, Eldorado National Forest, CA. Aerial pho were flown on 15 Juls, 1997.

\section{GEOLOGIC PROPERTIES OF \\ THE CLEVELAND CORRAL LANDSLIDE, RIVERTON CALIFORNIA}

Nathan E. Berube 1999

\section{PLATE 1}




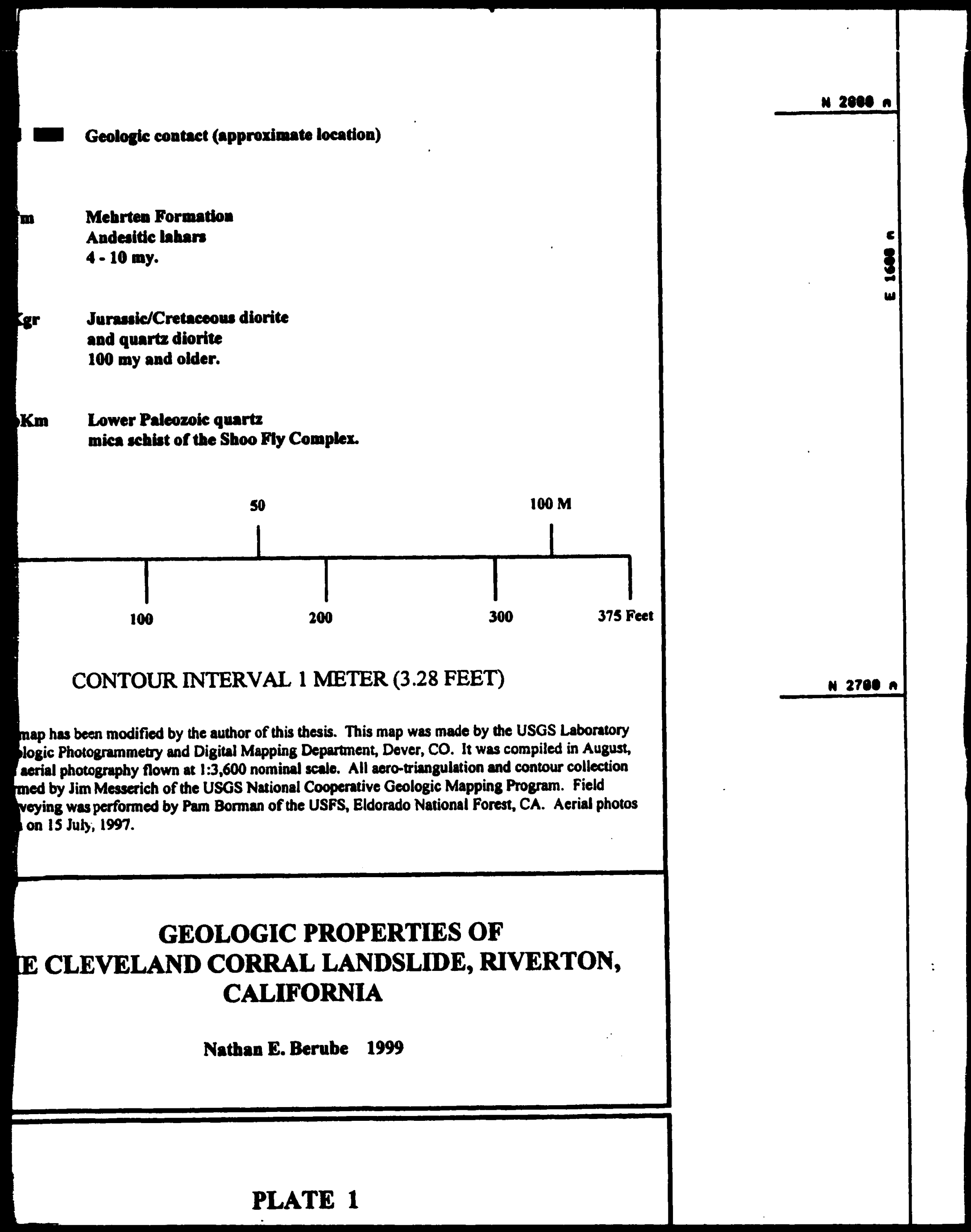




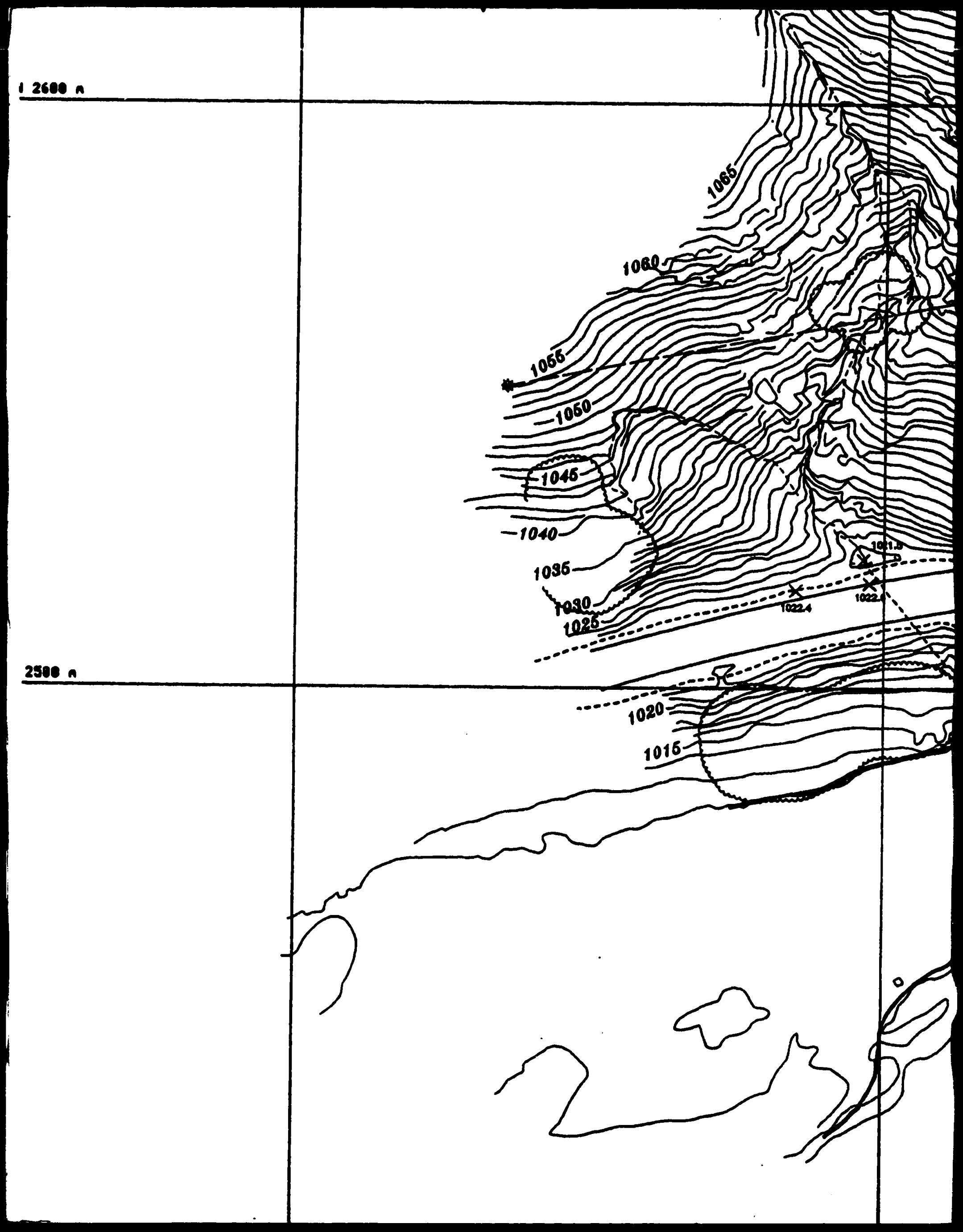




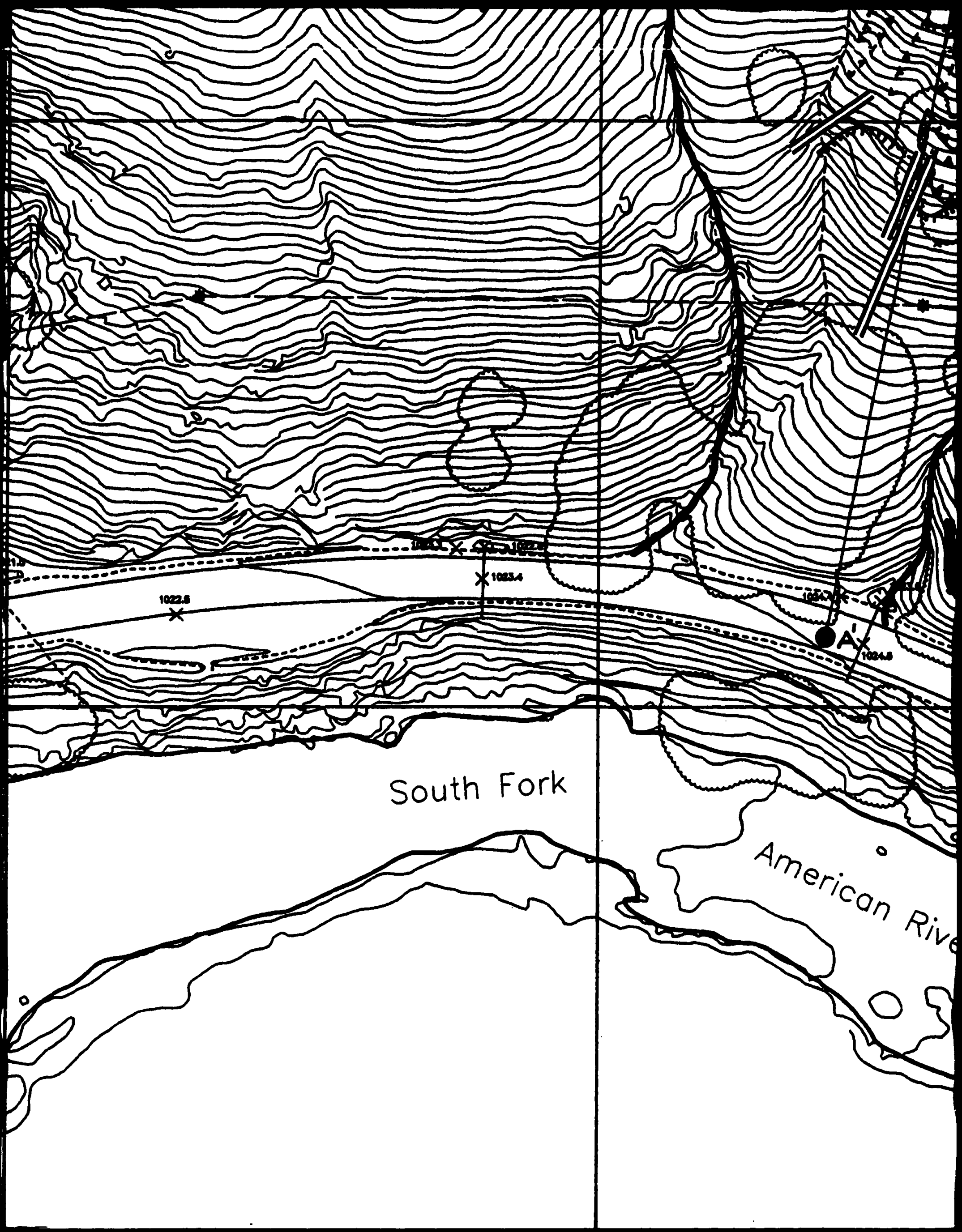




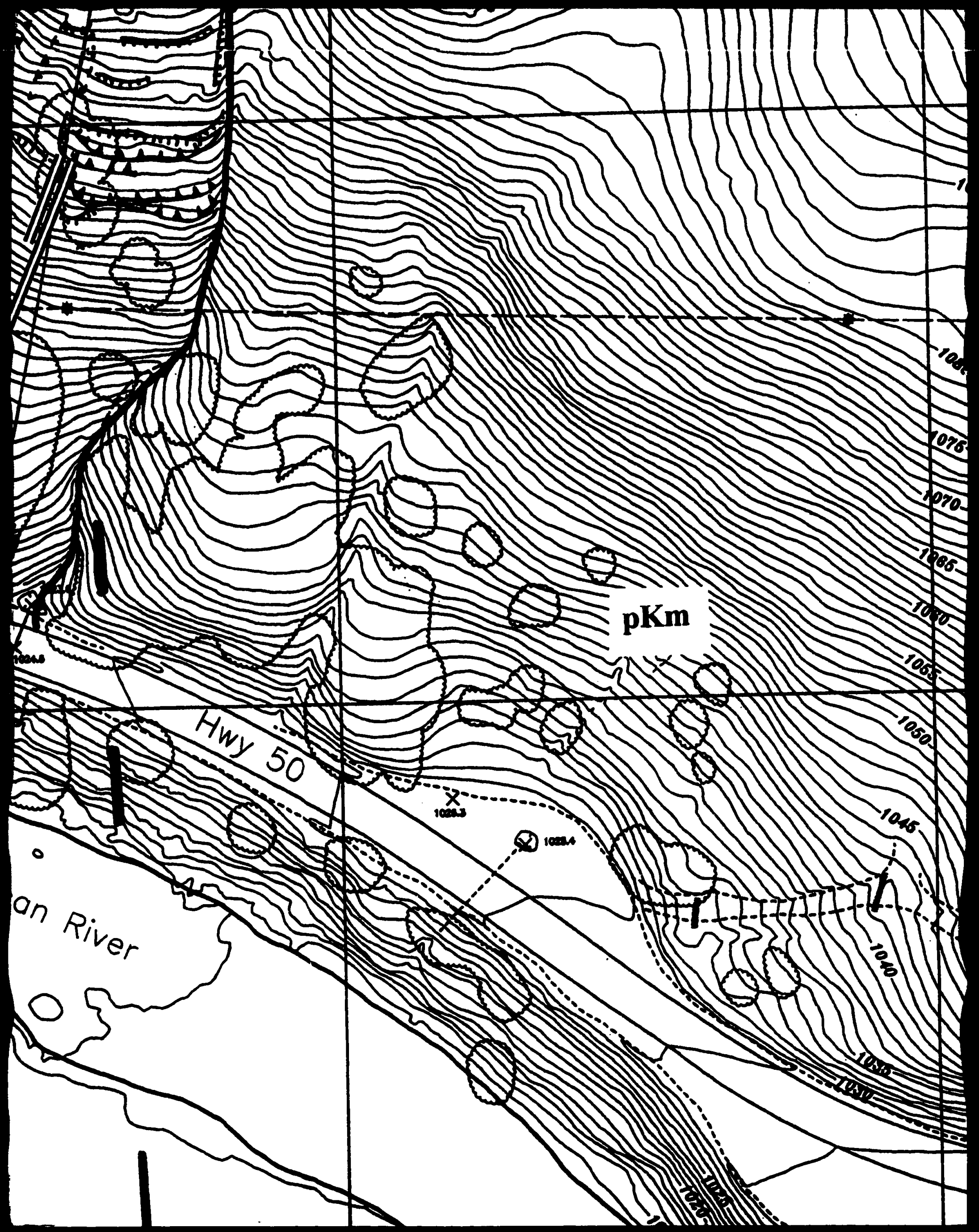




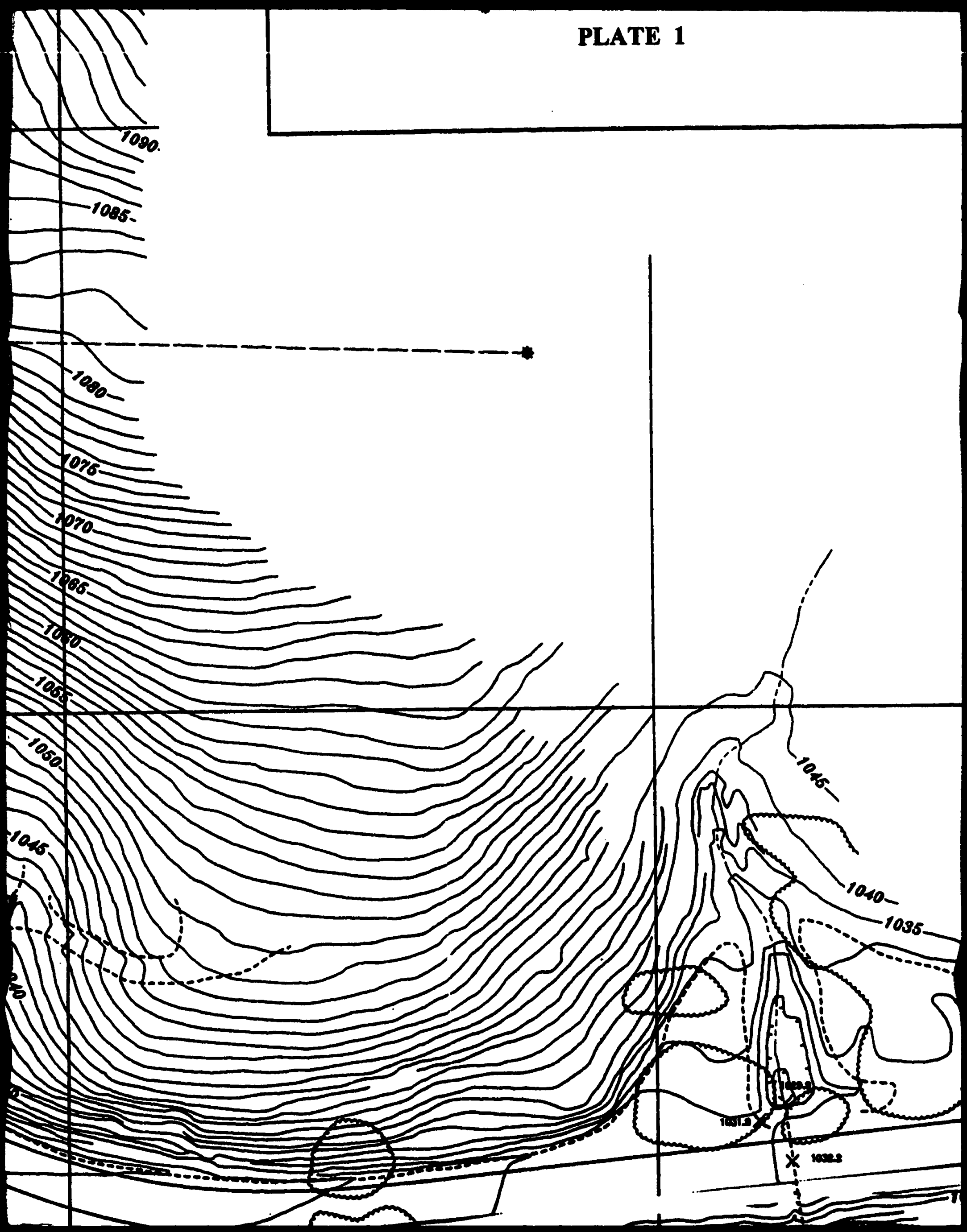




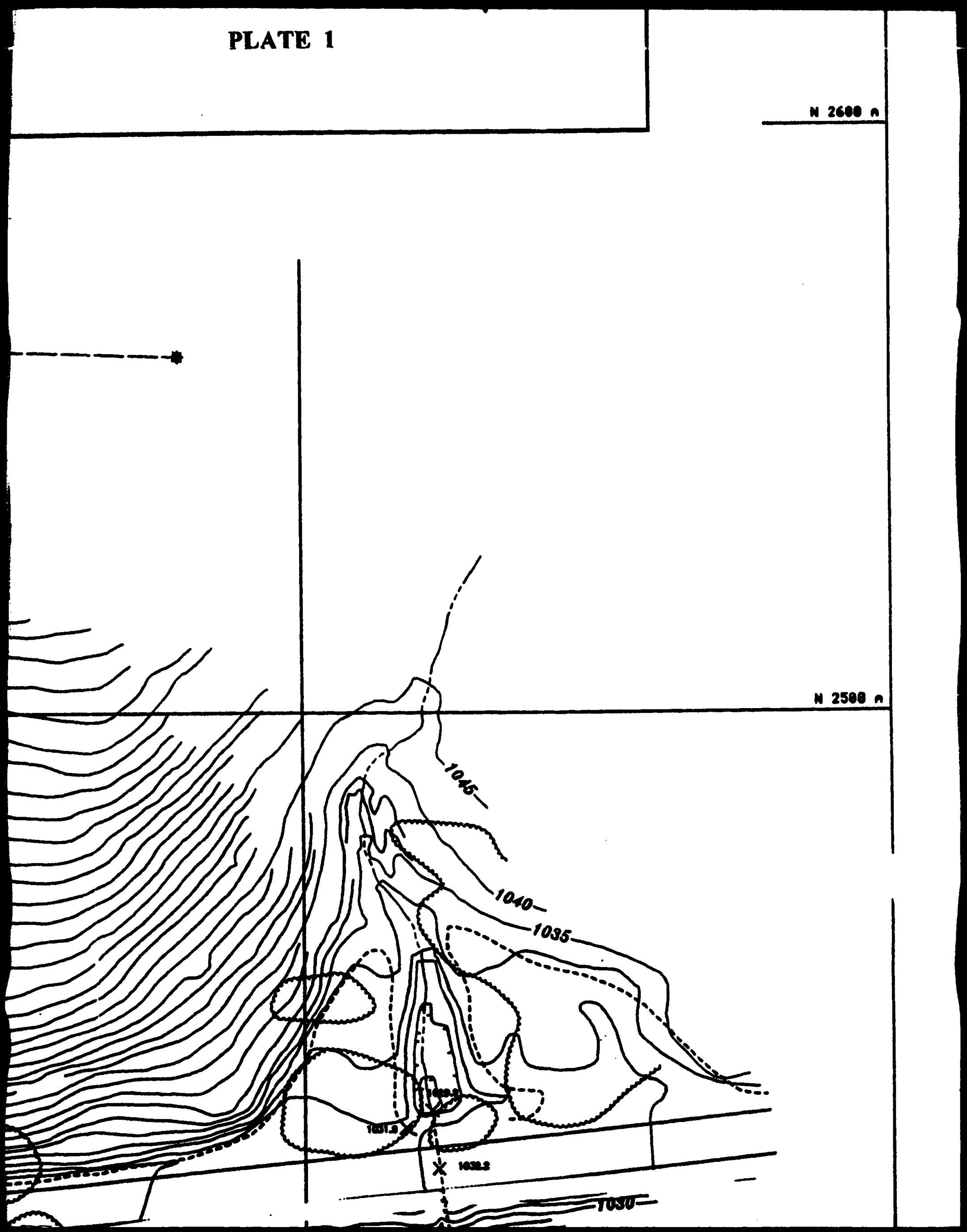




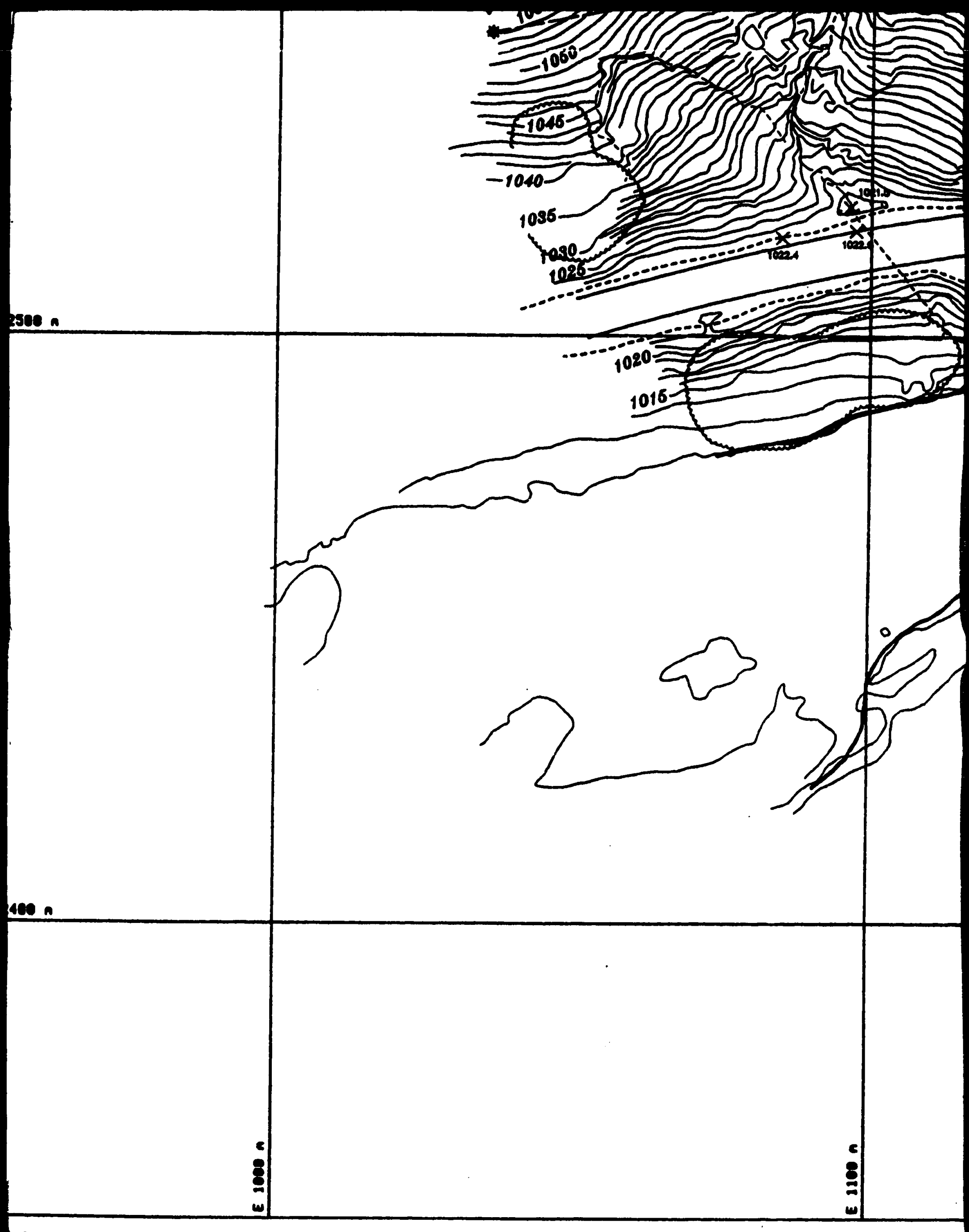




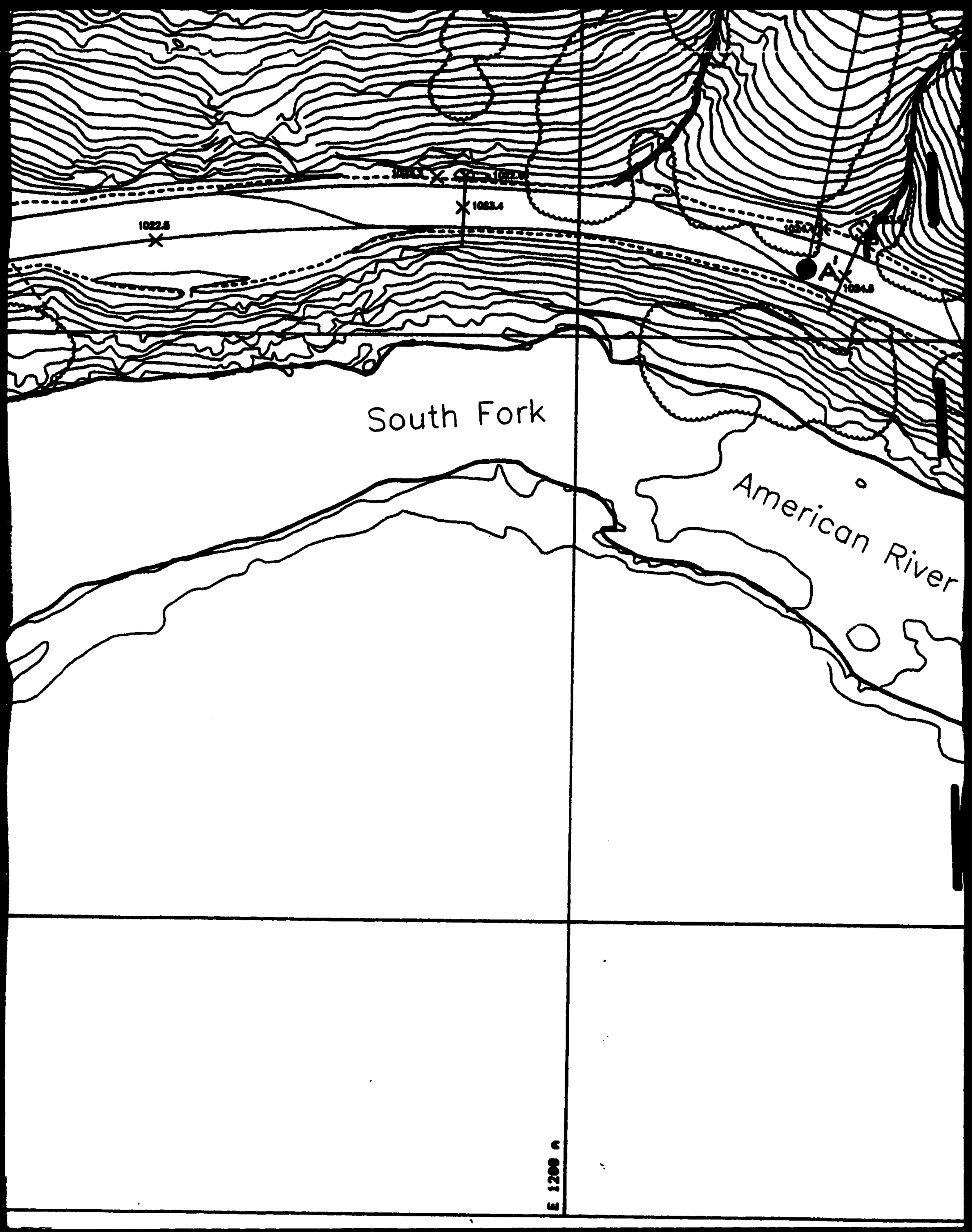


